\title{
COFIRING BIOMASS WITH LIGNITE COAL
}

Final Technical Report

For the period September 20, 2000, to December 31, 2001

Prepared for:

AAD Document Control

U.S. Department of Energy

National Energy Technology Laboratory

PO Box 10940

Pittsburgh, PA 15236

Cooperative Agreement No. DE-FC26-00NT40900

UND Fund 4521

Prepared by:

Darren D. Schmidt

Energy \& Environmental Research Center

University of North Dakota

Box 9018

Grand Forks, ND 58202-9018 


\section{DOE DISCLAIMER}

This report was prepared as an account of work sponsored by an agency of the United States Government. Neither the United States Government, nor any agency thereof, nor any of their employees makes any warranty, express or implied, or assumes any legal liability or responsibility for the accuracy, completeness, or usefulness of any information, apparatus, product, or process disclosed or represents that its use would not infringe privately owned rights. Reference herein to any specific commercial product, process, or service by trade name, trademark, manufacturer, or otherwise does not necessarily constitute or imply its endorsement, recommendation, or favoring by the United States Government or any agency thereof. The views and opinions of authors expressed herein do not necessarily state or reflect those of the United States Government or any agency thereof.

This report is available to the public from the National Technical Information Service, U.S. Department of Commerce, 5285 Port Royal Road, Springfield, VA 22161; phone orders accepted at (703) $487-4650$.

\section{ACKNOWLEDGMENT}

This report was prepared with the support of the U.S. Department of Energy (DOE) National Energy Technology Laboratory Cooperative Agreement No. DE-FC26-00NT40900. However, any opinions, findings, conclusions, or recommendations expressed herein are those of the authors(s) and do not necessarily reflect the views of DOE.

\section{EERC DISCLAIMER}

LEGAL NOTICE This research report was prepared by the Energy \& Environmental Research Center (EERC), an agency of the University of North Dakota, as an account of work sponsored by DOE. Because of the research nature of the work performed, neither the EERC nor any of its employees makes any warranty, express or implied, or assumes any legal liability or responsibility for the accuracy, completeness, or usefulness of any information, apparatus, product, or process disclosed, or represents that its use would not infringe privately owned rights. Reference herein to any specific commercial product, process, or service by trade name, trademark, manufacturer, or otherwise does not necessarily constitute or imply its endorsement or recommendation by the EERC. 


\title{
COFIRING BIOMASS WITH LIGNITE COAL
}

\begin{abstract}
The University of North Dakota Energy \& Environmental Research Center, in support of the U.S. Department of Energy's (DOE) biomass cofiring program, completed a Phase 1 feasibility study investigating aspects of cofiring lignite coal with biomass relative to utility-scale systems, specifically focusing on a small stoker system located at the North Dakota State Penitentiary(NDSP) in Bismarck, North Dakota. A complete biomass resource assessment was completed, the stoker was redesigned to accept biomass, fuel characterization and fireside modeling tests were performed, and an engineering economic analysis was completed. In general, municipal wood residue was found to be the most viable fuel choice, and the modeling showed that fireside problems would be minimal. Experimental ash deposits from firing 50\% biomass were found to be weaker and more friable compared to baseline lignite coal. Experimental sulfur and $\mathrm{NO}_{\mathrm{x}}$ emissions were reduced by up to $46 \%$. The direct costs savings to NDSP, from cogeneration and fuel saving, results in a $15-$ to 20 -year payback on a $\$ 1,680,000$ investment, while the total benefits to the greater community would include reduced landfill burden, alleviation of fees for disposal by local businesses, and additional jobs created both for the stoker system as well as from the savings spread throughout the community.
\end{abstract}




\section{TABLE OF CONTENTS}

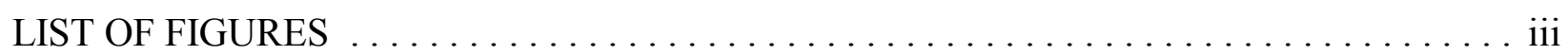

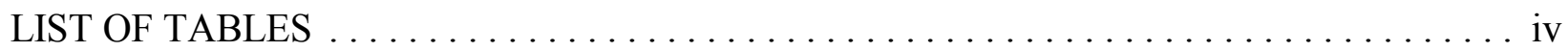

EXECUTIVE SUMMARY $\ldots \ldots \ldots \ldots \ldots \ldots \ldots \ldots \ldots \ldots \ldots \ldots \ldots \ldots \ldots \ldots \ldots$

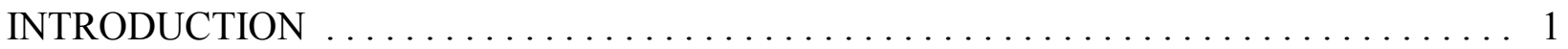

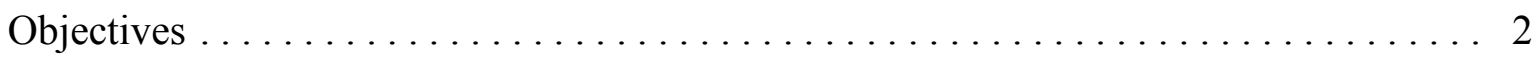

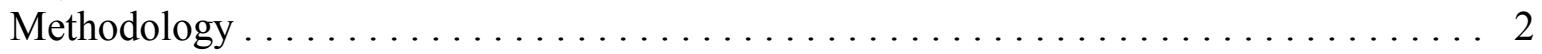

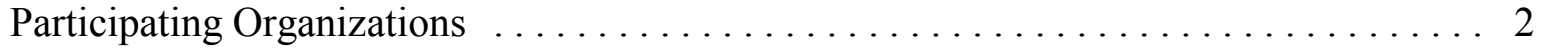

North Dakota State Penitentiary Background $\ldots \ldots \ldots \ldots \ldots \ldots \ldots \ldots \ldots \ldots \ldots$

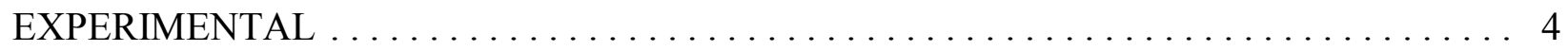

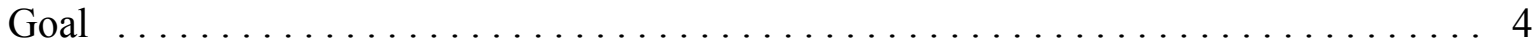

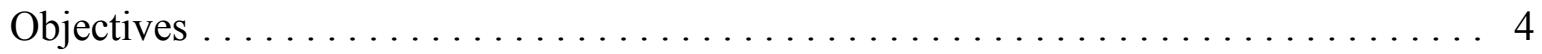

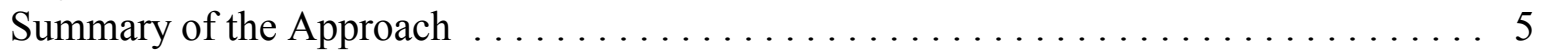

Task 1 - Local Biomass Resource Assessment .................... 5

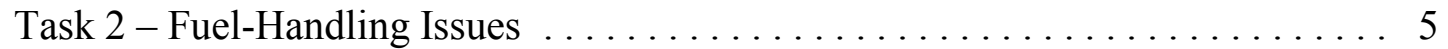

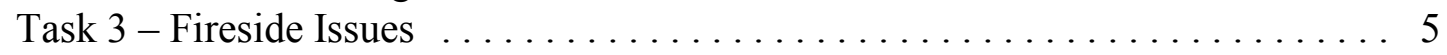

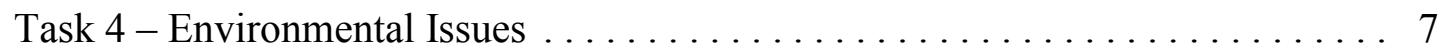

Task 5 - Energy Production Assessment $\ldots \ldots \ldots \ldots \ldots \ldots \ldots \ldots \ldots \ldots \ldots \ldots \ldots \ldots \ldots \ldots$

Task 6 - Engineering Economic Analysis $\ldots \ldots \ldots \ldots \ldots \ldots \ldots \ldots$

TASK 1 - LOCAL BIOMASS RESOURCE ASSESSMENT $\ldots \ldots \ldots \ldots \ldots \ldots \ldots$

Agricultural Processing Residues . . . . . . . . . . . . . . . . . . . . . . . . 10

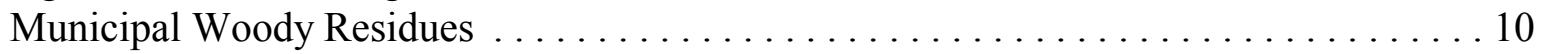

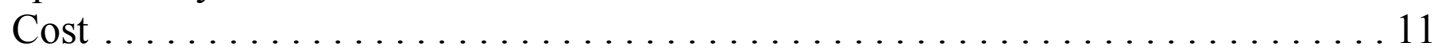

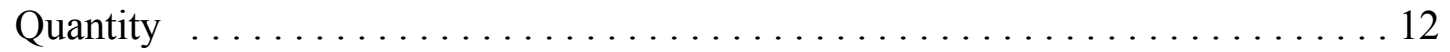

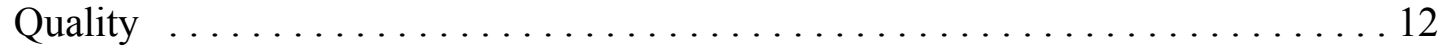

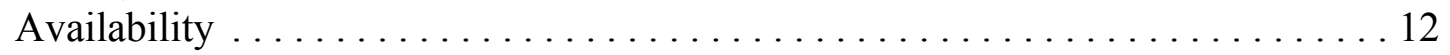

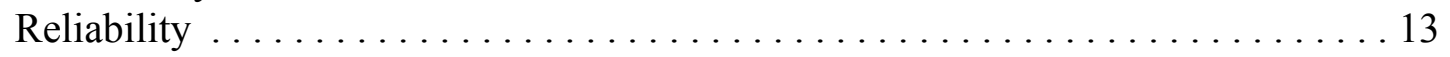

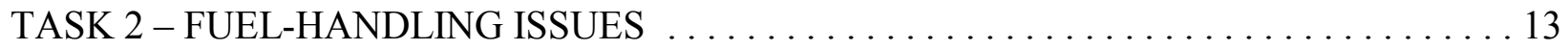

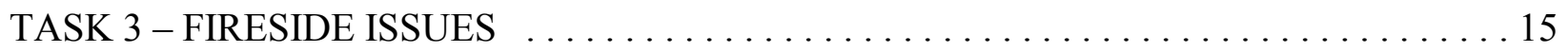

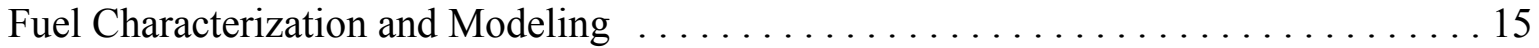

Introduction and Description of Samples and Analysis Data ............ 15

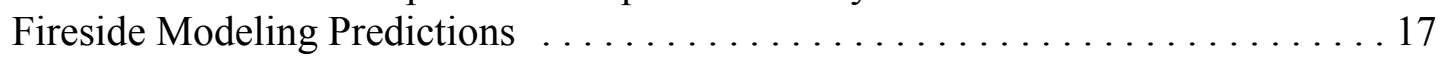

Equilibrium Thermodynamic and Viscosity Calculations $\ldots \ldots \ldots \ldots \ldots \ldots 21$

Continued... 


\section{TABLE OF CONTENTS (continued)}

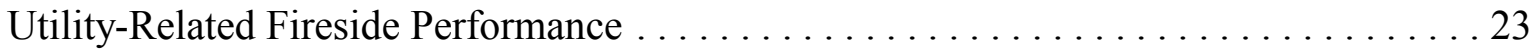

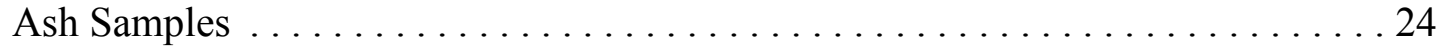

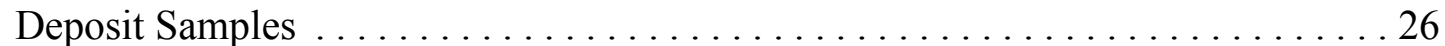

Clinkering Potential for Grate-Fired Systems $\ldots \ldots \ldots \ldots \ldots \ldots \ldots \ldots \ldots \ldots \ldots \ldots \ldots \ldots$

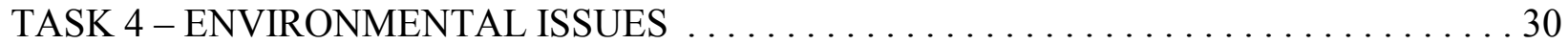

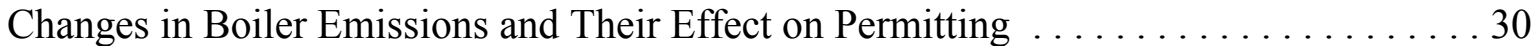

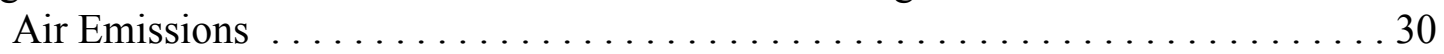

Required Air-Related Permit Actions . . . . . . . . . . . . . . . . . 31

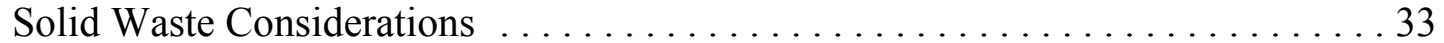

Water Quality/Storm Water Runoff . . . . . . . . . . . . . . . . . . . . 33

Transfer Station Permitting . . . . . . . . . . . . . . . . . 34

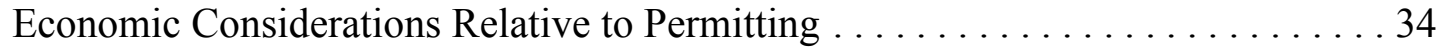

TASK 5 - ENERGY PRODUCTION ASSESSMENT . . . . . . . . . . . . . . . . 34

TASK 6 - ENGINEERING ECONOMIC ANALYSIS $\ldots \ldots \ldots \ldots \ldots \ldots \ldots \ldots$

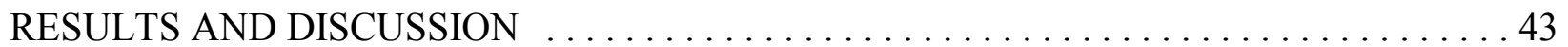

Task 1 - Local Biomass Resource Assessment . . . . . . . . . . . . . . . . . . 44

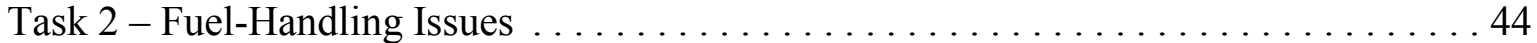

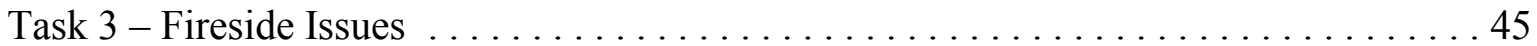

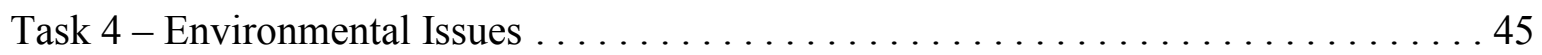

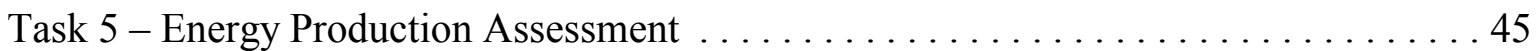

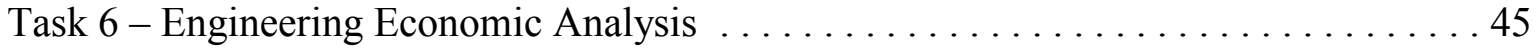

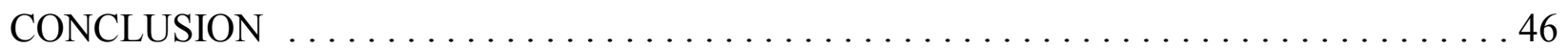

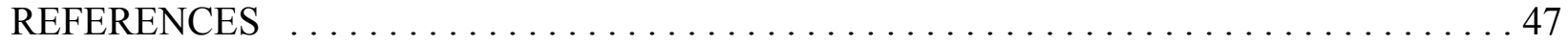

BIOMASS RESOURCES $\ldots \ldots \ldots \ldots \ldots \ldots \ldots \ldots \ldots \ldots \ldots \ldots \ldots \ldots \ldots \ldots \ldots$ APPENDIX A

EQUIPMENT SPECIFICATIONS $\ldots \ldots \ldots \ldots \ldots \ldots \ldots \ldots \ldots \ldots \ldots \ldots$ APPENDIX B

FIRESIDE DATA $\ldots \ldots \ldots \ldots \ldots \ldots \ldots \ldots \ldots \ldots \ldots \ldots \ldots \ldots \ldots \ldots \ldots \ldots \ldots \ldots$ APPENDIX C

ENERGY CALCULATIONS $\ldots \ldots \ldots \ldots \ldots \ldots \ldots \ldots \ldots \ldots \ldots \ldots \ldots$ APPENDIX D 


\section{LIST OF FIGURES}

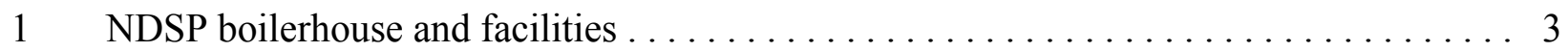

2 Counties within 100-mile radius of Bismarck, North Dakota $\ldots \ldots \ldots \ldots \ldots \ldots$

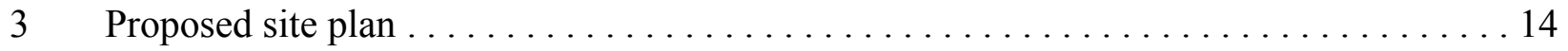

4 PCQUEST calculation results for various lignite and tree wood blends $\ldots \ldots \ldots \ldots 20$

5 PCQUEST calculation results for various lignite and wood chip blends . . . . . . . . 20

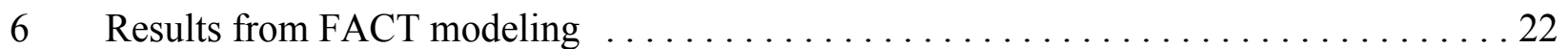

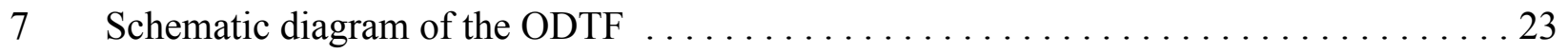

8 Particle-size distribution for fly ash from lignite, lignite-tree wood, and lignite-wood chips determined by CCSEM . . . . . . . . . . . . . . . . . . . . . . . . . 25

$9 \quad$ SEM micrograph of a deposit formed from Beulah lignite $\ldots \ldots \ldots \ldots \ldots \ldots \ldots 27$

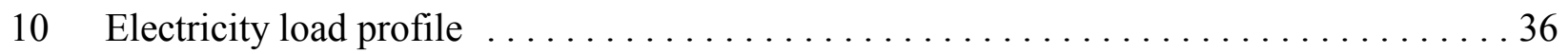

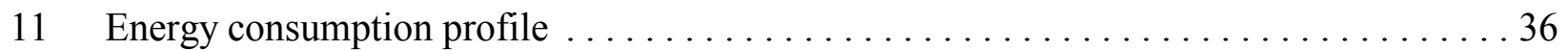

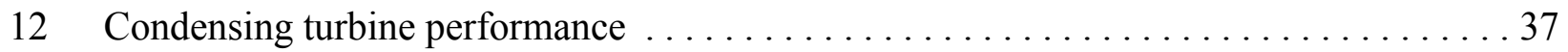

13 Energy production model, process flow diagram $\ldots \ldots \ldots \ldots \ldots \ldots \ldots \ldots \ldots \ldots$

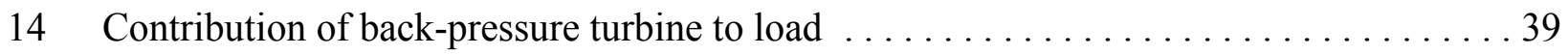

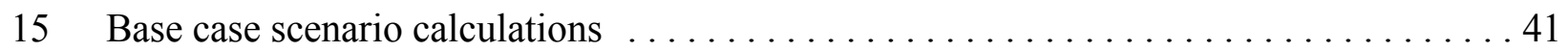

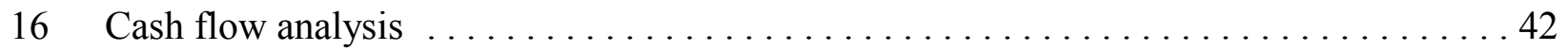

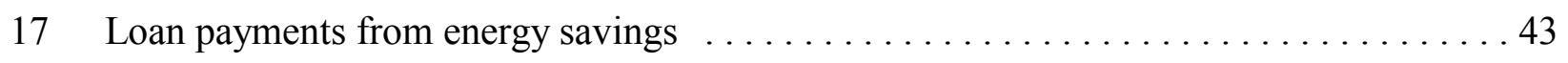

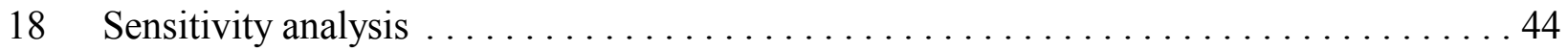




\section{LIST OF TABLES}

1 Theoretically Available Biomass Within 100-mile Radius of Bismarck

2 Theoretical Quantities of the Most Promising Biomass Resources Within 100-mile

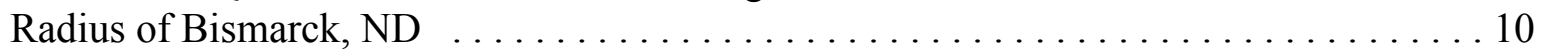

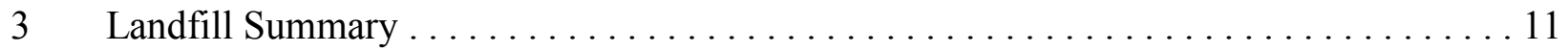

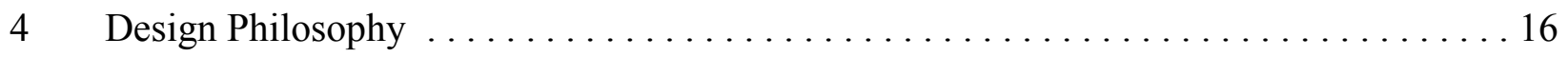

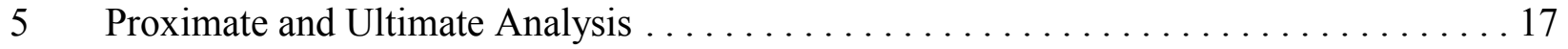

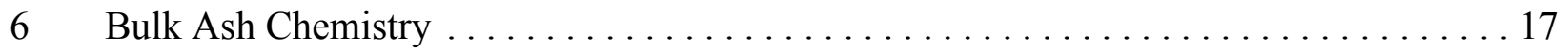

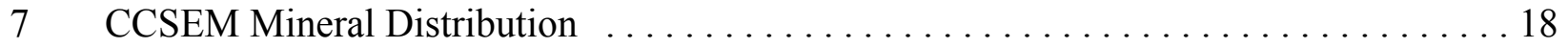

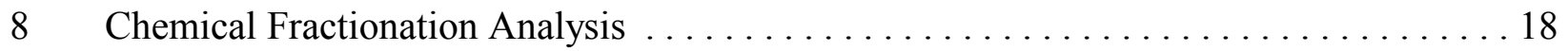

9 Results of CCSEM Analysis on Fly Ash from Lignite, Lignite-Pallet Wood, and

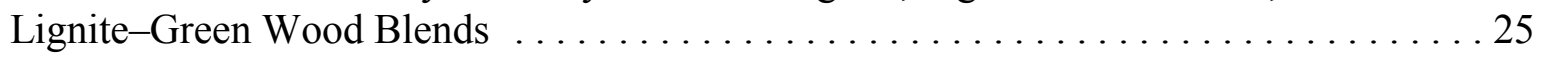

10 Results of SEMPC Analysis on Deposits from Lignite, Lignite-Pallet Wood, and

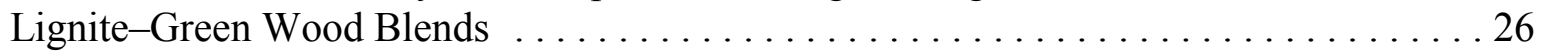

11 Lignite Deposit Morphology Analysis Results . . . . . . . . . . . . . . 27

12 Emission Estimates for Given Blends from the State Correctional Center . . . . . . . . 32

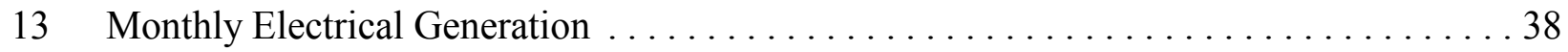

14 Monthly Average Peak Thermal Load Case . . . . . . . . . . . . . . . . . 38

15 Relative Payback Analysis for the Back-Pressure Turbine . . . . . . . . . . . . . . . . 39 


\section{COFIRING BIOMASS WITH LIGNITE COAL}

\section{EXECUTIVE SUMMARY}

In support of the U.S. Department of Energy's (DOE) biomass cofiring program, the University of North Dakota Energy \& Environmental Research Center (EERC) completed a Phase 1 feasibility study investigating the aspects of cofiring lignite coal with biomass relative to utility-scale systems and, specifically, for a small stoker system located at the North Dakota State Penitentiary (NDSP) in Bismarck, North Dakota.

A complete biomass resource assessment led to the selection of municipal wood residue as the most viable fuel choice in terms of quantity, cost, quality, availability, and reliability. Wood residues can be delivered to the NDSP facility from tree service and municipal haulers at no cost per ton, avoiding a $\$ 10.00$ per ton tipping fee at the landfill and an unnecessary landfill burden. The fuelhandling design includes a complete receiving station, with segregation, grinding, and drying capability. Modifications to the stoker include dual-fuel Detroit stokers and a vibratory grate. Fireside issues were addressed by completing fuel characterization, modeling of fireside behavior, test burns relative to utility-scale systems, and grate-fired testing to evaluate clinker formation. In general, all results indicated that fireside issues would be minimal and decrease in severity with increased blending of biomass with lignite coal. Specifically, despite the increased percentage of $\mathrm{Ca}$, $\mathrm{K}$, and $\mathrm{P}$ in biomass ash, the lower amounts of ash resulted in experimental tube fouling deposits that were more friable and weaker in strength. Modeling results were in agreement with experimental results. Measured emissions from 50\% blends indicated decreases in sulfur and $\mathrm{NO}_{\mathrm{x}}$ at $46 \%$ and $33 \%$, respectively. Clinker formation from biomass blended at $75 \%$ with coal was minimal to nonexistent. Environmental permitting will require minimal modification to an existing air permit for NDSP and in no way affects the economics of the project. Cogeneration of electricity, in combination with fuel cost savings, produces a 15 - to 20 -year payback on a $\$ 1,680,000$ investment. These are the direct costs to the NDSP facility and do not take into account the much larger benefits to the community that are obtained by utilizing biomass residues.

The specific benefits of this project are outlined below, and the benefits realized from the support of the DOE biomass cofiring program are summarized. The NDSP, through the results of this study, has the potential to move forward with a cofiring application that can achieve the following for the local community and the facility:

- Reduced sulfur and $\mathrm{NO}_{\mathrm{x}}$ emissions and zero net gain of carbon dioxide

- Reduction of landfill burden and associated taxpayer costs

- Alleviation of tipping fees for disposal from local businesses

- Additional jobs at NDSP, and potentially other businesses, benefiting from lower disposal costs 
- Reduction in energy costs, which will benefit taxpayers in the long term

- Increased energy reliability and security

- No significant change to the NDSP air quality permit

- 15- to 20-year return on investment

In many cases, the infrastructure and market conditions are available to take advantage of cofiring biomass; however, various factors inhibit the progress for biomass utilization. DOE's support helps to overcome barriers resulting in viable projects that would not move forward otherwise. This project is a case in point, and the following barriers addressed by this study are outlined as follows:

- District energy systems, approximately 5800 of them throughout the United States, provide an appropriately sized infrastructure for utilizing biomass. The primary concern for facility managers is usually a consistent supply of energy. Cost is secondary. State-funded institutions provide very limited incentives to lower energy costs through investigation of alternative fuels or fuel diversification. This forces facility managers to focus budget justification efforts on maintenance upgrades as opposed to exploring nontraditional solutions to lower costs. DOE-funded studies can help facility managers see specific cases that could reduce costs by cofiring biomass.

- Biomass is site-specific, case-specific, and nontraditional. These attributes create greater difficulty evaluating biomass relative to fossil fuels. Typical energy-related engineering firms realize the technical and market difficulties of biomass and tend to focus on more reliable, profitable fossil energy solutions. The result is a low availability of off-the-shelf equipment and knowledge of how to take advantage of biomass fuels. Compared to fossil energy, significant work must be done to verify biomass resource availability prior to implementation, since biomass may come from a variety of sources. DOE-funded studies help to alleviate the effort of resource evaluation by employing knowledgeable research facilities. Resulting case studies help to demonstrate how to seek available resources and provide detailed information on equipment that is unique for biomass applications.

- Potential biomass fuel suppliers are not significant drivers of the market and do not have the benefit of the infrastructure of fossil fuels. Natural gas and coal are brokered commodities made available from the supplier and marketed to a target audience. The industries have been well developed over time and operate at peak efficiencies to provide competitive costs. Biomass, a relatively immature industry, lacks procurement efficiency. Many potential fuel suppliers pay to dispose of material or have found some low-valueadded markets for residues. Small businesses that generate wood residues do not have the resources to collaborate and convince energy users to utilize their waste. The DOE's support of this study helped to link the generators of waste material to an energy consumer. 


\section{COFIRING BIOMASS WITH LIGNITE COAL}

\section{INTRODUCTION}

The U.S. Department of Energy (DOE) cofiring program released solicitation DE-PS2600NT40775 on February 23, 2000, to support cost-shared applications for research and development of technologies for cofiring biomass feedstocks with fossil fuels. The interest on behalf of DOE was for five critical areas of research:

- Biomass cofiring as an emission reduction technique

- Gasification-based cofiring strategies

- Closed-loop biomass cofiring

- Low-rank coal cofiring - subbituminous and lignite

- University and college cofiring applications

This project represents support of activities under low-rank coal cofiring. The justification on behalf of DOE for funding this area of research, as taken from the solicitation, is as follows. "The DOE has, in the past, cooperated with power producers in testing and analyzing biomass cofiring in coal-fired boilers that use bituminous and some subbituminous coals. However, the program has not tested cofiring biomass in a lignite-fired boiler or extensively demonstrated subbituminous coals. Through this subtopic, the biomass cofiring program intends to add lignite and subbitumionous coals to the fossil fuels being demonstrated in other projects. The United States has a significant resource base of these fuels. Cofiring of lignite with biomass can be significantly different than cofiring subbituminous or bituminous coals because of the ash chemistry and moisture and other factors. A potentially attractive feature of cofiring biomass with lignite is that the boilers are designed for a fuel with low heat and high moisture content that is consistent with the properties of biomass. As such, DOE is seeking, through this solicitation, to demonstrate the viability of cofiring biomass with lignite or subbituminous coal for application within the fossil-fuel industry."

As part of typical business activity, the Energy \& Environmental Research Center (EERC) contacted various local lignite- and subbituminous-fired utilities. Very little interest could be found among the commercial sector in funding a project. The EERC did, however, get significant interest from smaller users of lignite coal. The EERC was able to respond to the solicitation with a proposal to demonstrate cofiring biomass with lignite coal. The research project was designed to provide data to both utility-scale and small-scale systems. The DOE highlights under Subtopic E how small-scale, typically stoker-fired systems, are more likely to adapt to the use of biomass fuels. This project was performed to provide a feasibility study to a small stoker-fired system, conduct experimental combustion research, and proceed with a Phase 2 demonstration of the small stoker system to extrapolate data to large-scale utilities. The project achieves multiple objectives set forth by DOE and represents an excellent economical demonstration of biomass fuel use. 


\section{Objectives}

The overall objectives of the project are to complete a technical and economic feasibility study on cofiring wood waste with lignite at the North Dakota State Penitentiary (NDSP), obtain the first research data on the impact of cofiring biomass fuels with lignite coal, provide a demonstration to other state institutions and small stoker-fired systems, and provide research data for lignite utilities.

\section{Methodology}

This project provides the opportunity to explore the cofiring of biomass with lignite coal. Factors such as the dispersion of resources and the physical properties of biomass can make biomass fuel expensive to transport, handle, and feed into conventional systems. While the economics may not justify cofiring biomass at large-scale utility plants, smaller facilities, which may be located close to biomass resources and pay a higher price for coal, can economically justify using biomass as a fuel. Additionally, these smaller facilities provide a unique opportunity to learn about the properties and benefits of cofiring biomass with lignite. Basic research and demonstration at the smaller scale are applicable to larger utility systems. This project provides a case study for the estimated 5800 district energy systems throughout the United States and provides a jump-start for lignite utilities, when future developments improve the economics for cofiring biomass.

The EERC discovered a unique opportunity existing in Bismarck, North Dakota. The NDSP is interested in reducing the cost of operation of its lignite-fired steam plant. The City of Bismarck currently landfills 13,000 tons/yr of combustible wood residue. By cofiring biomass with lignite, NDSP can potentially convert its existing steam heat plant from a 2800-ton/yr, 7-month operation to a year-round steady-load cogeneration facility that would operate at a net profit. Considering the monetary value of environmental costs associated with clean air and landfilling, the benefit of the proposed project is equal to $\$ 854,000$ annually. This exciting opportunity benefits the landfill, city government, the penitentiary, state government, and the biomass and lignite coal industries and meets DOE objectives. The project demonstrates how other similar facilities could use biomass to improve the cost-effectiveness of their operation and possibly increase the use of local biomass resources and lignite coal.

\section{Participating Organizations}

Participating organizations included the EERC, Grand Forks, North Dakota; the North Dakota Department of Corrections and Rehabilitation, Bismarck, North Dakota; the North Dakota Division of Community Services (DCS), Bismarck, North Dakota; King Coal Furnace Corporation, Bismarck, North Dakota; and K.J. Schwartz Engineering (KJSE), Bismarck, North Dakota. This project was made possible by funding from DOE's National Energy Technology Laboratory and cost share provided by DCS and the North Dakota Department of Corrections and Rehabilitation.

\section{North Dakota State Penitentiary Background}

Shown in Figure 1, NDSP is one of four prison divisions in North Dakota under the Department of Corrections. Located in East Bismarck, NDSP is the main prison complex and houses 


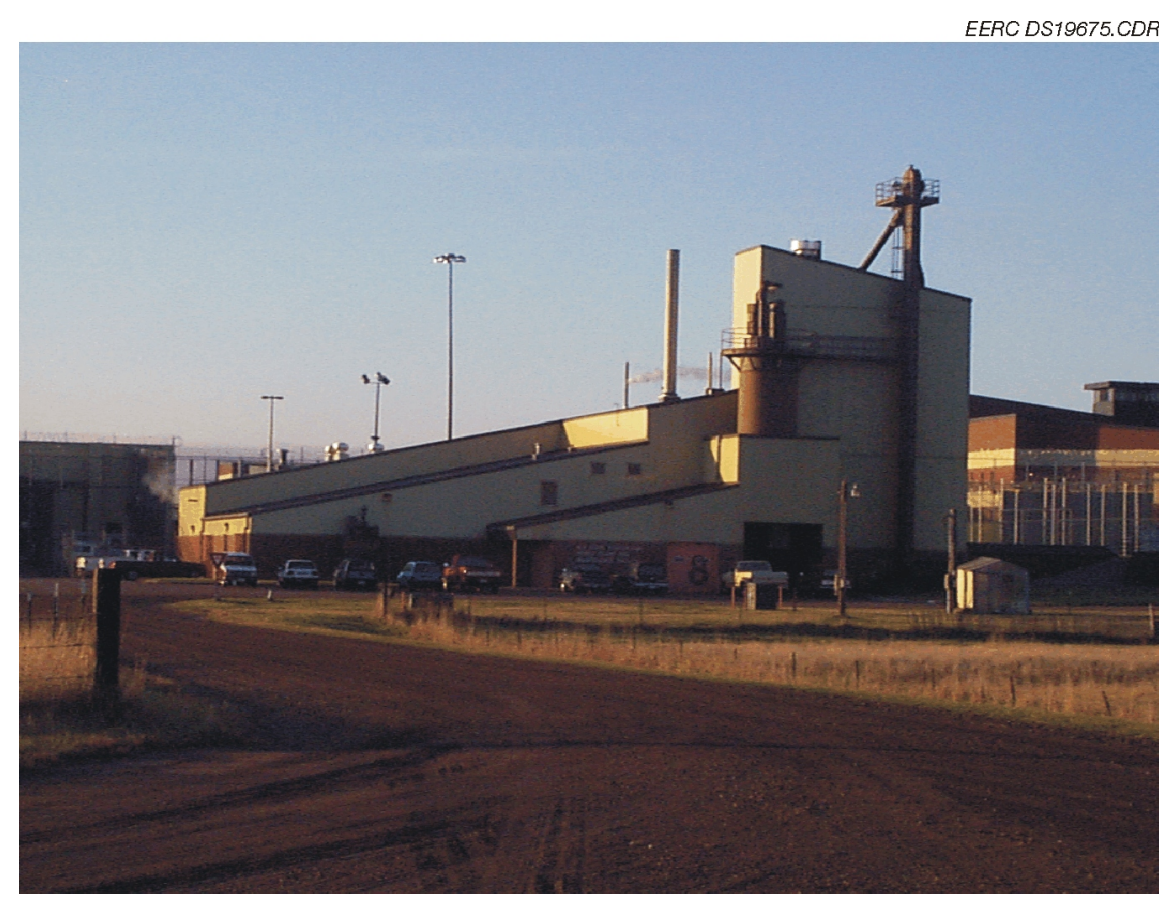

Figure 1. NDSP boilerhouse and facilities.

715 maximum to minimum high-custody inmates representing $68 \%$ of the state's inmate population. The facility covers 400,000 square feet of building space, and 180 acres of ground. Currently, the NDSP uses 2600 to 2800 tons/yr of lignite coal to provide steam heat to its facility. The steam is produced by a Zurn Industries boiler installed in 1982. The boiler is fed by a spreader stoker and removes ash with a dump grate. Steam is produced at $100 \mathrm{psig}$, saturated. The boiler has the capacity to produce $200 \mathrm{psig}$ at $28,000 \mathrm{lb} / \mathrm{hr}$ and operates at an efficiency of about $72 \%$. The fuel currently being fired is 2 -in. stoker coal with $34 \%$ moisture, $6 \%$ ash, $43 \%$ carbon, $3 \%$ hydrogen, $0.3 \%$ sulfur, $0.7 \%$ nitrogen, $13 \%$ oxygen, and $7240 \mathrm{Btu} / \mathrm{lb}$. The boiler operates 7 months out of the year, with shutdown May through October. The annual cost of operation is approximately $\$ 48,000 / \mathrm{yr}$, firing about 2600 tons $/ y r$ at $\$ 18.50 /$ ton. The boiler is fitted with an electrostatic precipitator (ESP) and backed up with two gas boilers.

Prior to the project, some prefeasibility work was completed to conceptualize a possible cofiring scenario at the penitentiary facility. A case was run assuming the penitentiary could collect a $\$ 10 /$ ton tipping fee for biomass, as the local landfill requires the same amount. At this rate, even a modest cogeneration system $(250 \mathrm{~kW})$ would provide a very attractive return on investment. However, as we moved forward into the project, we found that tree service companies and waste haulers would only haul direct to the NDSP if a $\$ 0 /$ ton rate were available. This changed the economics and engineering focus to come up with a system that could achieve an attractive rate of return based on offsetting fuel and electricity costs for the NDSP at $\$ 20 /$ ton and $\$ 0.05 / \mathrm{kWh}$ respectively. During prefeasibility work, we found that the Bismarck Landfill (located just down the road from the NDSP) was receiving at least 5000 tons/yr of usable wood fuel. Further efforts found twice the wood resource locally available to justify the project. In order to create a positive 
impression of our research results and sustain a useful demonstration for Phase 2, we considered attractive economics to be paramount in our Phase 1 efforts.

All inmates are sentenced to the Department of Corrections and Rehabilitation and are expected to work during their incarceration. Projects performed at NDSP provide rehabilitative benefits of holding a job and instilling the work ethic. Job assignments include janitorial, grounds maintenance, food services, laundry, property, and Rough Rider Industries (RRI). The Job Placement Committee coordinates the assignment of inmates to various jobs with the individual work supervisors. Inmates are expected to work 8 hours a day and are paid a daily wage for every day they work.

RRI is the industrial work program for the Prisons Division. The purpose of this program is to give inmates the opportunity to be productive with their time through meaningful work experience. Inmates who make an honest effort to address their treatment and education needs and fill their remaining time with meaningful work have been far more successful in staying out of prison once they are released. It is for this reason that compliance with treatment and education, as well as exhibiting proper behavior, are requirements to work at RRI. At NDSP, RRI has a furniture and upholstery factory, a sign shop, a license plate shop, and a metal factory. This project will result in jobs for inmates to support a biomass-receiving station with general operation and maintenance activities.

\section{EXPERIMENTAL}

\section{Goal}

The EERC, working with King Coal Furnace Corporation and KJSE, is providing a feasibility study and demonstration project that will provide scientific information on the cofiring of biomass with lignite coal and lead to a successful commercial application for the North Dakota Department of Corrections and Rehabilitation's penitentiary facility.

\section{Objectives}

- Complete analysis to determine the technical and economic feasibility of cofiring biomass fuels at NDSP's lignite-fired steam plant. The analysis will include assessment of local biomass resources in terms of quantity, preparation requirements, and delivered costs; design of a biomass cofeed system; evaluation of fireside performance; evaluation of design modifications required for cofiring; evaluation of environmental issues; reassessment of land/energy demand; and economic analysis.

- Complete bench-scale testing to provide data to DOE on cofiring biomass with lignite to support technical and economic decisions.

- Demonstrate to other state institutions and users of stoker-fired systems the performance and potential economic and environmental advantages of cofiring biomass with lignite. 
- Demonstrate at a smaller scale the cofiring of biomass with lignite and how it applies to utilityscale systems.

\section{Summary of the Approach}

The proposed project involves two phases. A Phase 1 feasibility study would determine the technical and economic feasibility of cofiring biomass at the NDSP and scientifically evaluate cofiring biomass and lignite through bench-scale studies. A Phase 2 demonstration project would make a documented case study available to other institutions, small stoker systems, and lignite utilities that are considering cofiring biomass. Research data would be collected during both phases to quantify the effects of several lignite-biomass mixtures.

Tasks were designed to carry out the above objectives and are described below:

\section{Task 1 - Local Biomass Resource Assessment}

The focus of this task was to assess local biomass resources, their availability, quantities, ease of access, and delivered projected cost. The EERC has developed a method for generating quantities of potential collectible biomass resources pertaining to small power systems. This estimating method, based on documented resources for wood residuals, agricultural residuals, animal waste, sludge, and municipal solid waste (MSW) was used to get a broad picture of the potential resource within 100 miles of the site. Other specific resources were identified and evaluated for use. All costs associated with preparation and handling were taken into consideration prior to selecting the most appropriate biomass cofiring resource.

\section{Task 2 - Fuel-Handling Issues}

Technical issues related to fuel-handling transportation, storage, drying, size reduction, metering, and feeding were addressed. This task in combination with Task 1 addressed costs for various fuel preparation methods. A direct comparison of systems was used to select the most economical and technically viable solution for handling and feeding biomass fuel. A complete system design and preliminary equipment specification were developed.

\section{Task 3 - Fireside Issues}

The focus of the task was to address technical and operational issues related to biomass cofiring combustion, such as needed residence time for complete combustion, slagging, fouling, corrosion, heat rate, efficiency, and steam production rates. Preliminary bench-scale tests were performed to assist in evaluation of these issues.

The primary objectives of the small-scale testing were as follows:

- To fully characterize the inorganic and ash-forming constituents of the lignite and wood biomass fuels that will be part of this program using conventional and advanced analytical techniques. 
- To determine the fundamental ash behavior and ash interactions between inorganic components in the lignite and biomass during combustion using small-scale combustion testing facilities and predictive modeling.

- To determine the overall fireside performance of $100 \%$ lignite compared to a blend of $20 \%$ or more of wood biomass with lignite, which included, at a minimum, determining fouling, slagging, grate clinkering, and fine-particulate generation levels under varied combustion conditions.

- To assess air toxic emissions for the lignite-biomass blends, including $\mathrm{NO}_{x}, \mathrm{SO}_{\mathrm{x}}$, mercury, and other significant trace elements.

- To make suggestions as to proper boiler design and operation, possibly including fuel preparation and feeding, air distributions, and deposit removal systems to maximize fireside boiler performance.

\section{Analysis}

One lignite sample and the two most common types of waste wood that could be supplied to the NDSP were acquired for analysis and combustion testing. The fuels were analyzed to fully characterize the inorganic and ash-forming constituents using conventional techniques and advanced techniques. Each sample received was submitted for analysis of particle size, bulk density, particle density, heating value, proximate-ultimate analysis, chlorine, major oxide chemistry (i.e., $\mathrm{SiO}_{2}$, $\mathrm{Fe}_{2} \mathrm{O}_{3}$, etc.), and trace element analysis ( $\mathrm{As}, \mathrm{Hg}, \mathrm{Cd}, \mathrm{Cr}, \mathrm{Pb}$, and $\mathrm{Se}$ ). Advanced fuel analysis using chemical fractionation (CHF) and computer-controlled scanning electron microscopy (CCSEM) was done under this project. CCSEM is used to determine the size, composition, and association of the mineral species in fuel that are greater than $1 \mu \mathrm{m}$ in diameter. CHF quantifies organically bound inorganics and minerals that are less than $1 \mu \mathrm{m}$ in size. Organically bound inorganics are found only in low-rank fuels, and they comprise the bulk of the inorganics that are less than $1 \mu \mathrm{m}$ in size. Together, CCSEM and CHF give a complete inorganic characterization of any type of fuel; this information is crucial for identifying the fuel-related root causes of ash deposit formation in a boiler and is also used in predictive modeling.

\section{Modeling}

The data produced by the advanced and conventional fuel analyses were used as input for running predictive models or indices. Two models were used in this project to assess ash deposition. The model termed Predictive Coal Quality Effects Screening Tool, PCQUEST, is a computer program designed to output a series of indices that rank fuels according to predicted performance with respect to slag deposit formation, high- and low-temperature-region fouling, fly ash collectibility, slag tapping, and ash erosion. This model requires CCSEM and CHF data as input; therefore, should these data not be available, this model will not be run. A model called the FACT (Facility for the Analysis of Chemical Thermodynamics) code is another computer-based model that is used for assessing fuel quality effects on ash behavior in a boiler. FACT is a thermodynamic equilibrium model that predicts molar fractions (partial pressures) of all gas, liquid, and solid stable 
components in a system by Gibbs free energy minimization. Output from FACT includes quantities, compositions, and viscosities of liquid and solid mineral phases; therefore, the code works well for predicting the behavior of fuel ash, including biomass-derived ash for different boiler temperature regimes. This model is especially useful for extrapolating to different temperature regions in a boiler to assess potential slag or fouling deposit formation, and it is also useful for performing blend evaluations.

\section{Combustion Testing}

Combustion testing for this project involved firing lignite and two lignite-biomass blends in a drop-tube furnace (DTF) system and in a small grate-stoker combustion system. Combustion tests in the DTF are relatively low-cost bench-scale combustion simulations of gas temperature, gas composition, particle residence time, and entrained ash aerodynamics. Tests in the DTF assessed fouling and fine particulate generation, and testing in the small grate-stoker combustion system assessed clinkering or slagging.

Combustion testing in the small grate-stoker combustion system focused primarily on evaluating low-viscosity slag development that could induce clinker formation. The lignite and two lignite-biomass blends were fired in the bench-scale stoker furnace using an excess air level, gas temperature, and gas composition similar to that which is used in the NDSP system. The lignite and blend samples were compared, and an assessment of clinker potential was derived.

\section{Task 4 - Environmental Issues}

The focus of this task is to address technical and operational issues that may potentially impact emissions released from the plant to the environment. These include air, water, and solid emissions/releases. Most of the data were collected during Task 3. Gas analyzers were used to measure $\mathrm{CO}, \mathrm{CO}_{2}, \mathrm{O}_{2}, \mathrm{NO}_{\mathrm{x}}$, and $\mathrm{SO}_{\mathrm{x}}$ concentrations from bench-scale combustion equipment. The particle-size distribution of the fly ash and the corresponding carbon carryover or loss-on-ignition quantity were determined in the DTF. The size and composition distribution of the fly ash was also determined by CCSEM analysis. This information was used to assess potential particulate emissions for the lignite-biomass blends. Emissions of mercury and other significant trace elements measured in the fuels were estimated using the in-house predictive models for these emissions based on fuel analyses.

\section{Task 5 - Energy Production Assessment}

The focus of this task was to determine and quantify the impact that biomass firing will have on energy (steam/heat) production and define options and/or firing strategies that will result in optimal use of biomass for energy production. The potential exists to convert the penitentiary's steam heat facility to a cogeneration plant and provide steam for other uses such as absorbtion chillers. These opportunities affect the decisions that go into equipment selection, process flow arrangement, and various cycle analysis. The completion of this task was necessary to identify the most beneficial application of technology for the various opportunities that cofiring of biomass offers for the penitentiary facility. 


\section{Task 6 - Engineering Economic Analysis}

An economic analysis was carried out using guidelines set forth by the state of North Dakota in evaluating new projects. Specific considerations for utility rate schedules and requirements for budgeting at state facilities were factored into the economic analysis. These considerations make the document useful for the end user.

\section{TASK 1 - LOCAL BIOMASS RESOURCE ASSESSMENT}

The first and most important step in the process of any biomass-related feasibility study is identifying a secure biomass fuel resource. With respect to the NDSP needs, identifying an available low-cost source of biomass was paramount to creating an attractive economic scenario. The scope of this task consisted of looking at theoretically available biomass supplies in order to narrow-down the search for specific viable resources. This helped to minimize time and effort and allowed for a detailed focus on the most promising resources. The results of this task were presented to the NDSP, DCS, and potential fuel suppliers. Meaningful discussion during the presentation helped to direct our efforts and corroborate data.

The EERC has developed methods for estimating national biomass resources as described in Schmidt and Pinapati (1). These methods were used to estimate biomass residues located within 100mile radius of Bismarck, North Dakota. A 100-mile radius, shown in Figure 2, was chosen because costs to transport biomass greater than 100 miles can require delivered biomass fuel costs exceeding delivered coal costs. Lignite coal of similar heating value to wood is delivered to NDSP at

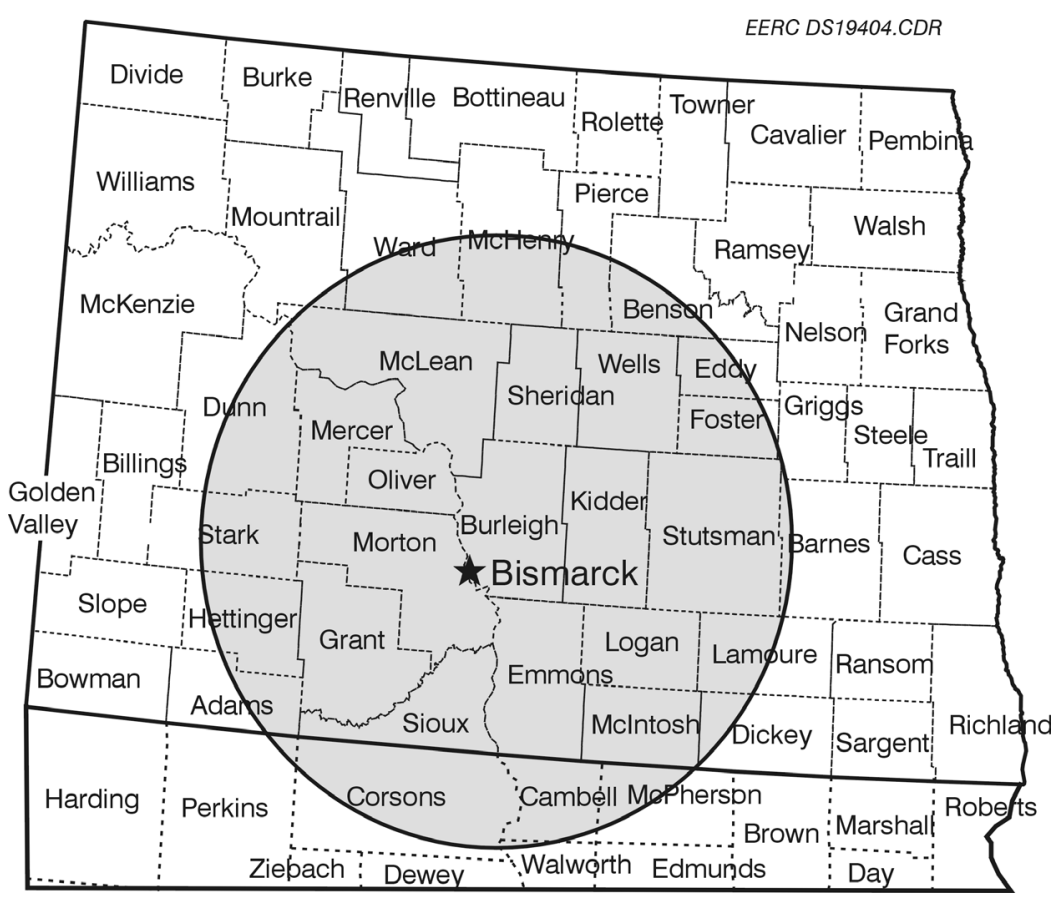

Figure 2. Counties within 100-mile radius of Bismarck, North Dakota. 
approximately $\$ 20 /$ ton. Hauling estimates provided by several vendors suggested rates of about $\$ 15 /$ ton for a 75 -mile distance. Unless unique circumstances are present, the 100-mile radius provides a good rule of thumb. The results of the theoretical estimates are presented in Table 1. Details of how these estimates are calculated are found in Schmidt and Pinapati (1).

Table 1. Theoretically Available Biomass Within 100-mile Radius of Bismarck

\begin{tabular}{ccc}
\hline Theoretically Available Biomass (all sources combined) & 2.6 million tons/yr \\
\hline $\begin{array}{c}\text { Woody Residues } \\
2.3 \% \text { of total }\end{array}$ & $\begin{array}{c}\text { Agricultural Residues } \\
91.3 \% \text { of total }\end{array}$ & $\begin{array}{c}\text { Human Residues } \\
6.4 \% \text { of total }\end{array}$ \\
\hline & Normalized Subtracting Crop Residues \\
\hline $13.2 \%$ of total & $50.2 \%$ of total & $36.6 \%$ of total \\
\hline
\end{tabular}

The biomass types shown in Table 1 are defined as follows. Woody residues are made up of sawdust from primary and secondary processors or mills and manufacturers, respectively; forest residues from logging activity; and municipal wood supplied from residential, industrial, construction, and demolition sources. Agricultural residues consist of crop residue left on the field in excess of what is required for soil stabilization, processing residues, and animal manure. Human residues are made up of segregated MSW and sewage sludge. All of these materials are potential biomass fuels for the NDSP facility.

We began our resource investigation by analyzing the above data and eliminating the least promising possibilities. On the surface, the results of the theoretical data tended to indicate that agricultural sources might be available in large quantity and should be the first point of focus. It was found that crop residues comprised the majority of total available biomass: $82 \%$ ! However, crop residues are widely dispersed, and the logistics of gathering the resource are difficult since each individual farmer must supply the resource. Costs cannot compete with coal. This is the problem that energy crop researchers face, and as data indicate from studies with switchgrass (typical hay crop) (2), $\$ 40.00$ to $\$ 60.00$ per ton is the expected delivery costs. Even the most promising studies investigating the use of corn stover estimate $\$ 23 /$ dry ton delivered (3), which is more than the cost of lignite coal delivered to NDSP. Although these data were discouraging relative to NDSP, based on the shear quantity of crop residues in North Dakota, the state should consider future research efforts, which could decrease logistical barriers, and costs for using crop residues as fuel.

The data were normalized eliminating crop residue in the count. The results indicated that agricultural residues comprised $50 \%$ of the total, with human residues at $37 \%$ and woody residues at $13 \%$. In light of these data, we examined the subcategories and eliminated the small contributors for potential further investigation. Sewage sludge, mill residue, and forest residue were the lowest quantities, accounting for less than $4 \%$ of the normalized total; hence they were eliminated. Animal manure, although accounting for over $13 \%$ of the normalized total, was eliminated because of logistics, odor, and handling issues. This left the categories shown in Table 2 for detailed investigation of various attributes, including quantity, cost, availability, reliability, and quality. 
Table 2. Theoretical Quantities of the Most Promising Biomass Resources Within 100-mile Radius of Bismarck, ND

\begin{tabular}{lc}
\hline Biomass Fuel Type & Theoretical Quantity \\
\hline 1. Municipal Woody Residues & 56,846 tons/yr \\
2. Agricultural Processing Residues & 171,853 tons $/ y r$ \\
3. Municipal Solid Waste & 156,139 tons/yr \\
\hline
\end{tabular}

The theoretical numbers provided in Table 2 exceed consumption requirements of the NDSP and were deemed appropriate estimates in which to embark on obtaining further information on the above resources. NDSP consumes approximately 2500 tons/yr of lignite coal for heating purposes, operating only 7 months out of the year. If the current boiler were operated at full capacity $100 \%$ of the year, it could potentially consume approximately 20,000 tons/yr of lignite coal. MSW was eliminated from the list for further investigation. Permitting and fuel-handling characteristics cause MSW to be extensively more difficult to implement than wood or ag-processing residues. Therefore, data on wood and ag-processing residues were the only detailed information collected.

\section{Agricultural Processing Residues}

North Dakota maintains its reputation as the leading cereal crop producer in the nation. According to the U.S. Department of Agriculture (4), North Dakota is ranked the No. 1 producer of spring wheat, durum wheat, sunflowers, barley, dry edible beans, pinto beans, canola, and flaxseed. North Dakota is ranked No. 2 for production of all wheat, oats, navy beans, dry edible peas, and honey. North Dakota is ranked No. 3 for sugar beets and lentils. All of the above crops require processing. The opportunity was to identify local processors and determine the waste residues that may be used as fuel.

In the Bismarck area, agricultural processors were interviewed to obtain data on processing residues. Processors of sunflowers and sugar beets are primarily located in the Red River Valley of North Dakota outside the 100-mile radius of Bismarck. All the other crops listed are generally handled by local grain elevators and then shipped to out-of-state distributors or processors. Twentyfive grain elevators or processors were contacted concerning potential residues. A detailed list is provided in Appendix A. About 5000 tons/yr of material was verified as available. However the average cost was about $\$ 20$ per ton, not including delivery. Primarily grain elevator screenings, these residues are sold to farmers for cattle feed. Archer Daniels Midland Corporation is the only significant processor in the region. The plant produces no usable waste of any significant quantity. Therefore, the investigation of agricultural processing residues did not yield a significant economically usable fuel resource for the NDSP.

\section{Municipal Woody Residues}

This category proved to be the most successful for securing an economically viable fuel resource for the NDSP. The data suggest that there is approximately 30,000 tons/yr of wood available within 100 miles of Bismarck. This number is based on actual conversations with landfills, tree services, municipal waste haulers, and commercial industry. The amount of material that was 
confirmed by specific sources within the immediate Bismarck area such as tree services and industry was 8000 tons/yr. A detailed breakdown is provided in Appendix A. This amount was estimated by the specific haulers through telephone interviews and is considered a conservative approximation of the amount of material we could expect to be delivered to the NDSP. Other data supporting these estimates were gathered from local landfills and is summarized in Table 3.

Table 3. Landfill Summary

\begin{tabular}{lc}
\hline Landfill/Distance from NDSP & Notes on Resource \\
\hline Bismarck Landfill/Bismarck & 7900 tons/yr \\
Mandan Landfill/5-10 miles from NDSP & 5000 tons/yr \\
County Landfill/91 miles - Glenham, SD & 600 tons/yr can segregate and grind \\
Mercer County/50 miles - Stanton, ND & Quantity not recorded, \$21/ton tipping fee \\
McDaniel Landfill/100 miles - Sawyer, ND & Quantity not recorded \\
Jahner Sanitation/60 miles - Linton, ND & Not contacted \\
City of Dickinson Landfill/100 miles & Estimated 3000 tons/yr \\
City of Jamestown Landfill/100 miles & Estimated 3000 tons/yr \\
City of Minot Landfill/100 miles & Estimated 3000 tons/yr \\
\hline
\end{tabular}

The landfill data tend to support the quantities suggested by the local tree services and industries. The groups hauling woody debris to the local landfills (Bismarck and Mandan) are comprised of tree services, municipal waste haulers, and miscellaneous private industries. All of these haulers pay a $\$ 10$ per ton tipping fee to the landfill for woody debris. Haulers typically drive past the NDSP to get to the Bismarck landfill, which is within 5 miles of NDSP. Mandan area haulers take material directly to the Mandan landfill on the opposite side of the city. Interviews suggest that haulers would be interested in dropping off material at NDSP if there were no tipping fee. Haulers in the Mandan area would be interested in driving the extra 10 miles across town to deliver material to NDSP only if there were no fee. A $\$ 5 /$ ton tipping fee was discussed, but considered an unattractive option to all haulers.

The data concerning municipal wood supply in the Bismarck/Mandan area are summarized here with detailed information available in Appendix A. Detailed investigation was required to ensure an adequate fuel supply to the NDSP. Telephone interviews provided information from each individual supplier on aspects of wood residue costs, quantity, quality, availability, and reliability. Potential suppliers attended a meeting held at the NDSP February 1, 2001, and provided additional input. In general, we discovered the following.

\section{Cost}

All suppliers are willing to deliver wood residue material to the NDSP for free. The delivered fuel cost assumption is $\$ 0 /$ ton. Most suppliers are not willing to pay any tipping fee. Most likely, if a tipping fee of $\$ 5 /$ ton were imposed, we would lose half the potential fuel supply. Haulers in the Mandan area would not deliver to NDSP if a tipping fee were imposed. 


\section{Quantity}

8000 tons/yr of material was verified though interviews. The reliability of this information should be fairly accurate. Although suppliers did not have recorded data by weight, they could easily estimate the amount of material hauled on a weekly basis by volume, or they knew what their landfill tipping fees totaled. From these numbers, a weight was calculated. Assumptions included $15 \mathrm{lb} / \mathrm{ft}^{3}$ bulk density of wood and a \$10/ton tipping fee to arrive at the approximate weights. The wood residue haulers agreed at the Feburary meeting that once the NDSP project was implemented, significantly greater amounts of wood waste would probably become available and that the estimate of 8000 tons/yr could be considered a good conservative estimate. Landfill records seem to support the quantification given that the Bismarck Landfill registered 7900 tons per year and the Mandan landfill estimated receiving a similar amount.

\section{Quality}

Given a quantity of 8000 tons/yr, $52 \%$ is expected to come from tree services. This material would include all parts of the tree leaves, branches, bark, trunks, and stumps. A large majority is from the city trees comprising cottonwood, elm, box elder, and oak. The second largest supply would come from primarily from one local municipal waste hauler. This amount accounts for $32 \%$ of the total and is made up of construction and demolition (C\&D) debris and commercial wood waste. The hauler indicated segregation would be required. By eliminating the tipping fee at the landfill, the municipal hauler could offer greater services to their customer, and segregation may be on behalf of the customer, the hauler, or at the NDSP receiving site. An approach for sorting and segregation of received materials is provided in the Task 2 section of this report. The municipal hauler did not view segregation as a significant issue, as long as the NDSP site was set up to keep truck traffic moving efficiently. The remaining wood residue resource would be supplied by private industries that haul their own waste to the landfill. The quality of this resource is quite high, consisting of clean sawdust, $2 \times 4$ edgings, and pallets. In all cases, material must be screened and ground in order to process in the boiler at the NDSP.

In general, the collected wood waste can be expected to have an average delivered moisture content of $25 \%$ to $35 \%$. Even the wettest wood should not exceed $50 \%$ moisture. Delivered heating value will be approximately $7500 \mathrm{Btu} / \mathrm{lb}$; once dry, the wood has a heating value of over $8000 \mathrm{Btu} / \mathrm{lb}$. Comparatively, lignite coal is $6700 \mathrm{Btu} / \mathrm{lb} @ 36.8 \%$ moisture. Also, wood will have 4 times less sulfur and over 3 times less ash than lignite coal. Other fireside performance issues are explained in the Task 3 section of this report. In general, we expect improved environmental performance, similar fuel consumption rates, and improved fireside performance.

\section{Availability}

Availability can be described as the ability to obtain the resource. In all cases of resource supplied from tree services, municipal haulers, or private companies, the parties agreed that dropping material at the NDSP site would be attractive. Municipal haulers seemed to have the highest level of need since many of their customers currently do not segregate material. In cases where fuel cannot be segregated in advance, the NDSP will have the capability of segregating fuel on-site prior to processing. Unwanted debris can then be transferred to the Bismarck landfill. It will be paramount 
for the NDSP to determine whether a truck should unload on-site or be passed on to the Bismarck landfill in the event that too much noncombustible material is present. Outdoor and indoor storage of biomass fuel will be available. An easy-access drive-through approach is designed that is amenable to self-dumping trucks.

\section{Reliability}

Reliability of the resource is defined as the cyclical nature of supply whether on an annual basis or projected future yearly basis. In general, the expected reliability of the municipal woody biomass is excellent. The majority of the resource is from tree service companies. It can be expected that fuel availability will increase during the summer and decrease in the winter. However, all the local tree services work year-round and claim that their residue deliveries would be fairly consistent. Also, the amount available in future years is expected to be consistent. The municipal haulers get material from a variety of sources, and volume follows a similar summer/winter cycle as do tree services. Future supply can be linked to population statistics. Bismarck is a city of 52,000, and the surrounding counties grew $10 \%-15 \%$ in the last year. The private suppliers of wood waste include two truss manufacturers and a pallet recycler. The supply is based on the viability of the business, which is expected to be good. Their supply is, again, higher in the summer but fairly consistent throughout the year. In no case is the volume of woody residues expected to decrease or be diverted to other higher value uses. The tree services do chip material and sell as bedding; however, the value does not provide a significant profit or comprise a significant percentage of their business.

\section{TASK 2 - FUEL-HANDLING ISSUES}

Task 2 was initiated upon the completion of Task 1. Once the most promising fuel resource was identified, the design of the fuel-handling system could be completed. The kickoff of this task included input provided by the potential fuel suppliers, since a handling and receiving site would be required. A complete design package is included in Appendix B. The package includes site plan drawings, equipment specifications, and costs. Highlights have been pulled from the drawings in Appendix B and are presented in the figures that follow.

The site plan in Figure 3 shows the layout of a fuel preparation site adjacent to the NDSP boiler house. Trucks are intended to enter the site via the lift station road and leave using industries road. Trucks may approach the site using either road, but traffic through the site is one way. Two outdoor storage piles with the capacity to store 375 tons of material (1 week at maximum capacity) each are planned. One pile is designated for separated commercial debris and the other of tree limbs, branches, etc. These piles constitute unconditioned large-diameter material. Clean presized or preconditioned debris will be received directly into the $80^{\prime} \times 100^{\prime}$ fuel storage building. Approximately 120 tons can be stored in this preconditioned receiving station. Unconditioned fuel is processed in a CBI Grizzly Mill. Specifications are in Appendix B. A front-end loader transfers material from the unconditioned piles to the Grizzly Mill. The material will be screened using a 1" taper slot screen manufactured by Action Equipment Company and integral to the CBI equipment. Undersized material will be discarded in a rolloff dumpster and hauled to the landfill. After screening and metal separation, the fuel is ground to nominal 2" diameter with the hammer mill. The 


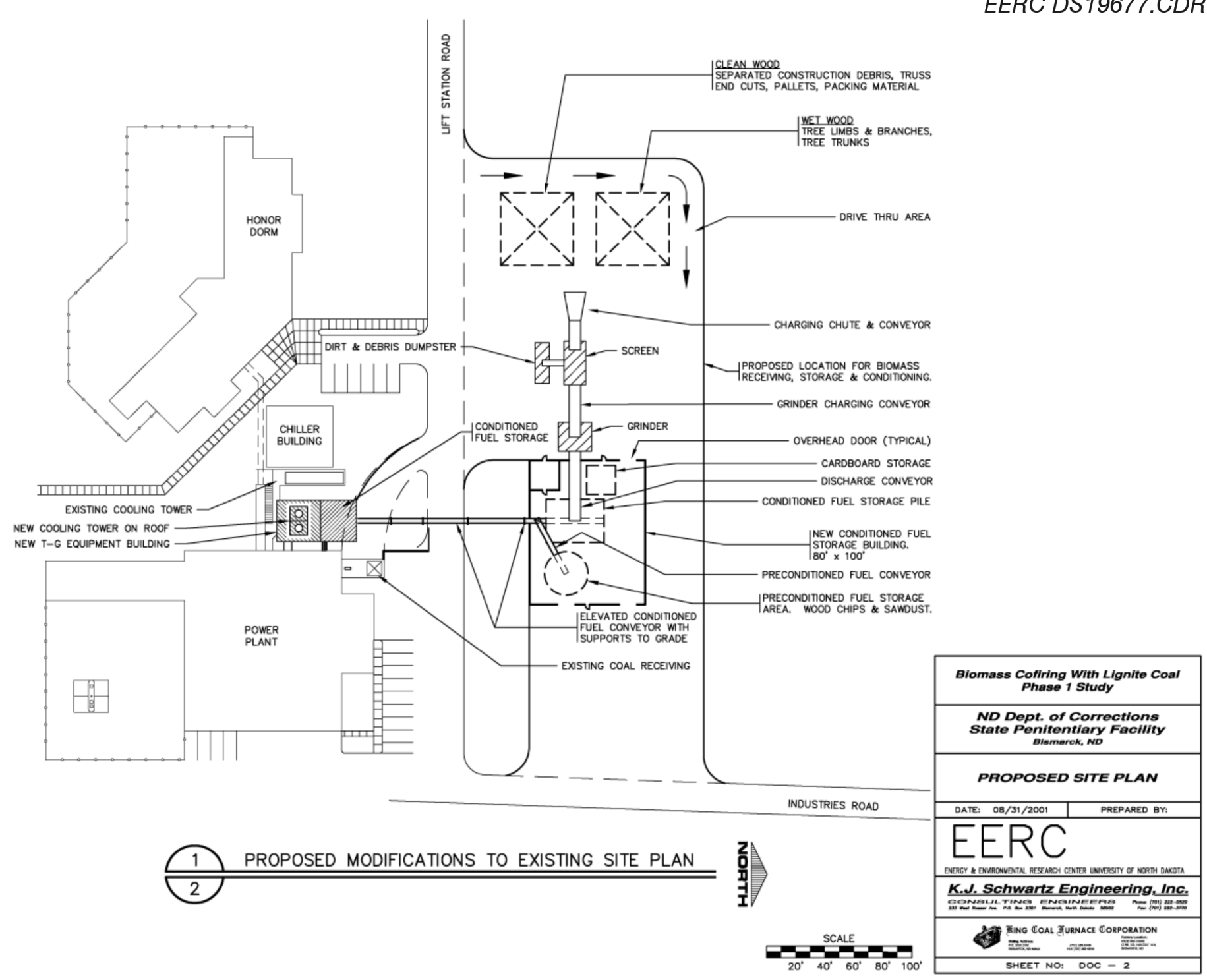

Figure 3. Proposed site plan. 
fuel is conveyed into a building for storage. Approximately 170 tons can be stored at the discharge of the Grizzly Mill. Both conditioned indoor fuel storage piles will automatically be conveyed overhead across the lift station road to a bunker drying bin for the boiler. The bunker drying bin is aerated and can use waste heat from the exhaust stack if necessary. The bunker drying bin has a capacity of $9391 \mathrm{ft}^{3}$ or 3 days of fuel storage. The bunker drying bin is fully automated and feeds material to a surge hopper which then feeds the stoker. Finally, a dual-fuel stoker will supply material to the boiler. These stokers are a commercially proven technology provided by Detroit Stoker Company. For an equipment budget and visual representation of the process, see the process flow diagram and specifications presented in Appendix B.

In order for the old stoker to handle wood chips, modifications are planned for the boiler. A hydrograte will be installed. A hydrograte produced by Detroit Stoker Company is a vibratory, sloped, water-cooled grate. This new grate will replace the existing chain grate which currently is less tolerant of higher volatility fuels. Dry wood chips react faster inside the boiler and contain less ash. These two attributes create higher potential for exposure of the grate surface to excessive temperatures. Water-cooled hydrogrates eliminate this potential operational problem. In order to install the hydrograte, the boiler will need to be raised 3 feet.

The previous description of the process design was based on the handling issues and requirements relative to the most promising source of biomass supply for the NDSP. The theoretical requirements for design are summarized in Table 4.

\section{TASK 3 - FIRESIDE ISSUES}

Fireside issues are defined as the implications of fuel combustion on boiler maintenance. Fireside issues relative to the NDSP and utility-scale systems were addressed in this task through characterization of fuel components, modeling, and bench-scale testing. The results are summarized and presented as follows.

\section{Fuel Characterization and Modeling}

\section{Introduction and Description of Samples and Analysis Data}

A sample of the lignite coal fired at the NDSP was obtained for analysis, along with samples of mixed wood chips and chipped tree wood. These are referred to in the report as the lignite, wood chips, and tree wood, respectively. Proximate analyses were performed using American Society for Testing and Materials (ASTM) procedure D5142-90, ultimate analyses using ASTM D5373-93 and D5016-89, and the bulk ash chemistry of the fuels determined using ASTM procedure D4326-94. The EERC as-received proximate and ultimate results for the samples are given in Table 5. The EERC bulk ash chemistry results are given in Table 6.

The PCQUEST calculations to predict slagging and fouling behavior also required CCSEM analysis, image analysis (IMA), and CHF analysis. CCSEM analysis is used to determine the size 
Table 4. Design Philosophy

\begin{tabular}{|c|c|}
\hline Requirement & Result \\
\hline $\begin{array}{l}\text { Most promising biomass choice based on } \\
\text { cost, quantity, quality, availability, and } \\
\text { reliability. }\end{array}$ & $\begin{array}{l}\text { Municipal woody residue consisting of cut } \\
\text { trees, chips, sawdust, edgings, pallets, C\&D } \\
\text { debris }\end{array}$ \\
\hline Design Requirements & Results \\
\hline 1. 1 week of fuel-receiving capacity & $\begin{array}{l}\text { Large outdoor pile storage and some indoor } \\
\text { surge storage. }\end{array}$ \\
\hline $\begin{array}{l}\text { 2. Efficient load transfer and heavy truck } \\
\text { traffic flow }\end{array}$ & $\begin{array}{l}\text { Site plan was arranged for easy dump access } \\
\text { and one-way through-site traffic with access } \\
\text { from any outside direction. }\end{array}$ \\
\hline $\begin{array}{l}\text { 3. Minimal on-site sorting, some required, } \\
\text { manual labor can be utilized at low } \\
\text { costs }\end{array}$ & $\begin{array}{l}\text { Outdoor storage piles can be sorted manually; } \\
\text { however, efforts to presegregate materials on } \\
\text { behalf of the municipal haulers will have to be } \\
\text { implemented to minimize unwanted materials. }\end{array}$ \\
\hline 4. Screening & $\begin{array}{l}\text { CBI } 1 / 4 \text { " screen for removing fines prior to the } \\
\text { hammer mill. Oversized material that cannot } \\
\text { feed to the hammer mill will be reduced with } \\
\text { chain saws. No oversized screen is required } \\
\text { after the hammer mill. }\end{array}$ \\
\hline 5. Metal separation & $\begin{array}{l}\text { Three locations are provided for pulley } \\
\text { magnets. 1) prior to the hammer mill, 2) at the } \\
\text { discharge of the hammer mill conveyor, and } \\
\text { 3) at the discharge into the dryer. }\end{array}$ \\
\hline 6. Low intensity drying & $\begin{array}{l}\text { Indoor storage of 1-day capacity is provided } \\
\text { for air drying, and a continuous dryer with the } \\
\text { potential for using hot flue gas is provided. }\end{array}$ \\
\hline 7. Fuel conveying to boiler & $\begin{array}{l}\text { Rapat cleated belt conveyors and augers are } \\
\text { specified. }\end{array}$ \\
\hline $\begin{array}{l}\text { 8. Fuel stoking for wood chips/blending } \\
\text { control with coal }\end{array}$ & $\begin{array}{l}\text { A Detroit dual-fuel stoker is specified. PLC } \\
\text { logic will provide settings for automatically } \\
\text { controlled blend ratios. }\end{array}$ \\
\hline 9. Ash handling for biomass & A Detroit hydrograte is specified. \\
\hline
\end{tabular}

and composition of the mineral species in a fuel that are greater than $1 \mu \mathrm{m}$ in diameter, along with IMA to determine the association of the mineral species. CHF analysis quantifies inorganic materials, which are ion-exchangable, and minerals that are less than $1 \mu \mathrm{m}$ in size. Organically bound inorganics are found only in low-rank fuels such as lignite and comprise the bulk of the inorganics that are less than $1 \mu \mathrm{m}$ in size. Together, CCSEM and CHF give a complete inorganic characterization of a fuel. A complete description of the PCQUEST model is given in Appendix C.

A summary of the CCSEM size distribution of mineral phases is given in Table 7 and a summary of the CHF results in Table 8. The complete CCSEM and CHF analysis results are given in Appendix C. 
Table 5. Proximate and Ultimate Analysis

\begin{tabular}{lccc}
\hline & Lignite & $\begin{array}{c}\text { Tree } \\
\text { Wood }\end{array}$ & $\begin{array}{c}\text { Wood } \\
\text { Chips }\end{array}$ \\
\hline Proximate Analysis, as received (wt\%) & & & \\
$\quad$ Moisture & 36.8 & 6.8 & 7.3 \\
Volatile Matter & 30.06 & 75.87 & 76.82 \\
Fixed Carbon & 27.25 & 15.40 & 15.25 \\
Ash & 5.89 & 1.93 & 0.63 \\
& & & \\
Ultimate Analysis, as received (wt\%) & & & \\
Hydrogen & 6.75 & 6.37 & 6.12 \\
Carbon & 40.95 & 45.13 & 46.85 \\
Nitrogen & 0.96 & 0.83 & 0.17 \\
Sulfur & 0.74 & 0.19 & 0.18 \\
Oxygen & 44.72 & 45.55 & 46.05 \\
Ash & 5.89 & 1.93 & 0.63 \\
& & & \\
Heating Value, Btu/lb & 6700 & 7801 & 8274 \\
\hline
\end{tabular}

Table 6. Bulk Ash Chemistry

\begin{tabular}{lrrc}
\hline Oxide, $\mathrm{wt}^{\%}$ & Lignite & Tree Wood & Wood Chips \\
\hline $\mathrm{SiO}_{2}$ & 19.8 & 7.1 & 27.7 \\
$\mathrm{Al}_{2} \mathrm{O}_{3}$ & 11.3 & 1.3 & 11.0 \\
$\mathrm{Fe}_{2} \mathrm{O}_{3}$ & 10.7 & 2.0 & 10.0 \\
$\mathrm{TiO}_{2}$ & 0.4 & 0.1 & 0.5 \\
$\mathrm{P}_{2} \mathrm{O}_{5}$ & 0.1 & 8.2 & 1.4 \\
$\mathrm{CaO}$ & 20.3 & 44.5 & 28.4 \\
$\mathrm{MgO}$ & 5.6 & 8.3 & 5.9 \\
$\mathrm{Na}$ & 7.9 & 0.1 & 4.9 \\
$\mathrm{~K}_{2} \mathrm{O}$ & 0.8 & 25.8 & 7.6 \\
$\mathrm{SO}_{3}$ & 23.2 & 2.6 & 2.5 \\
\hline
\end{tabular}

\section{Fireside Modeling Predictions}

The PCQUEST program developed at the EERC determines combustion performance indices, including the potential for furnace wall slagging and convective pass fouling of various fuels. Slag is defined as the more fluid-type of ash material that forms only in the hottest temperature radiant section of a boiler. Fouling deposits are formed only in the cooler temperature regions of a boiler in the region of the secondary and primary superheaters and reheaters. Slagging deposits would form on radiant zone waterwalls in a pulverized coal-fired system or on the burning bed of fuel in a stokerfired boiler, while fouling deposits would form on heat-transfer tubes in the convective pass of a boiler. The indices are on a scale of $0-100$, with $0-33$ being low, 34-66 being medium, and $67-100$ 
Table 7. CCSEM Mineral Distribution, wt\%

\begin{tabular}{lrrr}
\hline Mineral Fraction: & $\begin{array}{c}\text { Lignite } \\
5.889\end{array}$ & $\begin{array}{c}\text { Tree Wood } \\
2.534\end{array}$ & $\begin{array}{c}\text { Wood Chips } \\
1.467\end{array}$ \\
\hline Mineral & & & \\
Quartz & 10.9 & 7.3 & 6.7 \\
Iron Oxide & 1.4 & 4.2 & 27.4 \\
Calcite & 0.3 & 27.5 & 0.6 \\
Dolomite & 0.3 & 5.0 & 0.0 \\
Kaolinite & 7.9 & 0.2 & 2.8 \\
K Al-Silicate & 6.6 & 3.2 & 6.5 \\
Fe Al-Silicate & 3.5 & 1.0 & 2.0 \\
Mixed Aluminosilicate & 7.7 & 0.8 & 6.4 \\
Fe Silicate & 0.0 & 0.0 & 4.0 \\
Ca Silicate & 0.1 & 1.6 & 0.2 \\
Pyrite & 2.2 & 0.0 & 0.0 \\
Pyrrhotite & 35.4 & 0.0 & 0.8 \\
Oxidized Pyrrhotite & 1.0 & 1.0 & 8.1 \\
Gypsum/Aluminosilicate & 0.4 & 2.5 & 1.8 \\
Silica-Rich & 3.1 & 2.7 & 2.4 \\
Unknown & 14.4 & 37.9 & 23.5 \\
\hline
\end{tabular}

Table 8. Chemical Fractionation Analysis

\begin{tabular}{lccc}
\hline \multicolumn{4}{c}{ Amount Soluble in Water and Ammonium Acetate, $\mathrm{wt} \%$} \\
\hline $\mathrm{Si}$ & Lignite & Tree Wood & Wood Chips \\
$\mathrm{Al}$ & 0 & 53 & 76 \\
$\mathrm{Fe}$ & 0 & 55 & 75 \\
$\mathrm{Ti}$ & 12 & 71 & 66 \\
$\mathrm{P}$ & 6 & 66 & 67 \\
$\mathrm{Ca}$ & 27 & 90 & 79 \\
$\mathrm{Mg}$ & 74 & 70 & 97 \\
$\mathrm{Na}$ & 77 & 92 & 96 \\
$\mathrm{~K}$ & 99 & 57 & 96 \\
$\mathrm{~S}$ & 19 & 100 & 90 \\
\hline
\end{tabular}

being a high or severe value. The resolution of the calculations is such that differences of $2-3$ index units indicate effectively the same performance.

PCQUEST calculations were performed on the pure lignite, tree wood, and wood chip fuels as well as on calculated blends to determine the effect of blend ratio. Indices for these blends were calculated at $10 \%$ increments by weight. The calculations were performed using parameters for the boiler, which was assumed to be at $100 \%$ load. The results of PCQUEST index calculations are 
given in Figures 4 and 5 for the low- and high-temperature fouling, slagging, and opacity indices for the lignite-tree wood and the lignite-wood chip blends, respectively.

The proximate-ultimate analysis results show that the tree wood and wood chip samples are characterized by a significantly lower moisture and ash content than the lignite coal, along with a much higher volatile matter content. The lower moisture results in a $16 \%-20 \%$ higher heating value for the biomass fuels than for the lignite coal. This, along with the lower ash content, makes them attractive as fuels.

The bulk ash chemistry of the two wood fuels differs significantly, with the tree wood having high levels of calcium, potassium, and phosphorus with little silica, alumina, or iron, while the wood chips contains a greater amount of silica than the lignite, with comparable alumina and iron levels. The wood chips also have a moderately higher level of potassium. Both the tree wood and wood chips contain substantially less sulfur than the lignite coal. The high calcium and potassium levels, combined with the sulfur in the lignite, may form calcium and potassium sulfate deposits in lowtemperature regions (below 1800EF) of the boiler when cofired.

The major mineral phases identified by CCSEM in the lignite coal are quartz, clays (kaolinite, potassium aluminosilicate, and aluminosilicate), and pyrite compounds. The tree wood contains considerable calcite $\left(\mathrm{CaCO}_{3}\right)$ along with some quartz and clay materials. The wood chips contain a high level of iron oxide, calcite, and pyrite compounds along with some clay minerals. Both biomass samples have a large amount of "unknown" inorganic material arising from the wood structure which does not fit the normal mineral classifications. It is believed that the high iron content of the wood chips is a result of treatment and processing of the material from the furniture plant from which it was received.

The CHF analysis shows that the majority of all elements in the tree wood and wood chips are soluble or ion-exchangable. For elements of concern which tend to form fine particulate leading to fouling deposits $(\mathrm{Ca}, \mathrm{Na}$, and $\mathrm{K}$ ), the biomass samples have soluble or ion-exchangable values similar to, or somewhat higher than, the lignite coal. However, these higher values are compensated for by the lower ash content of the biomass samples.

The PCQUEST indices (low-temperature fouling, high-temperature fouling, slagging, and opacity) for blends of the tree wood with lignite coal predict no significant change in the lowtemperature fouling index and a slight decrease in the high-temperature fouling index with increasing tree wood blend levels. There is a moderate increase in the slagging index as well as in the opacity index with an increasing percentage of tree wood in the blend. All of the indices remain in the "low" range, except for the opacity index at 100\% tree wood. The PCQUEST results for the wood chips show slight decreases in the high-temperature fouling and opacity indices with increasing wood chip blend levels. There is no significant change in the low-temperature fouling or slagging indices. Overall, the PCQUEST results predict that blends of both biomass fuels with the lignite coal will produce only small changes in slagging, fouling, and opacity relative to the lignite coal itself and that these changes slightly improve fireside performance. 


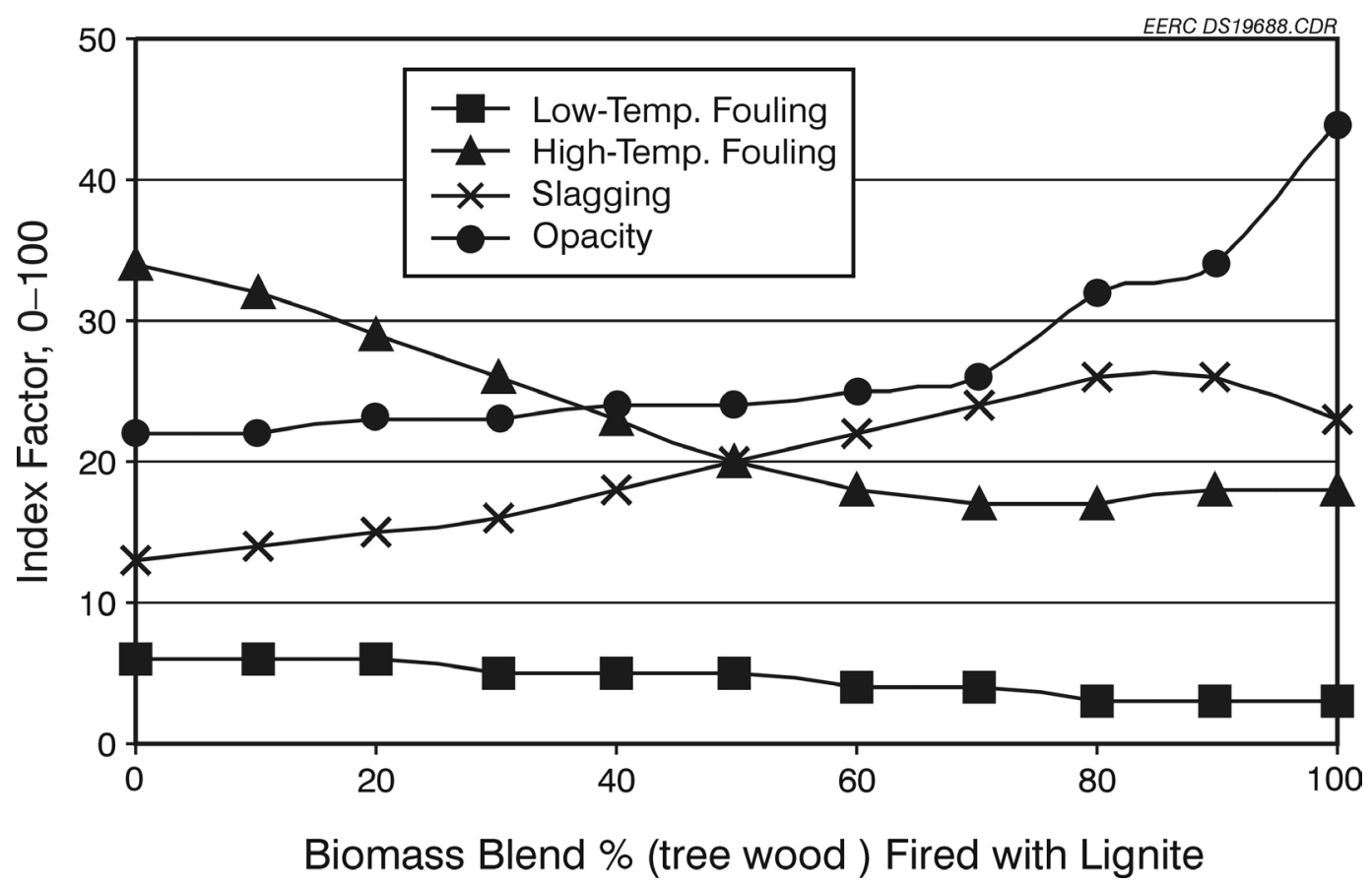

Figure 4. PCQUEST calculation results for various lignite and tree wood blends.

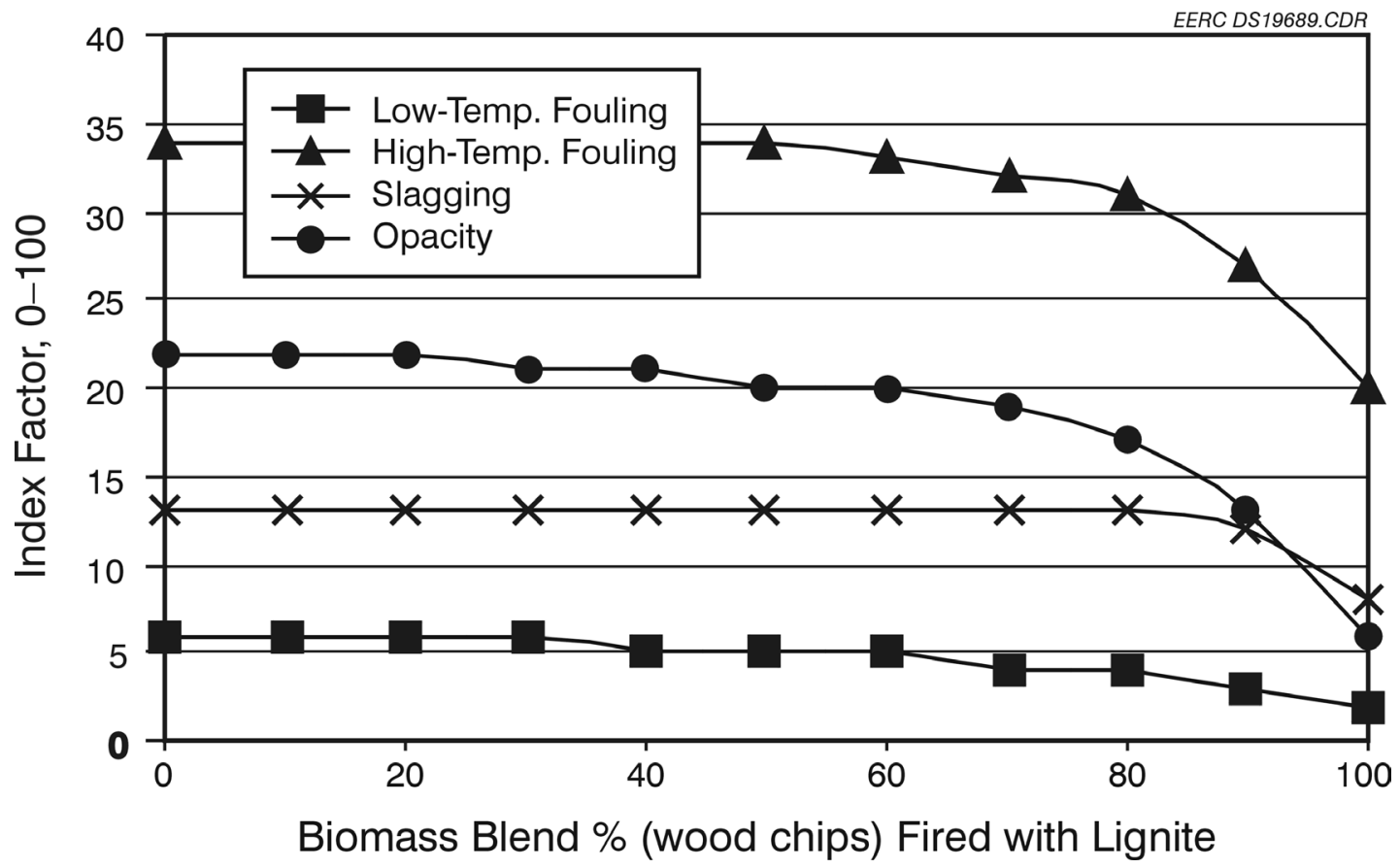

Figure 5. PCQUEST calculation results for various lignite and wood chip blends. 


\section{Equilibrium Thermodynamic and Viscosity Calculations}

The FACT is a set of programs developed to calculate the thermodynamic equilibrium of complex many-component equilibria. Once the initial system composition and pressure is set, FACT determines equilibrium concentrations of solid, liquid, and gas species over a specified temperature range. A more detailed description of the FACT calculations is given in Appendix C.

The sample analyses used in the FACT calculations consisted of the bulk ash chemistry analyses and estimated ultimate analyses. FACT calculations were performed at $25 \mathrm{EC}$ intervals from $500 \mathrm{E}-1500 \mathrm{EC}(932 \mathrm{E}-2732 \mathrm{EF})$ to determine the percentage of liquid phases present as a function of temperature and to provide input for viscosity calculations. Viscosities for the liquid-phase material as a function of temperature were then calculated using a modified form of the Urbain equation in a spreadsheet for each sample. A summary of the results of the FACT calculations are given in Figure 6 . Because of the computational time required by FACT, calculations were performed at $20 \%$ weight percent increments for the lignite-tree wood and lignite-wood chips blends. The complete FACT calculation results are given in Appendix C, which contain numerical listings of viscosity, liquid phases, and the percentage of solid sulfates as a function of temperature.

The FACT calculation results appear promising for the behavior of lignite-wood cofiring. The results predict a consistent decrease in liquid-phase ash viscosity as the level of tree wood in the blends increases. This results in a lowering of the $\mathrm{T}_{250}$ temperature (temperature at which the ash viscosity is 250 poise) by approximately $150 \mathrm{EF}$. However, the lower ash viscosity is compensated for by a concurrent decrease in the amount of liquid-phase ash predicted to be present. The reduced amount of liquid-phase ash results in a "dry" deposit with very little strength. This effect has been seen previously with blends of a bituminous and a subbituminous coal with wheat straw, alfalfa stems, and hybrid poplar wood (5). In these previous experiments, the blend deposits were significantly weaker than deposits formed from either the coal or biomass. FACT calculations for the wood chips indicate very little decrease in viscosity and a small decrease in the percentage of liquid-phase ash with increasing wood chip blend levels. The slagging and fouling behavior of wood chip blends is thus expected to be similar to that of the lignite coal. Neither the tree wood nor wood chip blends are seen to present particular problems when blended with the lignite.

FACT predictions of solid sulfate phases which is indicative of low-temperature sulfate-based fouling shows that the total percentage of solid sulfates formed remains the same with increasing tree wood blend level, although the sulfates do form at a higher temperature. The percentage of solid sulfates forming for blends of the wood chips does show an increase at high blend levels $(80 \%$ and $100 \%$ wood chips). Blends at lower wood chip levels have percentages of solid sulfates equal to or lower than that of the lignite coal.

The conclusions drawn from the PCQUEST modeling and FACT calculation results were that 1) no significantly increased high-temperature fouling or slagging would occur at any blend level of the lignite coal with the tree wood or the wood chips, and increasing the amount of biomass cofired with lignite generally provides slight improvement in fireside performance; 2) the changes in predicted fouling, slagging, and opacity vary directly with the amount of biomass in the blends, with 

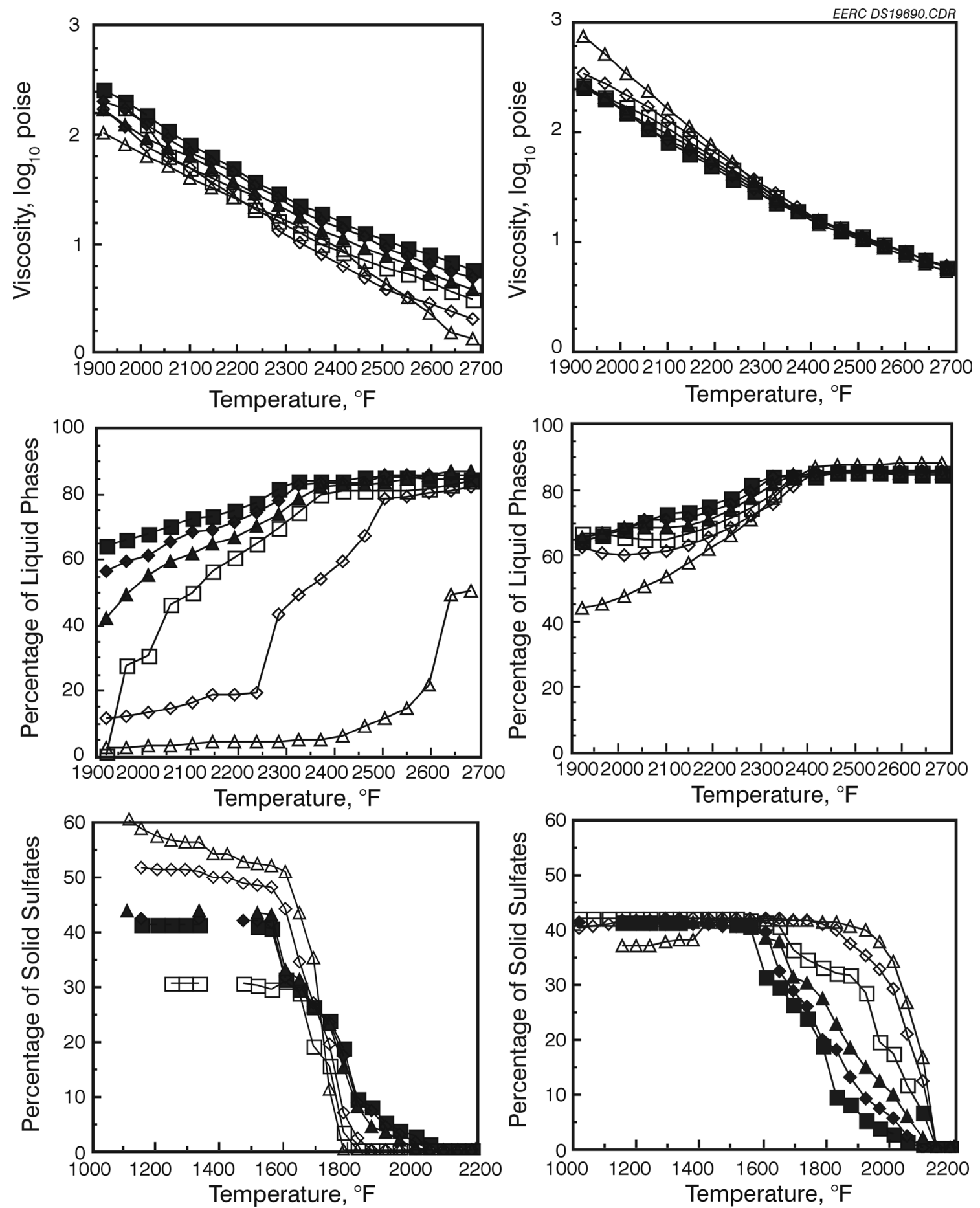

\begin{tabular}{|ll|}
\hline$\square$ Lignite & $\square 60 \%$ Tree Wood \\
20\% Tree Wood & $\diamond 80 \%$ Tree Wood \\
$\Delta$ 40\% Tree Wood & $\Delta 100 \%$ Tree Wood \\
\hline
\end{tabular}

Figure 6. Results from FACT modeling. 
no "optimum" blend level; and 3) opacity and low-temperature fouling behavior may only be moderately adverse at very high biomass blend levels ( $80 \%$ biomass or greater).

The general linear behavior of the PCQUEST and FACT results with biomass blend level resulted in the selection of a 50\% lignite coal-50\% biomass blend for the combustion tests to generate high-temperature fouling deposits. This blend level would allow interpolation to lower blend levels suitable for large power generating plants as well as extrapolation to higher blend levels in stoker boilers. A blend level of $25 \%$ lignite coal- $75 \%$ biomass was selected for the grate clinkering tests. This level would best represent the stoker boiler operation proposed for the NDSP, where high biomass blend levels produce desirable economics.

\section{Utility-Related Fireside Performance}

Samples of Beulah lignite and 50\% blends with tree wood and pallet wood were combusted in the EERC's optical drop tube furnace (ODTF). The samples were analyzed for their propensity to produce convective pass deposits. The chemical nature of these deposits and fly ash was also determined with SEM/energy-dispersive spectrometry techniques and Malvern analysis.

The coal sample was pulverized to $70 \%$ ! 200 mesh. Both wood samples were reduced to a size of $1 / 8$ " and then further reduced in a micro-cutter mill. All fuels were characterized with x-ray fluorescence (XRF), CCSEM, and proximate-ultimate analyses prior to combustion.

A schematic diagram of the ODTF is seen in Figure 7 below. The ODTF has provisions for an optical section, which allows visual and video monitoring of deposit formation and in situ deposit

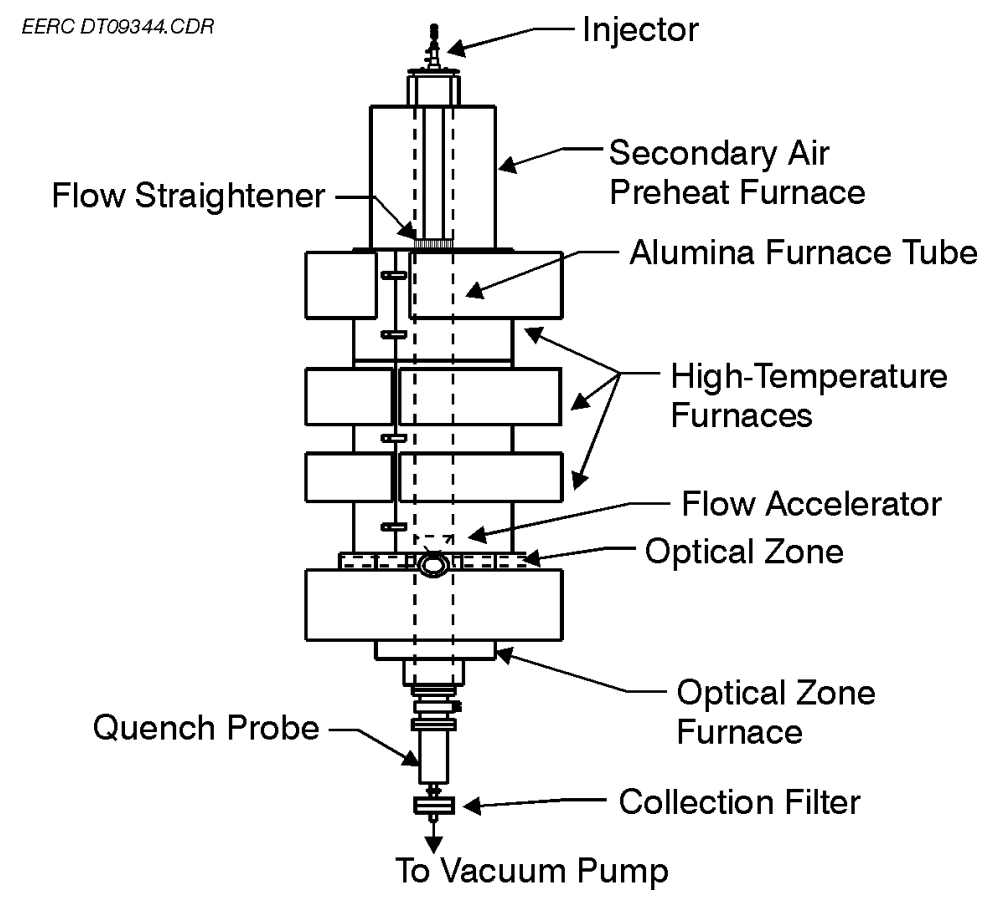

Figure 7. Schematic diagram of the ODTF. 
adhesion strength measurements on the probe. The optical access section also allows in situ temperature measurements by optical pyrometry and entrained particle-size determinations by nearforward-angle laser scattering, as well as the capacity to add additional nonintrusive optical diagnostics shown in the schematic in Figure 7. The ODTF is especially designed to assess the fouling and slagging tendencies of coal. A cylindrical deposition probe with a controlled skin temperature can be inserted into a heated deposition zone, and the initial slagging temperature, deposit adhesion strength, and deposit growth rates can be determined. The heated zones in the furnace reactor tube can be customized to reflect temperature regimes in a real utility boiler. The maximum temperature that can be achieved is 1650EC (3002EF).

The fuel analysis of the Beulah lignite was very typical of a North Dakota lignite coal. The asreceived heating value was approximately $6700 \mathrm{Btu} / \mathrm{lb}$ at $37 \%$ moisture. The CCSEM analysis indicated the presence of primarily pyrrhotite $(35.4 \%)$, an iron sulfide compound, mixed aluminosilicate clays, and quartz. The ash content of the coal was 5.89\% at 37\% moisture. An XRF analysis on the fuel indicated the same elements as the CCSEM analysis. The major elements reported as oxides are $\mathrm{Al}_{2} \mathrm{O}_{3}(11.3 \%), \mathrm{SiO}_{2}(19.8 \%), \mathrm{Fe}_{2} \mathrm{O}_{3}(10.7 \%), \mathrm{CaO}(20.3 \%), \mathrm{SO}_{3}(23.2 \%)$, and $\mathrm{Na}_{2} \mathrm{O}(7.9 \%)$.

The tree wood sample had a heating value of approximately $7800 \mathrm{Btu} / \mathrm{lb}$ at $6.8 \%$ moisture. The CCSEM and XRF analyses indicated a slightly different association of the potential ash material in the tree wood. The major mineral phase was calcite $(27.5 \%)$ with mixed levels of aluminosilicates. The aluminosilicate material is likely due to sample contamination from soil. The XRF data show $\mathrm{CaO}(44.5 \%)$ and $\mathrm{K}_{2} \mathrm{O}(25.8 \%)$ as the predominant elements in the ash. The tree wood had an ash content of $1.9 \%$ at $6.8 \%$ moisture.

Again, the characteristics of the wood chip sample were slightly different than the previously described samples. The heating value was approximately $8200 \mathrm{Btu} / \mathrm{lb}$ at $7.3 \%$ moisture. The CCSEM analysis indicated iron oxide $(27.4 \%)$ as the major mineral phase with the same aluminosilicate clays mixed in minor concentrations. The XRF data show $\mathrm{CaO}(28.4 \%)$ as the major oxide. The ash content is $0.6 \%$ at $7.3 \%$ moisture. All three fuel samples had properties similar to other samples of a similar nature previously examined at the EERC.

\section{Ash Samples}

CCSEM analysis was performed on all ash samples generated in the DTF facility. The CCSEM will give the particle-size distribution and chemical composition of the ash produced.

The Beulah lignite fly ash had a high number of unclassified particles (46.4\%). This simply means the particles did not meet the criteria for one of the specified bins in the CCSEM analysis. The unclassified particles were calcium-rich with traces of $\mathrm{Si}, \mathrm{Al}$, and $\mathrm{Fe}$. The other major phases included quartz (7.6\%), iron oxide (10.1\%), calcium-rich (8.8\%), and mixed aluminosilicates making up the balance of the fly ash. It is interesting to note that the large and small mineral grains present in the fuel combined and fragmented to produce the majority of fly ash particles from 4.6 to $46 \mu \mathrm{m}$ (Table 9). 
Table 9. Results of CCSEM Analysis on Fly Ash from Lignite, Lignite-Pallet Wood, and Lignite-Green Wood Blends, mass \%

\begin{tabular}{lccc}
\hline Phase & Lignite & Lignite-Tree Wood & Lignite-Wood Chips \\
\hline Quartz & 7.6 & 4.2 & 8.6 \\
Iron Oxide & 10.1 & 9.5 & 12.3 \\
Calcite & 1.9 & 6.7 & 1.7 \\
Dolomite & 6.9 & 11.7 & 9.5 \\
Ankerite & 5.0 & 4.2 & 2.9 \\
Na Al-Silicate & 4.7 & - & 1.8 \\
Mixed Al-Silica & - & - & 1.7 \\
Ca Aluminate & 3.8 & 3.6 & 4.2 \\
Si-Rich & 1.8 & 1.4 & 1.9 \\
Ca-Rich & 8.8 & 9.2 & 5.6 \\
Unclassified & 46.4 & 44.9 & 47.9 \\
\hline
\end{tabular}

The fly ash from a 50/50 blend of lignite and tree wood produced ash relatively similar to the pure lignite. Some of the major differences include a higher calcite and calcium-rich content. The most striking difference is in the particle-size distribution of the ash. Figure 8 shows a particle-size distribution of fly ash from all three tests, as determined by CCSEM. Both biomass blends produced larger-sized ash than the pure lignite. The larger ash size will only aid in fly ash collection.

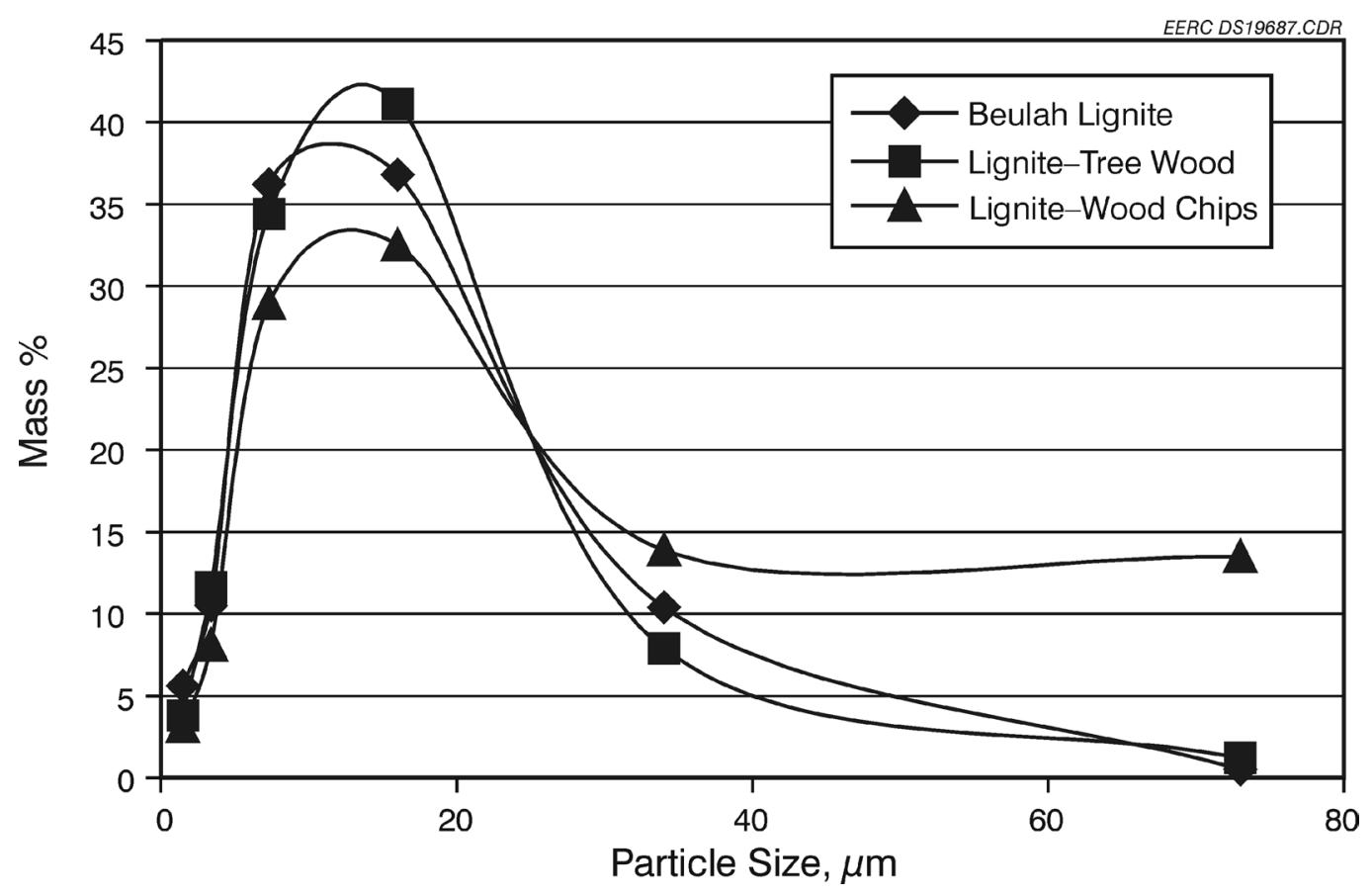

Figure 8. Particle-size distribution for fly ash from lignite, lignite-tree wood, and lignite-wood chips determined by CCSEM. 
Fly ash from the 50/50 blend of lignite and wood chips was also similar to that from the pure lignite. The major differences are in the quartz, iron oxide, calcium-rich, and dolomite content. The calcium rich phases are due to the increased amount of calcium in the wood fuel.

\section{Deposit Samples}

Deposits were also generated in the EERC's DTF facility. A scanning electron microscopy point count (SEMPC) was performed on each of the deposits. This analysis gives an idea of the mineral transformations taking place during combustion. The results can also be used to "flag" potential problems that the burning of the tested fuel may cause.

The first sample tested was the Beulah lignite. This fuel is currently being fired at the State Penitentiary. The deposit formed was very loosely adhered to the deposit probe and was easily removed. An SEMPC analysis of the deposit indicated that most of the deposit material was calciumrich. The results of the SEMPC analysis are found in Table 10; only phases making up more than $1 \%$ of the deposit are reported in the table.

\begin{tabular}{lccc}
\multicolumn{5}{l}{ Table 10. Results of SEMPC Analysis on Deposits from Lignite, Lignite-Pallet } \\
Wood, and Lignite-Green Wood Blends, frequency $\%$ \\
\hline Mineral Phase & Lignite & Lignite-Tree Wood & Lignite-Wood Chips \\
\hline Calcium Oxide & 1.0 & 3.5 & 4.0 \\
Iron Oxide & 1.4 & 9.3 & 15.6 \\
Mixed Oxide-Rich & 2.1 & 7.5 & 8.0 \\
Mixed Sulfur-Rich & 3.1 & 2.2 & 1.2 \\
Calcite & 23.0 & 4.4 & - \\
Ankerite & 4.1 & - & - \\
Mixed Metal-Rich & 6.9 & - & - \\
Quartz & 1.7 & - & - \\
Albite & - & - & 1.2 \\
Anorthite & 1.0 & - & 2.8 \\
Montmorillonite & 1.0 & - & 1.2 \\
Pyroxene & 1.4 & - & 1.2 \\
Calcium Silicate & 4.8 & 2.2 & 4.4 \\
Spurrite & 1.0 & 2.2 & - \\
Mixed Silicon-Rich & 13.7 & 11.5 & 12.4 \\
Unknown & 26.1 & 54.4 & 44.0 \\
\hline
\end{tabular}

Both lignite-wood blends produced deposits similar to the deposit formed by firing $100 \%$ lignite. The deposits were again loosely adhered to the deposit probe and easily removed. The chemical composition of the deposits was similar with the exception of an increased amount of unknown phases. The unknown phases consist of mixed calcium aluminosilicates. The deposits had the following strengths: lignite, 19 psi; lignite-wood chips, 20 psi; and lignite-tree wood, 12 psi. 
A more detailed SEM analysis of the deposits revealed the material holding the deposit together. Figure 9 below is an SEM photomicrograph of the deposit formed by firing 100\% lignite coal, while Table 11 gives its morphology analysis for the identified points. The rest of the morphology data can be found in Appendix C.

Based on the results presented above, the addition of either wood sample tends to increase the overall size of fly ash particles. This result will aid in the collection of fly ash by particulate collection devices. This may be due to the assimilation of fine quartz particles into the deposit matrix, hence shifting the ash distribution.

The results of SEM analysis of the deposits indicate that the material holding the deposits together consists of a calcium aluminosilicate compound. This compound is formed by the

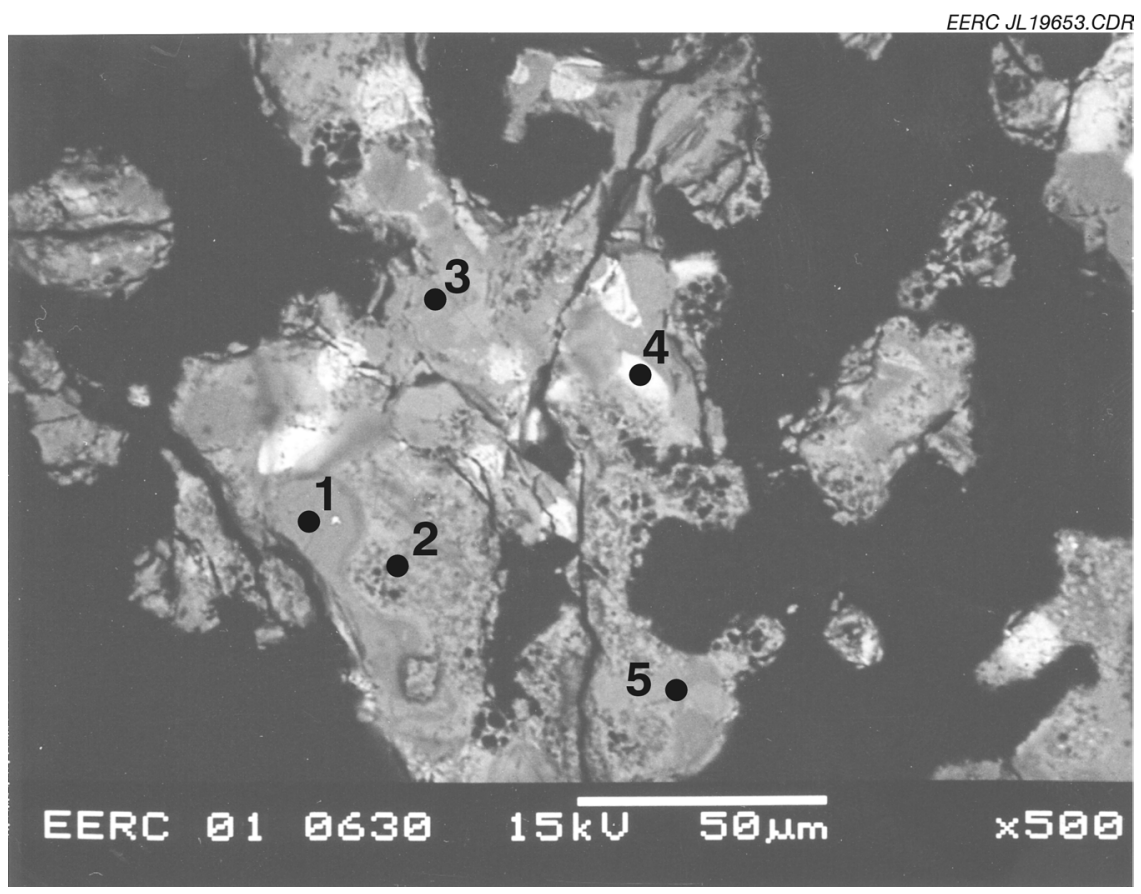

Figure 9. SEM micrograph of a deposit formed from Beulah lignite.

Table 11. Lignite Deposit Morphology Analysis Results

\begin{tabular}{lcrrrrrrr}
\hline Point & Description & $\mathrm{Na}$ & $\mathrm{Mg}$ & $\mathrm{Al}$ & $\mathrm{Si}$ & $\mathrm{S}$ & $\mathrm{Ca}$ & $\mathrm{Fe}$ \\
\hline 1 & Matrix & 0.4 & 26.3 & 5.0 & 6.6 & 1.8 & 43.4 & 16.2 \\
2 & Matrix & 3.9 & 3.6 & 5.8 & 32.6 & $\mathrm{ND}^{1}$ & 42.5 & 11.1 \\
3 & Matrix & 3.2 & 5.0 & 7.4 & 2.4 & 9.8 & 50.9 & 19.5 \\
4 & Bright particle & 1.4 & 1.5 & 1.6 & 2.1 & $\mathrm{ND}$ & 6.9 & 86.2 \\
5 & Matrix & 2.3 & $\mathrm{ND}$ & 4 & 37 & $\mathrm{ND}$ & 52.8 & 1.7 \\
\hline${ }^{1}$ Not detected. & & & & & & &
\end{tabular}


incorporation of calcite and dolomite-type fly ash particles reacting with silicate phases. The calcium likely originated in the organic portion of the fuel and is not evident in the CCSEM analysis of the fuel samples but can be recognized in the XRF data.

Some major differences seen between the three samples are as follows. All three fuels produce fly ash with iron oxide as a major phase. The iron oxide can be incorporated into the deposit matrix or can stay in the fly ash fraction. The $100 \%$ lignite fuel maintained most of the iron in the fly ash and not in the deposit. The iron being assimilated into the deposit may or may not have a long-term effect on the deposits characteristics. The lignite and lignite-wood chip samples had deposits with similar strengths (20 psi), while the lignite-tree wood sample had a much lower strength (12 psi). It is also interesting to note that the lignite-wood chips deposit grew at a slightly higher rate than the other two, the lignite-tree wood deposit having the lowest sticking potential.

The SEM analysis also indicates the possible potential for the lignite-wood chip deposit to produce slightly "nastier" deposits. The presence of anorthite, pyroxene, and increased calcium silicates lends one to believe a higher degree of sintering has occurred and possibly produced some crystalline phases. These types of deposits tend to have a higher strength and be harder to remove.

It is also important to note that the lignite has a high amount of iron sulfide compounds and all three samples have a high amount of alkali elements organically associated in all of the fuels. This combination is highly favorable to the formation of sulfate phases in portions of the boiler that have lower temperatures.

The two lignite biomass blends tested in this project should not severely decrease fireside performance. Blending with wood chips and tree wood shifts the particle-size distribution of fly ash to larger sizes. This will aid in fly ash collection. Emissions measured during the runs showed on average a $46 \%$ reduction in sulfur and a $33 \%$ reduction in $\mathrm{NO}_{x}$. Specific data are provided in Appendix C.

The deposits produced by a lignite-tree wood blend had characteristics that were slightly more favorable than the pure lignite or the lignite-wood chips blend. The favorable blend had a deposit that was less sintered, a lower crushing strength, and less potential to melt and produced crystalline phases and stronger deposits.

\section{Clinkering Potential for Grate-Fired Systems}

Combustion testing in the small grate-stoker combustion system focused on evaluating the propensity for low-viscosity slag development, which could induce clinker formation. The lignite and blends of $25 \%$ lignite- $75 \%$ tree wood and $25 \%$ lignite- $75 \%$ pallet wood by weight were fired in the bench-scale stoker system under conditions approximating those in the NDSP boiler. The blend level was selected to be in the range of what would be fired at the NDSP facility.

The lignite, tree wood, and wood chip samples were ground and sieved to provide material suitable for introduction into the auger of the combustor. The lignite was crushed to $! 3 / 8 "+1 / 8 "$, and the tree wood and wood chips ground and sieved to ! 3/8" + 1/8". 
At the start of each test, a bed of the fuel was placed on the grate and ignited with a propane torch. Once the fuel bed was ignited, the fuel feed rate and combustor draft were adjusted to maintain stable steady-state burning. The individual tests were run for 4 hours for the lignite, 3.5 hours for the $25 \%$ lignite $-75 \%$ tree wood blend, and 4 hours for the $25 \%$ lignite- $75 \%$ wood chip blend. The fuel feed was then terminated, the remaining fuel on the grate allowed to burn out and cool, and the residual ash on the grate inspected for evidence of slagging and clinker formation.

Observations of the ash formed by the lignite coal itself indicated that although numerous ash agglomerates resembling clinkers had formed, these were very friable and crumbled when touched. A few $1 / 4 "$ to $3 / 8 "$ agglomerates were harder and were collected for subsequent examination. Photographs are provided in Appendix C.

Observations during the test of the $25 \%$ lignite $-75 \%$ tree wood blend noted that the difference in fuel density resulted in the lignite being sparsely dispersed in the tree wood fuel and that only very infrequently would two coal particles be in contact on the grate. Effectively, ash from the coal particles only contacted ash from the biomass, without larger agglomerations forming from interactions between coal ash particles. The temperature during the test was somewhat lower, because of the lower heating value of the biomass. The great majority of the ash remaining at the conclusion of the test was very fine, with no agglomerations formed as had occurred during the test with the lignite coal alone. A few small firm agglomerates were found on the grate, although these were much smaller than those from the test of the lignite coal, being only approximately $1 / 8$ " in size. Similar results were seen for the $25 \%$ lignite $-75 \%$ wood chips blend.

The clinkers produced during testing were mounted in epoxy and cross-sectioned for examination of their morphology and chemistry using a scanning electron microscope (SEM).

Appendix C-19 shows typical cross sections of the 100\% lignite, the $25 \%$ lignite- $75 \%$ tree wood, and the $25 \%$ lignite- $75 \%$ pallet wood, respectively. Indicated in the figures are major chemical constituents for selected areas analyzed. The clinker deposits are quite porous, which is consistent with the observation of the high friability of the clinkers during the combustion tests.

Appendix C-20 compares the predicted ash composition based on the bulk inorganic chemistry of the fuels with the actual average chemical compositions determined during the SEM morphological examination. The clinkers formed from the $100 \%$ lignite fuel were significantly enriched in iron, with corresponding depletion of silica, sulfur, magnesium, sodium, and potassium. In contrast, although the $25 \%$ lignite- $75 \%$ tree wood and $25 \%$ lignite- $75 \%$ pallet wood blends are also enriched in iron, there is also a large enrichment of sulfur. Of interest is the increased sulfur retention, although alkali and alkaline-earth species $\left(\mathrm{CaO}, \mathrm{MgO}, \mathrm{Na}_{2} \mathrm{O}\right.$, and $\left.\mathrm{K}_{2} \mathrm{O}\right)$, which might be expected to capture sulfur, are depleted in the blend clinkers. The association of the sulfur appears to be primarily with iron either as a sulfate or sulfide, although some areas analyzed indicate the presence of sulfur in association with alkali and alkaline-earth elements.

It would appear that under the combustion conditions used, much of the alkali and alkalineearth species in the biomass form a fine light ash which is entrained by the air flow through the grate and removed without interacting with the iron and other lignite-derived ash minerals. Even with the 
lignite ash, the lighter material seems to be removed, leaving the denser, iron-rich ash on the grate. This iron-rich material also appears to be quite effective at sulfur capture for the lignite-biomass blends. Although the clinkers formed were friable under the combustion conditions used, a sufficiently higher fuel bed temperature could result in more problematic grate clinkers because of the high iron and sulfur content.

The bench-scale stoker test results showed that the lignite coal alone formed larger agglomerates than did either of the two blends tested. The agglomerates of the lignite coal alone were also larger and harder than the ash from the blends, although the lignite coal agglomerates were generally very weak. The tests indicate that the blending of either the tree wood or wood chips with the lignite will not produce increased clinker formation and may even reduce clinker formation at high biomass blend levels. This is consistent with the low ash content of the biomass and the predictions of the PCQUEST and FACT calculations.

\section{TASK 4 - ENVIRONMENTAL ISSUES}

\section{Changes in Boiler Emissions and Their Effect on Permitting}

\section{Air Emissions}

Switching fuel from coal to biomass or a blend of coal and biomass typically has a beneficial impact with regard to stack emissions. Most biomass sources are low in sulfur and result in substantially lower $\mathrm{SO}_{2}$ emissions for the same fuel input. Wood wastes typically have lower ash content, resulting in lower amounts of uncontrolled particulate emissions; however, the particulates generated from burning biomass are typically finer than coal ash and may or may not lead to lower stack emissions. When burned wet, biomass will also reduce flame temperatures during combustion and can produce lower levels of $\mathrm{NO}_{\mathrm{x}}$.

The NDSP operates its current boilers under North Dakota Department of Health (NDDH) Air Pollution Control Permit to Operate Number F83007. Condition 7.C of the permit sets the stack emission limits for the Zurn spreader stoker at $0.52 \mathrm{lb} / \mathrm{MMBtu}$ for particulate matter (PM), an opacity of $20 \%$, and $3.0 \mathrm{lb} / \mathrm{MMBtu}$ for sulfur dioxide. The coal-fired boiler currently meets the stack particulate emissions and opacity requirements. The boiler modifications that are recommended to accommodate firing the blend of coal and wood wastes (primarily feed method, grate design, and overfire air control) are expected to reduce the amount of PM that leaves the boiler. Therefore, it is anticipated that particulate emissions and opacity will not change substantially from the current level. Current $\mathrm{SO}_{2}$ emissions, based upon U.S. Environmental Protection Agency (EPA) AP-42 Emission Factors and the level of sulfur in the coal $(0.74 \%)$ are estimated to be $1.4 \mathrm{lb} / \mathrm{MMBtu}$. The lower sulfur content in the blend $(0.32 \%)$ would reduce the estimated $\mathrm{SO}_{2}$ emissions to $0.6 \mathrm{lb} / \mathrm{MMBtu}$.

Of more importance to this feasibility study is Condition 7.J, which deals with alterations, modifications, or changes. This condition states that "any alteration, rebuilding, repairing, expansion, change in the method of operation, or change of location of the source which results in the emission of an additional type or greater amount of air contaminants or which results in an increase in the 
ambient concentration of any air contaminant must be reviewed and approved by the Department prior to the start of such alteration, rebuilding, repairing, expansion, change in method of operation, or change of location." The boiler modifications proposed are not expected to change the ambient concentration of any pollutant and should reduce ambient $\mathrm{SO}_{2}$ concentrations. Since only untreated wood will be accepted as fuel, no new air contaminants should be emitted. However, changing the annual hours of operation from the equivalent of 1095 to 8322 will increase the total amount of air contaminants emitted each year. Table 12 presents the current and expected annual uncontrolled emissions from the Zurn boiler currently in operation at the State Penitentiary. Of primary concern are the $\mathrm{SO}_{2}$ and $\mathrm{NO}_{\mathrm{x}}$ emissions. PM is controlled by the existing ESP, so the factors listed here represent an estimate of PM entering the ESP, rather than the total emitted.

A primary factor in determining whether the proposed modifications and change in operation trigger reclassification of the Zurn boiler as a new source are its emissions relative to Title V and Prevention of Significant Deterioration (PSD) limits. Subsection b of Section 3 of Section 33-15-1402 of the North Dakota Air Pollution Rules lists exceptions to those cases where boiler modifications an/or changes in operating procedures require establishment of a new source. Since the proposed changes will result in increasing the firing rate to the boiler's rated capacity, the total hours of annual operation will increase significantly. The two appropriate conditions to be considered that exclude classification of a new source for Title V or PSD are:

- If increasing the firing rate does not exceed the operating design capacity of the source and it is not limited by a permit condition, reclassification to Title V or PSD may be avoided.

- If increasing the hours of operation is not limited by a permit condition, reclassification to Title V or PSD may be avoided.

Therefore, provided the changes will not trigger a limitation executed by the existing permit, or by state and federal standards, the unit should not require classification as a new source. As shown in Table 12, the triggers for permit reclassification are $250 \mathrm{tn} / \mathrm{yr}$ of a single pollutant based on PSD and $100 \mathrm{tn} / \mathrm{yr}$ based on Title $\mathrm{V}$. The annual emissions of $\mathrm{SO}_{2}$ are expected to increase from the current level of approximately 29 to $94 \mathrm{tn} / \mathrm{yr}$ for the base case (75-25 wood-coal blend at a 95\% capacity factor). $\mathrm{NO}_{\mathrm{x}}$ annual emissions are expected to increase from 7.7 to $53 \mathrm{tn} / \mathrm{yr}$. The base case is below these triggers for all pollutants. The only scenario that may require reclassification of the boiler under Title $\mathrm{V}$ is the case where the amount of biomass available is less than the optimal 75-25 wood-coal blend and the unit is fired at 95\% capacity. At the $95 \%$ capacity factor, Title V restrictions would kick in at a blend ratio of 70-30 wood-coal blend.

\section{Required Air-Related Permit Actions}

Air permit actions are minimal for the case where the annual emissions are maintained below the trigger levels for Title V (100 tn/yr per pollutant). As stated above, this is the case for all scenarios using the 75-25 wood-coal blend. If annual pollutant levels do not trigger Title V, the State Penitentiary will be required to inform the NDDH in writing of the proposed changes, including the expected emissions under the new operating scenario. Upon review of this letter, the NDDH will issue a response granting authorization to proceed with the planned modifications. This 
Table 12. Emission Estimates for Given Blends from the State Correctional Center

\begin{tabular}{|c|c|c|c|c|c|c|}
\hline Common Factors & & & & & & \\
\hline Design Feed Rate, lb/hr & 4,605 & & & & & \\
\hline Current Coal Usage, $\mathrm{tn} / \mathrm{yr}$ & 2,600 & & & & & \\
\hline Design HHV, Btu/lb & 7,440 & & & & & \\
\hline Design Heat Input, Btu/hr & 34261200 & & & & & \\
\hline Design Input, MW (check factor) & 10 & & & & & \\
\hline Current Availability & $12.9 \%$ & & & & & \\
\hline HHV New Coal, Btu/lb & 6,700 & & & & & \\
\hline HHV Wood, Btu/lb & 8,274 & & & & & \\
\hline Coal S & 0.74 & & & & & \\
\hline Wood S & 0.18 & & & & & \\
\hline Coal Ash & 5.9 & & & & & \\
\hline Wood Ash & 1.9 & & & & & \\
\hline Emission Factors for Overfed Stoke & A AP-42 & & & & & \\
\hline & $\mathrm{lb} /$ ton coa & & & & & \\
\hline PM from Boiler (factor $\times$ ash) & 8 & & & & & \\
\hline PM from ESP (factor $\times$ ash) & 0.07 & & & & & \\
\hline $\mathrm{SO}_{2}($ factor $\times \mathrm{S})$ & 30 & & & & & \\
\hline $\mathrm{NO}_{\mathrm{x}}$ & 5.8 & & & & & \\
\hline Caluclated Uncontrolled Emissions & & & & & & \\
\hline PM from Boiler, $\mathrm{tn} / \mathrm{yr}$ & 61 & & & & & \\
\hline PM with ESP, $\mathrm{tn} / \mathrm{y}$ & 1 & & & & & \\
\hline $\mathrm{SO}_{2}, \mathrm{tn} / \mathrm{yr}$ & 29 & & & & & \\
\hline $\mathrm{NO}_{\mathrm{x}}, \mathrm{tn} / \mathrm{yr}$ & 8 & & & & & \\
\hline Input for New Scenarios* & 1 & 2 & 3 & 4 & 5 & 6 \\
\hline Pct Coal in Blend & $\overline{0.25}$ & $\overline{0.25}$ & 0.3 & $\overline{0.25}$ & 0 & 1 \\
\hline Pct Biomass in Blend & 0.75 & 0.75 & 0.7 & 0.75 & 1 & 0 \\
\hline Availability & 0.95 & 0.74 & 0.95 & 1 & 0.95 & 0.95 \\
\hline Coal Feed, lb/hr & 1278 & 1278 & 1534 & 1278 & 0 & 5114 \\
\hline Biomass Feed, lb/hr & 3106 & 3106 & 2899 & 3106 & 4141 & 0 \\
\hline Coal Feed, $\operatorname{tn} / \mathrm{yr}$ & 5319 & 4144 & 6383 & 5599 & 0 & 21278 \\
\hline Biomass Feed, $\mathrm{tn} / \mathrm{yr}$ & 12922 & 10066 & 12061 & 13603 & 17230 & 0 \\
\hline Calculated Uncontrolled Emissions & & & & & & \\
\hline PM from Boiler, $\mathrm{tn} / \mathrm{yr}$ & 224 & 174 & 242 & 236 & 131 & 502 \\
\hline PM with ESP, tn/y & 2 & 2 & 2 & 2 & 1 & 4 \\
\hline $\mathrm{SO}_{2}, \mathrm{tn} / \mathrm{yr}$ & 94 & 73 & 103 & 99 & 47 & 236 \\
\hline $\mathrm{NO}_{\mathrm{x}}, \mathrm{tn} / \mathrm{yr}$ & 53 & 41 & 53 & 56 & 50 & 62 \\
\hline$\underline{\text { Triggers for Permit Reclassification }}$ & & & & & & \\
\hline & $\underline{\mathrm{PSD}}$ & & $\underline{\text { Title V }}$ & & & \\
\hline $\mathrm{PM}_{10}, \mathrm{tn} / \mathrm{yr}$ & 250 & & 100 & & & \\
\hline $\mathrm{SO}_{2}, \mathrm{tn} / \mathrm{yr}$ & 250 & & 100 & & & \\
\hline $\mathrm{NO}_{\mathrm{x}}, \mathrm{tn} / \mathrm{yr}$ & 250 & & 100 & & & \\
\hline Average Sulfur of Blend & 0.32 & 0.32 & 0.348 & 0.32 & & \\
\hline * 1 Base case for retrofit. & & & & & & \\
\hline 2 Change availability with cons & educe biom & 10,000 & & & & \\
\hline 3 Change blend with constant a & educe biom & 10,000 & & & & \\
\hline 4 Change availability with cons & educe $\mathrm{SO}_{2}$ & han 10 & & & & \\
\hline 5 Emissions for $100 \%$ biomass & bility. & & & & & \\
\hline 6 Emissions for $100 \%$ coal at 9 & & & & & & \\
\hline
\end{tabular}


authorization would be expected to be granted within 1 to 2 weeks. The NDDH will require stack testing to verify the estimated emission levels once boiler modifications are complete. A final permit modification will be granted based upon the results of these stack tests. All existing conditions of Permit F83007 will be expected to remain in effect.

If the recommendation of this feasibility study and the plans of the State Penitentiary are to operate the boiler at a $95 \%$ capacity factor at a blend ratio of $70 \%-30 \%$ wood-coal or lower, then a Title V permit will be required. Procedures for obtaining a Title V Permit to Construct and Permit to Operate are given in Section 33-15-14 of the North Dakota Air Pollution Rules. An application for a permit to construct requires 30 days for review by the state and another 45 days for review by the EPA. A Title $\mathrm{V}$ permit requires additional monitoring, recording, and record keeping for $\mathrm{NO}_{\mathrm{x}}$, $\mathrm{CO}, \mathrm{PM}$, and $\mathrm{SO}_{2}$. The $\mathrm{NO}_{x}$ and $\mathrm{CO}$ monitoring could be met using a portable analyzer with testing performed every 6 months. This is currently done at the University of North Dakota Steam Plant to partially meet its Title $\mathrm{V}$ requirements. $\mathrm{SO}_{2}$ emissions can be calculated based on an analysis of the sulfur in the fuel. For coal, this is typically done on a per shipment basis. An acceptable method would need to be devised to deal with a potentially wide variety of sources for wood waste. PM is periodically checked using on-site personnel who are trained and certified to estimate the opacity of the gases leaving the stack of the boiler. While the Title $\mathrm{V}$ permit requirements will add to the work load of operations/supervisory staff at the State Penitentiary, these requirements should be minimal both in terms of staffing and cost. Therefore, because the economical impact of Title $\mathrm{V}$ requirements are minimal, they should not be used as a criteria for selecting the optimal blend ratio or capacity factor.

\section{Solid Waste Considerations}

The State Penitentiary is not required to have a solid waste permit under its current mode of operation. Small facilities are typically allowed to dispose of their ash and other residues directly to the landfill. Under the current mode of operation, approximately $150 \mathrm{tn} / \mathrm{yr}$ of ash is generated that must be disposed of at the landfill. Under the baseline scenario, this would increase to approximately $550 \mathrm{tn} / \mathrm{yr}$ and still would be considered a small amount not requiring a solid waste permit.

The current mode of operation at the State Penitentiary is to stockpile ash for a considerable amount of time prior to hauling the ash to the landfill. Under the new scenario, it is recommended that the ash be hauled to the landfill on a monthly basis.

\section{Water Quality/Storm Water Runoff}

Under the proposed modified operations, wood waste will be received with provisions for some outside storage of unprocessed wood. Once the wood is dried and processed (chipped), it is stored inside the feed bins until it is consumed in the boiler. No processed material will be stored with exposure to the elements. Therefore, since no processed fuel will be stored outside, no special permitting is required. Also, ash is planned to be stored on-site in closed vessels, eliminating the need for a leachate water quality permit. 
If processed fuel and/or ash is stored exposed to the elements, the type of material to be stored will need to be identified, along with the potential material in the runoff. Based on this information, a pollution prevention plan will need to be prepared. Sampling will be required once or twice per year for biological oxygen demand, chemical oxygen demand, nitrates, and others based upon the material that is being stored. The NDDH will set permit discharge levels.

\section{Transfer Station Permitting}

Under some scenarios, a site receiving a waste material must obtain a transfer station permit. Recyclable/reuse material is typically granted an exemption, since this material, if recycled or reused, is not itself a waste. In the case of the proposed project with the State Penitentiary, an exemption from transfer station permitting is expected since the proposed wood is not a true waste. Additionally, many states encourage this type of operation since it significantly reduces the burden on the landfill.

\section{Economic Considerations Relative to Permitting}

An important aspect for economic consideration of cogeneration projects is the value of producing excess electricity to put back on the grid versus internal use of all electricity generated. A utility company is required to buy electricity from a Qualifying Facility (QF) as defined under 18 CFR, Part 292. The question becomes whether the profits generated from this sale offset the additional costs associated with the sale.

Typically, utility companies will have rate agreements that are applicable for facilities like the State Penitentiary that would not be dispatchable and would provide energy and capacity on an "as available" basis. For this type of facility, the utility would pay the avoided cost of producing electricity. This avoided cost for utilities in North Dakota is rather low, approximately $\$ 0.013$ to $\$ 0.175 / \mathrm{kWh}$. The higher price is typical of peaking power, with the lower representing off-peak pricing. Both rates would be specified in an agreement including a definition of peak and nonpeak hours. In addition, a nominal metering charge would be applied.

To ensure the reliability and safety of the electrical grid, the utility will require a number of provisions to be met prior to entering into an agreement with a QF. The most important in terms of the overall economic viability of a project are the requirements that the QF install metering and switchgear required for synchronous power transmission onto the grid. The cost of this equipment in many cases more than offsets any anticipated profits from power sales.

\section{TASK 5 - ENERGY PRODUCTION ASSESSMENT}

Several options were investigated for the coproduction of electricity and heat for the NDSP. The options primarily center on the application of steam turbines and their relationship to the existing thermal and electrical loads. The physical and economic constraints that apply to the production of energy are as follows: 
1. Electric power production must remain captive to achieve significant return on investment.

2. Existing thermal loads must be met at current steam conditions (100 psig saturated vapor). Lowering or raising steam pressure is possible, but was not considered because of the uncertainty for adequate alternative pressures to meet flow and equipment requirements.

3. Boiler output is limited to $200 \mathrm{psig}$ saturated vapor and $25,000 \mathrm{lb} / \mathrm{hr} @ 72 \%$ efficiency.

Energy use for the NDSP was obtained from monthly billing records. Average monthly loads were computed and used to determine a baseline for the energy production assessment. Figures 10 and 11 summarize the load profiles for electricity and thermal energy.

Options included considering extraction, condensing, back pressure, and small turbines applied to distributed pressure-reducing stations. The following describes the considerations used to determine the appropriate cogeneration configuration:

1. Extraction turbine consideration - Although a single extraction turbine could provide both back pressure to the system and condense auxiliary steam for electricity production, the cost was prohibitive. Separate condensing and back-pressure turbines can be purchased for 2.5 times less than the cost of a single extraction turbine. Therefore, one condensing turbine and one back-pressure turbine were chosen to provide power. Both turbines can be operated in either mode, which provides good redundancy for the power plant and increases availability.

2. It was discovered that 100 psig steam is produced and distributed to pressure-reducing stations throughout the facility. The pressure is reduced to $15 \mathrm{psig}$ before being used. Small pressure-reducing turbines were investigated to apply to this otherwise lost energy.

Performance data were obtained from Dresser Rand Corporation for the turbines. Quotations are included in the equipment specifications in Appendix B for the steam turbines. Performance data for the turbines are as follows. The condensing turbine follows a performance curve provided in Figure 12. Since the back-pressure turbine contributes only a small portion of the total electricity, the performance was calculated using a straight isentropic efficiency of $35 \%$. The performance of the small pressure reduction turbines is $45 \mathrm{lb} / \mathrm{hr}-\mathrm{kW}$.

The configuration of the system was modeled and is provided in Figure 13. The system is designed to provide consistent steam production year-round at 25,000 lb/hr, $200 \mathrm{psig}$ saturated steam. A single 200 psig header supplies both the back pressure and condensing turbine. A back pressure of $100 \mathrm{psig}$ is maintained for the system, and the condensing turbine exhausts at $20 \mathrm{psig}$. The pressure-reducing turbines were not modeled; however, calculations were performed separately and added later. The model was used to calculate average monthly performance of the system based on various thermal load requirements. The results of the calculations are provided in Tables 13 and 14, and detailed mass and energy balances are included in Appendix D. 


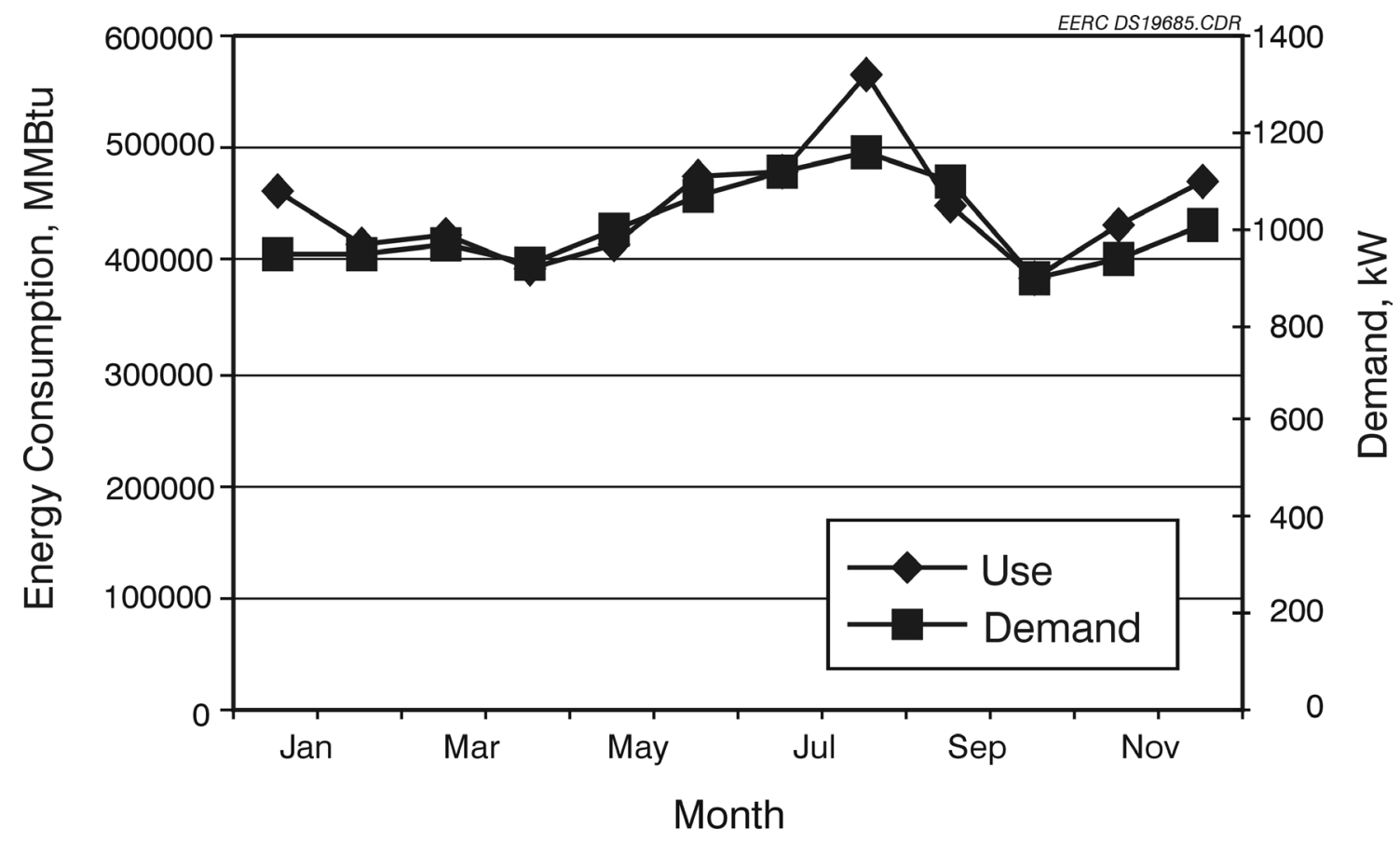

Figure 10. Electricity load profile.

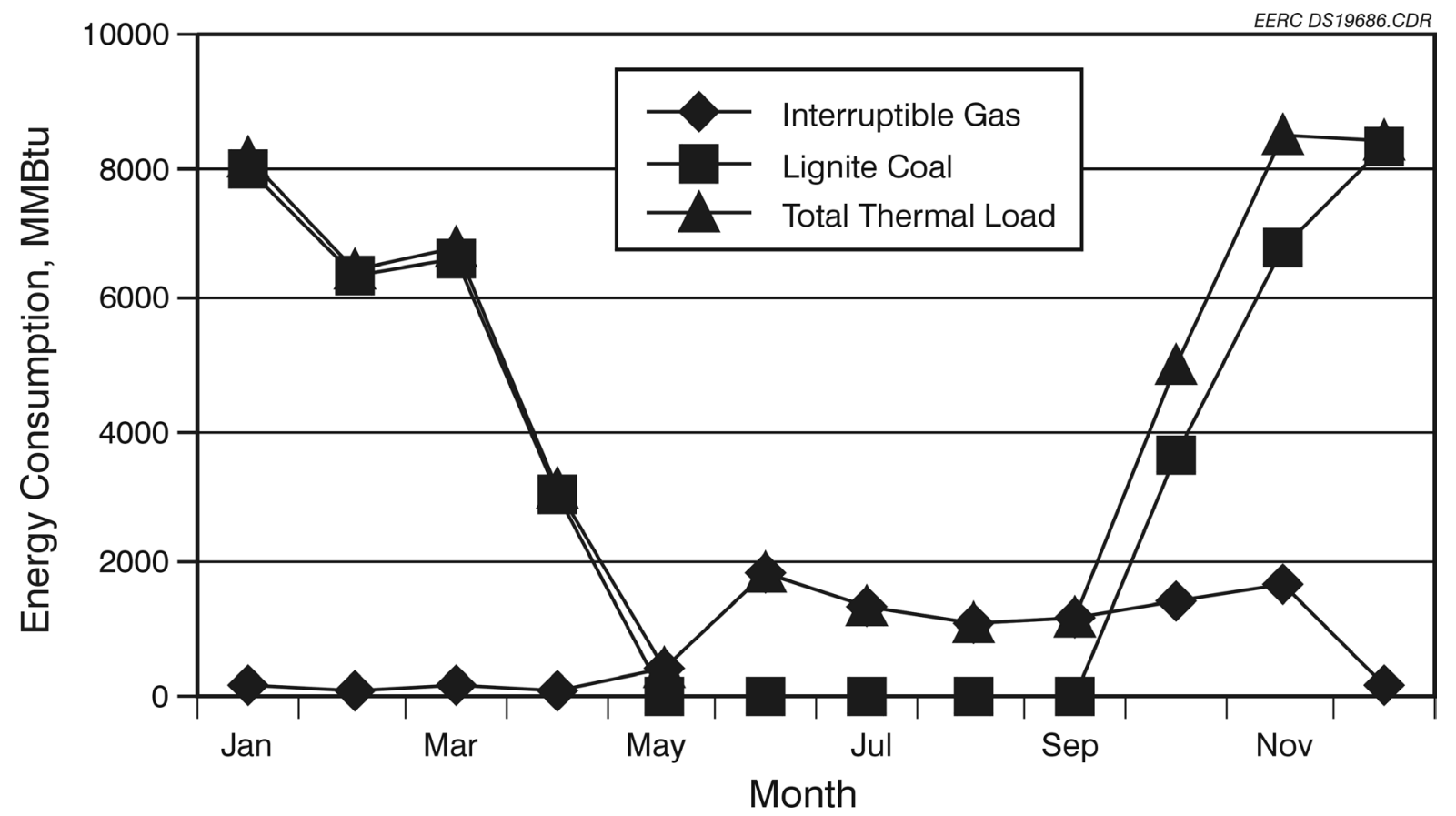

Figure 11. Energy consumption profile. 


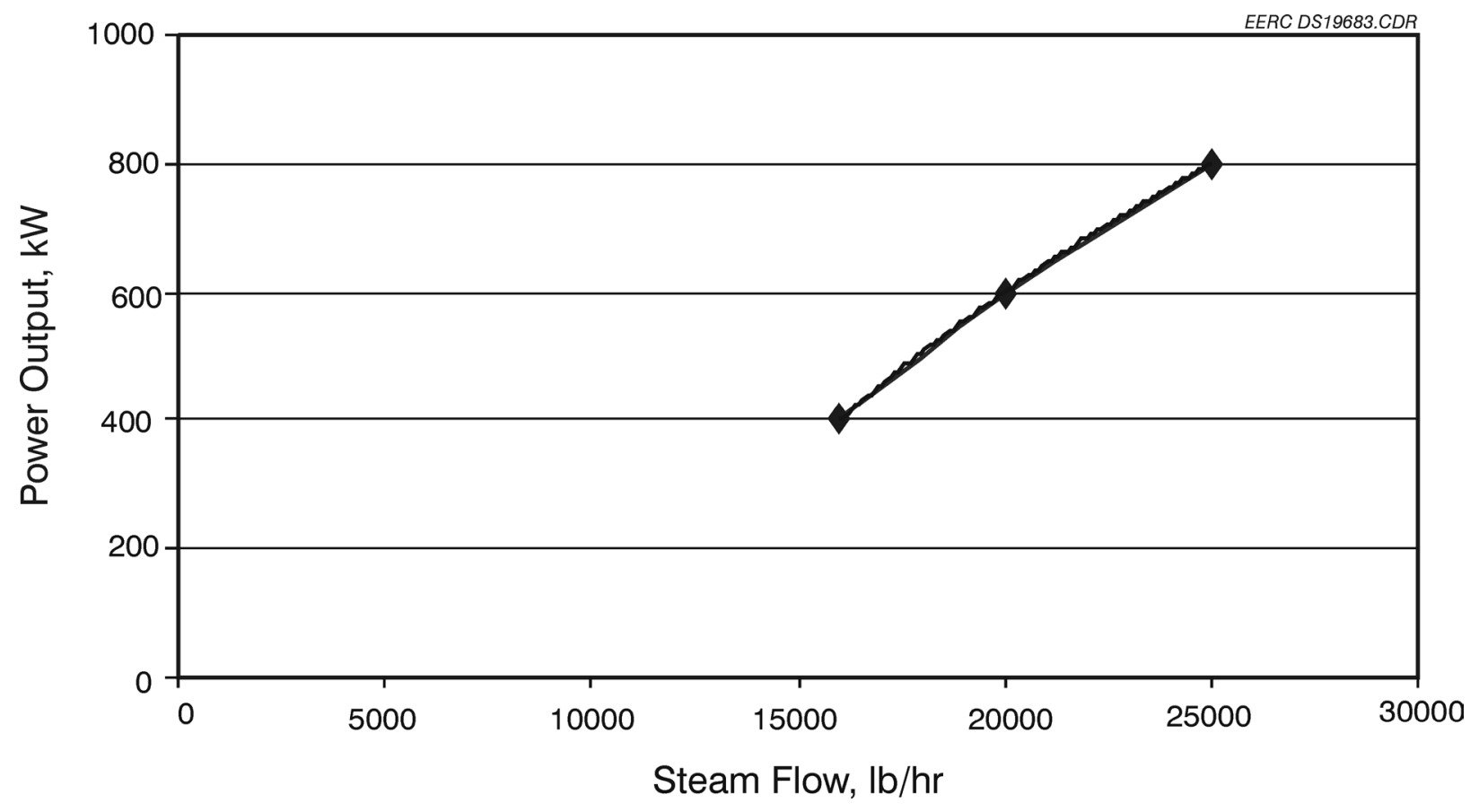

Figure 12. Condensing turbine performance.

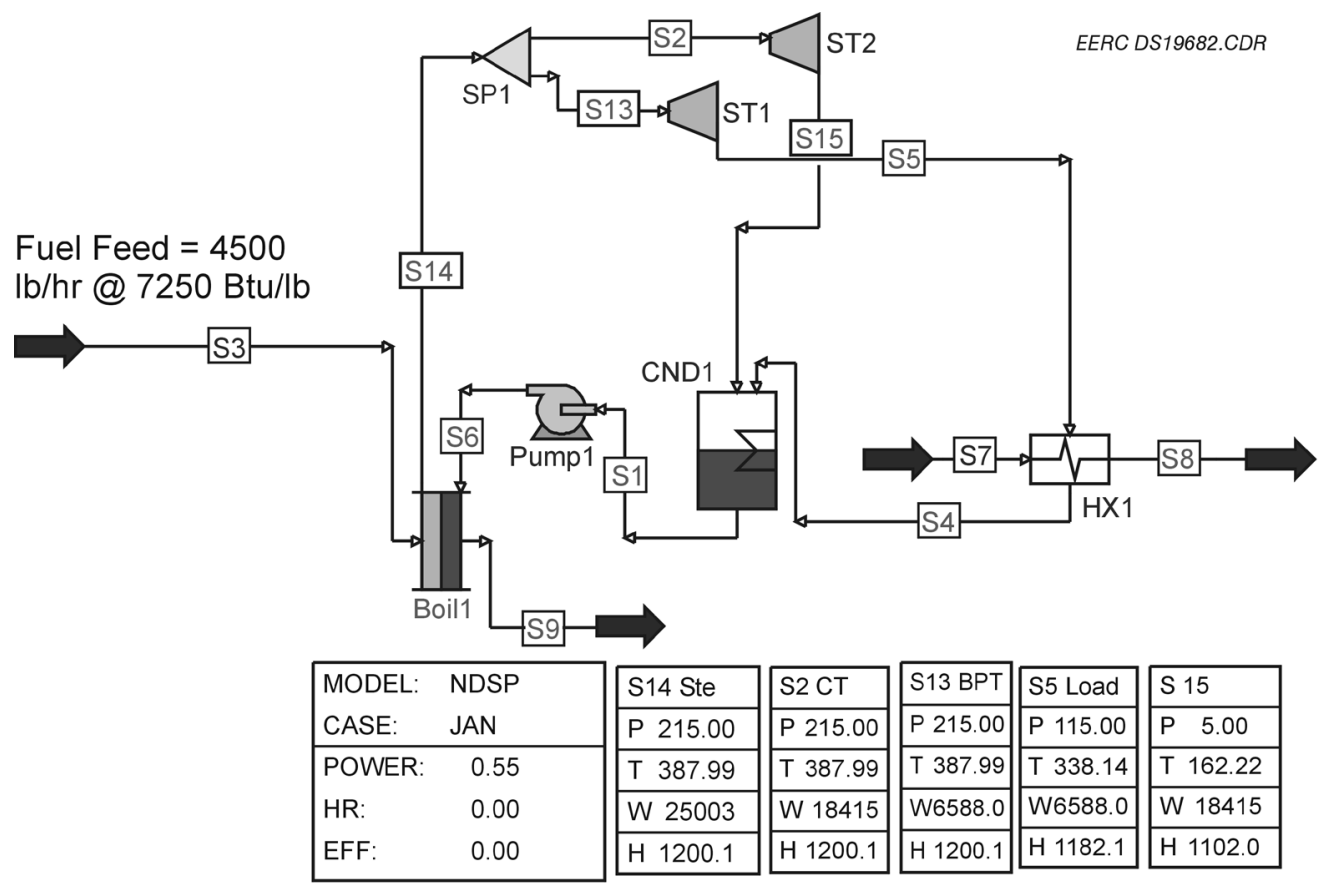

Figure 13. Energy production model, process flow diagram. 
Table 13. Monthly Electrical Generation

\begin{tabular}{|c|c|c|c|c|}
\hline \multicolumn{3}{|c|}{ Electrical Generation, $\mathrm{kWh}$} & Parasitic Loss & $15 \%$ \\
\hline Month & $\mathrm{CT}$ & $\mathrm{CT}+\mathrm{BPT}$ & $\mathrm{CT}+\mathrm{BPT}+\mathrm{PRTs}$ & Net Power \\
\hline$\overline{\text { Jan }}$ & 321846 & 353840 & 399922 & 339934 \\
\hline Feb & 386359 & 411608 & 447977 & 380780 \\
\hline Mar & 378869 & 405487 & 443826 & 377252 \\
\hline Apr & 481163 & 493488 & 511240 & 434554 \\
\hline May & 570011 & 571628 & 571966 & 486171 \\
\hline Jun & 521669 & 529174 & 530741 & 451130 \\
\hline Jul & 547425 & 552775 & 553892 & 470808 \\
\hline Aug & 553129 & 557537 & 558457 & 474689 \\
\hline Sep & 551947 & 556550 & 557511 & 473884 \\
\hline Oct & 438053 & 457860 & 486391 & 413433 \\
\hline Nov & 314406 & 347876 & 396085 & 336672 \\
\hline Dec & 315932 & 349100 & 396875 & 337344 \\
\hline & & & 5854883 & 4976651 \\
\hline
\end{tabular}

Table 14. Monthly Average Peak Thermal Load Case

\begin{tabular}{lr}
\hline $\begin{array}{l}\text { System Performance for November Average Month Heat Load } \\
\text { (based on billing) }\end{array}$ \\
\hline Firing Rate & $37,775 \mathrm{kBtu} / \mathrm{hr}$ \\
Condensing Turbine Output & $431 \mathrm{~kW}$ \\
Back-Pressure Turbine Output & $46 \mathrm{~kW}$ \\
Total Power Output & $477 \mathrm{~kW}$ \\
Pumping Requirement & $5.5 \mathrm{~kW}$ \\
Other Parasitic Loads 5\% & $24 \mathrm{~kW}$ \\
Net Power Out & $447 \mathrm{~kW}$ \\
Heat Load & $9,184 \mathrm{kBtu} / \mathrm{hr}$ \\
System Energy Efficiency & $28 \%$ \\
\hline
\end{tabular}

An analysis was performed to determine the cost-effectiveness of the back-pressure turbine since its output is marginal as shown in Figure 14. A relative simple payback analysis was used to compare costs, as shown in Table 15.

New and used turbines can be procured for the project, and their costs were taken into consideration. The condensing turbine, whether purchased new or used, appears to have an attractive payback. The back-pressure turbine payback is higher by a factor of 4 to 10 years. As a percentage of project investment, the cost of acquiring a back-pressure turbine and the effect on overall project payback were considered. If we are targeting a 7-year payback period, it appears that the purchase of a used back-pressure turbine will only slightly impact the total project economics. Therefore, the benefits of turbine redundancy and flexibility are worth the marginal economics of purchasing a used back-pressure turbine. 


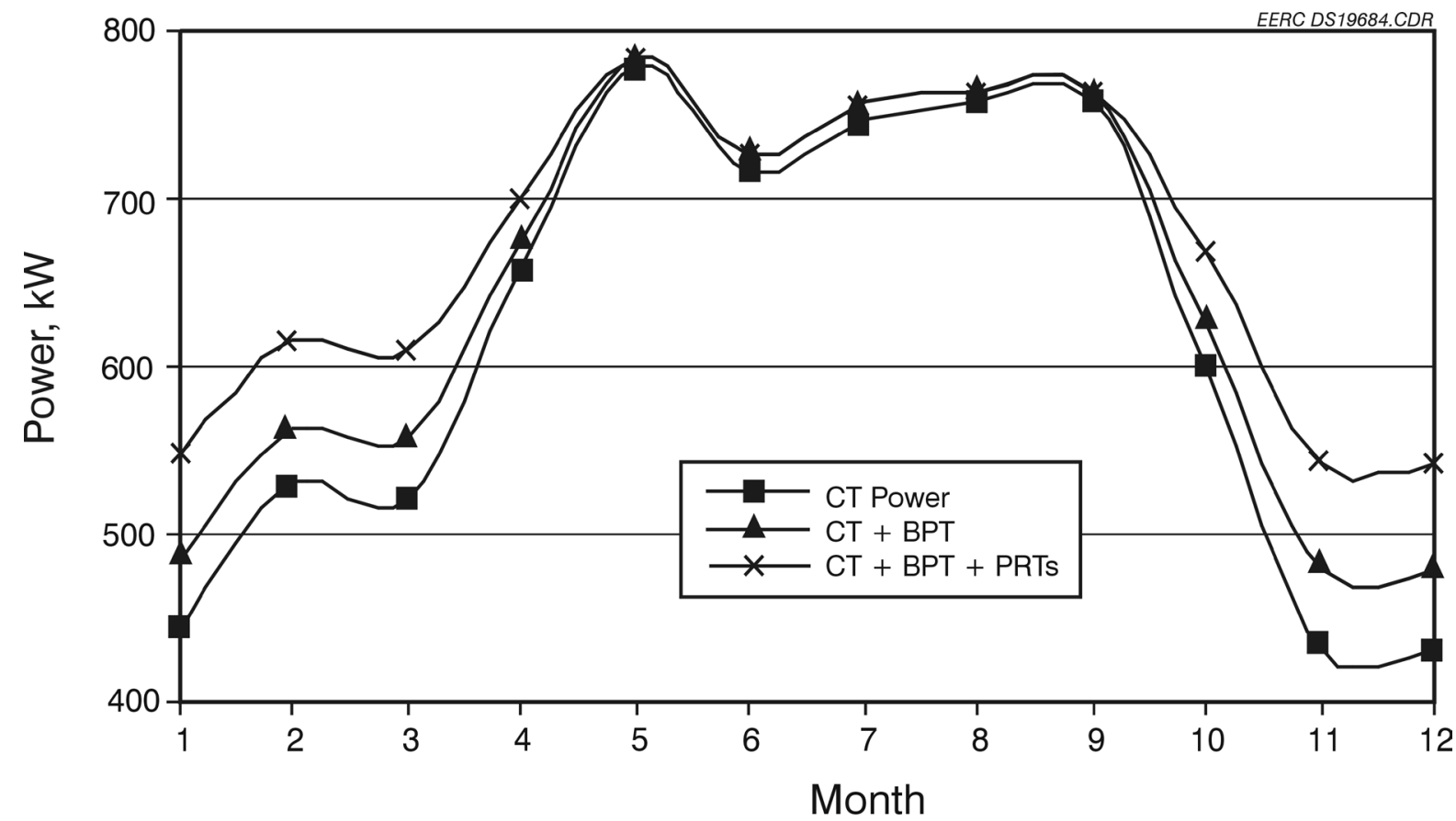

Figure 14. Contribution of back-pressure turbine to load.

Table 15. Relative Payback Analysis for the Back-Pressure Turbine

\begin{tabular}{lllc}
\hline Simple Payback Analysis & & \multicolumn{2}{l}{ Simple Payback as \% of Project Investment } \\
Condensing Turbine & & Total Project Cost & $\$ 1,800,000$ \\
Cost New & $\$ 200,000$ & CT New & $11 \%$ \\
Cost Used & $\$ 50,000$ & CT Used & $3 \%$ \\
Payback New & 1.3 years & BPT New & $6 \%$ \\
Payback Used & 0.19 years & BPT Used & $3 \%$ \\
& & & Effect of Purchase on Payback \\
Back-Pressure Turbine & & Total Project Payback Period, 10 years \\
Cost New & $\$ 110,000$ & CT New & 11.6 months \\
Cost Used & $\$ 50,000$ & BPT New & 1.65 months \\
Payback New & 11 years & Benths \\
Payback Used & 5.0 years & Used BPT & \\
& & & Total Project Payback Period, 7 years \\
& & CT New & 7.6 months \\
& & BPT New & $! 2.85$ months \\
& & Used BPT & 0.68 months \\
\hline
\end{tabular}




\section{TASK 6 - ENGINEERING ECONOMIC ANALYSIS}

An engineering economic analysis was performed to assess the viability of the proposed project, determine the factors that are most critical to the success of the project, and determine alternative cases that may improve the likelihood of economic success. Presented here are the results of the economics, a discussion of the calculations and assumptions, and potential alternative economic scenarios.

The base case economic scenario was conceived from the following calculations and assumptions described in Figure 15. The peak load (1) is $784 \mathrm{~kW}$, and this is calculated from the highest average monthly electrical production primarily based on the potential output from the condensing turbine in the summer months. Gross electrical and net electrical production was calculated from the average monthly projected power outputs from Task 5. A load factor of 1 , availability of $90 \%$, and a parasitic loss of $15 \%$ were applied. It is reasonable to assume that availability could be $90 \%$, leaving a 1 -month downtime because two steam turbines will be installed. Both turbines will have the capability of operating in either condensing or back-pressure mode, and while one is down, the other could be operated a full output. Steam output was assumed at $25,000 \mathrm{lb} / \mathrm{hr}$, which is the continuous rating of the NDSP boiler. It was assumed that $75 \%$ biomass will be fired with $25 \%$ coal. This ratio tends to be the most economically viable and within reason based on the resource assessment. The best scenario is to fire 100\% biomass; however, resources may not be available to support this level of biomass firing, and the flexibility of some regular coal supply is necessary to ensure that in an emergency enough coal will be available for heating purposes.

Cash flow calculations for the base case are presented in Figure 16 and discussed. The costs are shown as current facility costs, cost reductions with cogeneration, and cost additions due to cogeneration, and debt service. The electricity cost includes demand and service charges. Natural gas and electricity are escalated at 3\% per year, primarily because the state of North Dakota allows a 3\% increase on utility budgets at state agencies and previous studies presented to the state for energy efficiency projects have used the same assumptions. Coal is escalated at $1.5 \%$, based on the same criteria and inflation at $2.7 \%(6)$. An alternative case is presented later where escalations are in line with energy information administration predictions of close to $0 \%$ (7). All current costs were provided by the NDSP. Cost reductions are primarily achieved by offsetting electricity costs and natural gas. Cost additions occur because of increased personnel requirements, specified by the NDSP, and operation and maintenance specified by the equipment manufacturers. Also, increased chemical usage and ash disposal are expected. The debt service is based on $5.05 \%$ bond financing, which is currently available. The results show a negative savings in the first few years; however, advanced payments from increased savings in the later years can be used to pay off debt early.

The results of the base case economic analysis show how a $\$ 1,680,000$ investment financed with a 20 -year municipal bond at $5.05 \%$ can be paid back in 15 years based on the energy savings and the above assumptions. Figure 17 shows the advanced payment schedule of the 20 -year bond.

A sensitivity analysis shown in Figure 18 was performed to identify the parameters that have the most significant effect on the economics. It can be seen that the availability of the plant is the 


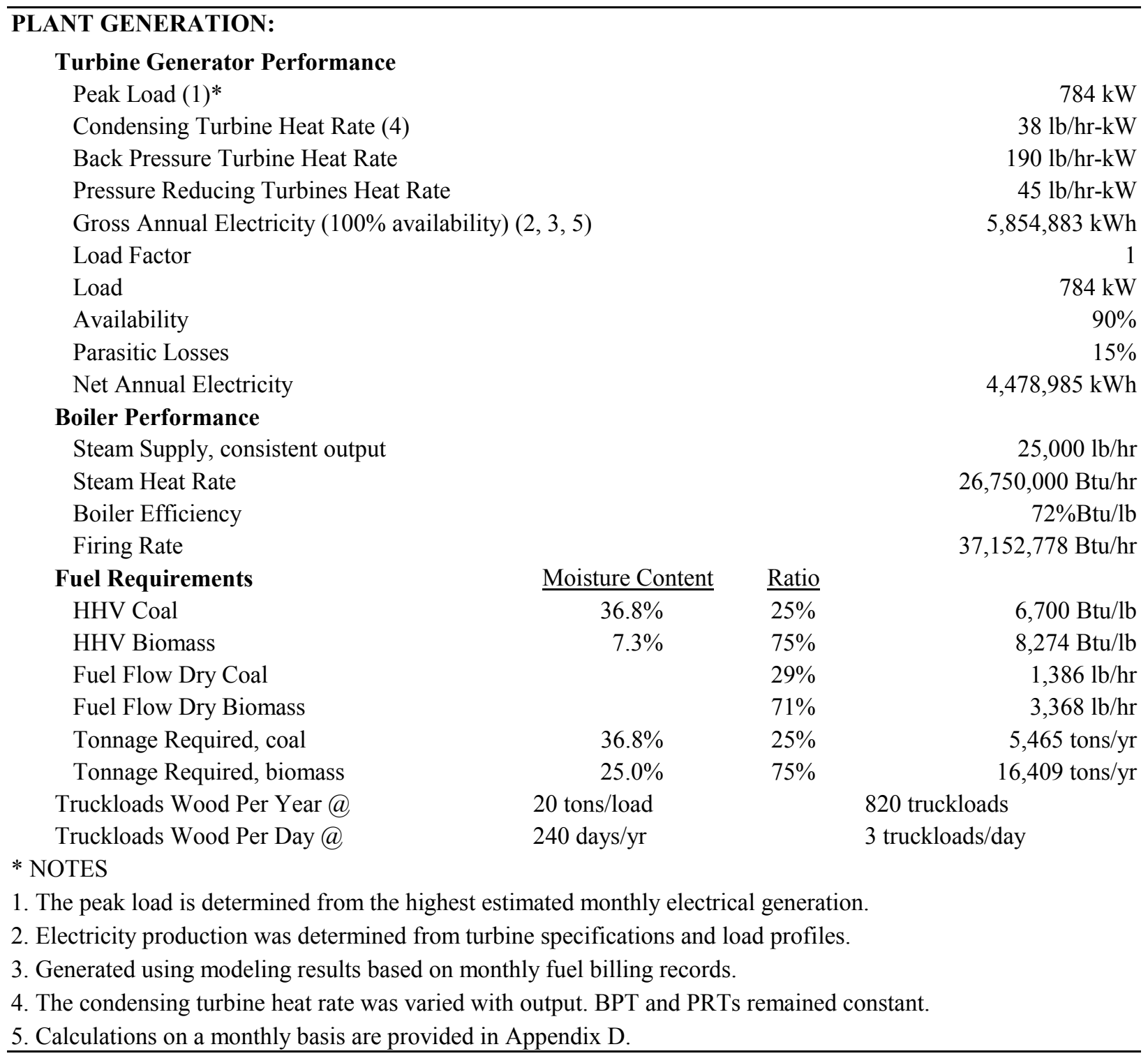

Figure 15. Base case scenario calculations.

most significant factor and plays an important role once the project is up and running. Next in order of significance is coal price, followed by blend ratio of biomass and electricity price. Although all factors have some effect on economics, it can be concluded that equipment maintenance and volatile gas prices will have little impact. A final conclusion drawn from the sensitivity analysis is that in no case can adjustment of a single factor result in paybacks of 5 years or less. Return on investment will most likely be limited to $15 \%$ even in the most attractive set of scenarios.

Some alternative economic cases were calculated to determine relative return on investment or payback. A best case scenario was developed by adjusting the most significant factors from the sensitivity analysis. Availability was adjusted to $92 \%$, cofiring rate to $90 \%$, capital investment at $\$ 1,550,000$, and the cost of coal at $\$ 22.00$ per ton. The results show the investment could be paid 
Natural Gas (1)
Interruptible gas consumption

Firm gas consumption

Coal
Present consula gas

Electricity (2)

Purchase price from utility
Present consumption

Subtotal energy
Operation and Mainte

Operation and Maintenance Costs

Labor current staff (4)

Ash disposal, $\$ 32$ thon
Repairs, ash gates

Repairs, misc.

Chemicals, \$0.10/MMBtu

Subtotal O\&M
Subtotal current cossts

A Subtotal current Cost
COST REDUCTIONS
Interrutible gas consumpition

Electrical Generation (5)

Cogen. system generation
Net suppilied power

$\%$ of present consumption

B Subtota

Additional labor (4)
Coal Purchase (delivered)
PAd

Coal Purchase (delivered)
Future consumption total

Additional
Ash disposal \$32t ton

Chemicals, \$0.10/MMBtu additional
Feed System Maintenance (7)

$\begin{array}{ll}\text { C } & \text { Subtotal } \\ \text { D } & \text { Savings before financing }\end{array}$

DeBT SERVIICE (8):
Project Cos

Project Cost
Downpayment

Downpayment
Amount Financed
Rate

Rate
Term

\begin{tabular}{ll} 
E & Annual Payment \\
\hline Boilerhouse Operational Costs (9)
\end{tabular}

5.18 per DKT
11,728 DKT

6.79 per DKT
6.243 DKT

19.42 per ton
2,938 tons
39,369 MMBt

0.0500 per kWh
$5,365,800 \mathrm{kWh}$

${ }_{165}^{4}$ people

$\frac{\text { Fuel Consumption }}{55,323}$ MMBtu

5.18 per DKT
$11,728 \mathrm{DKT}$

$4,478,985 \mathrm{kWh}$
$886,815 \mathrm{kWh}$

$83 \%$

2.5 people
19.42 per ton

5,465 tons

2,527 tons
306 tons

$\frac{\text { Additional Fuel Consumption }}{33,859 \text { MMBtu }}$

$\$ 1,680,000$

$\$ 1,680,000$
$0 \%$
$\$ 1,680,000$
$505 \%$

$5.05 \%$
20 years 20 years
$\mathrm{A}-\mathrm{B}+\mathrm{C}+\mathrm{E}$
$(\$ 135,380)$

\begin{tabular}{|c|c|c|c|c|c|c|c|c|c|c|c|c|c|c|c|c|c|c|}
\hline 2003 & 2004 & 2005 & 2006 & 2007 & 2008 & 2009 & 2010 & 2011 & 2012 & 2013 & 2014 & 2015 & 2016 & 2017 & 2018 & 2019 & 2020 & 2021 \\
\hline 1 & 2 & 3 & 4 & 5 & 6 & 7 & 8 & 9 & 10 & 11 & 12 & 13 & 14 & 15 & 16 & 17 & 18 & 19 \\
\hline
\end{tabular}

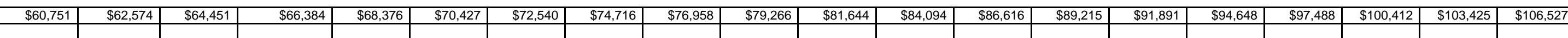

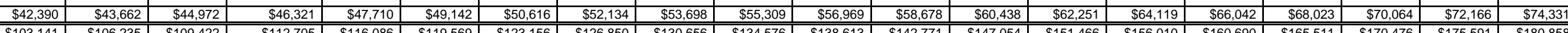

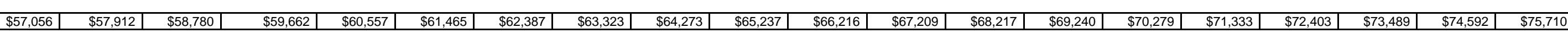

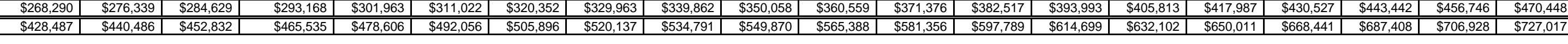

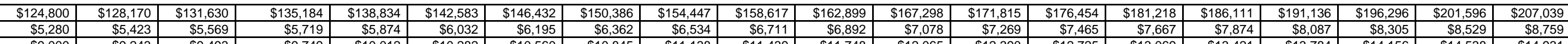

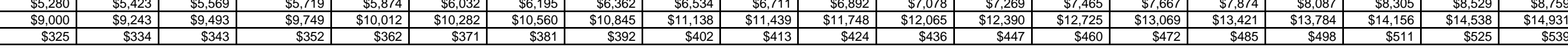

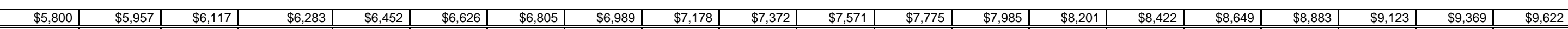

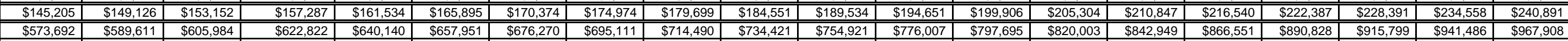

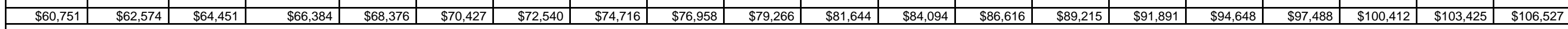

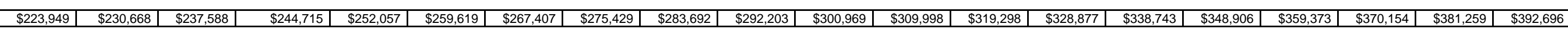

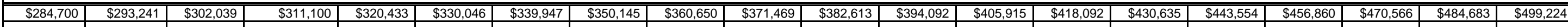

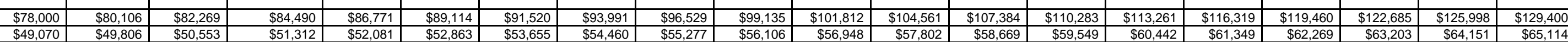

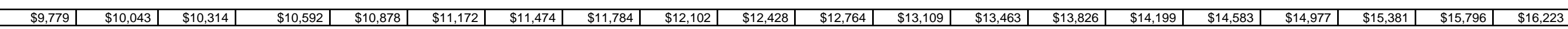

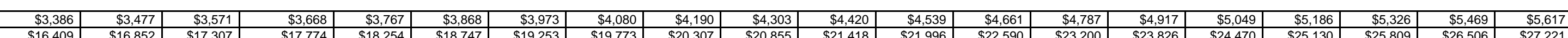

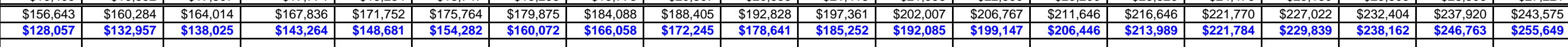

Savings

1. Fuel costs based on actual usage for facility.

2. Electricity rate includes monthly demand charge. Increases at $3 \%$ per year

3. Maintenance includes labor and materi
4. Labor cost increase is $2.7 \%$ per year.

5. Electricity charge includes monthly standby charge.

7. Maintenance is based on costs provided by CBI, $2.7 \%$ escallation is provided.

8. Debt Service is tor capital costs.
9. Net Cash Flow = Total tuel Cost Savings - O\&M Costs - Finance Costs

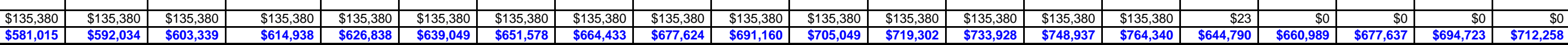

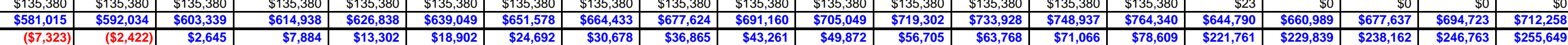




\begin{tabular}{|c|c|c|c|c|c|c|c|}
\hline \multicolumn{8}{|c|}{ Payment Schedule Using Advanced Payments from Energy Savings } \\
\hline \multicolumn{2}{|l|}{ Key Figures } & \multicolumn{3}{|c|}{ Inputs } & \multicolumn{3}{|c|}{ Calculated Numbers } \\
\hline Annual Loan Payment & $\$ 135,380$ & \multicolumn{2}{|c|}{ Loan Principal Amount } & $\$ 1,680,000$ & \multicolumn{2}{|c|}{ Effective Annual Interest } & 5.05 \\
\hline Payment per Year & $\$ 135,380$ & \multicolumn{2}{|c|}{ Annual Interest Rate, $\%$} & 5.05 & \multicolumn{2}{|c|}{ Effective Period Interest } & 5.05 \\
\hline Payment Amount & $\$ 135,380$ & \multicolumn{2}{|l|}{ Loan Period } & & \multicolumn{2}{|l|}{$0(1+\mathrm{I})^{\wedge} \mathrm{N}$} & 2.67868185 \\
\hline Interest in First Year & & \multicolumn{2}{|c|}{ \# of Pay Periods/yr } & & \multicolumn{2}{|c|}{$1 \mathrm{~A} / \mathrm{P}$ Factor } & 0.08058313 \\
\hline Total Interest & & \multicolumn{2}{|c|}{ Compounding Freq. } & & \multicolumn{2}{|c|}{1} & \\
\hline Total Payments & & \multicolumn{2}{|c|}{20 Starting Year of Loan } & & & & 135379.654 \\
\hline \multicolumn{2}{|l|}{ Total Amount Paid $(\mathrm{I}+\mathrm{P}+\mathrm{F})$} & \multicolumn{3}{|c|}{ Starting Month of Loan } & & & \\
\hline $\begin{array}{l}\text { Payment } \\
\text { Number }\end{array}$ & $\begin{array}{c}\text { Begin } \\
\text { Balance }\end{array}$ & Payments & Principal & Interest & $\begin{array}{c}\text { Cumulative } \\
\text { Principal }\end{array}$ & $\begin{array}{l}\text { Cumulative } \\
\text { Interest }\end{array}$ & $\begin{array}{l}\text { Ending } \\
\text { Balance }\end{array}$ \\
\hline 1 & $\$ 1,680,000$ & $\$ 128,057$ & $\$ 43,217$ & $\$ 84,840$ & $\$ 43,217$ & $\$ 84,840$ & $\$ 1,636,783$ \\
\hline 2 & $\$ 1,636,783$ & $\$ 132,957$ & $\$ 50,300$ & $\$ 82,658$ & $\$ 93,517$ & $\$ 167,498$ & $\$ 1,586,483$ \\
\hline 3 & $\$ 1,586,483$ & $\$ 138,025$ & $\$ 57,907$ & $\$ 80,117$ & $\$ 151,424$ & $\$ 247,615$ & $\$ 1,528,576$ \\
\hline 4 & $\$ 1,528,576$ & $\$ 143,264$ & $\$ 66,071$ & $\$ 77,193$ & $\$ 217,495$ & $\$ 324,808$ & $\$ 1,462,505$ \\
\hline 5 & $\$ 1,462,505$ & $\$ 148,681$ & $\$ 74,825$ & $\$ 73,857$ & $\$ 292,319$ & $\$ 398,665$ & $\$ 1,387,681$ \\
\hline 6 & $\$ 1,387,681$ & $\$ 154,282$ & $\$ 84,204$ & $\$ 70,078$ & $\$ 376,523$ & $\$ 468,742$ & $\$ 1,303,477$ \\
\hline 7 & $\$ 1,303,477$ & $\$ 160,072$ & $\$ 94,246$ & $\$ 65,826$ & $\$ 470,770$ & $\$ 534,568$ & $\$ 1,209,230$ \\
\hline 8 & $\$ 1,209,230$ & $\$ 166,058$ & $\$ 104,991$ & $\$ 61,066$ & $\$ 575,761$ & $\$ 595,634$ & $\$ 1,104,239$ \\
\hline 9 & $\$ 1,104,239$ & $\$ 172,245$ & $\$ 116,481$ & $\$ 55,764$ & $\$ 692,242$ & $\$ 651,398$ & $\$ 987,758$ \\
\hline 10 & $\$ 987,758$ & $\$ 178,641$ & $\$ 128,759$ & $\$ 49,882$ & $\$ 821,001$ & $\$ 701,280$ & $\$ 858,999$ \\
\hline 11 & $\$ 858,999$ & $\$ 185,252$ & $\$ 141,873$ & $\$ 43,379$ & $\$ 962,874$ & $\$ 744,659$ & $\$ 717,126$ \\
\hline 12 & $\$ 717,126$ & $\$ 192,085$ & $\$ 155,870$ & $\$ 36,215$ & $\$ 1,118,744$ & $\$ 780,874$ & $\$ 561,256$ \\
\hline 13 & $\$ 561,256$ & $\$ 199,147$ & $\$ 170,804$ & $\$ 28,343$ & $\$ 1,289,548$ & $\$ 809,218$ & $\$ 390,452$ \\
\hline 14 & $\$ 390,452$ & $\$ 206,446$ & $\$ 186,728$ & $\$ 19,718$ & $\$ 1,476,276$ & $\$ 828,936$ & $\$ 203,724$ \\
\hline 15 & $\$ 203,724$ & $\$ 213,989$ & $\$ 203,701$ & $\$ 10,288$ & $\$ 1,679,977$ & $\$ 839,224$ & $\$ 23$ \\
\hline 16 & $\$ 23$ & $\$ 24$ & $\$ 23$ & $\$ 1$ & $\$ 1,680,000$ & $\$ 839,225$ & $\$ 0$ \\
\hline
\end{tabular}

Figure 17. Loan payments from energy savings.

back in 9 years. A second case was run to determine how much the capital investment would have to be reduced in order to have an attractive return if $0 \%$ escalation was assumed for all energy-related costs. In this case, all assumptions are the same as the base case except for escalation and capital investment. It is assumed that the dryer and hydrograte could be eliminated from the fuel-handling system. The total capital is then reduced to $\$ 1,069,834$. The resulting payback period from the energy savings is 15 years and provides a positive scenario given a more realistic energy escalation assumption ( $0 \%$ vs. $3 \%)$.

\section{RESULTS AND DISCUSSION}

The results of this feasibility study were presented to the NDSP and the DCS. The NDSP is very pleased with the results of the study and wants to pursue implementation. Moving forward with this project will benefit the NDSP from several aspects: 


\begin{tabular}{|c|c|c|c|c|c|c|c|c|}
\hline \multicolumn{4}{|l|}{ Sensitivity Analysis } & \multicolumn{2}{|c|}{ Annualized Savings } & \multicolumn{2}{|c|}{$\begin{array}{c}\text { Advanced } \\
\text { Payback on } \\
\text { Debt (years) }\end{array}$} & \multirow{3}{*}{$\begin{array}{c}\text { Sensitivity } \\
\% \text { effect } / \\
\% \text { change }\end{array}$} \\
\hline & & & & Base & $\$ 82,877$ & Base & 15 & \\
\hline Variable & Base & High & Low & High & Low & High & Low & \\
\hline Coal Price & $\$ 19.42$ & $\$ 20.00$ & $\$ 15.00$ & $\$ 65,811$ & $\$ 96,395$ & 16 & 14 & 6.89 \\
\hline Gas Price & $\$ 5.18$ & $\$ 8.00$ & $\$ 3.50$ & $\$ 119,588$ & $\$ 61,006$ & 13 & 16 & 0.81 \\
\hline Electricity Price & $\$ 0.05$ & $\$ 0.07$ & $\$ 0.04$ & $\$ 205,627$ & $\$ 21,502$ & 10 & 19 & 3.7 \\
\hline Availability@75-25 cofire & $92 \%$ & $95 \%$ & $70 \%$ & $\$ 148,000$ & $\$ 44,670$ & 14 & 17 & 24.1 \\
\hline Wood Tonnage & 16773 & 17320 & 12762 & & & & & \\
\hline \%Wood Cofired@92\% availability & $75 \%$ & $100 \%$ & $65 \%$ & $\$ 200,892$ & $\$ 35,671$ & 10 & 18 & 4.27 \\
\hline Wood Tonnage & 16773 & 22364 & 14537 & & & & & \\
\hline Feed System O\&M, \$/ton & $\$ 1.00$ & $\$ 3.00$ & $\$ 0.50$ & $\$ 39,246$ & $\$ 93,785$ & 18 & 14 & 0.26 \\
\hline Capital Investment & $\$ 1,680,000$ & $\$ 1,800,000$ & $\$ 1,400,000$ & $\$ 74,586$ & $\$ 102,223$ & 15 & 13 & 1.4 \\
\hline Additional Labor, no. of people & 3 & 4 & 0 & $\$ 22,008$ & $\$ 184,325$ & 19 & 10 & 1.22 \\
\hline
\end{tabular}

Figure 18. Sensitivity analysis.

1. Energy cost savings can be achieved and used to pay back a typical municipal bond, while obtaining upgrades to NDSP's energy system.

2. Skilled new hires will have employment, and work will be available for prisoner personnel.

3. The long-term energy costs for the NDSP will decrease.

4. The public image of the Department of Corrections will improve by enabling its agency to apply public funds to an environmentally and economically beneficial project that affects the general public directly and is not limited to inmates.

The specific results from the various tasks are summarized below.

\section{Task 1 - Local Biomass Resource Assessment}

1. Municipal wood residue is the most viable biomass resource in terms of quantity, cost, quality, reliability, and availability. It was determined that 30,000 tons/yr could be obtained within 100 mile radius of Bismarck, which is twice the amount required for the project. Also, at least half of the required wood resource $(8,000$ tons/yr) was confirmed to be available from local haulers in the Bismarck and Mandan area. Delivered cost is expected to be $\$ 0.00$ per ton, since haulers must currently pay $\$ 10.00$ per ton to dispose of wood residues at the local landfill.

\section{Task 2 - Fuel-Handling Issues}

2. Wood residues will require adequate bulk storage, handling, sizing, segregation, and potential drying. All of these issues have been addressed with a robust mechanical fuel receiving and feed system design optimized to reduce cost. 


\section{Task 3 - Fireside Issues}

3. Fuel characterization supports the notion that wood residue may be favored over lignite coal because of its lower moisture, lower sulfur, and lower ash content. However, ash constituents that contribute to tube fouling problems exist in higher concentrations than in coal ash, namely, calcium, potassium, and phosphorus.

4. Modeling of the fouling, slagging, and opacity potentials for lignite coal and wood blends resulted in a low index value, indicating favorable performance. In general, the greater the percentage of biomass fired with lignite, the better the results. No optimum blend ratio was determined, although blend ratios of greater than $85 \%$ could be problematic from an opacity standpoint.

5. DTF tests were completed to provide data with respect to utilities on the cofiring of wood and lignite coal. Tests run at a 50\% blend ratio indicated that no decrease in fireside performance will result from cofiring wood residue. Samples collected from tree service companies show better results than wood collected from hardwood sawdust. Tree wood samples produced less sintered deposits with half the crushing strength of lignite coal deposits. Also, the particle size of the fly ash from the biomass blends tended to be larger, which would result in better capture efficiency. The average reduction in $\mathrm{SO}_{\mathrm{x}}$ and $\mathrm{NO}_{\mathrm{x}}$ emissions was $46 \%$ and $33 \%$, respectively.

6. Cofiring tests were conducted in a bench-scale grate-fired furnace to obtain information regarding clinker formation relative to stoker-fired systems. A blend of $75 \%$ wood fired with lignite coal was compared to baseline lignite. At this time, results are not available from the advanced analysis; however, we visually observed that clinker formation decreased with the addition of wood fuel.

\section{Task 4 - Environmental Issues}

7. An environmental emission study determined that the firing of biomass at the NDSP will not adversely affect the economics from an air quality permitting standpoint. Also, no other permitting issues will limit application of the technology, such as transfer station permitting, solid waste considerations, and water quality issues.

\section{Task 5 - Energy Production Assessment}

8. The energy production assessment revealed that offsetting electrical costs will be the most beneficial economic aspect of the project. The best method to achieve this goal is to apply used condensing and back-pressure steam turbines. This will allow for some redundancy since both turbines can be operated in either mode and will optimize electrical production output.

\section{Task 6 - Engineering Economic Analysis}

9. The economics show a 15- to 20-year return on investment for the NDSP facility depending on various factors. An investment of $\$ 1,680,000$ would be required for the complete project. Depending on the final decision of NDSP on proper escalation factors, this investment may have 
to be reduced to $\$ 1,250,000$ and would eliminate a nonessential fuel dryer or result in the purchase of used versus new fuel-handling equipment. The 20-year return on investment is acceptable to the Department of Corrections, which is a publicly funded agency that values the benefit to the community that results from utilizing a resource that would otherwise be buried in the landfill.

\section{CONCLUSION}

This study presents a clear case that cofiring biomass with lignite coal can be beneficial to both small stoker-fired institutions and utility-scale installations. The primary hurdle for utility-scale systems is more of an economic and resource-based issue. It can be difficult to locate sufficient quantities of biomass at costs that economically benefit large utilities. This is not the case with small stoker-fired institutions, as in this study we identified a resource available at $\$ 0.00 /$ ton and in sufficient quantity to supply $100 \%$ of the capacity. The results from this study indicate that cofiring wood residues will produce favorable fireside performance in boilers and the greater the amount cofired, the better the results. Care must be taken in the mechanical feed system design to address the sizing and handling issues relative to specific biomass fuels. The NDSP, through the results of this study, has the potential to move forward with a cofiring application that can achieve the following for the local community and the facility:

- Reduced sulfur and $\mathrm{NO}_{\mathrm{x}}$ emissions and zero net gain of carbon dioxide.

- Reduction of landfill burden and associated taxpayer costs.

- Alleviation of tipping fees for disposal from local businesses.

- Additional jobs at NDSP and potentially other businesses benefiting from lower disposal costs.

- Reduction in energy costs, which will benefit taxpayers in the long term.

- Increased energy reliability and security.

- No significant change to the NDSP air quality permit.

- 15- to 20-year return on investment.

Support of feasibility studies for cofiring biomass on behalf of DOE should be continued. In many cases, the infrastructure and market conditions are available to take advantage of cofiring biomass; however, various factors inhibit the progress for biomass utilization. DOE's support helps to overcome barriers resulting in viable projects that would not move forward otherwise. This project is a case in point, and the following barriers addressed by this study are outlined as follows: 
1. District energy systems, approximately 5800 of them throughout the United States, provide an appropriately sized infrastructure for utilizing biomass. The primary concern for facility managers is usually a consistent supply of energy. Cost is secondary. State-funded institutions provide very limited incentives to lower energy costs through investigation of alternative fuels or fuel diversification. This forces facility managers to focus budget justification efforts on maintenance upgrades as opposed to exploring nontraditional solutions to lower costs. DOE-funded studies can help facility managers see specific cases that could reduce costs by cofiring biomass.

2. Biomass is site-specific, case-specific, and nontraditional. These attributes create greater difficulty evaluating biomass relative to fossil fuels. Typical energy-related engineering firms realize the technical and market difficulties of biomass and tend to focus on more reliable, profitable fossil energy solutions. The result is a low availability of off-the-shelf equipment and knowledge of how to take advantage of biomass fuels. Compared to fossil energy, significant work must be done to verify biomass resource availability prior to implementation, since biomass may come from a variety of sources. DOE-funded studies help to alleviate the effort of resource evaluation by employing knowledgeable research facilities. Resulting case studies help to demonstrate how to seek available resources and provide detailed information on equipment that is unique for biomass applications.

3. Potential biomass fuel suppliers are not significant drivers of the market and do not have the benefit of the infrastructure of fossil fuels. Natural gas and coal are brokered commodities made available from the supplier and marketed to a target audience. The industries have been well developed over time and operate at peak efficiencies to provide competitive costs. Biomass, a relatively immature industry, lacks procurement efficiency. Many potential fuel suppliers pay to dispose of material or have found some low-valueadded markets for residues. Small businesses that generate wood residues do not have the resources to collaborate and convince energy users to utilize their waste. DOE's support of this study helped to link the generators of waste material to an energy consumer.

\section{REFERENCES}

1. Schmidt, D.D.; Pinapati, V. Opportunities for Small Biomass Power Systems; Final Technical Report for U.S. Department of Energy Contract No. DE-FG02-99EE35128; EERC Publication 2000-EERC-11-01; Energy \& Environmental Research Center: Grand Forks, ND, Nov 2000.

2. Vogel, K.P.; Masters, R.A. Developing Switchgrass into a Biomass Fuel Crop for the Midwestern USA. In Proceedings of BioEnergy '98: Expanding Bioenergy Partnerships Conference; Madison, WI, Oct 4-8, 1998.

3. Glassner, D.A.; Hettenhaus, J.R.; Schechinger, T.M.; Corn Stover Collection Project. In Proceedings of BioEnergy '98: Expanding Bioenergy Partnerships Conference; Madison, WI, Oct 4-8, 1998. 
4. http://www.nass.usda.gov/nd/janrank.htm (accessed Oct 2001).

5. Zygarlicke, C.J.; McCollor, D.P.; Eylands, K.E.; Hetland, M.D.; Musich, M.A.; Crocker, C.R.; Dahl, J.; Laducer, S. Task 3.4 - Impacts of Cofiring Biomass with Fossil Fuels; Final Report for U.S. Department of Energy Contract No. DE-FC26-98FT40320 Task 3.4; EERC Publication 2001-EERC-08-03; Energy \& Environmental Research Center: Grand Forks, ND, Aug 2001.

6. Fuller, S.K.; Boyles A.S. Energy Price Indices and Discount Factors for Life-Cycle Cost Analysis - April 2001. NISTIR 85-3273-16 Rev. 4-01, Annual Supplement to NIST Handbook 135 and NBS Special Publication 709, U.S. Department of Commerce Technology Administration National Institute of Standards and Technology, Prepared for U.S. DOE Federal Energy Management Program.

7. http://www.eia.doe.gov/oiaf/aeo/aeotab_8.htm (accessed Oct 2001). 
APPENDIX A

\section{BIOMASS RESOURCES}




\section{BIOMASS RESOURCES}

A-1. Grain Elevators/Contacts 


\section{Ag Processors}

\section{Source}

Mandan Farmers Elevator

Farmers Union

South Central

Falkirk Farmers Elevato

Raleigh Grain Company

Steele Farmers

Ada Supply

Tuttle Farmers

Dakota Grain

Benson-Quinn

Coop Elevator

\section{$\underline{\text { Contact }}$}

Jerry Janz

\section{Phone \#}

(701) 663-3710

\section{$\$ 3$}

\section{Duane Rudland}

(701) 734-6780

$\$ 25$

Bill Schauer

(701) 387-4506

$\$ 20$

Jeremy Rademacher, (701) 462-8572 \$10-\$20

Assistant Manager

Mike Himmelspach

(701) $597-3571$

Clayton Martin

(701) $475-2334$

$\$ 15$

(701) $475-2128$

\section{Ed Bickle}

Jim Meyer

Dean Ash, Laborer

(701) 584-2660

$\$ 20$

$\$ 35$

(701) $442-3204$
Brian Larson
(701) 363-2529
$\$ 25$
Reliability

Availability

Mostly wheat screenings, Most during harvest, Currently more than
vattle $\begin{array}{lll}\text { very seldom barley or oats least in December and } 50 \% \text { feed, remainder mostly } \\ \text { except in spring } & \text { January } & \end{array}$ for hogs

Mix of wheat, barley, oats Most during harvest Sold to local cattle armers

\section{Screenings}

Most during harvest

Sold for feed
520

Wheat screenings

200

$70 \%$ wheat screening
remainder barley

during harvest

least right before

harvest

least in January

Wheat screenings, pigeon Most during feed

grass

cleaning, least in

January, February

Removal service; they don't

actually handle screenings

$\begin{array}{ll}\text { Wheat screenings } & \text { Varies } \\ \text { Wheat screenings } & \text { Varies }\end{array}$

100 tons off ground; $13 \%$ picked up off ground, Varies 700-800 tons sold remainder wheat

screenings

400
$80 \%$ wheat, $10 \%$ durham, Most in harvest, least in Mostly sold to local $10 \%$ other winter month cattle farmers, some to nearby turkey farmers with corn and oats; some to turkeys in Larimore

Cow and calf feed Sold for cattle feed

N/A 


\begin{tabular}{|c|c|c|c|c|c|c|c|}
\hline Farmers Elevator & Jeff & (701) 748-2355 & $\$ 25$ & 700 & $\begin{array}{l}\text { Mostly wheat screenings, } \\
\text { some durham }\end{array}$ & Varies & $\mathrm{N} / \mathrm{A}$ \\
\hline Equity Elevator & $\begin{array}{l}\text { Jeremy, Assistant } \\
\text { Manager }\end{array}$ & (701) 448-2461 & $\$ 20$ & 300 & $\mathrm{~N} / \mathrm{A}$ & $\mathrm{N} / \mathrm{A}$ & $\mathrm{N} / \mathrm{A}$ \\
\hline Hepper Grain, Inc. & & (701) 422-3351 & & & $\begin{array}{l}\text { Phone number not in } \\
\text { service }\end{array}$ & & \\
\hline Tappen Grain & Melissa Johnson & (701) 327-4254 & $\$ 20-\$ 25$ & 30 & $\begin{array}{l}\text { Mostly wheat and flax, } \\
\text { some oats }\end{array}$ & $\begin{array}{l}\text { Most in harvest, least in } \\
\text { late winter, when it's all } \\
\text { been sold }\end{array}$ & $\begin{array}{l}\text { Sold to local livestock } \\
\text { farmers }\end{array}$ \\
\hline $\begin{array}{l}\text { Goodrich Farmers Co-Op } \\
\text { Association }\end{array}$ & Mike & (701) 884-2707 & $\$ 20$ & 350 & Wheat screenings & $\begin{array}{l}\text { Most in harvest, least in } \\
\text { late winter, when it's all } \\
\text { been sold }\end{array}$ & $\begin{array}{l}\text { Sold locally as cattle } \\
\text { feed }\end{array}$ \\
\hline Beulah Farmers Union Elevator & & (701) 873-4413 & & & No contact & & \\
\hline Southwest Grain Co-Operative & Kenny & (701) 584-2152 & $\$ 25$ & 100 & Wheat screenings & $\mathrm{N} / \mathrm{A}$ & $\mathrm{N} / \mathrm{A}$ \\
\hline Hebron Farmers Elevator & Bonnie, Bookkeeper & (701) 878-4462 & $\$ 30$ & $\mathrm{~N} / \mathrm{A}$ & Wheat screenings & & \\
\hline Hurdsfield Grain Inc. & Heidi, Bookkeeper & (701) 962-3344 & $\$ 25$ & 117 & Wheat screenings & & \\
\hline Modern Grain Inc. & Tim Meuchel & (701) 878-4525 & $\$ 30$ & 500 & Wheat screenings & & \\
\hline New Leipzig Grain Company & Jeff, Secondman & (701) 584-3830 & $\$ 25-\$ 30$ & 75 & Wheat screenings & & \\
\hline $\begin{array}{l}\text { Garrison Farmers Union } \\
\text { Elevator Company }\end{array}$ & $\begin{array}{l}\text { Clint, Assistant } \\
\text { Manager }\end{array}$ & (701) 463-2251 & $\$ 20$ & 200 & Wheat screenings & & \\
\hline Bentley Equity Exchange & Lyle & (701) 824-2600 & $\$ 20$ & $\mathrm{~N} / \mathrm{A}$ & Wheat screenings & & \\
\hline ADM & $\begin{array}{l}\text { Tim Bourdeau, Plant } \\
\text { Engineer }\end{array}$ & (701) 338-2491 & & & $\begin{array}{l}\text { Processor; only deal with } \\
\text { screened material and } \\
\text { recycling, no waste }\end{array}$ & & $\begin{array}{l}\text { ADM plant in Enderlin, } \\
\mathrm{ND} \text {, that deals with } \\
\text { waste, but too far away } \\
\text { for our purposes }\end{array}$ \\
\hline
\end{tabular}


A-2. Municipal Woody Residues/Contacts 


\section{Municipal Woody Residue}

\begin{tabular}{|c|c|c|c|c|c|c|c|}
\hline Source & Contact & Phone \# & Price & Quantity & Quality & Reliability & Availability \\
\hline B \& V Tree \& Yard Service & Vira Doll, Manager & (701) 255-1035 & Free & No estimate & $\begin{array}{l}\text { Anything from tree, } \\
\text { including branches, } \\
\text { leaves, etc. }\end{array}$ & $\begin{array}{l}\text { VERY INTERESTED; } \\
\text { willing to give away } \\
\text { everything they have }\end{array}$ & $\begin{array}{l}\text { Can have it all; summer } \\
\text { only }\end{array}$ \\
\hline $\begin{array}{l}\text { Belohlavek Landscaping \& } \\
\text { Tree }\end{array}$ & $\begin{array}{l}\text { Jim Belohlavek, } \\
\text { Owner }\end{array}$ & (701) 663-5124 & Free & $\begin{array}{l}\text { More than } 500 \text { tons } \\
\text { every summer }\end{array}$ & All branches & $\begin{array}{l}\text { Willing to give away } \\
\text { everything they have }\end{array}$ & $\begin{array}{l}\text { Can have it all; summer } \\
\text { only }\end{array}$ \\
\hline $\begin{array}{l}\text { Dakota Tree Movers \& } \\
\text { Nursery }\end{array}$ & Rosemary W., Owner & (701) 223-5223 & $\mathrm{N} / \mathrm{A}$ & None & $\mathrm{N} / \mathrm{A}$ & $\mathrm{N} / \mathrm{A}$ & $\mathrm{N} / \mathrm{A}$ \\
\hline Dan's Repair \& Tree Service & Dan, Owner & (701) 222-2214 & $\mathrm{N} / \mathrm{A}$ & None & $\mathrm{N} / \mathrm{A}$ & $\mathrm{N} / \mathrm{A}$ & $\mathrm{N} / \mathrm{A}$ \\
\hline Ellingson & $\mathrm{N} / \mathrm{A}$ & Unlisted & $\mathrm{N} / \mathrm{A}$ & $\mathrm{N} / \mathrm{A}$ & $\mathrm{N} / \mathrm{A}$ & $\mathrm{N} / \mathrm{A}$ & $\mathrm{N} / \mathrm{A}$ \\
\hline Outdoor Services & Kim, Secretary & (701) 222-3889 & $N / A$ & None & $\mathrm{N} / \mathrm{A}$ & $\mathrm{N} / \mathrm{A}$ & $\mathrm{N} / \mathrm{A}$ \\
\hline Rohrich Tree Service & $\mathrm{N} / \mathrm{A}$ & Disconnected & $\mathrm{N} / \mathrm{A}$ & $\mathrm{N} / \mathrm{A}$ & $\mathrm{N} / \mathrm{A}$ & $\mathrm{N} / \mathrm{A}$ & $\mathrm{N} / \mathrm{A}$ \\
\hline S\&B Landscaping \& Nursery & $\begin{array}{l}\text { Steve Becker, } \\
\text { Manager }\end{array}$ & (701) 224-0100 & Free & 2000 pallets/yr & $\begin{array}{l}\text { Ground waste and } \\
\text { pallets }\end{array}$ & $\begin{array}{l}\text { VERY INTERESTED; } \\
\text { say it would be best to } \\
\text { take pallets once a } \\
\text { year rather than make } \\
\text { frequent visits }\end{array}$ & $\begin{array}{l}\text { Can have it all; once a } \\
\text { year - will even grind it } \\
\text { for us }{ }^{* *} \text { MANAGER IS } \\
\text { ON CITY BOARD** }\end{array}$ \\
\hline Seibel's Tree Service & Justin Seibel, Owner & (701) 255-1680 & $\mathrm{N} / \mathrm{A}$ & None & $\mathrm{N} / \mathrm{A}$ & $\mathrm{N} / \mathrm{A}$ & $\mathrm{N} / \mathrm{A}$ \\
\hline Bismarck Landfill & Keith Hunke & (701) 222-6431 & Free & 7900 & $\begin{array}{l}38 \% \text { clean, } 49 \% \\
\text { C\&D wood, } 13 \% \\
\text { firewood }\end{array}$ & $\begin{array}{l}\text { More in summer less in } \\
\text { winter but fairly } \\
\text { consistent }\end{array}$ & $\begin{array}{l}\text { Would have to arrange } \\
\text { transportation or send } \\
\text { haulers to State } \\
\text { Penitentiary instead }\end{array}$ \\
\hline Mandan Landfill & Pete Snider & (701) 667-3240 & Free & 5000 & $\begin{array}{l}\text { Tree trimmings, did } \\
\text { not provide numbers } \\
\text { on C\&D debris }\end{array}$ & $\begin{array}{l}\text { More in summer less in } \\
\text { winter but fairly } \\
\text { consistent }\end{array}$ & $\begin{array}{l}\text { Would have to arrange } \\
\text { transportation or send } \\
\text { haulers to State } \\
\text { Penitentiary instead }\end{array}$ \\
\hline Garbage + & Darrell Lauer & (701) 223-5343 & Free & $120-180$ & $\begin{array}{l}\text { As high as } 50 \% \\
\text { paper, cardboard, } \\
\text { mostly sawdust. }\end{array}$ & Consistent year-round & $\begin{array}{l}\text { Available for drop-off via } \\
\text { roll-off container }\end{array}$ \\
\hline A1 Tree Service & Pat Bosch & $\begin{array}{l}\text { (701) } 258-8517 \\
(701) 221-4622\end{array}$ & Free & 700 & $\begin{array}{l}\text { Tree trimmings, } \\
\text { separates firewood } \\
\text { but doesn't have to }\end{array}$ & $\begin{array}{l}\text { Busy May-August, } \\
\text { slower in winter, but } \\
\text { does business year- } \\
\text { round }\end{array}$ & $100 \%$ \\
\hline
\end{tabular}




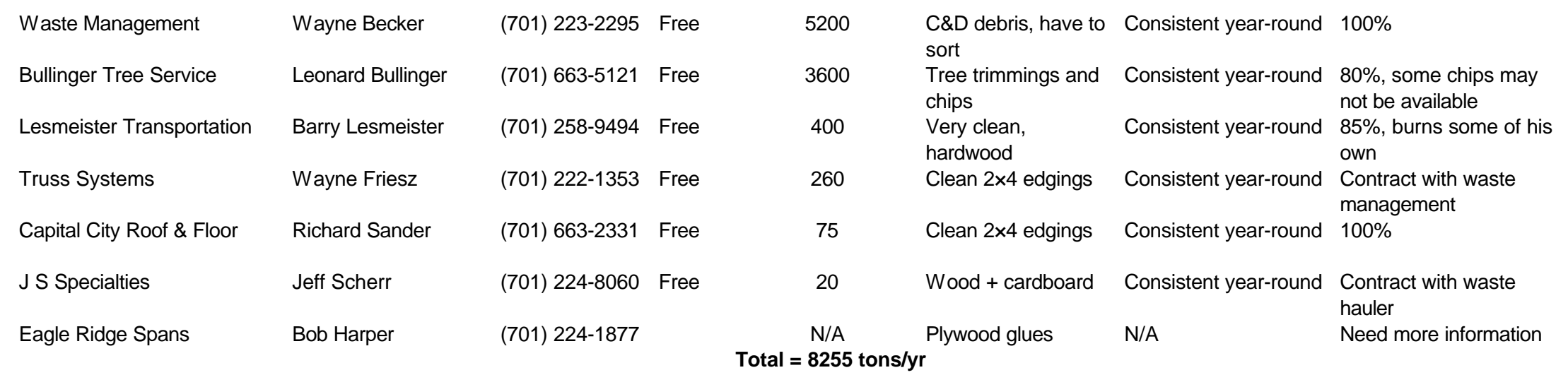


A-3. Theoretical Biomass Resource by County 


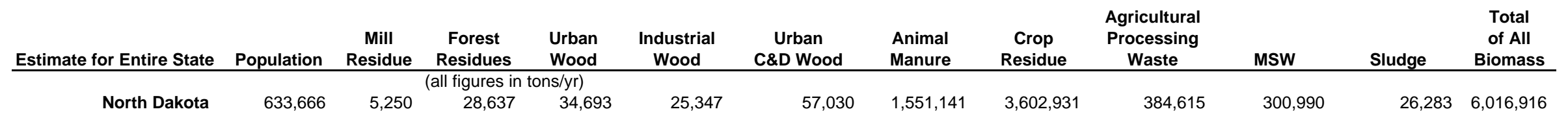

Biomass Resources (counties within 100-mile radius of Bismarck, ND)

\begin{tabular}{|c|c|c|c|c|c|c|c|c|c|c|c|c|}
\hline $\begin{array}{l}\text { North Dakota } \\
\text { County }\end{array}$ & Population & $\begin{array}{c}\text { Mill } \\
\text { Residue }\end{array}$ & $\begin{array}{c}\text { Forest } \\
\text { Residues }\end{array}$ & $\begin{array}{l}\text { Urban } \\
\text { Wood }\end{array}$ & $\begin{array}{c}\text { Industrial } \\
\text { Wood }\end{array}$ & $\begin{array}{l}\text { Urban } \\
\text { C\&D Wood }\end{array}$ & $\begin{array}{c}\text { Animal } \\
\text { Manure } \\
\end{array}$ & $\begin{array}{c}\text { Crop } \\
\text { Residue }\end{array}$ & $\begin{array}{c}\text { Agricultural } \\
\text { Processing } \\
\text { Waste } \\
\end{array}$ & MSW & Sludge & $\begin{array}{c}\text { Total } \\
\text { of All } \\
\text { Biomass }\end{array}$ \\
\hline 1 Adams & 2,644 & 0 & 0 & 159 & 106 & 238 & 25,578 & 31,243 & & 1,381 & 121 & 58,826 \\
\hline 2 Benson & 6,781 & 0 & 0 & 408 & 271 & 610 & 20,947 & 106,106 & & 3,543 & 309 & 132,195 \\
\hline 3 Burleigh & 67,371 & 0 & 0 & 4,057 & 2,695 & 6,063 & 49,375 & 58,011 & & 35,201 & 3074 & 158,477 \\
\hline 4 Dickey & 5,662 & 0 & 0 & 341 & 226 & 510 & 34,701 & 153,526 & & 2,958 & 258 & 192,521 \\
\hline 5 Dunn & 3,457 & 0 & 762 & 208 & 138 & 311 & 71,850 & 50,260 & & 1,806 & 158 & 125,494 \\
\hline 6 Eddy & 2,765 & 0 & 0 & 167 & 111 & 249 & 11,823 & 47,914 & & 1,445 & 126 & 61,834 \\
\hline 7 Emmons & 4,302 & 0 & 0 & 259 & 172 & 387 & 56,077 & 95,573 & & 2,248 & 196 & 154,913 \\
\hline 8 Foster & 3,787 & 0 & 0 & 228 & 151 & 341 & 13,000 & 68,425 & & 1,979 & 173 & 84,297 \\
\hline 9 Grant & 2,854 & 0 & 0 & 172 & 114 & 257 & 51,798 & 55,794 & & 1,491 & 130 & 109,756 \\
\hline 10 Hettinger & 2,839 & 0 & 0 & 171 & 114 & 256 & 20,221 & 65,145 & & 1,483 & 130 & 87,519 \\
\hline 11 Kidder & 2,798 & 0 & 0 & 169 & 112 & 252 & 54,669 & 38,855 & & 1,462 & 128 & 95,647 \\
\hline 12 LaMoure & 4,700 & 0 & 0 & 283 & 188 & 423 & 27,747 & 146,301 & & 2,456 & 214 & 177,613 \\
\hline 13 Logan & 2,268 & 0 & 0 & 137 & 91 & 204 & 37,353 & 48,627 & & 1,185 & 103 & 87,700 \\
\hline 14 McHenry & 5,962 & 0 & 100 & 359 & 238 & 537 & 60,601 & 67,537 & & 3,115 & 272 & 132,759 \\
\hline 15 McIntosh & 3,397 & 0 & 0 & 205 & 136 & 306 & 36,307 & 51,303 & & 1,775 & 155 & 90,186 \\
\hline 16 McLean & 9,603 & 0 & 0 & 578 & 384 & 864 & 35,907 & 121,767 & & 5,018 & 438 & 164,956 \\
\hline 17 Mercer & 9,210 & 0 & 0 & 555 & 368 & 829 & 25,582 & 35,319 & & 4,812 & 420 & 67,885 \\
\hline 18 Morton & 24,568 & 0 & 12.5 & 1,480 & 983 & 2,211 & 92,857 & 82,656 & & 12,837 & 1121 & 194,157 \\
\hline 19 Oliver & 2,158 & 0 & 0 & 130 & 86 & 194 & 35,784 & 33,368 & & 1,128 & 98 & 70,789 \\
\hline 20 Pierce & 4,594 & 0 & 0 & 277 & 184 & 413 & 21,112 & 66,969 & & 2,400 & 210 & 91,565 \\
\hline 21 Sheridan & 1,665 & 0 & 0 & 100 & 67 & 150 & 17,886 & 65,145 & & 870 & 76 & 84,293 \\
\hline 22 Sioux & 4,156 & 0 & 0 & 250 & 166 & 374 & 24,982 & 13,641 & & 2,171 & 190 & 41,774 \\
\hline 23 Stark & 22,490 & 0 & 1187 & 1,354 & 900 & 2,024 & 50,347 & 55,166 & & 11,751 & 1026 & 123,755 \\
\hline 24 Stutsman & 21,090 & 0 & 0 & 1,270 & 844 & 1,898 & 50,359 & 142,712 & & 11,019 & 962 & 209,064 \\
\hline 25 Ward & 58,360 & 0 & 2350 & 3,515 & 2,334 & 5,252 & 37,470 & 136,545 & & 30,493 & 2663 & 220,622 \\
\hline $\begin{array}{l}26 \text { Wells } \\
\text { South Dakota }\end{array}$ & 5,094 & 0 & 0 & 307 & 204 & 458 & $\begin{array}{c}16,859 \\
-\end{array}$ & 127,314 & & 2,662 & 232 & 148,036 \\
\hline 27 Campbell & 1,847 & 0 & 0 & 111 & 74 & 166 & 31,952 & 55,679 & & 965 & 84 & 89,031 \\
\hline 28 Corson & 4,104 & 0 & 0 & 247 & 164 & 369 & 52,119 & 41,412 & & 2,144 & 187 & 96,643 \\
\hline 29 McPherson & 2,693 & 0 & 0 & 162 & 108 & 242 & 63,293 & 43,753 & & 1,407 & 123 & 109,088 \\
\hline 30 Walworth & 5,614 & 0 & 0 & 338 & 225 & 505 & 31,473 & 74,632 & (estimated 6.5\%) & 2,933 & 256 & $\begin{array}{c}110,362 \\
-\end{array}$ \\
\hline 100 -mile radius total & 298,833 & - & 4,412 & 17,997 & 11,953 & 26,895 & $1,160,030$ & $2,180,697$ & 239,977 & 156,139 & 13,634 & $3,811,734$ \\
\hline
\end{tabular}


A-4. Crop Residue and Animal Manure by County 
Collectible Assumptions

\begin{tabular}{|c|c|c|c|c|c|c|c|c|c|}
\hline Crop & $\begin{array}{l}\text { Residue } \\
\text { Generation } \\
\text { Factor }\end{array}$ & $\begin{array}{l}\text { Residue } \\
\text { Collection } \\
\text { Factor }\end{array}$ & Livestock & $\begin{array}{l}\text { Tons/Dry } \\
\text { Manure/ } \\
\text { Animal/Year }\end{array}$ & $\begin{array}{l}\text { Percent } \\
\text { Collectible }\end{array}$ & $\begin{array}{l}\text { Tons/Dry } \\
\text { Manure/ } \\
\text { Animal/Year }\end{array}$ & Conversion & & Poultry \\
\hline Corn Grain & 1 & 0.55 & Animal/Year & & & & Corn Grain & 56 & 270,000 chickens statewide \\
\hline Barley & 1.5 & 0.55 & Cattle and calves & 0.73 & $100 \%$ & 0.73 & Barley & 48 & $1,800,000$ turkeys \\
\hline Oats & 1.4 & 0.5 & Milk cows/dairy cattle & 2.13 & $80 \%$ & 1.7 & Oats & 38 & \\
\hline Sorghum & 0.9 & 0.5 & Hogs and pigs & 0.27 & $100 \%$ & 0.27 & Sorghum & & \\
\hline Wheat & 0.9 & 0.25 & Chickens & 0.01644 & $100 \%$ & 0.01644 & Wheat & 60 & \\
\hline Peanuts & 1.25 & 0.3 & Sheep and lambs & 0.106 & $50 \%$ & 0.053 & Peanuts & & \\
\hline Sunflower & 1.5 & 0.3 & & & & & Soybeans & 60 & \\
\hline Soybeans & 0.83 & 0.25 & & & & & Sunflower & 28 & \\
\hline
\end{tabular}

\begin{tabular}{|c|c|c|c|c|c|c|c|c|c|c|}
\hline \multirow[b]{2}{*}{ County } & \multirow{2}{*}{$\begin{array}{l}\text { Crop } \\
\text { Corn Grain, bu }\end{array}$} & \multicolumn{2}{|l|}{1999} & \multirow[b]{2}{*}{ Sunflower, lb } & \multirow[b]{2}{*}{ Wheat, bu } & \multirow[b]{2}{*}{ Soybeans, bu } & \multicolumn{3}{|c|}{ Number of Animals } & \multirow[b]{2}{*}{$\begin{array}{c}\text { Sheep and } \\
\text { Lambs }\end{array}$} \\
\hline & & Barley, bu & Oats, bu & & & & $\begin{array}{l}\text { Cattle and } \\
\text { Calves }\end{array}$ & $\begin{array}{l}\text { Milk Cows/ } \\
\text { Dairy Cattle }\end{array}$ & $\begin{array}{l}\text { Hogs and } \\
\text { Pigs }\end{array}$ & \\
\hline Adams & 151,600 & 252,000 & 229,000 & $18,740,000$ & $2,467,700$ & 0 & 34,000 & 0 & 0 & 14,300 \\
\hline Benson & 323,800 & $2,718,000$ & 382,000 & $70,860,000$ & $3,879,200$ & 15,100 & 27,000 & 500 & 1,100 & 1,700 \\
\hline Burleigh & 886,200 & 468,000 & 720,000 & $37,150,000$ & $2,469,000$ & 79,800 & 67,000 & 0 & 800 & 4,700 \\
\hline Dickey & $6,765,900$ & 451,000 & 303,000 & $55,020,000$ & $2,641,500$ & 989,800 & 43,000 & 800 & 6,500 & 3,700 \\
\hline Dunn & 111,600 & 846,000 & 943,000 & $5,550,000$ & $2,666,600$ & 0 & 94,000 & 1,400 & 2,600 & 2,800 \\
\hline Eddy & 187,500 & $1,024,000$ & 129,000 & $46,510,000$ & $1,862,300$ & 0 & 16,000 & 0 & 0 & 2,700 \\
\hline Emmons & 801,600 & $1,108,000$ & $1,296,000$ & $82,380,000$ & $3,675,300$ & 114,000 & 65,000 & 4,900 & 1,100 & 0 \\
\hline Foster & 388,800 & $1,347,000$ & 117,000 & $70,980,000$ & $2,595,800$ & 115,500 & 17,000 & 0 & 1,400 & 4,000 \\
\hline Grant & 568,700 & 447,000 & 881,000 & $31,710,000$ & $2,855,000$ & 10,000 & 65,000 & 2,000 & 3,000 & 2,600 \\
\hline Hettinger & 123,600 & 367,000 & 237,000 & $18,110,000$ & $7,221,900$ & 0 & 23,000 & 1,000 & 6,000 & 2,100 \\
\hline Kidder & 843,800 & 327,000 & 659,000 & $17,240,000$ & 950,000 & 53,000 & 71,000 & 1,300 & 800 & 7,800 \\
\hline LaMoure & $3,429,300$ & $1,521,000$ & 285,000 & $89,830,000$ & $4,197,800$ & $1,773,000$ & 28,000 & 2,000 & 14,000 & 2,400 \\
\hline Logan & 258,700 & 782,000 & 535,000 & $45,210,000$ & $1,710,200$ & 52,700 & 47,000 & 1,600 & 1,000 & 1,000 \\
\hline McHenry & 126,000 & $1,452,000$ & 424,000 & $46,390,000$ & $3,077,000$ & 0 & 77,000 & 2,300 & 800 & 5,000 \\
\hline Mclntosh & 318,800 & 569,000 & 629,000 & $64,220,000$ & $1,707,800$ & 126,000 & 44,000 & 2,200 & 1,500 & 800 \\
\hline McLean & 287,800 & $1,900,000$ & 340,000 & $27,600,000$ & $10,201,700$ & 19,500 & 46,000 & 1,300 & 0 & 2,200 \\
\hline Mercer & 62,100 & 600,000 & 458,000 & $4,690,000$ & $2,272,000$ & 0 & 35,000 & 0 & 0 & 600 \\
\hline Morton & 716,500 & $1,248,000$ & $1,197,000$ & $42,870,000$ & $3,148,000$ & 15,500 & 109,000 & 7,000 & 4,000 & 5,800 \\
\hline Oliver & 91,100 & 644,000 & 521,000 & $8,220,000$ & $1,546,000$ & 0 & 45,000 & 1,200 & 2,800 & 2,600 \\
\hline Pierce & 91,700 & $1,663,000$ & 255,000 & $47,750,000$ & $2,702,000$ & 41,100 & 27,000 & 800 & & 800 \\
\hline Sheridan & 39,200 & $1,633,000$ & 254,000 & $45,120,000$ & $2,767,000$ & 0 & 22,000 & 900 & 900 & 1,000 \\
\hline Sioux & 122,000 & 35,000 & 365,000 & $7,800,000$ & 648,000 & 13,700 & 34,000 & 0 & 600 & 0 \\
\hline Stark & 70,400 & 598,000 & 671,000 & $6,650,000$ & $4,714,200$ & 0 & 60,000 & 3,100 & 4,100 & 3,200 \\
\hline Stutsman & 823,000 & $2,540,000$ & 289,000 & $128,460,000$ & $6,249,400$ & 773,500 & 61,000 & 2,900 & 2,700 & 3,200 \\
\hline Ward & 59,700 & $3,126,000$ & 234,000 & $44,480,000$ & $8,979,400$ & 0 & 46,000 & 1,800 & 2,700 & 1,900 \\
\hline Wells & 513,500 & $2,416,000$ & 207,000 & $115,200,000$ & $6,314,000$ & 44,400 & 23,000 & 0 & 0 & 1,300 \\
\hline \multicolumn{11}{|l|}{ South Dakota } \\
\hline Campbell & $1,559,000$ & & 587,000 & $48,720,000$ & $1,622,600$ & 313,000 & 39,442 & 1,342 & 2,711 & 2,757 \\
\hline Corson & 527,000 & & 756,000 & $18,355,000$ & $2,831,300$ & 0 & 68,794 & 638 & 2,139 & 4,476 \\
\hline McPherson & $1,108,000$ & & 580,000 & $36,360,000$ & $1,175,000$ & 460,000 & 71,202 & 1,756 & 30,440 & 2,105 \\
\hline Walworth & $2,151,000$ & & 328,000 & $64,160,000$ & $2,934,400$ & 466,000 & 37,227 & 458 & 12,921 & 564 \\
\hline
\end{tabular}


Collectable Residue (tons)

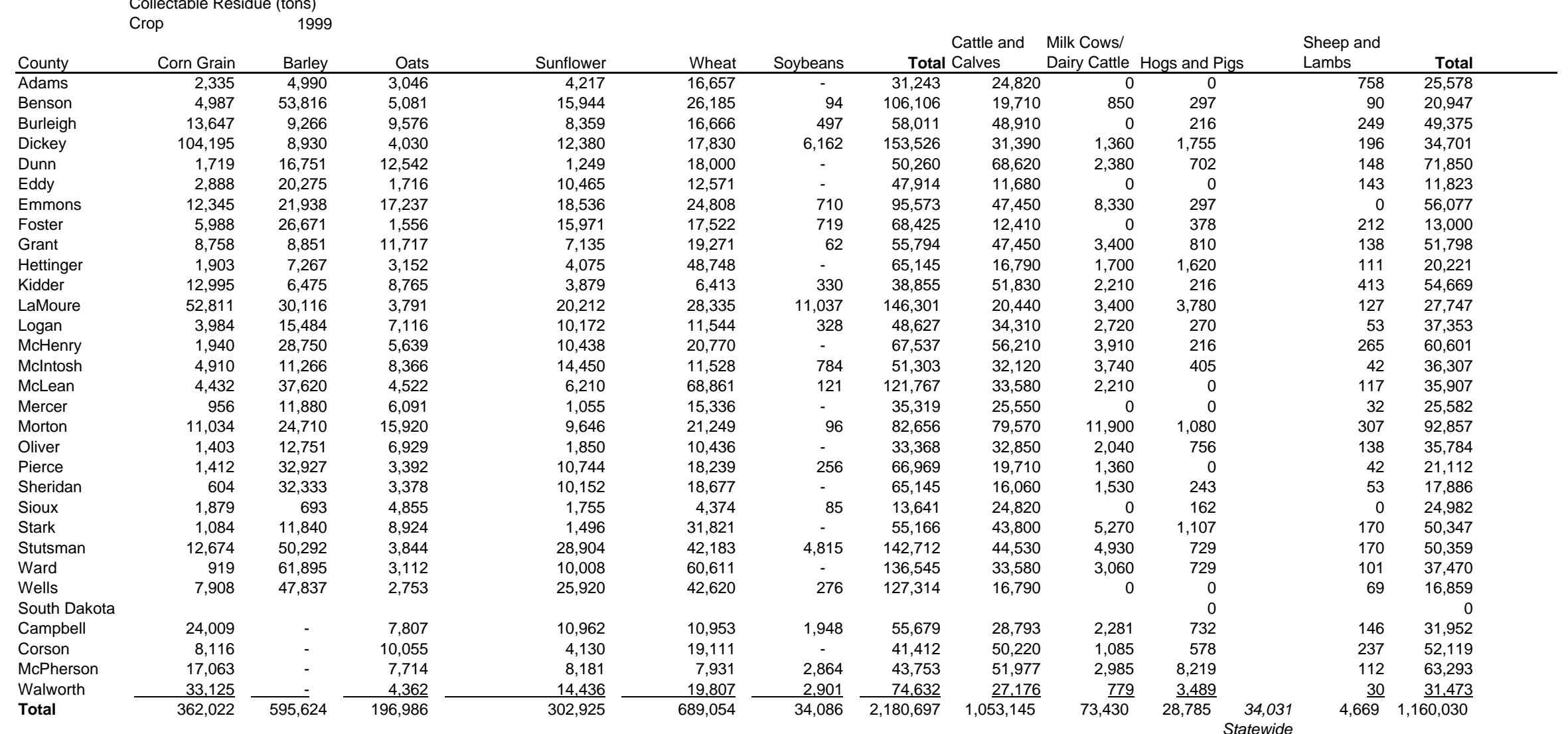


APPENDIX B

\section{EQUIPMENT SPECIFICATIONS}




\section{EQUIPMENT SPECIFICATIONS}

B-1. Process Flow Diagram 


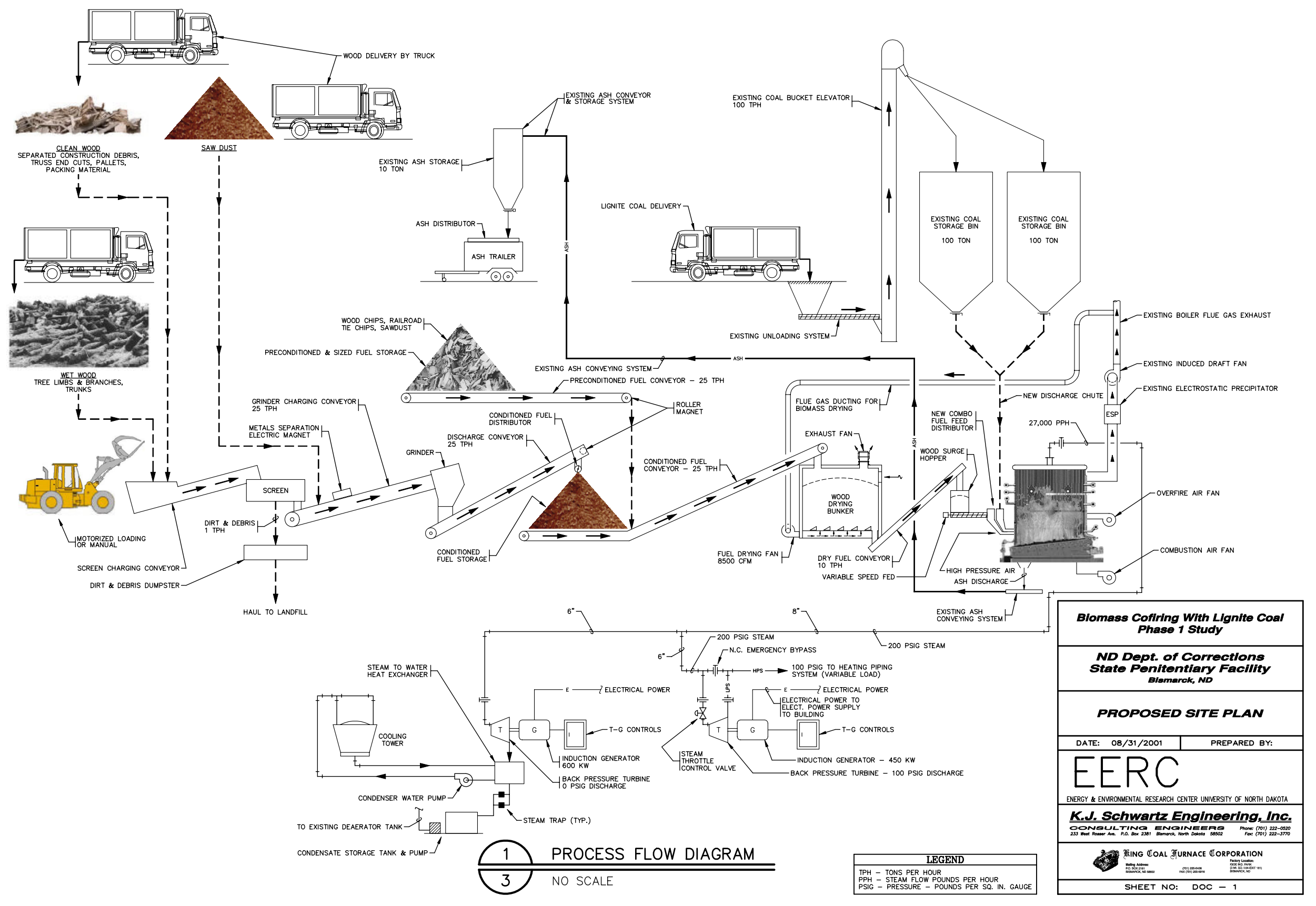


B-2. Site Plan 


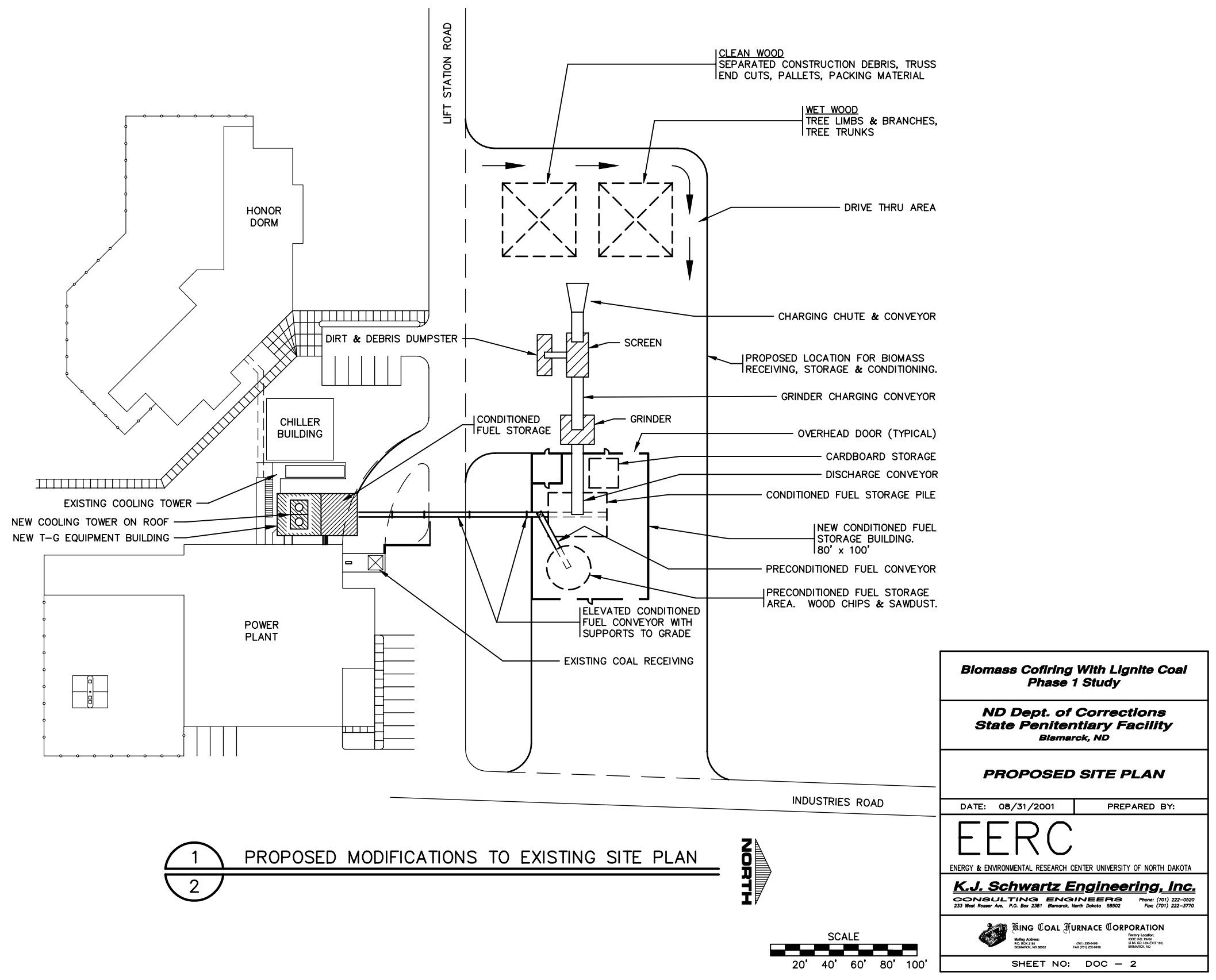


B-3. Equipment Layout 


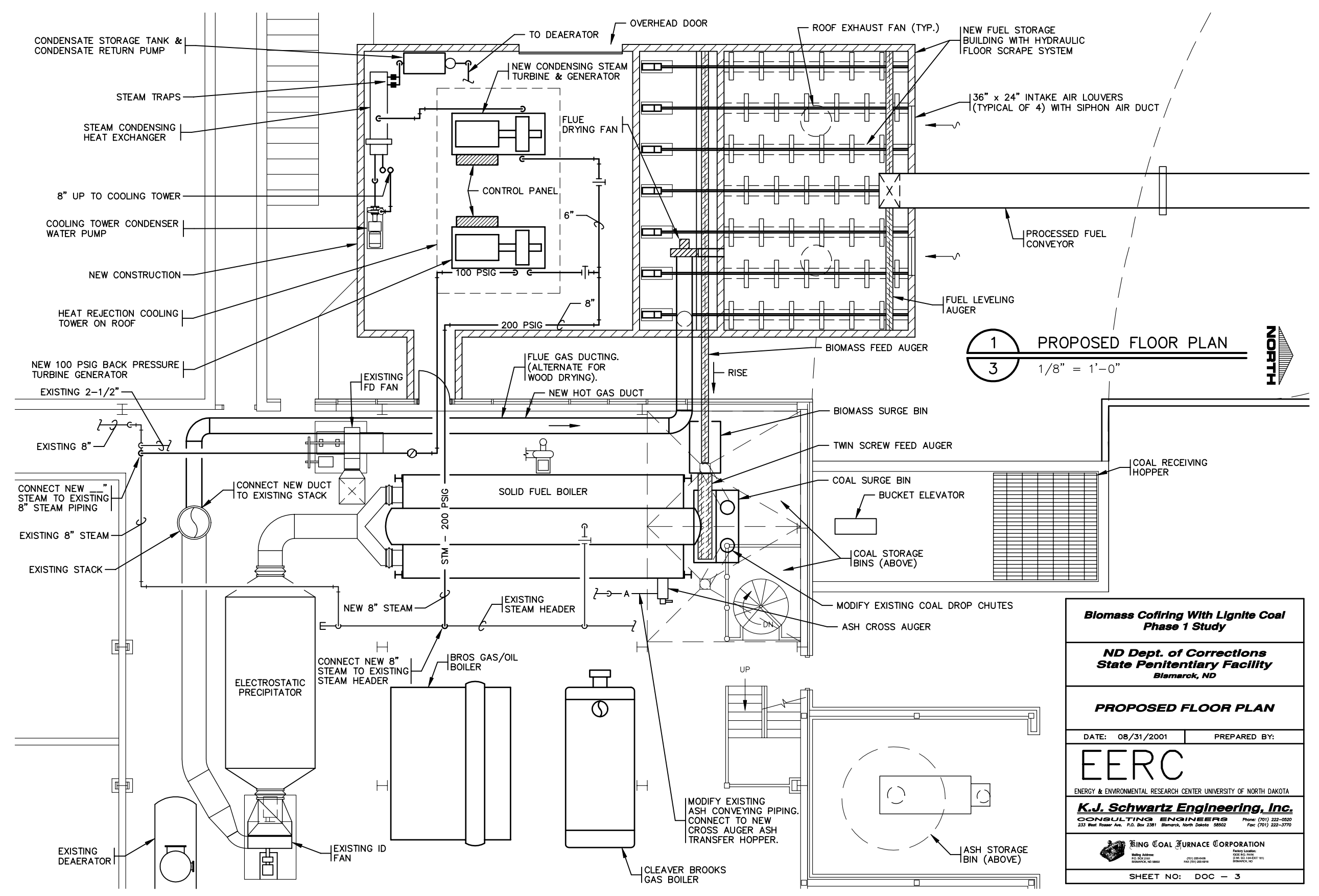


B-4. Equipment Elevation 


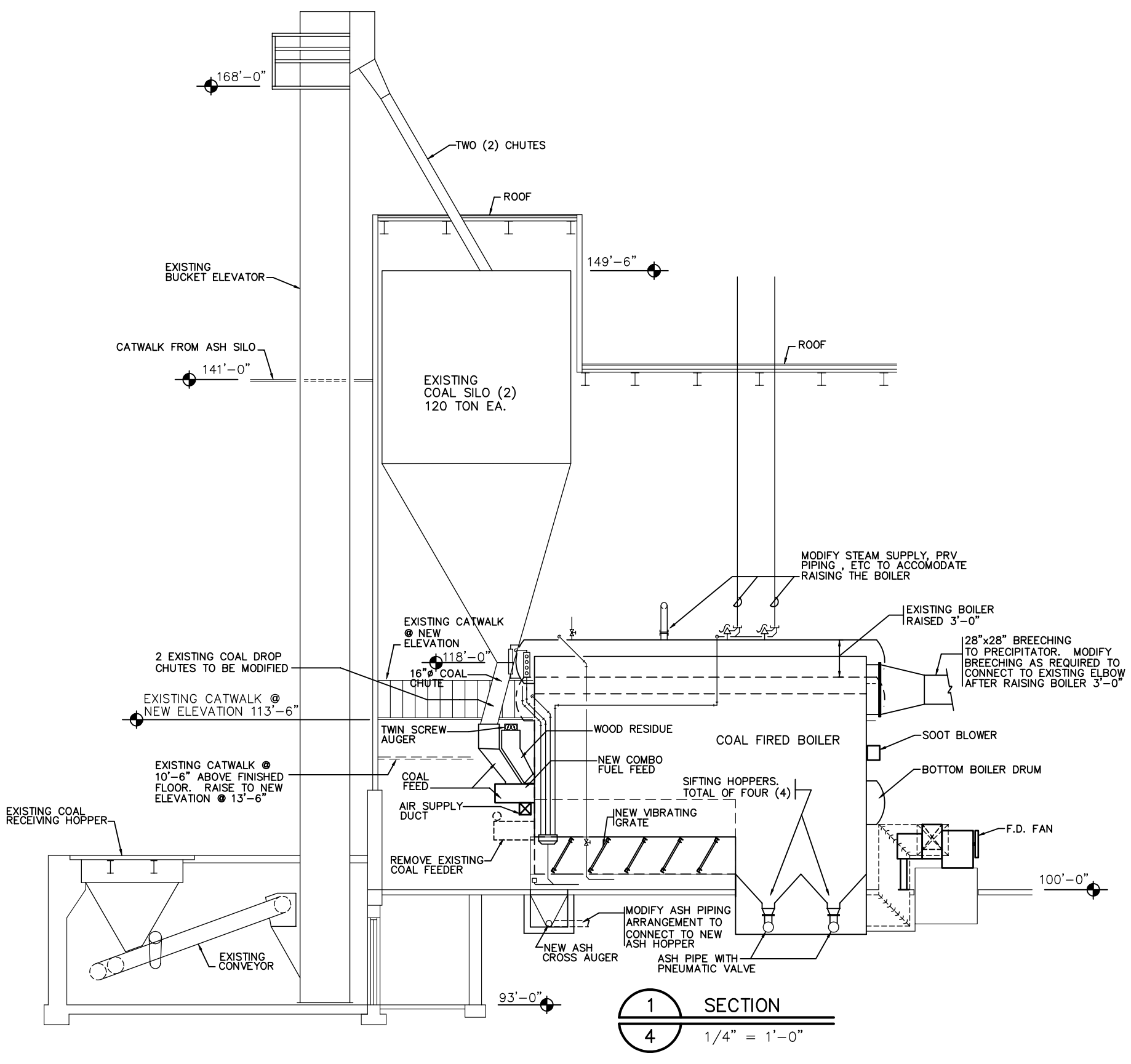

Biomass Cofiring With Lignite Coal Phase 1 Study

ND Dept. of Corrections Bismarck, ND BOILER MODIFICATION
SECTION DRAWING

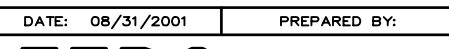
EERC 作 K.J. Schwartz Engineering, Inc.

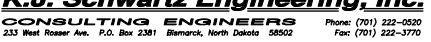

3. FING UIOAL đURNACE CORPORATION HEET NO: DOC - 4 
B-5. Equipment Specifications 
EQUIPMENT SPECIFICATIONS:

PROJECT: COFIRING BIOMASS \& COAL

DATE: $\quad$ 8-31-01

LOCATION: North Dakota State Penitentiary

Bismarck, ND

\section{FUEL PREPARATION}

Wood fuel is generally transported via trucks with 40 - or 50 -ft vans holding between 18 and 40 tons. This is the most economical way to transport bulk materials over the short distances normally traveled between fuel source and boiler plant.

Self-unloading vans, dump trucks and conventional semitrailers are used to haul wood fuel. The most economical choice for small plants requiring only a few loads per day is either the self unloading van or rear dump trucks.

The fuel unloading system is designed to unload fuel as quickly as possible in the receiving area. The system will handle the daily fuel consumption in a 4-hour period. This equals 25 tons per hour. Fuel-handling equipment will be capable of reliable operation year round under dusty conditions moving a material that is abrasive, can freeze solid, and has virtually a negative angle of repose.

Traffic flows are indicated on the modified Site Plan Sheet. Increased traffic will be necessary to deliver the quantities of fuel required. On the average, there will be two (2) to four (4) trucks per day carrying 25 tons each. Arborists or tree trimming operation and loads hauled from the landfill after sorting will also affect the number of loads, or vehicles, in the area.

\section{WOOD FUEL HANDLING}

The wood fuel is removed from the transport vehicle to storage piles for sorting, continuing to the charging hopper, and then metered to a screen that splits the stream into two fractions. Screened materials are sent to a grinder or "hog" for sizing to correct fuel size. Dirt and particles of reject size bypass the mill are conveyed to a dumpster for disposal.

Tramp iron is removed from the fuel stream by magnets. Once the fuel has been screened or sized, and the metal removed, it is conveyed to storage in the Condition Fuel building pile or to Drying Bunder building with a live bottom floor. 
Screen removes dirt from the fuel stream before entering the the wood grinder. Chosen is a vibrating type screen.

Screen Specifications:

\section{VIBRATING SCREENS}

Action Equipment Company, Inc. has received worldwide recognition for its screening expertise and has been awarded a United States and Canadian patent for various unique features of the non-blinding TAPER-SLOT®® Screen. The technologically advanced TAPER-SLOT $®$ Screen overcomes the shortcomings of other standard screening devices such as perforated screens, wire mesh screens, finger screens, disc screens, and rotary trommels. Distinctly different and unmatched in performance, the TAPERSLOT $\Theta$ Screen is a shining example of innovative screening technology that not only looks good on paper - it is technology that performs.

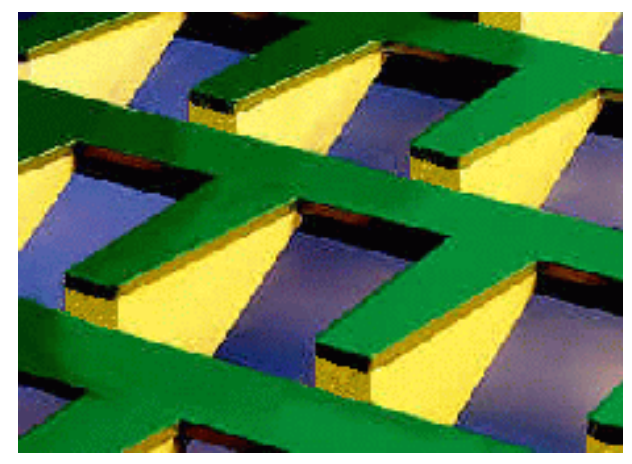

\section{TAPER-SLOT®® Screen with Patented Lateral Wedge Members}

U.S. \& Canadian Patents 5,746,322 and 2,206,981 Other Patents Pending

Unlike conventional finger screens, the highly sophisticated TAPER-SLOT® Screen offers three distinct benefits new to the vibratory industry:

1) HANG-UP ELIMINATION - Lateral wedge deflectors prevent material from shifting laterally and catching under or wrapping around finger tips, thus allowing the screen to remain clean for maximum screening efficiency.

2) ACCURATE SIZING - Lateral wedge deflectors prevent longer, often oversized materials from shifting sideways under a finger tip and falling into the accepts, resulting in more accurate sizing of two dimensional flat materials.

3) ULTRA-RIGID - Lateral wedge deflectors prevent undesirable "finger bending" and function as gussets under each finger to provide the ultimate in rigidity for long screen life.

Screen Size: 1"

Dimension: 30 ' long x 48" Wide

Minimum Flowrate: 25 Tons per hour.

Motors: 2 - $10 \mathrm{HP}$ 


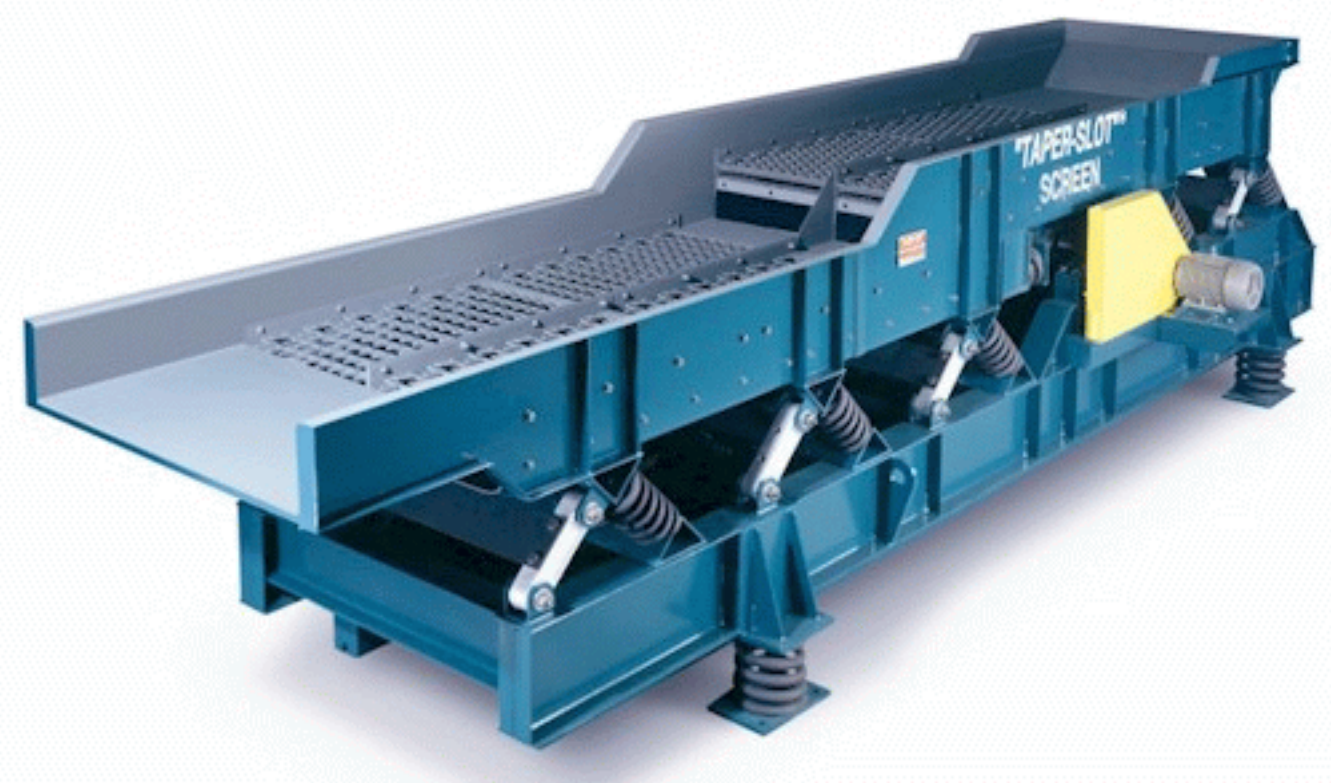

30 '-0" long x 48" wide balanced and isolated 1" TAPER-SLOT $\AA \AA$ Screen with 12 " vertical drop to remove fines from overs.

\title{
Powerful Magnetic Trap
}

The Action Magnetic Trap successfully catches small pieces of tramp helping to prevent machinery damage, costly shutdowns, spark induced fires, explosions, and reduces labor costs by eliminating the need for continual metal detector monitoring with undesirable sensitivity adjustments.

\section{Permanent Plate Separator Magnets}

Action's industrial strength plate magnets provide a permanent magnetic power source to help protect against the hazards of fine iron and tramp iron contamination in free-flowing materials.

\section{HORIZONTAL GRINDER}

Oversized wood fuel is reduced to manageable, relatively uniform pieces by shredding in a rotary mill.

\author{
CBI 3636 STATIONARY \\ BIOMASS RECOVERY SYSTEM \\ Electric
}


EQUIPMENT: $\quad$ CBI 36 X 36 GRIZZLY MILL

\section{MAIN FRAME}

S Consists of Upper and Lower Housing. All cross members formed and $100 \%$ welded. All stress relieved for maximum life and strength. Main Frame line bored and all holes equipped with replaceable bushings.

S Equipped with four lifting eye brackets.

\section{ROTOR (Offset Helix)}

S Solid Steel Rotor made of machined plate, welded together to make one unit with four alternately angled rows of rebuildable / replaceable Striker Plates.

S Rotor Diameter complete is 36".

$S$ Rotor Length is 60".

$\mathrm{S}$ Rotor locked to shaft by Ringfeders.

\section{STRIKER PLATES (20 pieces)}

S Machined plates made of $400 \mathrm{BHN}$ Abrasive Resistant alloy and hard-coated with tungsten carbide.

S Weight $=35 \mathrm{lbs}$. each.

\section{$\underline{\text { SHAFT }}$}

S Made of high strength alloy 6" diameter.

S Drilled and tapped in both ends for bearing, bearing sleeve removal

\section{BEARINGS (2)}

S SKF 22234 Spherical Roller Bearings 


\section{BEARING HOUSINGS}

S Machined of thick steel plate recessed into side plates for exact positioning and full support. Bolted on to main frame. Grease filled.

$\mathrm{S}$ One fixed and one floating.

S Labyrinth seal on inside.

S Lip seal on outside in removable bearing cap.

ANVIL

S 5" thick, supported at the top with 2" hinge pins, drilled and tapped for pull hammer. and at the bottom with 2" diameter shear pins machined to suit the application.

S Anvil equipped with adjustable blocks to support shear pins, allowing anvil / rotor clearance to be adjusted, and shear pins to be easily replaced.

$\mathrm{S}$ Anvil equipped with lifting eye bracket.

\section{ANVIL LINER}

S Made of 1114 " thick, 500 BHN Abrasive Resistant alloy. - Liner bolted to the Anvil.

\section{SIDE LINERS}

S Made of .625" thick, 400 BHN Abrasive Resistant alloy, bolted in place. - Liners cover $100 \%$ of the wear area.

S Top and Bottom sideliners can be removed with rotor in place.

\section{GRATE}

S Designed for super high strength and the industry's longest life.

S Grate Liner made of 1.25" thick, 400 BHN Abrasive Resistant alloy, 180 degree cutting surface with diamond holes for maximum throughput.

S Supported by four 1.5" pins equipped with shear groove.

$\mathrm{S}$ Adjustable in two positions.

$\mathrm{S}$ Grate available in various sized openings.

\section{HYDRAULICS}

Two hydraulic Cylinders for opening the Upper Housing to access the Rotor. Cylinder Bore 4" x Rod 2" x Stroke 14"

\section{BONNET}

The Chute includes the Grizzly Mill feed chute (bonnet over mill) of 1/2"- 3/8" plate construction with flat bar stiffeners on the outside. The chute will match feed conveyor head end section. Primed and painted CBI yellow. 


\section{BASE}

Base to tie together mill and motor with adjustable motor platform. I-Beam frame to tie together Hog, motor, hydraulic power unit, discharge conveyor, as well as, supporting feed conveyor designed to be placed on elevated concrete pad/foundation.

\section{POWER UNIT}

One, $400 \mathrm{HP}, 480 \mathrm{~V}$, TEFC high efficiency, TECO motor.

DRIVE Complete V-belt Drive including belt guard.

\section{FEED CONVEYOR}

60 " wide $\times 40$ ' long belt with heavy structural steel conveyor frame with 18 " deep sides and 8'x 10' loading hopper. Cross members under conveyor bed; 1/4" plate in bed under conveyor belt at loading end. The conveyor belt is to be heavy-duty impact resistant. Drive to be large diameter, 3/8 lagged pulley with a 2 15/16 shaft with a Dodge gearbox with 10 HP. Heavy-duty tail pulley with take-up brackets on pillow block bearing. Four, 4" diameter heavy-duty return idlers to carry conveyor belt. Conveyor to have hood section built-on head pulley end to fit hood section on hog.

\section{HYDRAULICS SYSTEM:}

A $20 \mathrm{HP}$ electric motor mounted on a 120-gallon hydraulic tank with filters. Variable displacement piston pump for feed conveyor and mill opener. Two-directional electric over hydraulic solenoid valve for feed conveyor. Manual valve bank for mill opener. Oil cooler.

\section{DISCHARGE CONVEYOR:}

The 60" x 40' Discharge Conveyor complete as follows: the conveyor belt rides in a steel trough protected with liners; cleated belt \#220 - 2 ply; head pulley with shaft and bearings; self-cleaning tail pulley with shaft and bearings; return idlers; and screw takeups. The drive guard and tail pulley guards are included. The head pulley is powered by an electric motor through gearbox. 

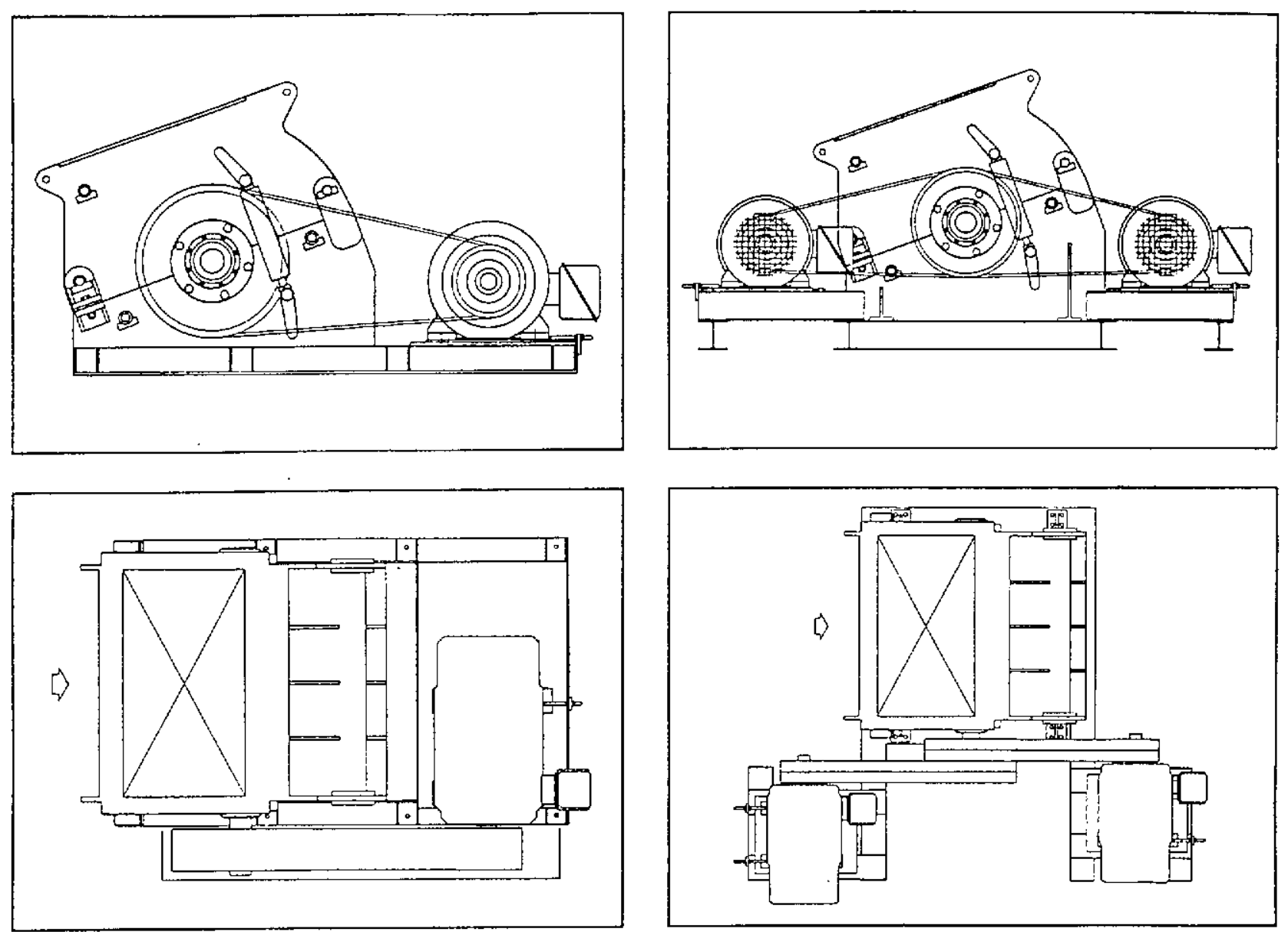

\begin{tabular}{|c|c|c|c|c|c|c|c|c|}
\hline $\begin{array}{l}\text { Mill } \\
\text { Size }\end{array}$ & $\begin{array}{l}\text { Rotor } \\
\text { Dia. }\end{array}$ & $\begin{array}{l}\text { Rotor } \\
\text { Lgth. }\end{array}$ & $\begin{array}{l}\text { Rotor } \\
\text { Wt. }\end{array}$ & $\begin{array}{c}\text { Total } \\
\text { Weight }\end{array}$ & RPM & $\begin{array}{l}\text { HorsePower } \\
\text { Electrical / Deisel }\end{array}$ & Shaft & $\begin{array}{c}\text { Capacity } \\
\text { TPH }\end{array}$ \\
\hline $36 \times 36$ & 36 & 36 & 6470 & 16600 & 750 & $200-300$ & 6 & 25 \\
\hline
\end{tabular}

Note: Specifications are to be used as a general guide. HP and Capacity figures are based on log yard debris and will vary depending on materials to be processed and desired size of finish product. 


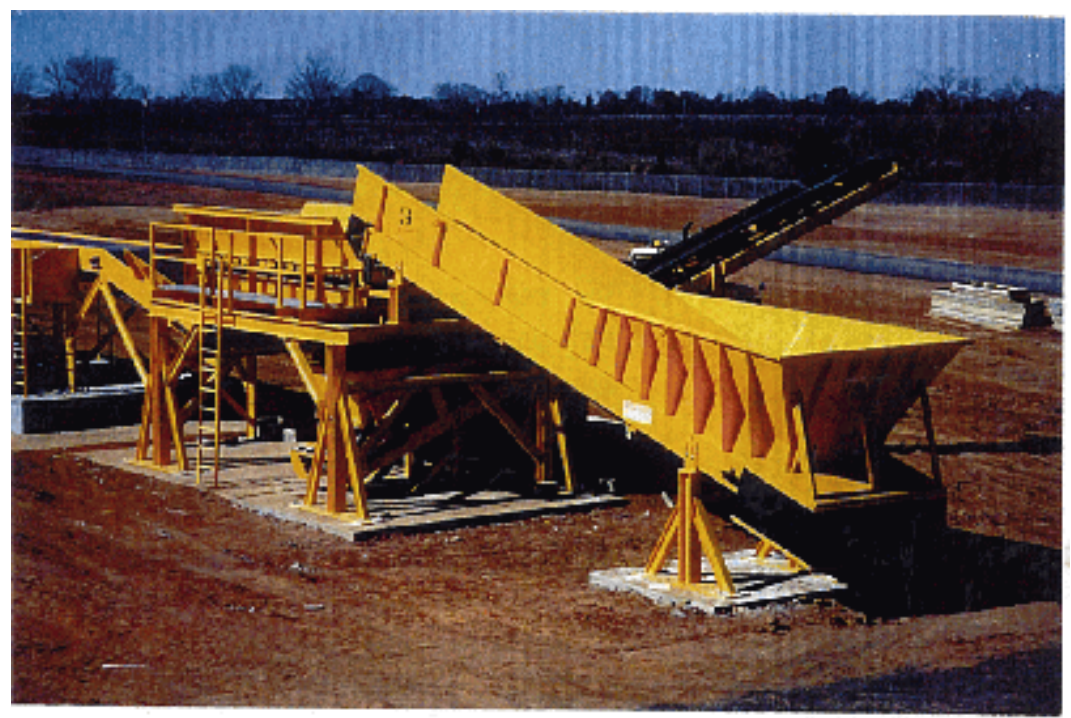

\section{MECHANICAL CONVEYORS}

Mechanical conveyors selected include belt, drag, and twin screw conveyors.

A. Belt. Fuel will be transported from the fuel processing area to the storage/drying building by belt conveyors because they are less costly to operate, can carry fuel of all sizes and quality, have high carrying capacity, can be installed over virtually unlimited distances, can be easily maintained and repaired, and are highly reliable.

RAPAT CTR 40024 CONVEYOR

- 400' Mild Steel Conveyor 6" x 8.2\# Structural Channel

- 24" Wide Rubber Belt 220 PIW

- Precision 18" Vulcanized Head Pulley with 10: Snub Pulley

- Precision 14" Tail Pulley

- Dodge S-2000 Head and Tail Bearings

- Precision CEMA C 5" Diameter 35 Degree Idlers on 4' Centers

- Precision CEMA C 5" Diameter Flat Return Idlers on 10' Centers

- 2 15/16" Drive Shaft

- $27 / 16 "$ Tail Shaft

- 14 Gauge Tail Pulley Guard

- Full Galvanized Smooth Covers

- Skirting 20' @ Inlet

- Emergency Stop Switch with Full Length Cord

- Suspended Gravity take-up

- Painted Grey Enamel

- Rated Capacity 10 TPH @ 35 PPCF

- 7.5 HP TEFC Three Phase Electric Motor

- Dodge T 4 Shaft Mount Reducer

- Catwalk and Supports Desinged to Span 50' Running form Grade to a 35' Discharge Height 
B. Drag. 12" wide drag conveyors are also capable of handling a wide variety in the quality and quantity of wood fuel, and they are located in the fuel stream where unprocessed fuel enters the system-between the fuel receiving and the screen and grinder and the fuel storage to the conveyor feeding the active storage and drying. Units to have box-link chains in single strands. Unit will work on inclines up to 20/, have modest power requirements, and can take more abuse (such as overloading) than other conveyors.

C. Screw. Twin screw conveyors are often used as feeders to the fuel-metering bin at the boiler front. With sufficient care, screw conveyors operate with a high degree of reliability.

\section{Twin Screw Conveyor - Boiler Fuel Feed}

S $3 / 8$ " thick flighting - $51 / 2$ " diameter contra rotating

S Housing Dimensions: 14" x 8".

$\mathrm{S}$ Electric Motor: $5 \mathrm{HP}$

$S$ Variable Frequency Drive Speed Control

S Interconnect to Boiler Control Panel

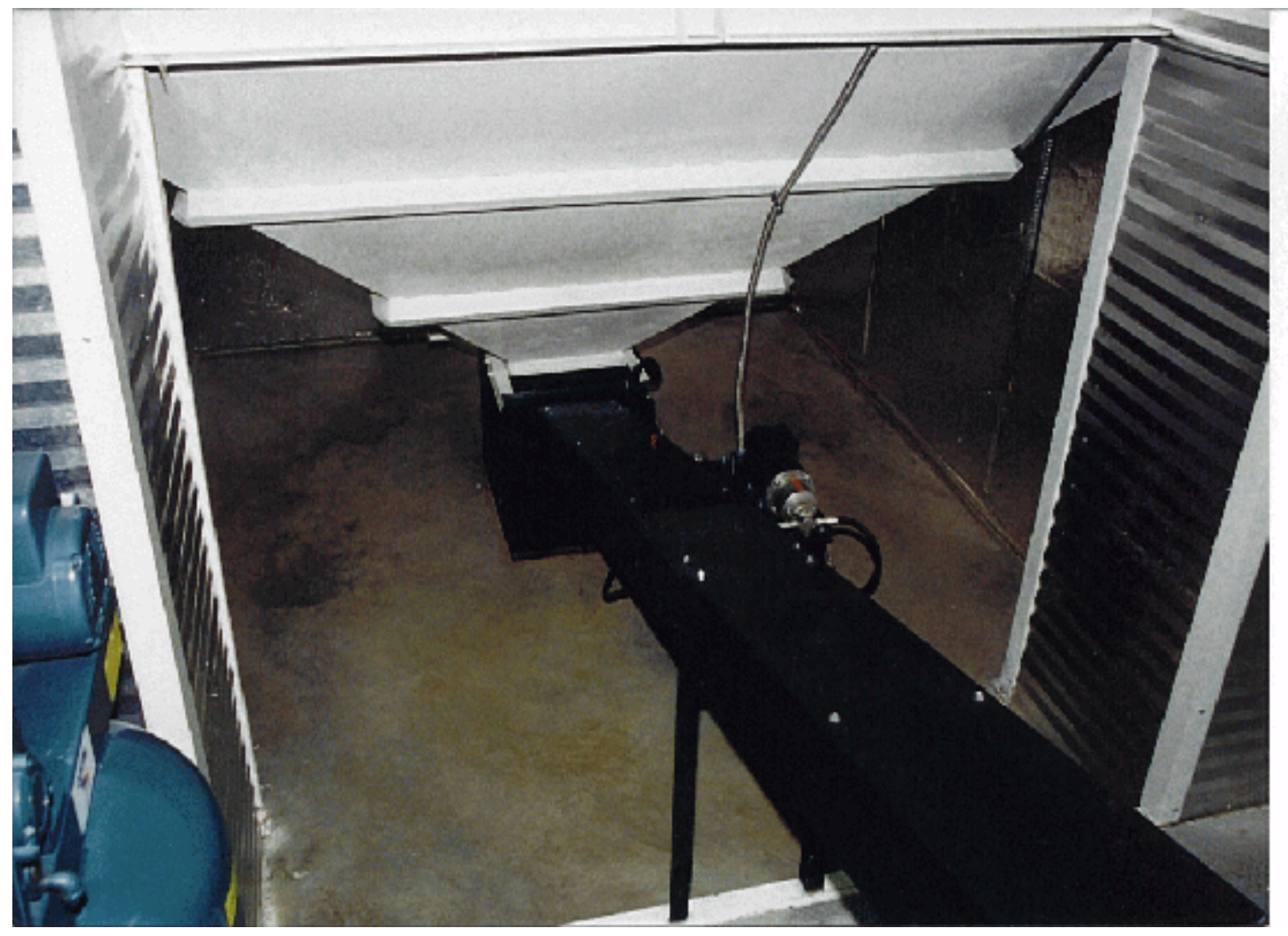

TWIN SCREEN AUGER FOR FUEL FEED 


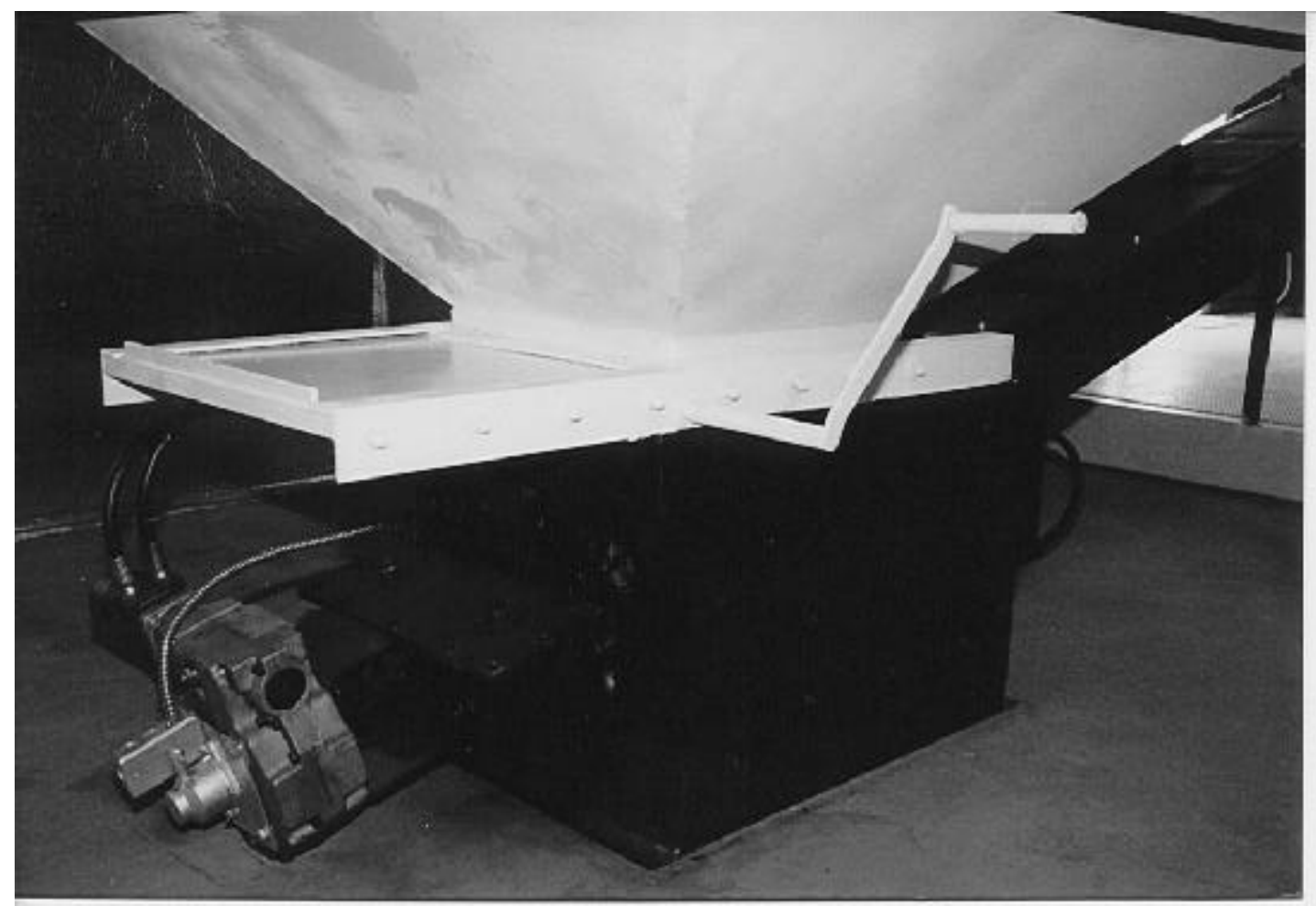

TWIN SCREW PICKUP AT BIN DISCHARGE

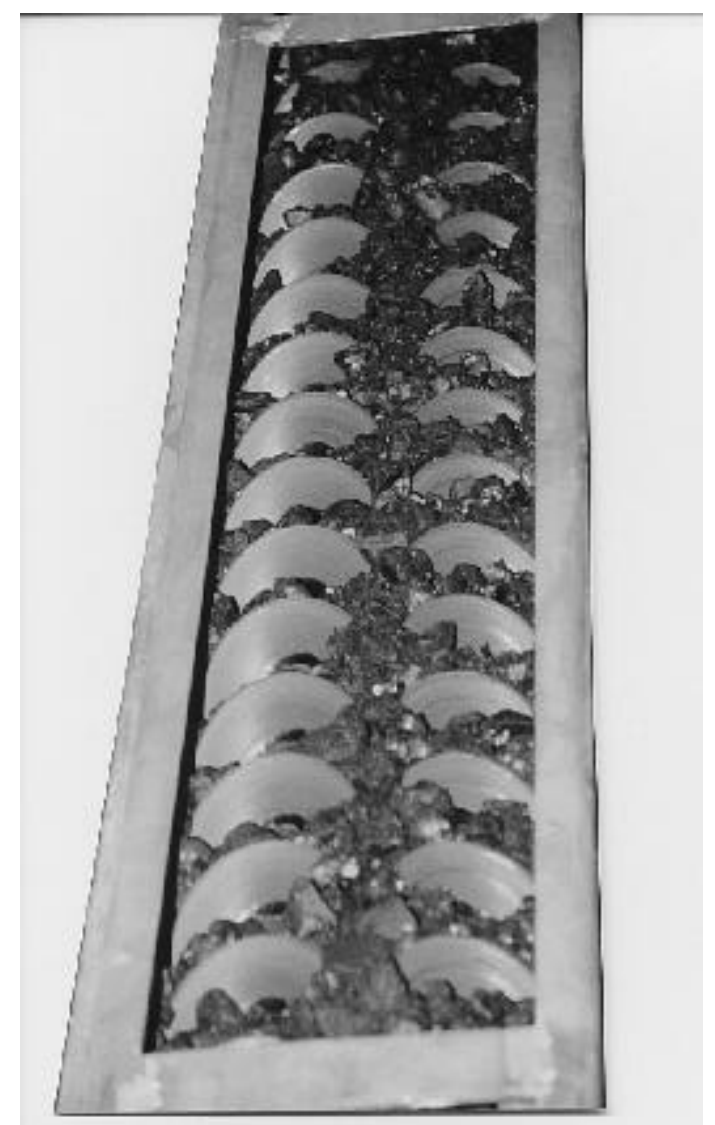

TWIN SCREW AUGER - CONVEYING FUEL (TOP COVER OFF) 


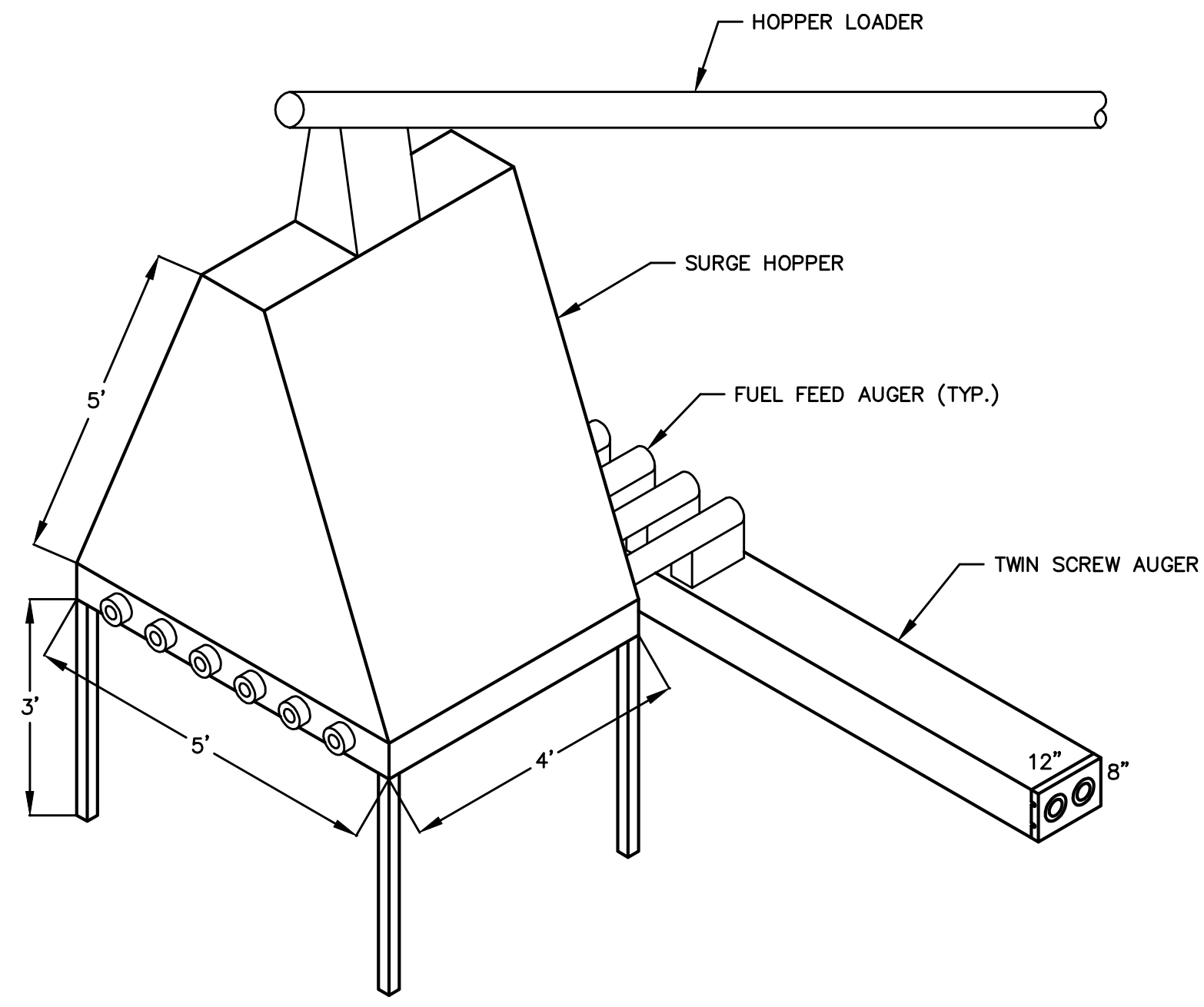

BIOMASS SURGE HOPPER \& TWIN SCREW FUEL FEED 


\section{RAPATSPREEER \\ THECOMPEELYENCOH \\ TRQGHNGOIRCONET}

With today's tight safety regulations and environmertal concerris, completely enclosed conveyors are becoming more common. Whether it is to reduce environ. mbrial vanlarnimauls, provide a äaler working environment for employees, or to maintain the integrity of ynur produrts hy reducing cortomination, the Rapel ECTR line of heavy-duty conveyors have the falures you're lonking for.

No matter what your material handling or Wheral capacity requirements, Rapat has a system that is casily and affordably custom ta lored to suit your reeds.

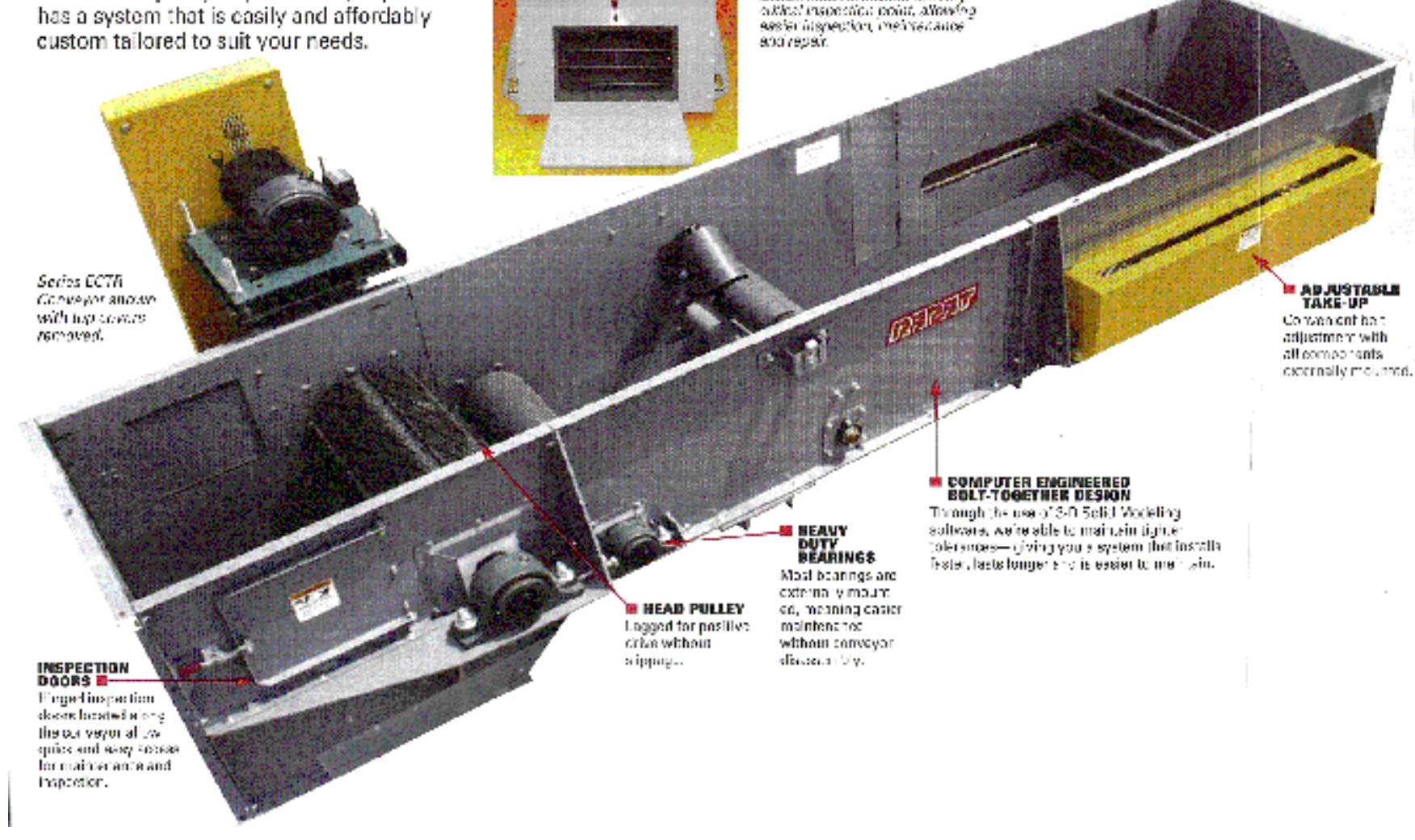

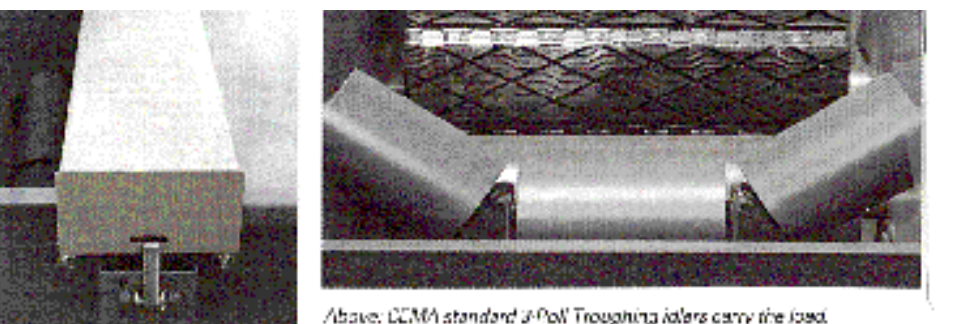

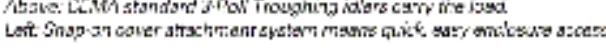

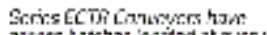

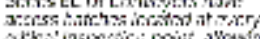

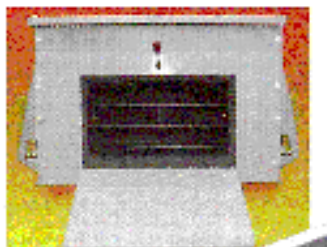

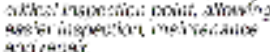

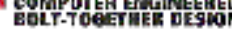

(1)

DUININGs

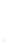




\section{WTEYE GOT YOU COUERED}

Different installations have different requirements. Maybe you would like to keep the wind and weather away from your product, and raquire cnclosure on the sides and top only? Our ECTR Conveyor will suit you perfectlyl Or perhaps your installation is in a dust-sensitivo area, and you need to keep potentially hazardous dust to a minimum - requiring a fully enclosed and sealed conveyor. In this instance the Rapat ECTR conveyor will provide the containment you need without sacrificing durability or performance.

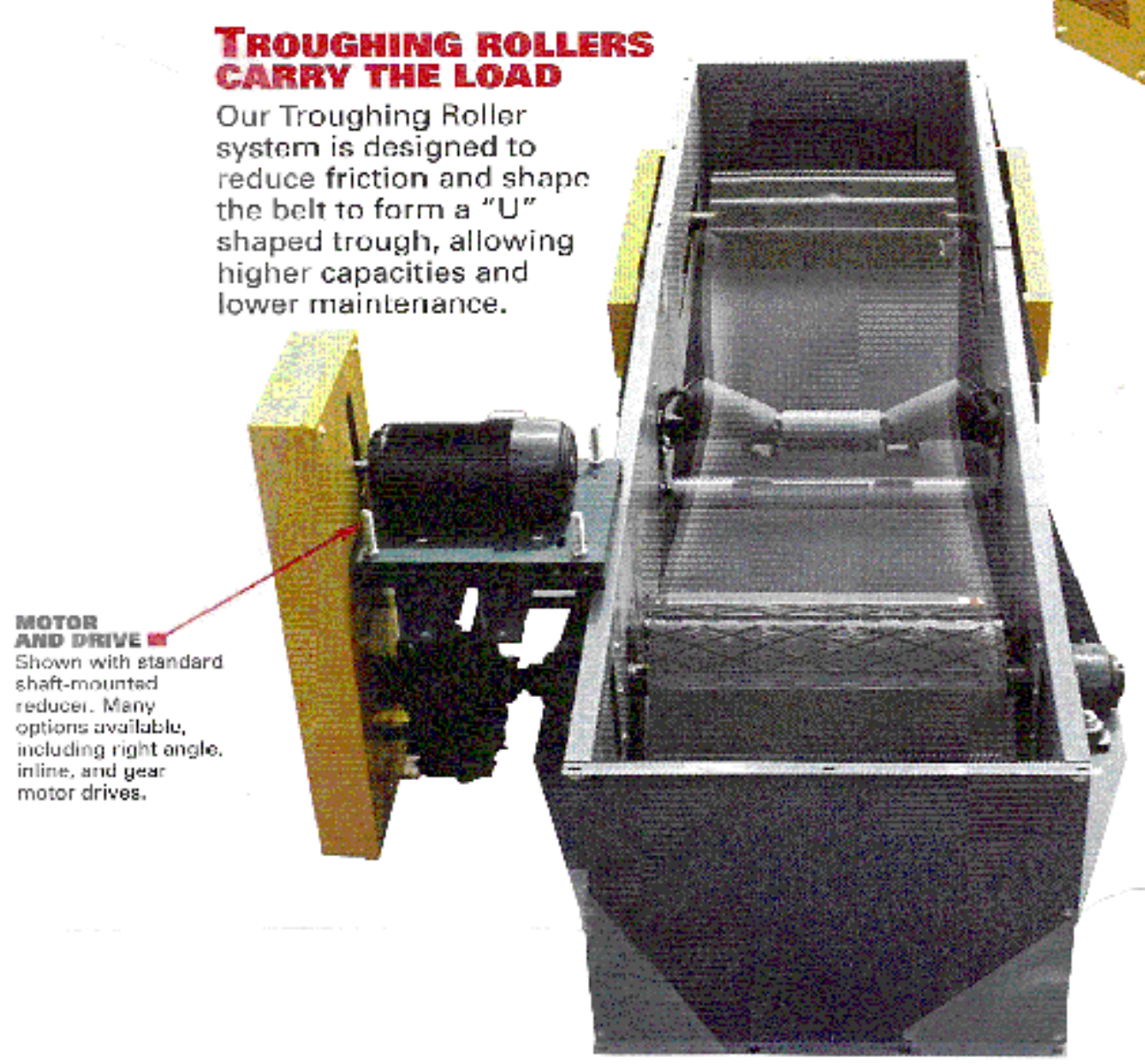

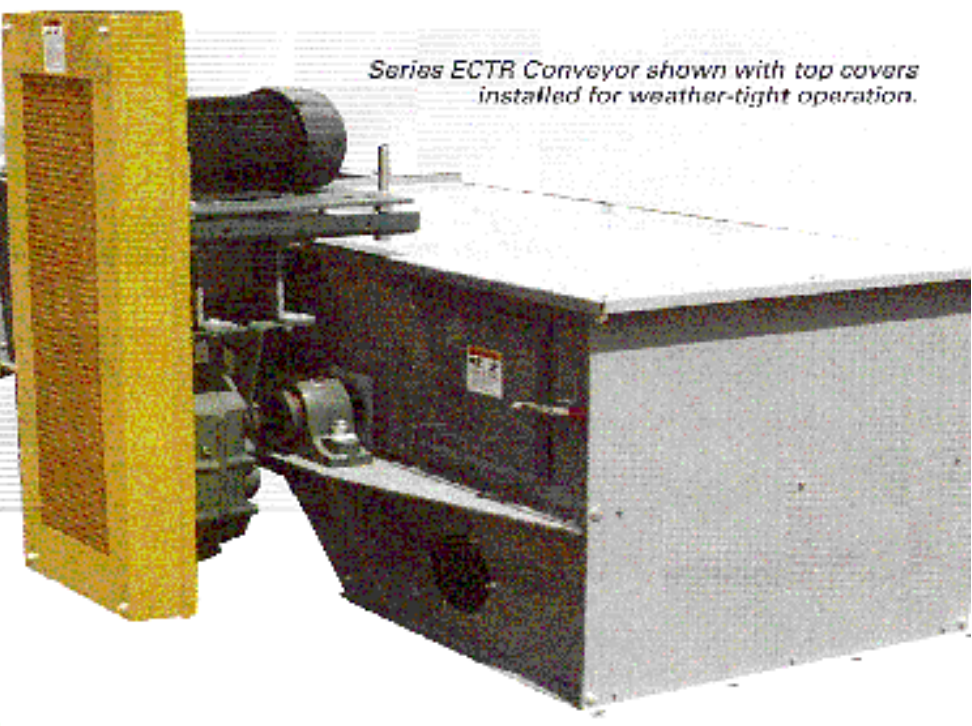

\section{SERHES ECTR FEATURES}

- Enclosure keeps dust and emissions contained within the enclosure for a safer. cleaner work environment.

Inspection doors located at head and tail as woll as throughout the enclosure to provide quick, simple access for inspection, cleanout and maintenance.

Allows for dusty, dirty or dangerous products to be moved without affecting the environment immediately surround. ing the conveyor.

Can be supplied with or without bottom covers for a partially enclosed or totally enclosed system.

울 Utilizes CEMA standard components such as carrying $\&$ return idlers and head and tail pulleys.

Conveyor frame is built in $10^{x}$ sections fo easy handling, shipping and installation. Each 10' frame section is jig welded with structural angle flanges to ensure a strong, square fit consistently on every section.

ail Head \& tail shafts are sealed with UHMW \& felt seals to prevent excess dust and product from escaping through the shafts. 

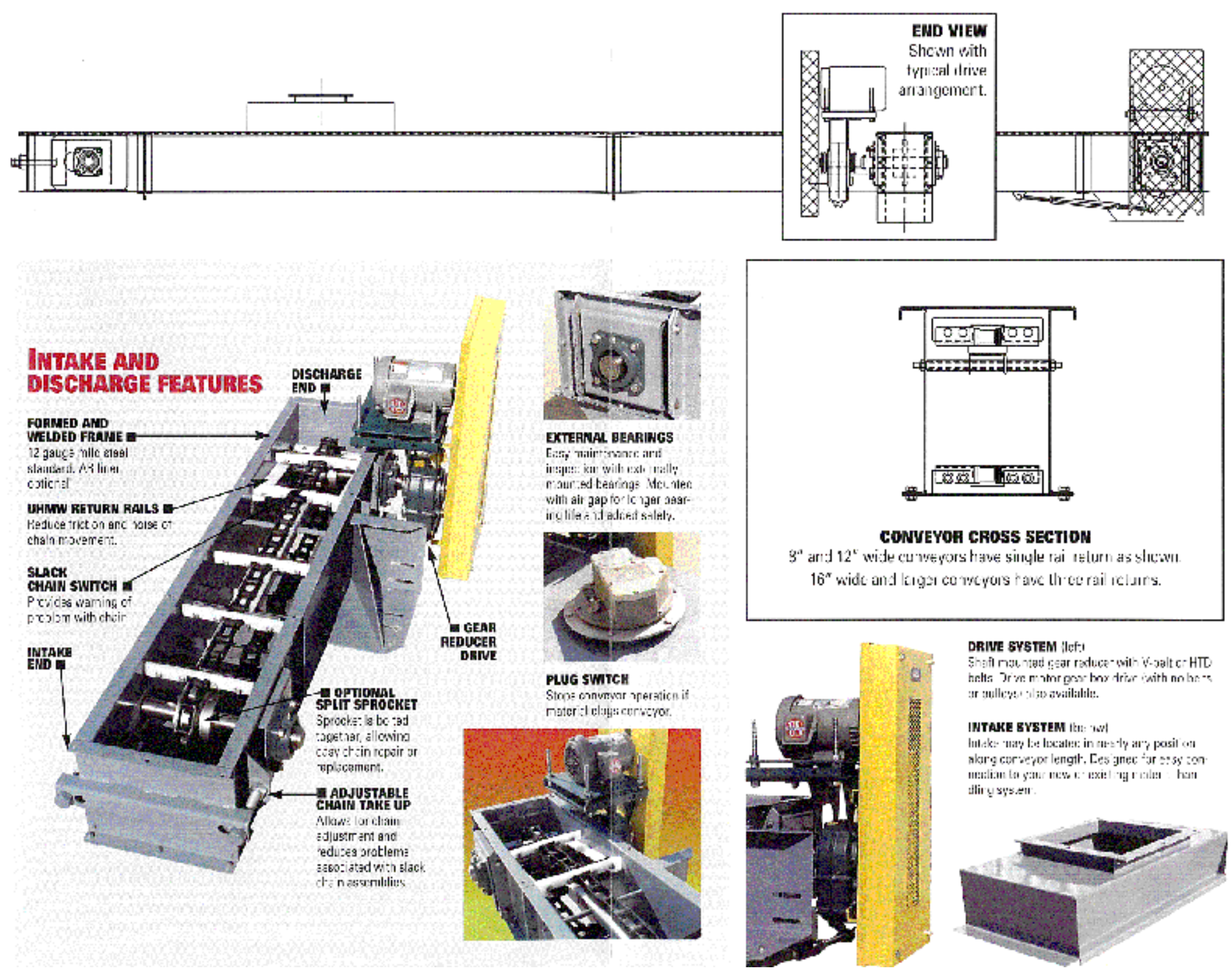


\section{BUNKER DRYING AND LIVE BOTTOM FLOOR FUEL HANDLING}

Before any fuel can burn, the moisture it contains must be evaporated. Virtually all biomass fuel steam generators have furnaces designed to drive off all the water from wood with moisture contents up to 55 percent moisture content wet basis (mcwb). But with moisture contents any higher than that, combustion becomes problematical.

One solution is to cofire a higher-quality solid fuel such as hardwood chips, coal, tirederived fuel, or hogged pallets and reels. The existing boiler is designed for this cofiring, however, the stoker must be replaced.

Preheating all combustion air (underfire, overfire, and fuel distributor air) will enable the boiler to burn up to 60 percent moisture content.

This system will use hot flue gases to dry green fuel by direct or indirect contact to 40 percent mcwb or lower. Excess heat in flue gases is also used in the preheating of combustion air.

Wood fuel is stored in the Bunker Drying bin and the conditioned and pre-conditioned fuel poiles. The quantity of fuel processed is designed to sustain boiler operations through a weekend.

Boiler feedrate @ 2500PPH steam flow is 4300 LB/HR (2.55 Tons/Hr).

Fuel active storage volume $=2.55 \mathrm{TPH} \times 3$ days $\times 24 \mathrm{Hrs} /$ Day $\times 50 \%$ mix coal and biomass $=91.5$ Tons.

A significant benefit of storing fuel for 2 to 4 weeks before firing is moisture content stabilizes so that the fuel has a much more consistent heating value. This more consistent fuel allows the combustion controls to maintain much lower $\mathrm{CO}$ and NOx, emissions.

Fuel seasoned for 2 to 4 weeks produces fewer material-handling problems.

Processed Fuel could be stored in the long term storage pile located in the proposed new building.

The Bunker Drying building will be constructed from masonry materials and concrete with precast concrete roof. This construction method minimizes steel or other metals subject to rust and corrosion from high moisture. 


\section{Processed Fuel Storage and Handling Structure}

Titan Series 3 Building include the following:

- $80 \mathrm{FT} \times 100 \mathrm{FT}$

- Patented 12.5 ounce flame retardant DuraWeave II polyethylene cover

- Trusses consist of 4" diameter tubes spaced 32" apart and strengthened by 1.9" continuous webbing

- 20 ' on center arch spacing

- 30 lbs. Roof snow load, $110 \mathrm{mph}$ wind load

- Choice of color

- Two endwalls with steel support system and fabric

- 4 - 16' x 16' Duratrac doors installed (2 per endwall)

- 4 - walk through service doors installed

- Labor installation and equipment

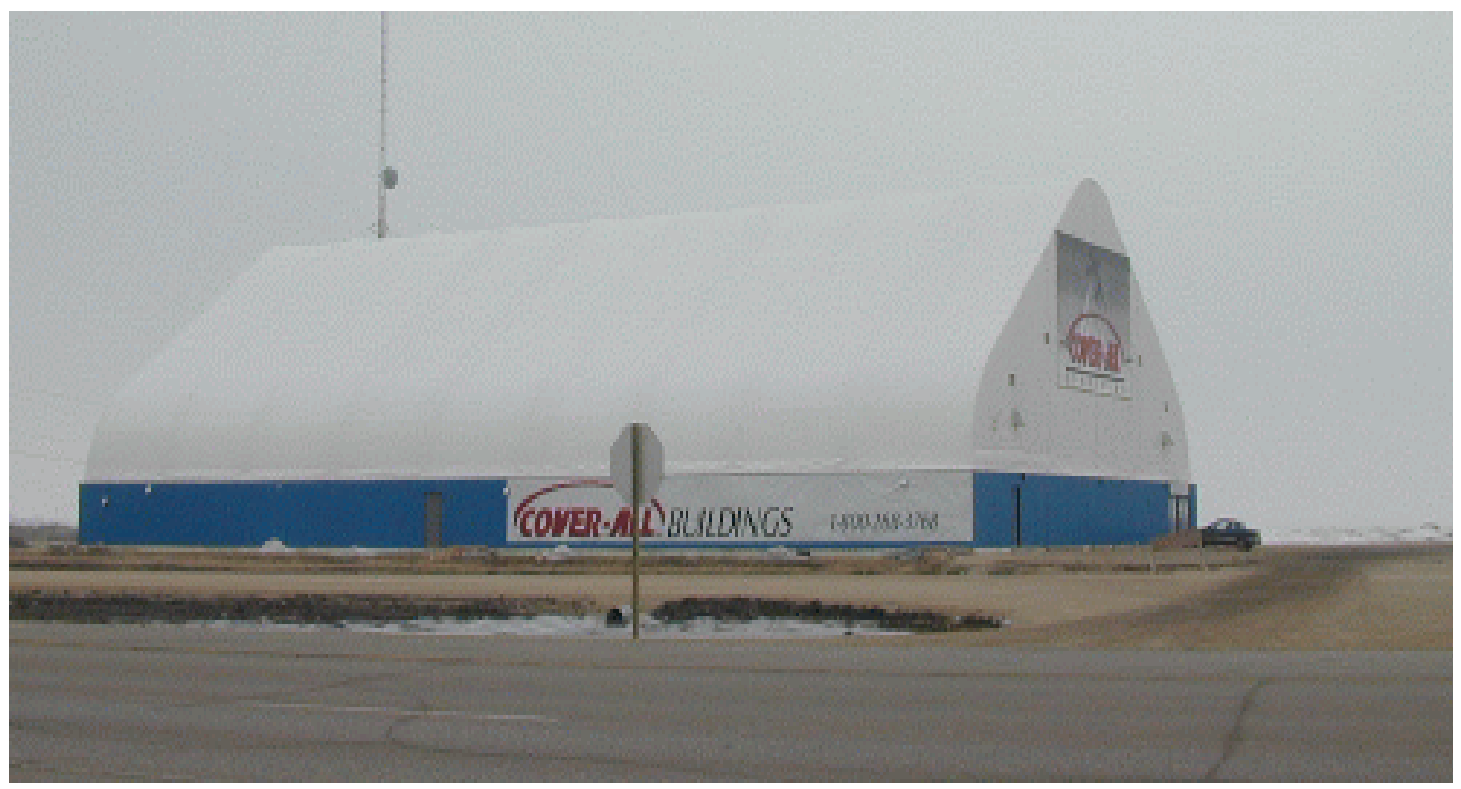

PROPOSED PROCESSED FUEL BUILDING STYLE

The boiler fuel feed system, which transfers wood from storage to fuel stokers, is a critical component of the powerplant. It must reliably deliver a controlled amount of fuel to the fuel feeders consistent with signals from the combustion controls. It must also prevent tramp air from entering the furnace via the fuel distributor.

Wood-fired plant will incorporate a live-bottom metering bin holding about 20 min worth of fuel $(1100 \mathrm{lb})$ and located at the boiler. Multiple screws will discharge fuel into the stokers at a rate determined by the combustion controls. 


\section{WOOD DRYING SYSTEM - MODULAR FUEL HANDLING \& STORAGE}

Project: DOC State Pen

Location: Bismarck, ND

Prepared by: K. J. Schwartz Engineering, Inc

Date:

08/27/2001

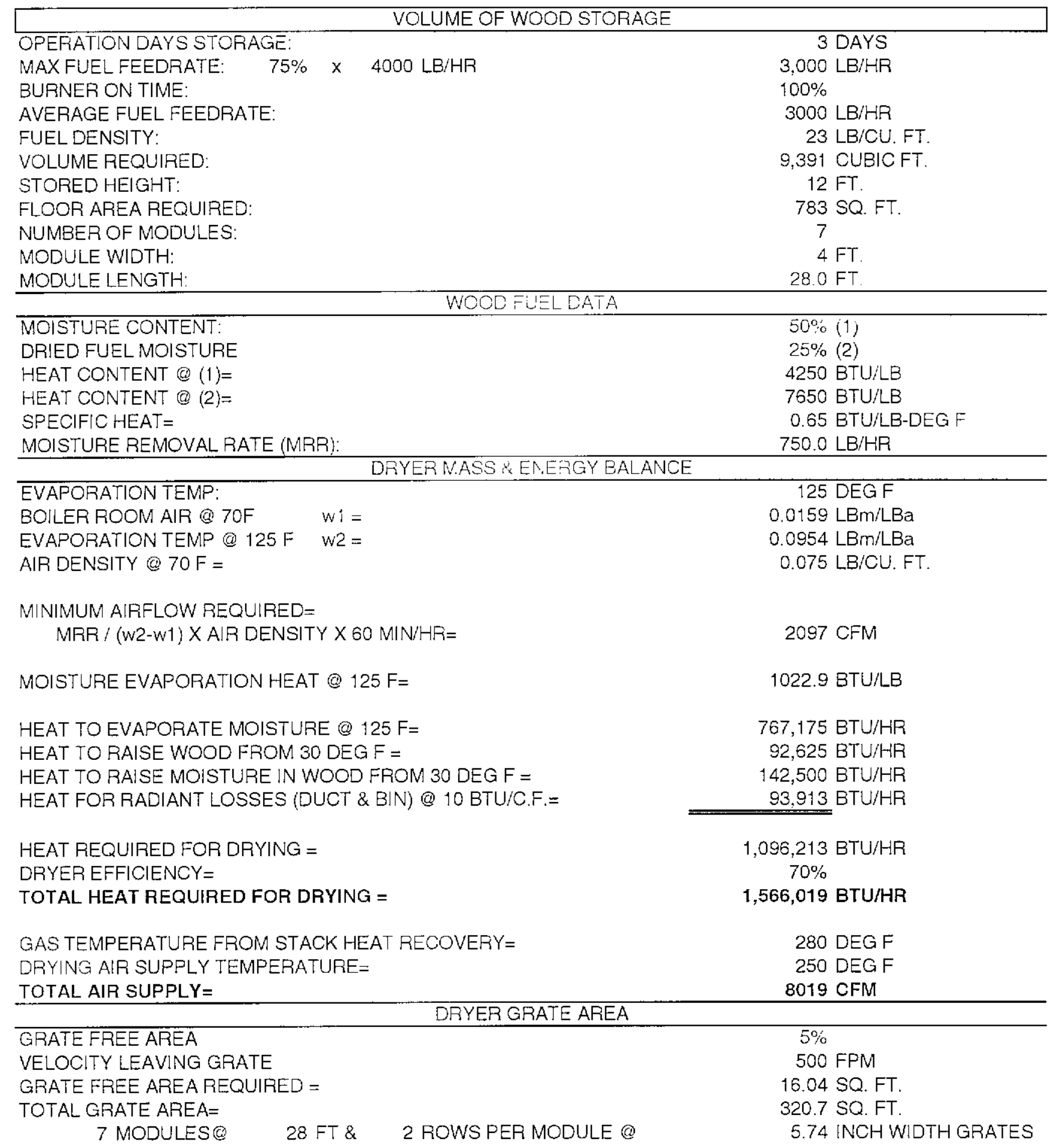




\section{COMBUSTION}

The burning process is divided into three phases: evaporation of moisture, distillation, and oxidation of volatiles and fixed carbon. In other words, the fuel absorbs heat which first drives off water and then drives off hydrocarbons, hydrogen, and carbon monoxide, which burn and sustain the combustion reaction. When most of the volatile elements are gone, the highly reactive surface of the remaining fixed carbon is oxidized.

\section{Semisuspension Firing}

Also known as spreader stoker firing, semisuspension burning involves distributing hogged fuel along with coal over a grate installed in the bottom of the furnace. Some of the fuel is consumed in suspension, but the larger, wetter fuel pieces land on the grate where they burn in a thin bed. The type of distributors or spreaders are four types of grates.

- Fuel distributors are most commonly designed to use medium-pressure air, preheated combustion air from the overfire air system, to propel fuel into the furnace. A combination feeder will be installed to replace the existing mechanical fingers distributors.

- Vibrating water-cooled grates are easier to maintain, permit cofiring of other solid fuels; feature continuous ash discharge. and rapid load response; allow very high combustion air temperatures; and enjoy very high grate heat-release rates.

\section{Combustion Air}

Bone-dry wood fuel requires less air than other carbon fuels because a significant amount of oxygen is chemically bound in cellulose. [In fact, the theoretical flame temperature of bone-dry wood fuel exceeds 3600/F (1982/C).J However, in practice, all hogged fuel boilers require relatively large amounts of excess air to drive off the water in green fuel. Theoretically, 25 to 35 percent excess air is possible, but the combustion air system is sized for 50 to 60 percent excess air to accommodate the lowest qualityavailable fuel under furnace upset conditions.

Moreover, the combustion air system is designed so that the ratio of overfire to underfire air can be varied widely. The placement and amount of overfire air are important in maintaining efficient combustion and critical in maintaining low $\mathrm{CO}$ emissions. The ratio of underfire to overfire air can range from 20:80 to 60:40 depending on the steaming rate, fuel quality, and other variables. It is the overfire air that allows operators to maintain the "three T's" of clean, efficient combustion: time, temperature, and turbulence. 


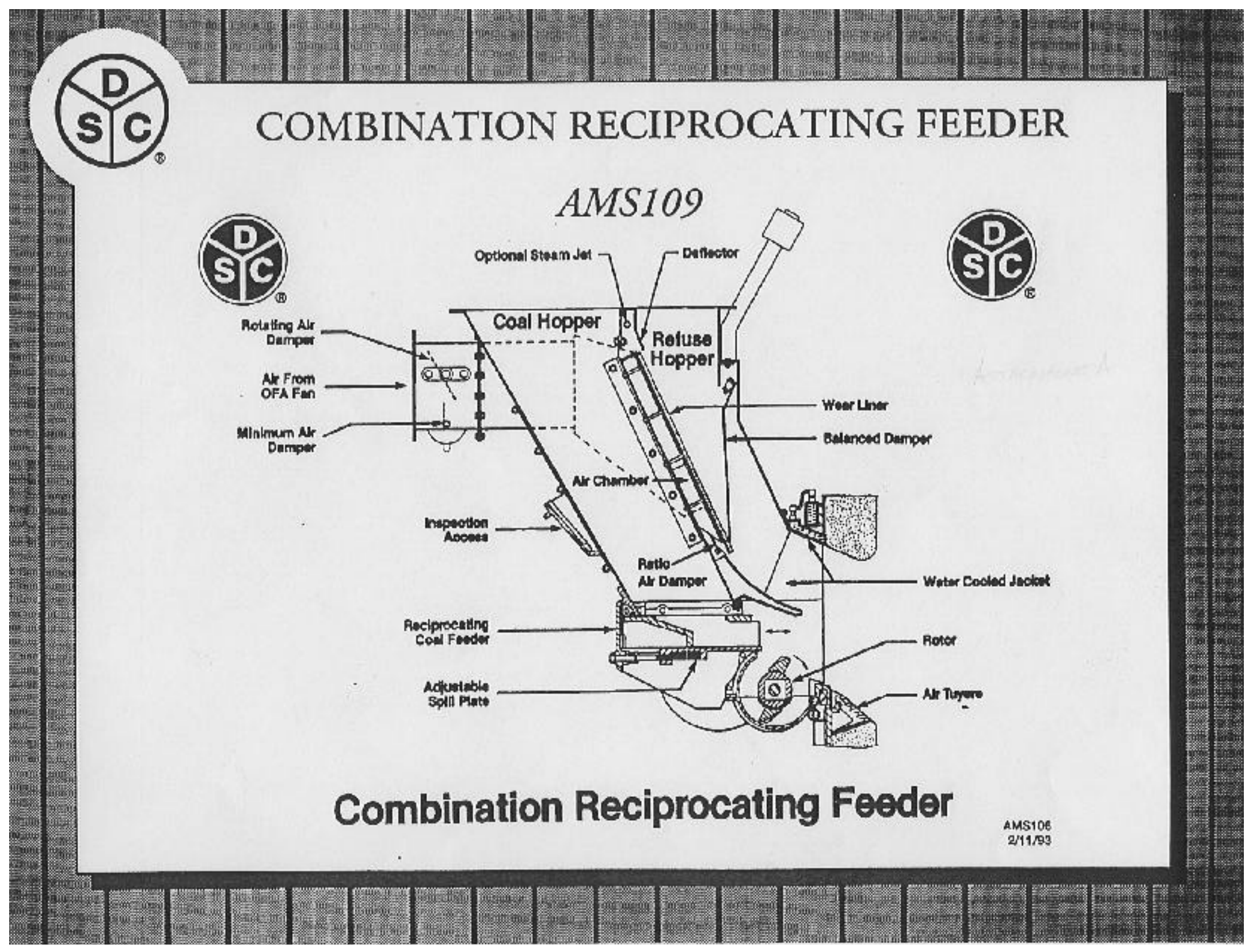




\section{The best of both worlds... in one fuel feeder THE DETROIT COMBINATION FEEDER}

The newly redesigned Detroit Combination Fuel Feeder combines the many features and benefits of Detroit's Air Swept Distributor Spout and the Detroit' Underthrow Fuel Distributor.

The Detroit Air Swept Distributor Spout was designed specifically for Biomass and Refuse fuels. Many industrial processes result in solid waste streams of high calorific value, which is ideally suited for energy recovery. Waste products such as bark, wood waste, sawdust, bagasse, grain hulls, coffee refuse, RDF, and tire chips, have all been burned successfully utilizing Detroit's Air Swept Distributor Spout technology.

The Detroit Underthrow Fuel Distributor is used primarily for coal distribution for spreader stokers. The underthrow design of the rotor coupled with pneumatic assistance is a revolutionary change for fuel distributors. Due to the unique design, operators have been able to reduce their fuel cost by utilizing less expensive, run-ofmine coals which contain a high amount of fines. Due to the high fines and varying moisture content these fuels have traditionally been difficult to distribute evenly and consistently over the fuel bed using

\section{Features \& Benefits:}

! Combination Hopper / Distributor can be retrofitted to existing DSC coal feeders.

! Baffle design in air chamber of spout provides even air distribution across the width of the distributor.

! New combination feeder design provides better fuel distribution by lowering the air outlet point closer to the exit point o the distributor.

! Rugged construction/superior materials stainless steel for areas susceptible to heat. Chromium carbide used at wear points. Factory constructed, assembled and tested.

! Distributes fuel more consistently and evenly than other feeders.

! Improved distribution of fuel promotes less carry-over resulting in lower loss of ignition. conventional coal feeder technology. The Underthrow has been found to be the ideal choice for solving this problem.

In the past it was not uncommon for stoker operators using two different fuels to require separate fuel distributors for each fuel type. With this being the case one distributor would often be mounted higher than the other distributor and the fuel entry points would be at different elevations within the boiler. With one distributor high in the boiler, excessive suspension burning and carry over occurs resulting in less ash cover to protect the grate surface.

The new Detroit Combination Fuel Feeder design allows for both fuels, coal and refuse, to be introduced into the boiler at an elevation that allows the fuels to be spread evenly over the entire stoker grate surface. Fine particles are rapidly burned in suspension while heavier particles are spread evenly burning fuel bed. The combination of suspension burning and fast burning bed improves combustion which can improve furnace efficiency, emissions and makes the stoker extremely responsive to load demand.

! Innovative design makes the Combination Feeder the ideal choice for increasing fuel flexibility.

! Utilizes the smallest furnace opening possible to alleviate damage caused by radiant heat.

! Ideal for distributing fuels inconsistent in size and moisture content. 


\section{ILLUSTRATED FEATURES OF THE COMBINATION FEEDER}

\section{BAFFLED AIR CHAMBER}

in the distributor spout maintains uniform air distribution across the entire width of the distributor.

\section{AIR OUTLET LOCATION}

has been lowered closer to the exit point in the furnace to provide better fuel distribution over the stoker grate surface.

\section{ADJUSTABLE DISTRIBUTOR PLATE}

directs the fuel by the position of an adjustable plate. It can be rotated from the horizontal position up to a 10 degree incline to project fuel to the rear of the stoker.

\section{MOTORIZED ROTARY SL, BIASED AIR DAMPERS}

controls the air to each air swept spout by alternately increasing and decreasing both volume and pressure of the air assuring even fuel distribution within the fin 'nace. The action of these dampers varies the trajectory and spread of the fuel front to rear.

\section{Performance Specification}

No. of Units

Feedrate (modulating 0 to $100 \%$ )

Coal (7000 BTU/LB)

Biomass (5000 BTU/LB)

Motor

\section{CHAIN CONVEYOR CARRIAGE}

meters the fuel feed by varying the speed of the motor from the combustion control system.

\section{CARRIAGE DRIVE AND ROTOR DRIVE}

are separate for each distributor and driven by a $1 \mathrm{HP}$ motor. Each distributor is controlled independently through the use of an A.C. variable frequency drive or through mechanical devices.

\section{DISTRIBUTING UN13ERTHROW ROTOR}

spreads the fuel in the furnace evenly, longitudinally and laterally, over the stoker grate surface.

\section{AIR COOLED APRON TUYERES}

line the bottom of the distributor discharge opening into the furnace to prevent the buildup of fines which could interfere with proper fuel distribution.
$48000 \mathrm{LB} / \mathrm{HR}$

$6720 \mathrm{LB} / \mathrm{HR}$

2 HP 


\section{The Detrolt ${ }^{\circledR}$ Hydrograte $\mathbf{W}$ (1)
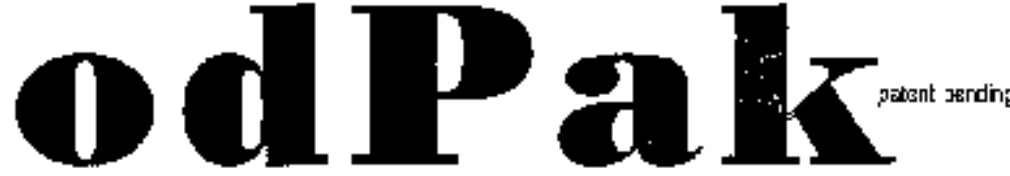

\section{Energy}

\section{From Biomass}

\section{Combustion}

Recyis ing and redsction cf our world's waste stream is not only environmentally necessary, it also rJakes çood busincss scnse. Man'y Indu strla processes poduce sclic wastes of igh reating value iceally suited for e eergy recovery. Whith tocay's high cost of conten:ioral fuels, extraction c: ușeful energy from ot

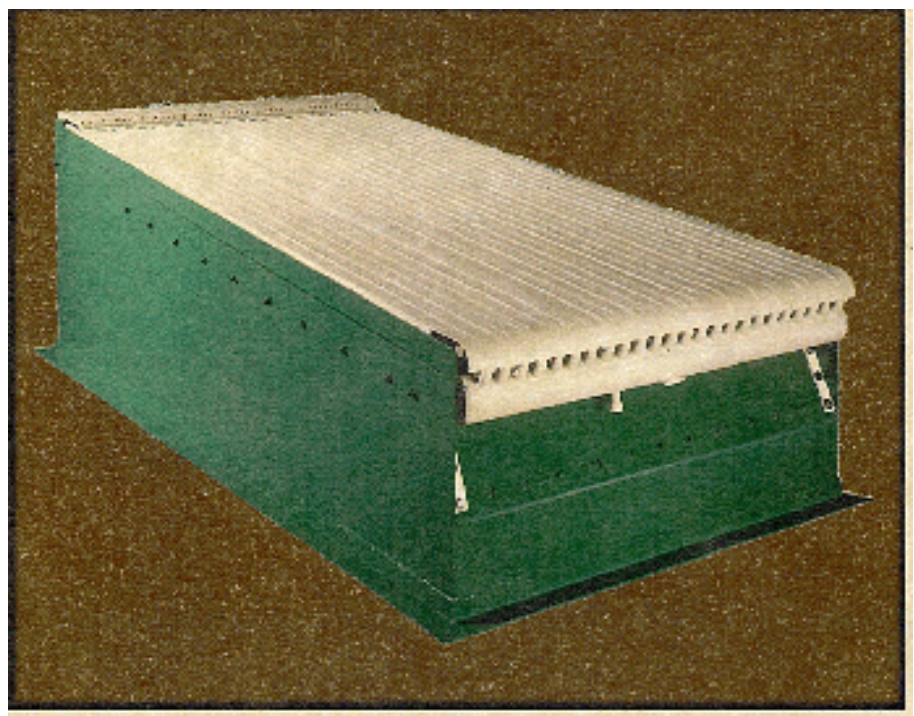
wise non-recyclakle materials sep esen.s recycing at iis finesl.

The Debroit Hydrograte WoodPak is designed far the forestry and irood working industries, to provide a long term answer for bionass utilization and ervi:onmental esponsib:. ty. The WuodPak is suiluble [or a wide varioly of biomass fuels conlaining up to $60 \%$ moislure.

\section{Renewable Fuels -}

\section{Today's Environmental}

\section{choice}

Biomass fuels $a^{*} e$ considered $\mathrm{CO}_{2}$. neutrel becelusc the carbon dioxise erristed dur ng comtustion is used in the growth cyole oi renewable fuei sources. This process nakes biomass the world's largest rereuratle supsly of energy. Futhermore, biomass fuels produce insigr, fican: emission igvels when compered to the fossil fuels they replace.

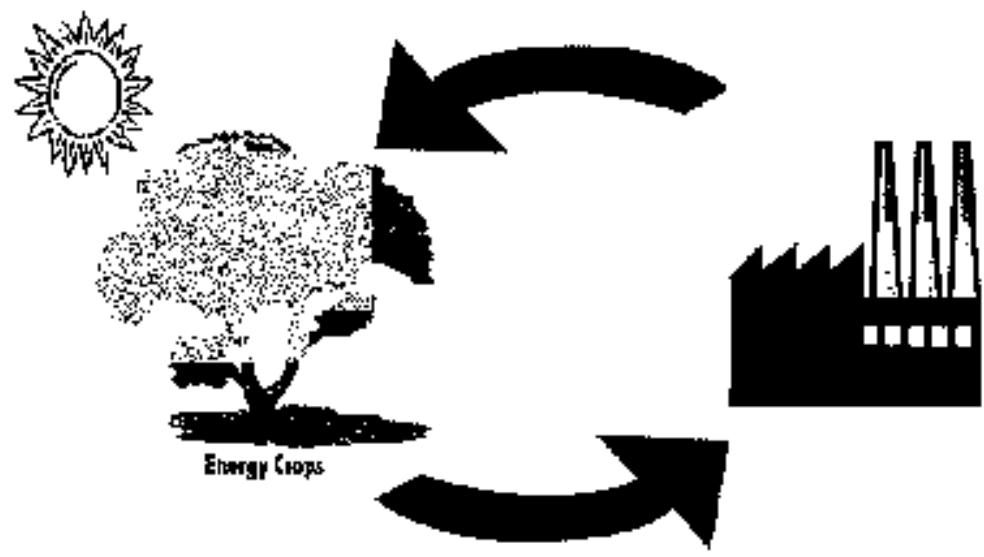

$\mathrm{CO}_{2}$-reutfal, biomass combetustion does nof contnblite to the bififoid of greeri houla gasses. 
line Cerroit WisocPak systeris unirue tes grn fatures solvo. many of the comoustion crosiers associatec with biar ass ji:srinz

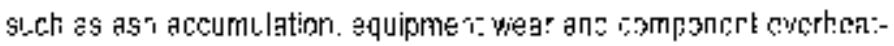

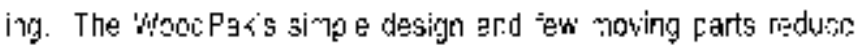

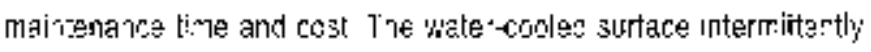
vibrares ror antomatic azh bischarge and jermits csntin wous operation withou: shutdours io clean çrates. I?ecause tre stoker is water.

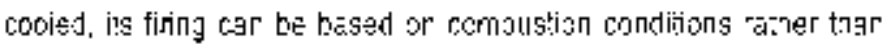
coolirç air requirements. "ris makes it poss ble. to maint?in highticr cortusjor air temperatures nerassary ior berring hig. -7cisturn, low ash jionass fuels whout damage to the gratc surince.

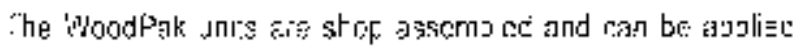
10 nosi tyces of sieam holers hot wats tri rers, hagt exchringers:

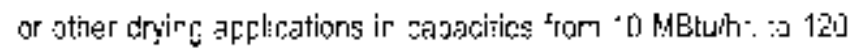

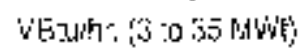

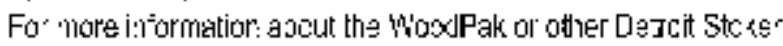

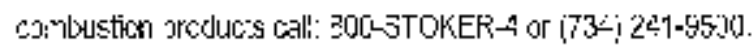

\section{Benefits}

- ideal For Higy Molstureílow Ash Fuels

- Higher EfFieienCi

- Loner Emissichs

- Requcej Maintevance Costs

- Higher avalianulty

- Automatr Ash Discharge

- Fen' Mouing Parts

- No Luerication Probleys

- Minimizes Undergrate Air

- Reduged Instaliat ch T me

\section{Woodpak}

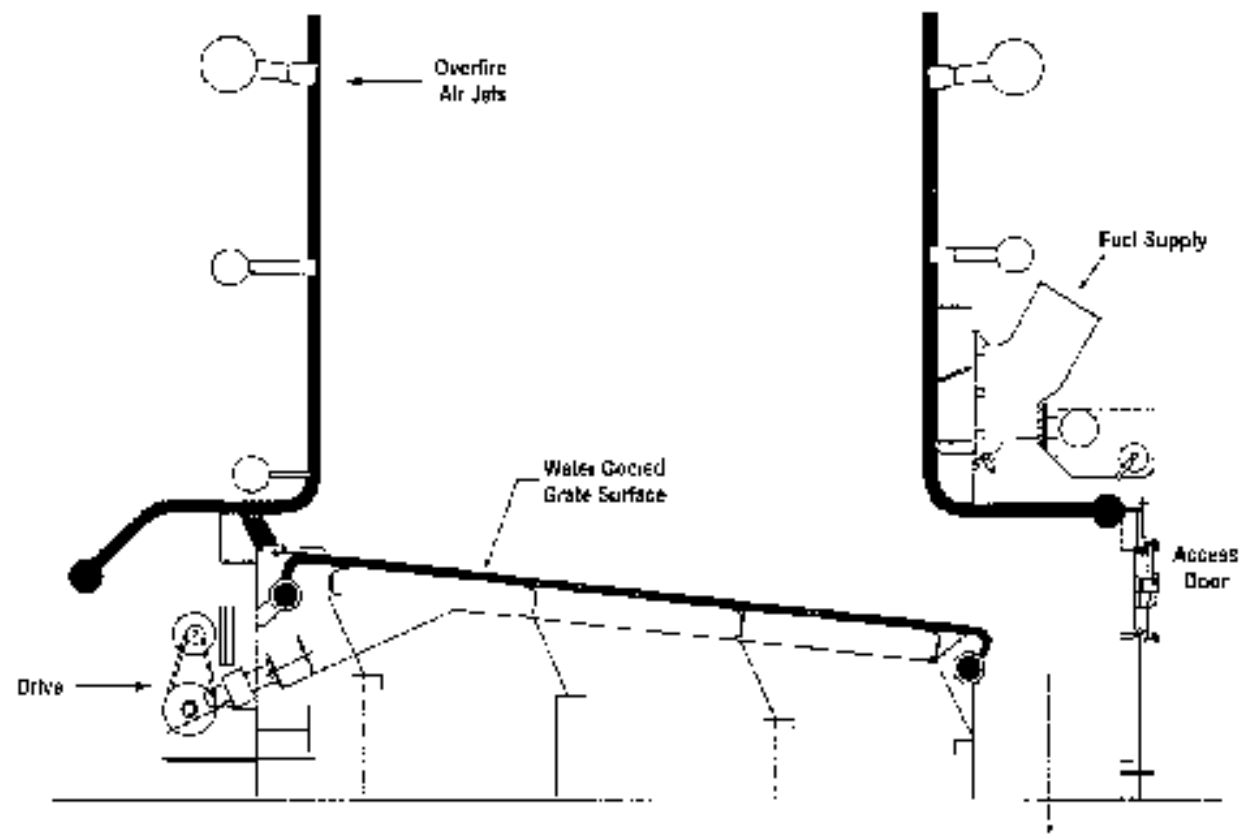

\section{Specification}

Feedrate (modulating 0 to $100 \%$ )

Coal (7000 BTU/LB)

Biomass (5000 BTU/LB)

Grate Area =

$48000 \mathrm{LB} / \mathrm{HR}$

Dimensions =

Motor

6720 LB/HR

160 SQ. FT.

7.5 Ft. Wide x 24 Ft. Long

$10 \mathrm{HP}$ 


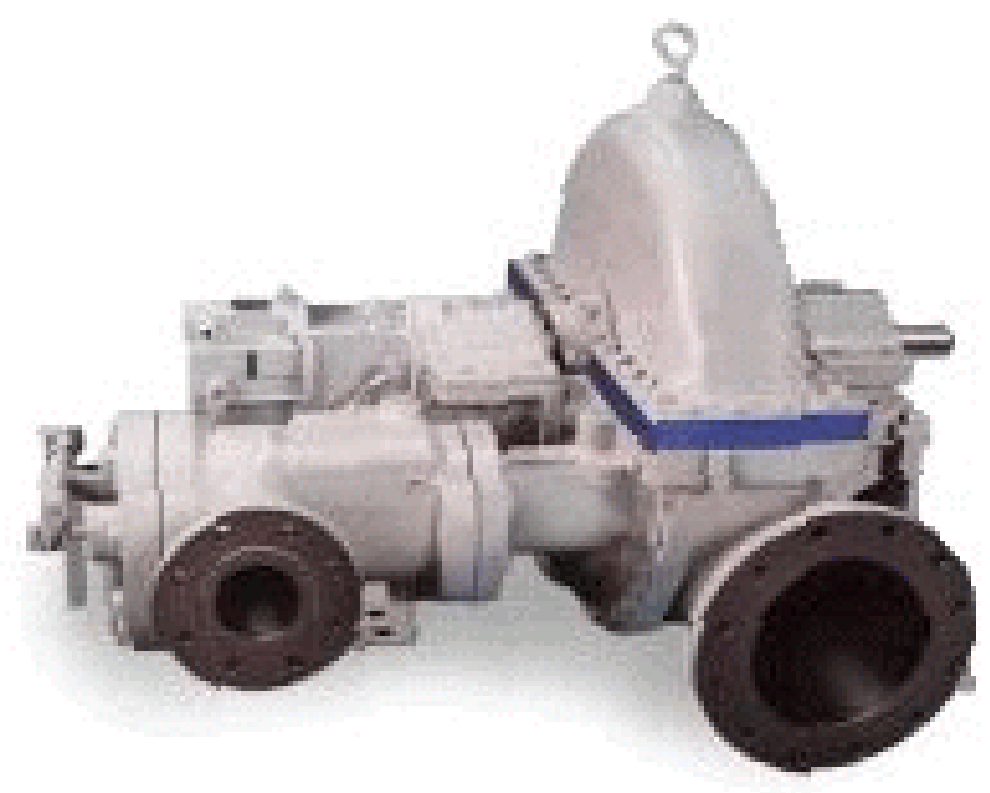

\section{RLHA/RLHB Horizontal Single Stage Turbines}

Engineered for higher efficiencies and in place maintenance. RLHA turbines are available in four frame sizes offering a horsepower range of 10 to over 4,000 (7.5 to 2984+ kW). This series is designed for higher efficiencies, operating conditions and steam flows than those accommodated by the RLA. The RLHA's design meets the standards of API611.

Common applications: process pumps, compressors and fans; cogeneration markets.

\section{Features:}

- Axially split construction.

- Choice of sleeve or antifriction journal bearings.

- Pedestal centerline support.

- Balanced, cage-guided governor valve.

- Positive-seating trip valve.

\section{Benefits:}

- Allows fast, easy, in place maintenance

- Allows customer a choice based on lubrication preference.

- Isolates bearing housings from forces due to pipe stress and minimum thermal movements.

- Minimizes actuating force and optimizes control. 
DRESSER RAND

BOX 19188

HOUSTON, TEXAS 77224-9188

PHONE (713) 973-5368 FAX (713) 935-3490

TO: KJ C SCHWARTZ ENG.

DATE: MARCH 10, 2001

233 WEST ROSSER AVE.

BISMARK,N.D. 58501

ATT: KEN SCHWARTZ

FAX: (701) 222-3770

FROM: FOSTER KNEELAND

SUBJ : DEPT. OF CORRECTIONS

BISMARK, ND.

KEN;

THANK YOU FOR YOUR PHONE CALL OF TODAY'S DATE AND YOUR INTEREST IN DRESSER-RAND. AS REQUESTED, WE ARE PROVIDING AN ESTIMATE ON A TURBINE GENERATOR SET AS SHOWN BELOW:

GIVEN: $\quad 20,000$ \#HR OF 200-SAT-15 STEAM

MODEL: $\quad$ 703E STEAM TURBINE

PERFORMANCE: $\quad 410 \mathrm{KW}$ AT THE GENERATOR LEADS

PRICE: $\quad \$ 100-110,000$ FOB WELLSVILLE NY DEPENDENT ON FINAL SPECIFICATIONS

SHIPMENT: $\quad$ 22-24 WEEKS AFTER RECEIPT OF ORDER WITH FULL RELEASE

ENVELOPE DIMENSIONS: $\quad 16^{\prime} \mathrm{L} \times 6^{\prime} \mathrm{W} \times 6^{\prime} \mathrm{H}$

SCOPE OF SUPPLY: TURBINE, GEAR REDUCER, 480V GENERATOR, BASEPLATE, ELECTRONIC GOVERNOR

EXCLUDED FROM SCOPE: GENERATOR CONTROLS, OR ANY ITEM UPSTREAM I DOWNSTREAM OF TURBINE FLANGES SUCH AS EXPANSION J OINTS, SHUT-OFF VALVES, RELIEF VALVES, ETC.

UNDER SERERATE COVER AND IN TODAY'S MAIL IS SOME DESCRIPTIVE LITERATURE AND MY BUSINESS CARD.

THANK YOU AGAIN FOR YOUR INTEREST. 
P.O. Box 19188

Phone: 713-973-5368

Fax: $713-935-3490$

August 24, 2001

K.J. Schwartz Eng.

233 West Rosser Ave.

Bismark, ND 58501

Attention: Ken Schwartz

Fax: (701) 222-3770

Subject: Department Of Corrections

Bismark, ND

Ken:

Thank you for your phone call of today's date and your interest in Dresser-Rand. As requested, we are providing as estimate on a Turbine Generator Bet as shown below:

Given: $\quad 25,000 \#$ I Hr of 200-SAT-10" HGA Steam

Model: $\quad$ 703LPE Steam Turbine

Performance: $800 \mathrm{KW}$ at the generator leads

Price: $\quad \$ 175,000-\$ 200,000$ FOB Wellsville, NY dependent on final specifications.

Shipment: $\quad 22-24$ weeks after receipt of order with full release

Envelope Dimensions: $\quad 18^{\prime} \mathrm{L} X 6^{\prime} \mathrm{VV} X \mathrm{i} 3^{\prime} \mathrm{H}^{\prime}$

Scope Of Supply: Turbine, Gear Reducer, 480V Generator, Baseplate te, Electronic Governor, Condenser

Excluded From Scope: Generator Controls, or any item Upstream/Downstream of Turbine Flanges such as expansion joints, shut-off valves, relief valves, etc.

In the event you have further questions, you may contact our local representative -- Power Process Co. in Chanhassen, Minnesota; Jim Myers (952) 975-5662.

Thank you again for your interest.

Cordially,

DRESSER-RAND COMPANY The Americas

Foster Kneeland Account. Mgr.

FAK:mc

cc Wellsville-U.Covell Power Process-J.Myers 
B-6. Equipment Budget 


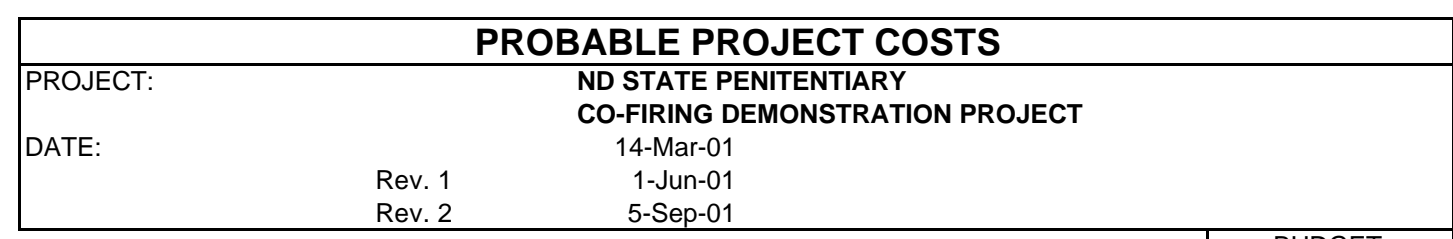

1 New Vibrating Grate Stoker to replace existing Dump Grate

A Existing Equipment removal and new Equipment installation

B Raise Boiler $3 \mathrm{ft}$. for new stoker installation including piping modifications and support structure

2 Fuel Conditioning/Preparation Grinder \& Screening with Conveyors

A Installation

B Electrical

3 Biomass Fuel Handling Systems
Conveyors
$400 \mathrm{LF} \quad \$ 155.00$ Per LF

Installation \& Supports

$4 \quad$ Existing Coal Fuel Handling System Modifications

5 Fuel Metering Systems - Coal \& Wood - (PLC) Installation

$6 \quad$ Ash Handling System Modifications

7 Condensate Storage Tank \& Pumps Installation

8 Steam Turbine/Generators \& Switchgear

1 Recond

1 Recond

600 KW Cond.

$450 \mathrm{KW} \mathrm{BP}$

$1050 \mathrm{KW}$ Total

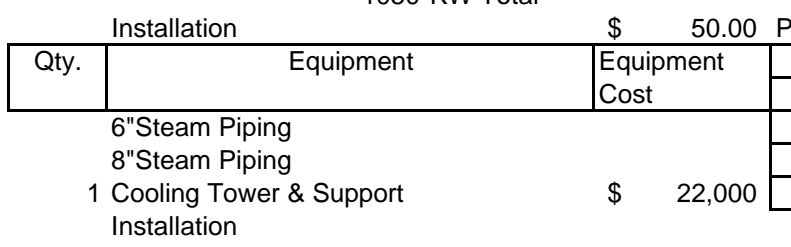

1 Heat Exchanger

1 Condenser Water Pump

$\$ 3,600.00$

Installation

Misc. Piping: Air Compressor, water, Fittings, Valves

Automatic Controls Systems

Electrical

9 General Construction

A. Fuel Process Building

Foundation \& Concrete

Sitework

Electrical

B. Existing Building Modifications

Misc. Patch \& Paint

Steel

Concrete

C. Biomass Fuel Drying Bunker Building

G-M-E 28' x 20' x 20'

D. Turbine Generator Building

G-M-E 28' x 26' x 16' $\times 2$

11200 C.F.

\$ 4.50 Per C.F.

$\$ \quad 7.00$ Per S.F.

8000 S.F.

\$ 11.00 Per C.Y.

4400 C.Y.

\begin{tabular}{|lr|}
\hline$\$$ & 300,000 \\
\hline$\$$ & 60,000 \\
\hline$\$$ & \\
\hline$\$$ & 270,000 \\
\hline$\$$ & 20,000 \\
\hline$\$$ & 12,000 \\
\hline
\end{tabular}

$\$ \quad 62,000$

$\$ \quad 16,000$

\begin{tabular}{ll}
$\$$ & 5,000 \\
\hline & 7,000 \\
\hline
\end{tabular}

\begin{tabular}{ll}
$\$$ & 7,000 \\
\hline$\$$ & 6,000 \\
\hline
\end{tabular}

$\$ \quad 8,000$

$\$ \quad 8,000$

$\$ 2,000$

$\$ \quad 50,000$

$\$ \quad 50,000$

$\$ \quad 52,500$

\begin{tabular}{r|rr|lr|}
\multicolumn{3}{|c|}{ Piping } & & \\
\hline Lin. Ft. & \multicolumn{2}{|c|}{ Cost/ft } & & \\
\hline 60 & $\$$ & 30.00 & $\$$ & 1,800 \\
\hline 85 & $\$$ & 40.00 & $\$$ & 3,400 \\
\hline 120 & $\$$ & 38.00 & $\$$ & 26,560 \\
\hline & & & $\$$ & 12,000 \\
\cline { 3 - 4 }
\end{tabular}

iomass Fuel Drying System

10

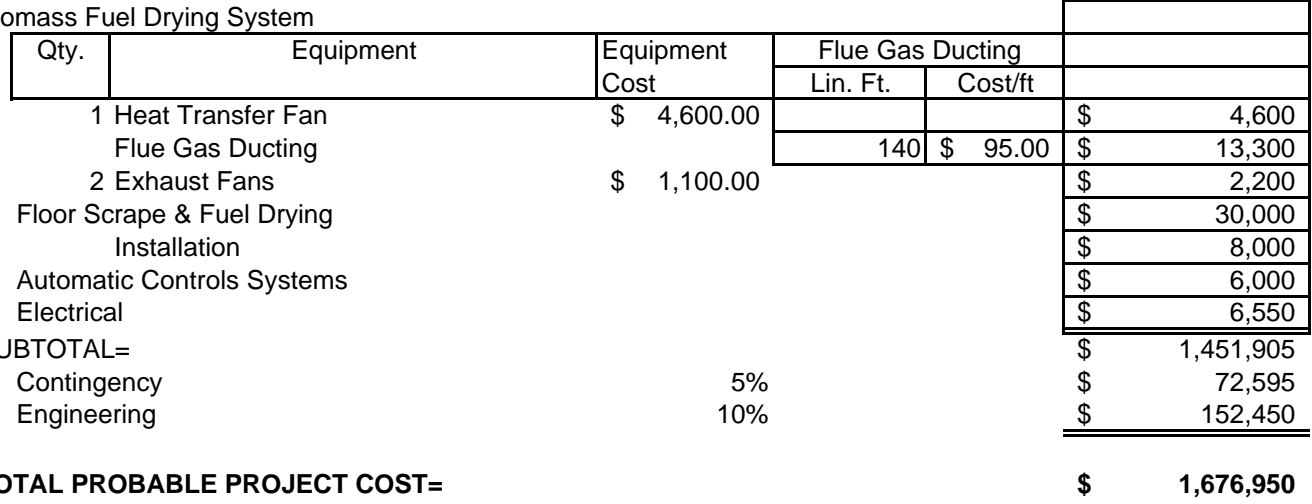


APPENDIX C

\section{FIRESIDE DATA}


FIRESIDE DATA

C-1. Description of PCQUEST Model 


\section{PCQUEST Modeling}

\section{PCQUEST Input}

The PCQUEST (Predictive Coal Quality Effects Screening Tool) model input requires a standard American Society for Testing and Materials as-received proximate analysis (\% moisture, volatile matter, fixed carbon, and ash), as-received ultimate analysis (\% hydrogen, carbon, nitrogen, sulfur, oxygen, and ash), and bulk ash chemistry ( $\% \mathrm{SiO}_{2}, \mathrm{Al}_{2} \mathrm{O}_{3}, \mathrm{Fe}_{2} \mathrm{O}_{3}, \mathrm{TiO}_{2}$, $\mathrm{P}_{2} \mathrm{O}_{5}, \mathrm{CaO}, \mathrm{MgO}, \mathrm{Na}_{2} \mathrm{O}, \mathrm{K}_{2} \mathrm{O}$, and $\mathrm{SO}_{3}$ ). The FACT (Facility for the Analysis of Chemical Thermodynamics) model requires only the as-received ultimate and bulk ash chemistry analyses.

The PCQUEST calculations also require computer-controlled scanning electron microscopy (CCSEM) analysis, image analysis (IMA), and chemical fractionation (CHF) analysis as well as proximate, ultimate, and bulk ash chemistry analysis of the coal. IMA is automatically performed as part of the CCSEM analysis.

The CCSEM analysis is used to determine the size and composition of the mineral grains in a fuel that are greater than $1 \mu \mathrm{m}$ in diameter, along with IMA analysis to determine the association of the mineral grains, i.e., whether mineral grains are embedded in the coal particles (included minerals) or are free grains not attached to the coal particles (excluded minerals). This association of mineral grains has a significant effect on the formation of fly ash and ash deposits, with included mineral grains much more likely to combine with each other than the free excluded mineral grains.

The CHF analysis is a series of selective chemical leachings that quantifies organically bound inorganics and minerals that are less than $1 \mu \mathrm{m}$ in size. Organically bound inorganics are found only in low-rank fuels and comprise the bulk of the inorganics that are less than $1 \mu \mathrm{m}$ in size. Low-rank subbituminous and lignite coals act as ion-exchange materials, with alkali and alkaline-earth elements such as $\mathrm{Ca}^{++}, \mathrm{Na}^{+}$, and $\mathrm{K}^{+}$attaching to carboxylic acid groups in the coal. Up to half the calcium and all of the sodium and potassium present in the coal ash may be bound in this way. When the coal is burned, these highly dispersed elements have a high propensity to interact with other minerals present as well as form very fine ash.

\section{PCQUEST Output}

Eight indices are calculated: grindability, high-temperature fouling, low-temperature fouling, slagging, slag tapping, sootblowing, erosion, and opacity, either for a specific power station using the input boiler parameters or for a generic boiler.

The predicted grindability corresponds to the Hardgrove grindability and was developed for western subbituminous coals. Grindability of western coals is especially susceptible to moisture, and the predicted values may not reflect actual determined grindabilities well. The grindability index is best used as an indication of relative changes in grindability rather than as actual Hardgrove values. The high-temperature fouling index is a measure of fouling occurring at the front part of the convective pass in the secondary superheater and reheater region. Such fouling is primarily silicate based and is strongly dependent on the furnace exit gas temperature (FEGT). 
The low-temperature fouling index is a measure of fouling occurring in the primary superheater and economizer region of the convective pass. Such deposition is primarily calcium-based, forming smooth, very hard calcium sulfate deposits. The sootblowing index is related to the hightemperature fouling index and is an indication of the ease of removal of the high-temperature deposits. The slagging index is a measure of slagging propensity on walls in the radiant section of the boiler. Depending on the FEGT, the slagging region may extend to include platen superheater and reheater surfaces suspended over the furnace box and surfaces at the entrance to the convective pass. The slag-tapping index gives an estimation of the ease of slag flow from the cyclone barrels of a cyclone-fired boiler. The tube erosion index provides a relative indication of the ash abrasiveness based on the ash hardness and kinetic energy, which is dependent on the gas velocity selected as input in the boiler parameters. This index value reflects the abundance of large, hard quartz and pyrite mineral particles in the coals, but has not been calibrated against actual field observations of erosion. The opacity index provides an indication of the difficulty of ash collectibility, based on the relative abundance of fine hard-to-collect minerals and organically bound minerals in the coal. This value is indicative only of the difficulty of collecting fine ash, in this case reflecting the resistivity of the ash. A well-functioning collection device may effectively control even apparently fine particulate emissions.

The indices, except for the grindability index, are on a scale of $0-100$, with $0-33$ being low, 34-66 being medium, and 67-100 being a high or severe value. The resolution of the calculations is such that differences of 2-3 index units indicate effectively the same performance. PCQUEST is best used to evaluate the relative performance of coals and is most effective if a coal with known fireside performance is included as a "benchmark."

\section{Boiler Inputs}

In addition to fuel analyses, the model requires some rudimentary boiler information. The boiler inputs are as follows:

Flue gas velocity $(\mathrm{m} / \mathrm{s}$, convective pass): $\quad \underline{1.6}$

Particulate collection device, indicate one of the following:

Baghouse

Cold-side electrostatic precipitator (ESP) Hot-side ESP $\_$, av. operating temp. $\underline{208 E C}$ , av. operating temp. $\mathrm{EC}$

Scrubber

Furnace box cross-sectional area $\left(\mathrm{ft}^{2}\right) \quad 89$

Design maximum continuous rating firing rate $(\mathrm{lb} / \mathrm{hr})$

Design coal heating value $(\mathrm{Btu} / \mathrm{lb}) \quad 7240$

Design coal ash content ( $\%$ of coal) 6.28

Burner design, pick one of the following:

Conventional burners $\mathrm{X}$

Low-NO $\mathrm{N}_{\mathrm{x}}$ burners

pc-fired or cyclone-fired $\mathrm{X}$ 
C-2. Description of FACT Code 


\section{FACT Modeling}

FACT (Facility for the Analysis of Chemical Thermodynamics) is an integrated thermodynamic database coupled to programs developed to calculate multicomponent multiphase equilibria based on a minimization of Gibbs' free energy. Once the initial system composition and pressure are set, FACT determines equilibrium concentrations of solid, liquid, and gas species over a specified temperature range. It should be noted that FACT calculates equilibrium concentrations independently at each temperature. Depending on the kinetics of the reactions occurring, these equilibrium concentrations may or may not be achieved. FACT is also constrained by the number of elements selected as input and by the compounds available and selected to be considered in the calculations from the thermodynamic database. The sample analyses used in the FACT calculations consisted of the bulk ash chemistry analyses and asreceived ultimate analysis. FACT may also be used on blends, with the input being a calculated blend ultimate and ash chemistry analysis. Because the FACT calculations and postprocessing of the results are quite labor-intensive, only a limited number of blend scenarios are performed.

FACT determines the equilibrium amounts of gas, liquid, and solid compounds as a function of temperature. Calculations are normally performed at $45 \mathrm{EF}(25 \mathrm{EC})$ intervals from $932 \mathrm{E}-2732 \mathrm{EF}(500 \mathrm{E}-1500 \mathrm{EC})$. Note that the calculation at each temperature is independent of the previous or subsequent calculations and that each calculation represents an equilibrium condition which may not be kinetically or physically achieved. The compounds considered are approximately 30 or more major and minor gas species of highest concentration (FACT needs about this many gas species to allow the matrices to converge), a silicate-based liquid slag, and a solid calcium-magnesium sulfate solution which is indicative of potential low-temperature calcium-based fouling, and all pure solid species in the FACT database.

Calculations are performed on a weight basis to determine the percentage of liquid phases present as a function of temperature. A second calculation is performed on a mole basis to provide input for viscosity calculations. Viscosities for the liquid-phase material as a function of temperature are subsequently calculated using a modified form of the Urbain equation in a spreadsheet for each sample.

Both the viscosity and the amount of liquid phases present are important in predicting the amount of slagging and fouling which can occur. For example, at a given temperature, a coal with a higher percentage of liquid phases with lower viscosity would be expected to show more severe fouling behavior relative to a baseline coal. Although these calculated rates may not accurately reflect the actual magnitude of deposition experienced in a full-scale boiler, they give an indication of the relative fouling behavior.

The PCQUEST and FACT models complement each other, together providing a reasonable prediction of relative fireside performance. The advantage of PCQUEST is that ash partitioning between bottom ash and fly ash is accounted for in the model algorithms, while FACT uses the bulk coal ash composition. However, FACT provides predictions as a function of temperature, while the PCQUEST model implicitly assumes a "typical" boiler with an FEGT of approximately $2200 \mathrm{EF}$. 


\section{C-3. Lignite CCSEM Mineral Distribution}


State Penitentiary

DMC 08/09/01

Table C-3. Lignite CCSEM Mineral Distribution, wt\%

Mineral Fraction: $\quad 5.889$

Size Bins:

$1.0-2.2 \quad 2.2-4.6 \quad 4.6-10$

$10-22$

$22-46 \quad 46-100$

Total \% Excluded

\begin{tabular}{|c|c|c|c|c|c|c|c|c|}
\hline Quartz & 1.8 & 2.4 & 2.9 & 2.4 & 1.3 & 0.1 & 10.9 & 64.4 \\
\hline Iron Oxide & 0.1 & 0.2 & 0.1 & 0.0 & 0.0 & 1.1 & 1.4 & 96.2 \\
\hline Periclase & 0.0 & 0.0 & 0.0 & 0.0 & 0.0 & 0.0 & 0.0 & 0.0 \\
\hline Rutile & 0.0 & 0.0 & 0.0 & 0.0 & 0.0 & 0.0 & 0.0 & 100.0 \\
\hline Alumina & 0.0 & 0.0 & 0.0 & 0.1 & 0.0 & 0.0 & 0.1 & 0.0 \\
\hline Calcite & 0.0 & 0.0 & 0.0 & 0.1 & 0.2 & 0.0 & 0.3 & 100.0 \\
\hline Dolomite & 0.0 & 0.1 & 0.1 & 0.0 & 0.1 & 0.0 & 0.3 & 100.0 \\
\hline Ankerite & 0.0 & 0.0 & 0.0 & 0.0 & 0.0 & 0.0 & 0.0 & 0.0 \\
\hline Kaolinite & 0.8 & 1.8 & 1.8 & 1.3 & 0.8 & 1.3 & 7.9 & 48.2 \\
\hline Montmorillonite & 0.3 & 0.7 & 0.2 & 0.1 & 0.0 & 0.0 & 1.3 & 31.0 \\
\hline K Al-Silicate & 1.1 & 1.7 & 0.9 & 0.3 & 0.5 & 2.2 & 6.6 & 81.3 \\
\hline Fe AI-Silicate & 1.2 & 1.2 & 0.4 & 0.2 & 0.2 & 0.3 & 3.5 & 61.5 \\
\hline Ca Al-Silicate & 0.4 & 0.1 & 0.2 & 0.3 & 0.1 & 0.1 & 1.2 & 38.1 \\
\hline Na Al-Silicate & 0.0 & 0.0 & 0.0 & 0.0 & 0.0 & 0.0 & 0.0 & 0.0 \\
\hline Aluminosilicate & 0.0 & 0.0 & 0.1 & 0.1 & 0.1 & 0.0 & 0.3 & 73.0 \\
\hline Mixed Aluminosilicate & 1.2 & 2.1 & 0.7 & 1.3 & 0.8 & 1.7 & 7.7 & 73.9 \\
\hline Fe Silicate & 0.0 & 0.0 & 0.0 & 0.0 & 0.0 & 0.0 & 0.0 & 0.0 \\
\hline Ca Silicate & 0.0 & 0.0 & 0.0 & 0.0 & 0.0 & 0.0 & 0.1 & 18.6 \\
\hline Ca Al-Silicate & 0.0 & 0.0 & 0.0 & 0.0 & 0.0 & 0.0 & 0.0 & 0.0 \\
\hline Pyrite & 0.0 & 0.2 & 0.4 & 0.4 & 1.1 & 0.1 & 2.2 & 93.3 \\
\hline Pyrrhotite & 1.4 & 4.1 & 6.0 & 10.0 & 8.3 & 5.7 & 35.4 & 91.8 \\
\hline Oxidized Pyrrhotite & 0.1 & 0.1 & 0.2 & 0.5 & 0.1 & 0.0 & 1.0 & 96.5 \\
\hline Gypsum & 0.1 & 0.2 & 0.1 & 0.0 & 0.0 & 0.0 & 0.4 & 28.3 \\
\hline Barite & 0.1 & 0.1 & 0.3 & 0.4 & 0.2 & 0.0 & 1.1 & 100.0 \\
\hline Apatite & 0.1 & 0.0 & 0.1 & 0.2 & 0.0 & 0.0 & 0.4 & 84.1 \\
\hline Ca Al-Phosphate & 0.0 & 0.0 & 0.0 & 0.0 & 0.0 & 0.0 & 0.0 & 0.0 \\
\hline $\mathrm{KCl}$ & 0.0 & 0.0 & 0.0 & 0.0 & 0.0 & 0.0 & 0.0 & 0.0 \\
\hline Gypsum/Barite & 0.0 & 0.0 & 0.0 & 0.0 & 0.0 & 0.0 & 0.0 & 0.0 \\
\hline Gypsum/Aluminosilicate & 0.2 & 0.0 & 0.0 & 0.1 & 0.1 & 0.1 & 0.4 & 45.7 \\
\hline Silica-Rich & 0.4 & 0.5 & 0.5 & 0.5 & 0.4 & 0.8 & 3.1 & 71.6 \\
\hline Ca-Rich & 0.0 & 0.0 & 0.0 & 0.0 & 0.0 & 0.0 & 0.0 & 0.0 \\
\hline Ca-Si-Rich & 0.0 & 0.0 & 0.0 & 0.0 & 0.0 & 0.0 & 0.0 & 0.0 \\
\hline Unknown & 4.0 & 3.7 & 1.8 & 0.3 & 1.5 & 3.1 & 14.4 & 67.3 \\
\hline Totals & 13.5 & 19.2 & 16.7 & 18.6 & 15.6 & 16.4 & 100.0 & \\
\hline
\end{tabular}




\section{C-4. Lignite CCSEM \% of Excluded Minerals}


DMC 08/09/01

Table C-4. Lignite CCSEM Percentage of Excluded Minerals, wt\%

\begin{tabular}{lrrrrrr} 
Size Bins: & $1.0-2.2$ & $2.2-4.6$ & $4.6-10$ & $10-22$ & $22-46$ & $46-100$ \\
\hline & & & & & & \\
Quartz & 39.3 & 69.3 & 71.4 & 67.9 & 65.1 & 100.0 \\
Iron Oxide & 27.3 & 100.0 & 100.0 & 0.0 & 0.0 & 100.0 \\
Periclase & 0.0 & 0.0 & 0.0 & 0.0 & 0.0 & 0.0 \\
Rutile & 0.0 & 0.0 & 100.0 & 0.0 & 0.0 & 0.0 \\
Alumina & 0.0 & 0.0 & 0.0 & 0.0 & 0.0 & 0.0 \\
Calcite & 0.0 & 0.0 & 100.0 & 100.0 & 100.0 & 0.0 \\
Dolomite & 0.0 & 100.0 & 100.0 & 0.0 & 100.0 & 0.0 \\
Ankerite & 0.0 & 0.0 & 0.0 & 0.0 & 0.0 & 0.0 \\
Kaolinite & 21.4 & 33.3 & 53.0 & 42.7 & 52.0 & 81.8 \\
Montmorillonite & 29.3 & 15.1 & 56.5 & 100.0 & 48.2 & 0.0 \\
K Al-Silicate & 43.9 & 69.8 & 91.2 & 100.0 & 97.6 & 100.0 \\
Fe Al-Silicate & 31.9 & 62.6 & 78.2 & 100.0 & 100.0 & 100.0 \\
Ca Al-Silicate & 0.0 & 0.0 & 25.1 & 100.0 & 12.7 & 100.0 \\
Na Al-Silicate & 0.0 & 0.0 & 0.0 & 0.0 & 0.0 & 0.0 \\
Aluminosilicate & 0.0 & 0.0 & 54.2 & 100.0 & 78.0 & 0.0 \\
Mixed Aluminosilicate & 33.0 & 47.9 & 94.6 & 100.0 & 89.5 & 100.0 \\
Fe Silicate & 0.0 & 0.0 & 0.0 & 0.0 & 0.0 & 0.0 \\
Ca Silicate & 0.0 & 0.0 & 50.9 & 0.0 & 0.0 & 0.0 \\
Ca Al-Silicate & 0.0 & 0.0 & 0.0 & 0.0 & 0.0 & 0.0 \\
Pyrite & 100.0 & 100.0 & 100.0 & 100.0 & 85.9 & 100.0 \\
Pyrrhotite & 74.1 & 69.4 & 93.1 & 94.1 & 96.1 & 100.0 \\
Oxidized Pyrrhotite & 60.8 & 100.0 & 100.0 & 100.0 & 100.0 & 0.0 \\
Gypsum & 31.6 & 0.0 & 75.3 & 0.0 & 0.0 & 0.0 \\
Barite & 100.0 & 100.0 & 100.0 & 100.0 & 100.0 & 0.0 \\
Apatite & 65.6 & 0.0 & 100.0 & 100.0 & 0.0 & 0.0 \\
Ca Al-Phosphate & 0.0 & 0.0 & 0.0 & 0.0 & 0.0 & 0.0 \\
KCl & 0.0 & 0.0 & 0.0 & 0.0 & 0.0 & 0.0 \\
Gypsum/Barite & 0.0 & 0.0 & 0.0 & 0.0 & 0.0 & 0.0 \\
Gypsum/Aluminosilicate & 14.8 & 0.0 & 0.0 & 100.0 & 55.4 & 100.0 \\
Silica-Rich & 38.2 & 14.8 & 74.3 & 100.0 & 92.1 & 100.0 \\
Ca-Rich & 0.0 & 0.0 & 0.0 & 0.0 & 0.0 & 0.0 \\
Ca-Si-Rich & 0.0 & 0.0 & 0.0 & 0.0 & 0.0 & 0.0 \\
Unknown & 31.9 & 58.8 & 87.6 & 100.0 & 88.3 & 98.4 \\
\hline & & & & & &
\end{tabular}


C-5. Tree Wood CCSEM Mineral Distribution 
State Penitentiary

DMC 08/09/01

Table C-5. Tree Wood CCSEM Mineral Distribution, wt\%

Mineral Fraction: $\quad 2.534$

Size Bins:

$1.0-2.2 \quad 2.2-4.6 \quad 4.6-10$

$10-22$

$22-46 \quad 46-100$

Total \% Excluded

\begin{tabular}{|c|c|c|c|c|c|c|c|c|}
\hline Quartz & 0.5 & 2.0 & 1.1 & 0.2 & 0.7 & 2.9 & 7.3 & NA \\
\hline Iron Oxide & 0.5 & 1.5 & 0.6 & 1.6 & 0.1 & 0.0 & 4.2 & NA \\
\hline Periclase & 0.0 & 0.0 & 0.0 & 0.0 & 0.0 & 0.0 & 0.0 & NA \\
\hline Rutile & 0.0 & 0.4 & 0.2 & 0.0 & 0.0 & 0.0 & 0.6 & NA \\
\hline Alumina & 0.0 & 0.0 & 0.0 & 0.0 & 0.0 & 0.0 & 0.0 & NA \\
\hline Calcite & 4.0 & 6.8 & 7.0 & 7.9 & 1.7 & 0.0 & 27.5 & NA \\
\hline Dolomite & 0.5 & 0.7 & 0.7 & 1.0 & 0.7 & 1.4 & 5.0 & NA \\
\hline Ankerite & 0.0 & 0.0 & 0.0 & 0.0 & 0.0 & 0.0 & 0.0 & NA \\
\hline Kaolinite & 0.1 & 0.0 & 0.0 & 0.0 & 0.0 & 0.0 & 0.2 & NA \\
\hline Montmorillonite & 0.0 & 0.0 & 0.0 & 0.0 & 0.0 & 0.0 & 0.0 & NA \\
\hline K Al-Silicate & 1.7 & 0.9 & 0.4 & 0.0 & 0.2 & 0.0 & 3.2 & NA \\
\hline Fe Al-Silicate & 0.0 & 0.2 & 0.2 & 0.7 & 0.0 & 0.0 & 1.0 & NA \\
\hline Ca Al-Silicate & 0.4 & 0.1 & 0.1 & 0.0 & 0.0 & 0.0 & 0.6 & NA \\
\hline $\mathrm{Na}$ Al-Silicate & 0.0 & 0.3 & 0.1 & 0.3 & 0.0 & 0.0 & 0.7 & NA \\
\hline Aluminosilicate & 0.0 & 0.0 & 0.0 & 0.0 & 0.0 & 0.0 & 0.0 & NA \\
\hline Mixed Aluminosilicate & 0.0 & 0.4 & 0.4 & 0.0 & 0.0 & 0.0 & 0.8 & NA \\
\hline Fe Silicate & 0.0 & 0.0 & 0.0 & 0.0 & 0.0 & 0.0 & 0.0 & NA \\
\hline Ca Silicate & 0.4 & 1.2 & 0.1 & 0.0 & 0.0 & 0.0 & 1.6 & NA \\
\hline Ca Al-Silicate & 0.0 & 0.0 & 0.0 & 0.0 & 0.0 & 0.0 & 0.0 & NA \\
\hline Pyrite & 0.0 & 0.0 & 0.0 & 0.0 & 0.0 & 0.0 & 0.0 & NA \\
\hline Pyrrhotite & 0.0 & 0.0 & 0.0 & 0.0 & 0.0 & 0.0 & 0.0 & NA \\
\hline Oxidized Pyrrhotite & 0.0 & 0.0 & 0.0 & 1.0 & 0.0 & 0.0 & 1.0 & NA \\
\hline Gypsum & 0.1 & 0.2 & 0.0 & 0.7 & 0.0 & 0.0 & 1.0 & NA \\
\hline Barite & 0.0 & 0.0 & 0.0 & 0.0 & 0.0 & 0.0 & 0.0 & NA \\
\hline Apatite & 0.1 & 0.1 & 0.0 & 0.0 & 0.0 & 0.0 & 0.3 & NA \\
\hline Ca Al-Phosphate & 0.1 & 0.0 & 0.1 & 0.0 & 0.0 & 0.0 & 0.1 & NA \\
\hline $\mathrm{KCl}$ & 0.0 & 0.0 & 0.0 & 0.0 & 0.0 & 0.0 & 0.0 & NA \\
\hline Gypsum/Barite & 0.0 & 0.0 & 0.0 & 0.0 & 0.0 & 0.0 & 0.0 & NA \\
\hline Gypsum/Aluminosilicate & 0.2 & 1.5 & 0.5 & 0.3 & 0.1 & 0.0 & 2.5 & NA \\
\hline Silica-Rich & 0.2 & 0.8 & 0.4 & 0.7 & 0.5 & 0.2 & 2.7 & NA \\
\hline Ca-Rich & 0.6 & 0.4 & 0.2 & 0.0 & 0.1 & 0.0 & 1.4 & NA \\
\hline Ca-Si-Rich & 0.1 & 0.2 & 0.0 & 0.0 & 0.0 & 0.0 & 0.2 & NA \\
\hline Unknown & 10.1 & 16.9 & 8.4 & 1.5 & 1.1 & 0.0 & 37.9 & NA \\
\hline Totals & 19.6 & 34.6 & 20.3 & 15.8 & 5.1 & 4.5 & 100.0 & \\
\hline
\end{tabular}


C-6. Wood Chips CCSEM Mineral Distribution 
State Penitentiary

DMC 08/09/01

Table C-6. Wood Chips CCSEM Mineral Distribution, wt\%

Mineral Fraction: $\quad 1.467$

Size Bins:

$1.0-2.2 \quad 2.2-4.6 \quad 4.6-10$

$10-22$

$22-46 \quad 46-100$

Total \% Excluded

\begin{tabular}{|c|c|c|c|c|c|c|c|c|}
\hline Quartz & 0.1 & 0.0 & 5.1 & 1.3 & 0.2 & 0.0 & 6.7 & NA \\
\hline Iron Oxide & 0.1 & 0.0 & 23.3 & 3.6 & 0.5 & 0.0 & 27.4 & NA \\
\hline Periclase & 0.1 & 0.0 & 0.0 & 0.0 & 0.0 & 0.0 & 0.0 & NA \\
\hline Rutile & 0.1 & 0.0 & 0.2 & 0.0 & 0.0 & 0.0 & 0.2 & NA \\
\hline Alumina & 0.1 & 0.0 & 0.7 & 0.0 & 0.0 & 0.0 & 0.7 & NA \\
\hline Calcite & 0.1 & 0.0 & 0.6 & 0.0 & 0.0 & 0.0 & 0.6 & NA \\
\hline Dolomite & 0.1 & 0.0 & 0.0 & 0.0 & 0.0 & 0.0 & 0.0 & NA \\
\hline Ankerite & 0.1 & 0.0 & 0.2 & 0.0 & 0.0 & 0.0 & 0.2 & NA \\
\hline Kaolinite & 0.1 & 0.0 & 2.8 & 0.0 & 0.0 & 0.0 & 2.8 & NA \\
\hline Montmorillonite & 0.1 & 0.0 & 0.8 & 0.0 & 0.0 & 0.0 & 0.8 & NA \\
\hline K Al-Silicate & 0.1 & 0.0 & 4.1 & 2.1 & 0.2 & 0.1 & 6.5 & NA \\
\hline Fe Al-Silicate & 0.1 & 0.0 & 1.7 & 0.0 & 0.3 & 0.0 & 2.0 & NA \\
\hline Ca Al-Silicate & 0.1 & 0.0 & 1.4 & 0.6 & 0.0 & 0.0 & 2.0 & NA \\
\hline Na Al-Silicate & 0.1 & 0.0 & 0.3 & 0.2 & 0.0 & 0.0 & 0.5 & NA \\
\hline Aluminosilicate & 0.1 & 0.0 & 0.0 & 0.0 & 0.1 & 0.0 & 0.1 & NA \\
\hline Mixed Aluminosilicate & 0.1 & 0.0 & 5.1 & 0.9 & 0.4 & 0.0 & 6.4 & NA \\
\hline Fe Silicate & 0.1 & 0.0 & 2.9 & 1.1 & 0.0 & 0.0 & 4.0 & NA \\
\hline Ca Silicate & 0.1 & 0.0 & 0.2 & 0.0 & 0.0 & 0.0 & 0.2 & NA \\
\hline Ca Al-Silicate & 0.1 & 0.0 & 0.3 & 0.0 & 0.1 & 0.0 & 0.4 & NA \\
\hline Pyrite & 0.1 & 0.0 & 0.0 & 0.0 & 0.0 & 0.0 & 0.0 & NA \\
\hline Pyrrhotite & 0.1 & 0.0 & 0.8 & 0.0 & 0.0 & 0.0 & 0.8 & NA \\
\hline Oxidized Pyrrhotite & 0.1 & 0.0 & 5.8 & 2.3 & 0.0 & 0.0 & 8.1 & NA \\
\hline Gypsum & 0.1 & 0.0 & 0.8 & 0.0 & 0.0 & 0.0 & 0.8 & NA \\
\hline Barite & 0.1 & 0.0 & 0.0 & 0.0 & 0.0 & 0.0 & 0.0 & NA \\
\hline Apatite & 0.1 & 0.0 & 0.0 & 0.0 & 0.0 & 0.0 & 0.0 & NA \\
\hline Ca Al-Phosphate & 0.1 & 0.0 & 0.0 & 0.0 & 0.0 & 0.0 & 0.0 & NA \\
\hline $\mathrm{KCl}$ & 0.1 & 0.0 & 0.0 & 0.0 & 0.0 & 0.0 & 0.0 & NA \\
\hline Gypsum/Barite & 0.1 & 0.0 & 0.0 & 0.0 & 0.0 & 0.0 & 0.0 & NA \\
\hline Gypsum/Aluminosilicate & 0.1 & 0.0 & 1.7 & 0.0 & 0.1 & 0.0 & 1.8 & NA \\
\hline Silica-Rich & 0.1 & 0.0 & 1.3 & 1.0 & 0.1 & 0.0 & 2.4 & NA \\
\hline Ca-Rich & 0.1 & 0.0 & 0.4 & 0.0 & 0.0 & 0.0 & 0.4 & NA \\
\hline Ca-Si-Rich & 0.1 & 0.0 & 0.6 & 0.0 & 0.0 & 0.0 & 0.6 & NA \\
\hline Unknown & 0.1 & 0.3 & 15.8 & 4.9 & 2.3 & 0.2 & 23.5 & NA \\
\hline Totals & 3.3 & 0.3 & 77.0 & 18.0 & 4.4 & 0.3 & 100.0 & \\
\hline
\end{tabular}


C-7. Chemical Fractionation Analysis 
State Penitentiary

DMC 08/09/01

Table C-7. Chemical Fractionation Analysis, \%

Lignite

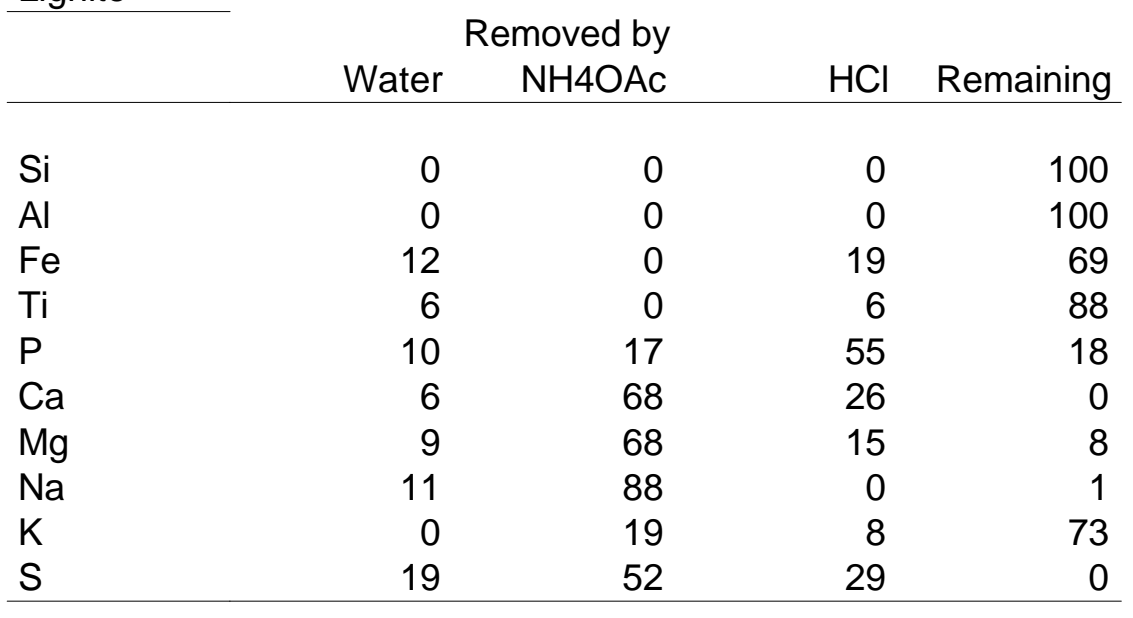

Tree Wood

\begin{tabular}{|c|c|c|c|c|}
\hline & \multicolumn{2}{|c|}{ Removed by } & \multirow[b]{2}{*}{$\mathrm{HCl}$} & \multirow[b]{2}{*}{ Remaining } \\
\hline & Water & $\mathrm{NH} 4 \mathrm{OAc}$ & & \\
\hline $\mathrm{Si}$ & 36 & 17 & 29 & 18 \\
\hline $\mathrm{Al}$ & 29 & 26 & 33 & 12 \\
\hline $\mathrm{Fe}$ & 66 & 5 & 28 & 1 \\
\hline $\mathrm{Ti}$ & 34 & 32 & 25 & 9 \\
\hline$P$ & 50 & 40 & 9 & 1 \\
\hline $\mathrm{Ca}$ & 19 & 51 & 30 & 0 \\
\hline $\mathrm{Mg}$ & 32 & 60 & 7 & 1 \\
\hline $\mathrm{Na}$ & 57 & 0 & 11 & 32 \\
\hline $\mathrm{K}$ & 48 & 52 & 0 & 0 \\
\hline $\mathrm{S}$ & 28 & 32 & 39 & 1 \\
\hline
\end{tabular}

Wood Chips

Water $\begin{array}{r}\text { Removed by } \\ \mathrm{NH} 4 \mathrm{OAc}\end{array} \mathrm{HCl}$ Remaining

\begin{tabular}{lrrrr}
$\mathrm{Si}$ & 76 & 0 & 1 & 23 \\
$\mathrm{Al}$ & 75 & 0 & 13 & 12 \\
$\mathrm{Fe}$ & 66 & 0 & 25 & 9 \\
$\mathrm{Ti}$ & 67 & 0 & 0 & 33 \\
$\mathrm{P}$ & 61 & 18 & 13 & 8 \\
$\mathrm{Ca}$ & 76 & 21 & 2 & 1 \\
$\mathrm{Mg}$ & 84 & 12 & 2 & 2 \\
$\mathrm{Na}$ & 87 & 9 & 2 & 2 \\
$\mathrm{~K}$ & 90 & 0 & 10 & 0 \\
$\mathrm{~S}$ & 52 & 44 & 4 & 0 \\
\hline
\end{tabular}


C-8. Summary of FACT Lignite-Tree Wood Viscosities 
State Penitentiary Project

DMC 07/26/01

Table C-8. Summary of FACT Lignite-Tree Wood Viscosities

Blend \%

Lignite

Tree Wood

$\begin{array}{rr}100 & 80 \\ 0 & 20\end{array}$

60

40

20

0

60

80

100

Temperature, ${ }^{\circ} \mathrm{C}$ Viscosity, $\log 10$ poise

\begin{tabular}{|c|c|c|c|c|c|}
\hline 1500 & 0.70 & 0.63 & 0.53 & 0.44 & 0.26 \\
\hline 1475 & 0.76 & 0.69 & 0.59 & 0.50 & 0.32 \\
\hline 1450 & 0.83 & 0.75 & 0.65 & 0.57 & 0.38 \\
\hline 1425 & 0.90 & 0.82 & 0.73 & 0.65 & 0.45 \\
\hline 1400 & 0.97 & 0.89 & 0.81 & 0.72 & 0.52 \\
\hline 1375 & 1.04 & 0.96 & 0.89 & 0.79 & 0.59 \\
\hline 1350 & 1.11 & 1.06 & 0.97 & 0.86 & 0.70 \\
\hline 1325 & 1.19 & 1.14 & 1.05 & 0.93 & 0.80 \\
\hline 1300 & 1.28 & 1.22 & 1.13 & 1.00 & 0.91 \\
\hline 1275 & 1.36 & 1.30 & 1.24 & 1.11 & 1.01 \\
\hline 1250 & 1.47 & 1.42 & 1.35 & 1.21 & 1.13 \\
\hline 1225 & 1.58 & 1.54 & 1.47 & 1.32 & 1.44 \\
\hline 1200 & 1.70 & 1.66 & 1.58 & 1.44 & 1.52 \\
\hline 1175 & 1.81 & 1.76 & 1.69 & 1.57 & 1.61 \\
\hline 1150 & 1.91 & 1.84 & 1.80 & 1.69 & 1.69 \\
\hline 1125 & 2.04 & 1.96 & 1.88 & 1.81 & 1.79 \\
\hline 1100 & 2.18 & 2.10 & 1.97 & 2.10 & 1.90 \\
\hline 1075 & 2.31 & 2.23 & 2.10 & 2.26 & 2.07 \\
\hline 1050 & 2.41 & 2.31 & 2.23 & NA & 2.23 \\
\hline 1025 & 2.53 & 2.48 & 2.40 & NA & 2.39 \\
\hline 1000 & 2.62 & 2.68 & 2.63 & 2.54 & 2.51 \\
\hline 975 & 2.88 & 2.81 & 2.88 & 2.70 & 2.64 \\
\hline 950 & 3.09 & 3.03 & 3.07 & 2.93 & 2.77 \\
\hline 925 & 3.32 & 3.25 & 3.21 & 3.20 & 2.90 \\
\hline 900 & 3.51 & 3.48 & 3.43 & NA & 3.04 \\
\hline 875 & 3.75 & 3.64 & 3.63 & NA & 3.17 \\
\hline 850 & NA & NA & NA & NA & 3.31 \\
\hline 825 & NA & NA & NA & NA & 3.45 \\
\hline 800 & NA & NA & NA & NA & 3.59 \\
\hline 775 & NA & NA & NA & NA & 3.71 \\
\hline 750 & NA & NA & NA & NA & 3.80 \\
\hline 725 & NA & NA & NA & NA & 3.82 \\
\hline 700 & NA & NA & NA & NA & 3.72 \\
\hline 675 & NA & NA & NA & NA & 3.95 \\
\hline 650 & NA & NA & NA & NA & 4.05 \\
\hline 625 & NA & NA & NA & NA & 4.14 \\
\hline 600 & NA & NA & NA & NA & 4.47 \\
\hline 575 & NA & NA & NA & NA & 4.60 \\
\hline 550 & NA & NA & NA & NA & 4.74 \\
\hline 525 & NA & NA & NA & 3.96 & 3.98 \\
\hline 500 & NA & NA & NA & 4.23 & 3.66 \\
\hline
\end{tabular}




\section{C-9. Summary of FACT Lignite-Wood Chip Viscosities}


State Penitentiary Project

DMC 07/26/01

Table C-9. Summary of FACT Lignite-Wood Chips Viscosities

Blend \%

Lignite

$\begin{array}{rr}100 & 80 \\ 0 & 20\end{array}$

60

40

20

0

Wood Chips

$20 \quad 40$

60

80

100

Temperature, ${ }^{\circ} \mathrm{C} \quad$ Viscosity, $\log 10$ poise

\begin{tabular}{|c|c|c|c|c|c|c|}
\hline 1500 & 0.70 & 0.70 & 0.71 & 0.71 & 0.71 & 0.67 \\
\hline 1475 & 0.76 & 0.77 & 0.77 & 0.77 & 0.78 & 0.73 \\
\hline 1450 & 0.83 & 0.83 & 0.83 & 0.84 & 0.84 & 0.80 \\
\hline 1425 & 0.90 & 0.90 & 0.90 & 0.91 & 0.91 & 0.87 \\
\hline 1400 & 0.97 & 0.97 & 0.97 & 0.98 & 0.98 & 0.94 \\
\hline 1375 & 1.04 & 1.04 & 1.04 & 1.05 & 1.05 & 1.01 \\
\hline 1350 & 1.11 & 1.11 & 1.12 & 1.12 & 1.13 & 1.09 \\
\hline 1325 & 1.19 & 1.19 & 1.19 & 1.20 & 1.20 & 1.16 \\
\hline 1300 & 1.28 & 1.27 & 1.27 & 1.29 & 1.32 & 1.27 \\
\hline 1275 & 1.36 & 1.36 & 1.38 & 1.41 & 1.45 & 1.41 \\
\hline 1250 & 1.47 & 1.48 & 1.51 & 1.54 & 1.58 & 1.56 \\
\hline 1225 & 1.58 & 1.60 & 1.63 & 1.66 & 1.71 & 1.73 \\
\hline 1200 & 1.70 & 1.72 & 1.75 & 1.79 & 1.84 & 1.89 \\
\hline 1175 & 1.81 & 1.84 & 1.87 & 1.92 & 1.98 & 2.05 \\
\hline 1150 & 1.91 & 1.94 & 1.98 & 2.03 & 2.11 & 2.21 \\
\hline 1125 & 2.04 & 2.04 & 2.08 & 2.14 & 2.24 & 2.38 \\
\hline 1100 & 2.18 & 2.18 & 2.18 & 2.24 & 2.35 & 2.54 \\
\hline 1075 & 2.31 & 2.31 & 2.32 & 2.33 & 2.46 & 2.72 \\
\hline 1050 & 2.41 & 2.42 & 2.43 & 2.44 & 2.54 & 2.89 \\
\hline 1025 & 2.53 & 2.54 & 2.52 & 2.54 & 2.60 & 3.04 \\
\hline 1000 & 2.62 & 2.63 & 2.64 & 2.66 & 2.68 & 3.14 \\
\hline 975 & 2.88 & 2.87 & 2.85 & 2.81 & 2.81 & 3.16 \\
\hline 950 & 3.09 & 3.08 & 3.07 & 3.06 & 3.11 & 3.16 \\
\hline 925 & 3.32 & 3.32 & 3.32 & 3.32 & 3.40 & 3.42 \\
\hline 900 & 3.51 & 3.51 & 3.54 & 3.55 & 3.58 & 3.62 \\
\hline 875 & 3.75 & 3.75 & 3.78 & 3.82 & 3.83 & NA \\
\hline 850 & NA & NA & NA & NA & NA & NA \\
\hline 825 & NA & NA & NA & NA & NA & NA \\
\hline 800 & NA & NA & NA & NA & NA & NA \\
\hline 775 & NA & NA & NA & NA & NA & NA \\
\hline 750 & NA & NA & NA & NA & NA & NA \\
\hline 725 & NA & NA & NA & NA & NA & NA \\
\hline 700 & NA & NA & NA & NA & NA & NA \\
\hline 675 & NA & NA & NA & NA & NA & NA \\
\hline 650 & NA & NA & NA & NA & NA & NA \\
\hline 625 & NA & NA & NA & NA & NA & NA \\
\hline 600 & NA & NA & NA & NA & NA & NA \\
\hline 575 & NA & NA & NA & NA & NA & NA \\
\hline 550 & NA & NA & NA & NA & NA & NA \\
\hline 525 & NA & NA & NA & NA & NA & NA \\
\hline 500 & NA & NA & NA & NA & NA & NA \\
\hline
\end{tabular}


C-10. Summary of FACT Lignite-Tree Wood Liquid Phases 
Table C-10. Summary of FACT Lignite-Tree Wood Liquid Phases

$\begin{array}{lrrrrrr}\text { Lignite } & 100 & 80 & 60 & 40 & 20 & 0 \\ \text { Tree Wood } & 0 & 20 & 40 & 60 & 80 & 100\end{array}$

Temperature, ${ }^{\circ} \mathrm{C} \%$ of Liquid Phases

\begin{tabular}{|c|c|c|c|c|c|c|}
\hline 1500 & 84.95 & 85.79 & 86.98 & 84.83 & 83.35 & 51.60 \\
\hline 1475 & 84.96 & 85.80 & 86.97 & 83.84 & 82.25 & 50.42 \\
\hline 1450 & 84.99 & 85.81 & 86.97 & 82.85 & 81.27 & 49.28 \\
\hline 1425 & 85.02 & 85.84 & 86.07 & 81.86 & 80.30 & 21.97 \\
\hline 1400 & 85.05 & 85.87 & 84.95 & 80.95 & 79.41 & 14.52 \\
\hline 1375 & 85.09 & 85.90 & 83.76 & 80.95 & 78.48 & 11.55 \\
\hline 1350 & 85.13 & 83.61 & 83.20 & 80.97 & 67.12 & 9.35 \\
\hline 1325 & 84.36 & 83.25 & 82.67 & 81.01 & 59.71 & 6.09 \\
\hline 1300 & 84.16 & 83.29 & 82.21 & 79.82 & 54.08 & 5.10 \\
\hline 1275 & 84.02 & 82.73 & 78.62 & 74.37 & 49.46 & 4.82 \\
\hline 1250 & 81.82 & 78.14 & 74.00 & 69.69 & 43.23 & 4.66 \\
\hline 1225 & 77.84 & 74.44 & 70.10 & 64.93 & 19.31 & 4.57 \\
\hline 1200 & 75.12 & 71.48 & 66.89 & 60.79 & 19.02 & 4.51 \\
\hline 1175 & 73.54 & 69.34 & 64.72 & 56.70 & 18.92 & 4.49 \\
\hline 1150 & 72.99 & 68.83 & 62.21 & 50.23 & 16.63 & 3.73 \\
\hline 1125 & 70.60 & 65.41 & 59.86 & 46.58 & 14.94 & 3.30 \\
\hline 1100 & 67.72 & 61.41 & 55.43 & 30.80 & 13.65 & 3.02 \\
\hline 1075 & 66.37 & 59.56 & 49.53 & 27.84 & 12.44 & 2.87 \\
\hline 1050 & 64.59 & 56.66 & 42.20 & 0.00 & 11.69 & 2.70 \\
\hline 1025 & 63.03 & 52.82 & 38.45 & 0.00 & 9.21 & 2.53 \\
\hline 1000 & 63.36 & 49.75 & 35.32 & 0.48 & 5.15 & 2.42 \\
\hline 975 & 60.25 & 49.18 & 33.15 & 14.27 & 3.47 & 2.33 \\
\hline 950 & 60.26 & 50.89 & 33.69 & 15.96 & 2.78 & 2.27 \\
\hline 925 & 57.20 & 50.33 & 35.82 & 15.15 & 2.51 & 2.23 \\
\hline 900 & 49.72 & 36.66 & 11.13 & 0.00 & 2.41 & 2.22 \\
\hline 875 & 43.23 & 3.93 & 12.04 & 0.00 & 2.38 & 2.23 \\
\hline 850 & 0.00 & 0.00 & 0.00 & 0.00 & 2.37 & 2.29 \\
\hline 825 & 0.00 & 0.00 & 0.00 & 0.00 & 2.36 & 2.42 \\
\hline 800 & NA & 0.00 & 0.00 & 0.00 & 2.30 & 2.70 \\
\hline 775 & NA & 0.00 & 0.00 & 0.00 & 2.28 & 3.42 \\
\hline 750 & NA & 0.00 & 0.00 & 0.00 & 2.27 & 4.22 \\
\hline 725 & 0.00 & 0.00 & 0.00 & 0.00 & 2.28 & 3.07 \\
\hline 700 & 0.00 & 0.00 & 0.00 & 0.00 & 2.35 & 2.13 \\
\hline 675 & 0.00 & 0.00 & 0.00 & 0.00 & 7.28 & 1.57 \\
\hline 650 & 0.00 & 0.00 & 0.00 & 0.00 & 7.09 & 1.56 \\
\hline 625 & 0.00 & NA & NA & 0.00 & 6.92 & 1.87 \\
\hline 600 & NA & NA & NA & 0.00 & 11.47 & NA \\
\hline 575 & NA & NA & NA & 0.00 & 11.46 & NA \\
\hline 550 & NA & 0.00 & NA & 0.00 & 11.70 & NA \\
\hline 525 & NA & 0.00 & NA & 10.19 & 17.19 & NA \\
\hline 500 & NA & NA & NA & 10.28 & 22.29 & NA \\
\hline
\end{tabular}




\section{C-11. Summary of FACT Lignite-Wood Chip Liquid Phases}


State Penitentiary Project

DMC 07/26/01

Table C-11. Summary of FACT Lignite-Wood Chips Liquid Phases

Lignite

Wood Chips
100

0
80

Temperature, ${ }^{\circ} \mathrm{C} \quad \%$ of Liquid Phases

$\begin{array}{lrrrrrr}1500 & 84.95 & 85.03 & 85.17 & 85.47 & 86.15 & 88.91 \\ 1475 & 84.96 & 85.04 & 85.17 & 85.44 & 86.07 & 88.58 \\ 1450 & 84.99 & 85.06 & 85.18 & 85.43 & 86.01 & 88.33 \\ 1425 & 85.02 & 85.09 & 85.20 & 85.44 & 85.98 & 88.13 \\ 1400 & 85.05 & 85.12 & 85.22 & 85.45 & 85.97 & 87.99 \\ 1375 & 85.09 & 85.16 & 85.25 & 85.47 & 85.97 & 87.88 \\ 1350 & 85.13 & 85.20 & 85.29 & 85.50 & 85.98 & 87.81 \\ 1325 & 84.36 & 84.83 & 84.92 & 85.13 & 85.61 & 87.42 \\ 1300 & 84.16 & 84.71 & 84.96 & 83.93 & 81.13 & 83.75 \\ 1275 & 84.02 & 84.24 & 81.63 & 78.81 & 76.03 & 77.32 \\ 1250 & 81.82 & 79.51 & 77.33 & 74.65 & 71.90 & 71.20 \\ 1225 & 77.84 & 75.96 & 73.86 & 71.26 & 68.51 & 65.97 \\ 1200 & 75.12 & 73.31 & 71.18 & 68.53 & 65.69 & 61.85 \\ 1175 & 73.54 & 71.62 & 69.33 & 66.48 & 63.39 & 58.01 \\ 1150 & 72.99 & 70.94 & 68.43 & 65.22 & 61.61 & 53.69 \\ 1125 & 70.60 & 71.18 & 68.52 & 64.88 & 60.48 & 50.33 \\ 1100 & 67.72 & 67.91 & 68.59 & 65.51 & 60.17 & 47.67 \\ 1075 & 66.37 & 66.40 & 66.74 & 67.03 & 60.82 & 45.29 \\ 1050 & 64.59 & 64.67 & 65.44 & 66.84 & 62.41 & 43.82 \\ 1025 & 63.03 & 62.89 & 64.25 & 65.19 & 64.34 & 42.95 \\ 1000 & 63.36 & 63.41 & 63.29 & 63.86 & 65.19 & 43.32 \\ 975 & 60.25 & 59.31 & 60.48 & 62.66 & 64.43 & 43.69 \\ 950 & 60.26 & 60.81 & 61.69 & 62.78 & 61.48 & 34.77 \\ 925 & 57.20 & 57.45 & 57.93 & 58.89 & 56.45 & 28.54 \\ 900 & 49.72 & 47.79 & 46.16 & 43.90 & 38.64 & 18.62 \\ 875 & 43.23 & 45.23 & 43.59 & 40.35 & 12.28 & 0.00 \\ 850 & 0.00 & 0.00 & 0.00 & 0.00 & 0.00 & 0.00 \\ 825 & 0.00 & 0.00 & 0.00 & 0.00 & 0.00 & 0.00 \\ 800 & \text { NA } & 0.00 & \text { NA } & 0.00 & 0.00 & 0.00 \\ 775 & \text { NA } & \text { NA } & \text { NA } & \text { NA } & 0.00 & 0.00 \\ 750 & \text { NA } & \text { NA } & \text { NA } & \text { NA } & 0.00 & 0.00 \\ 725 & 0.00 & 0.00 & 0.00 & 0.00 & 0.00 & 0.00 \\ 700 & 0.00 & \text { NA } & \text { NA } & 0.00 & 0.00 & 0.00 \\ 675 & 0.00 & \text { NA } & \text { NA } & 0.00 & 0.00 & 0.00 \\ 650 & 0.00 & \text { NA } & \text { NA } & \text { NA } & 0.00 & 0.00 \\ 625 & 0.00 & 0.00 & \text { NA } & \text { NA } & 0.00 & 0.00 \\ 600 & \text { NA } & \text { NA } & 0.00 & \text { NA } & \text { NA } & 0.00 \\ 575 & \text { NA } & \text { NA } & \text { NA } & \text { NA } & \text { NA } & 0.00 \\ 550 & \text { NA } & \text { NA } & \text { NA } & \text { NA } & \text { NA } & 0.00 \\ 525 & \text { NA } & \text { NA } & \text { NA } & \text { NA } & \text { NA } & 0.00 \\ 500 & \text { NA } & \text { NA } & \text { NA } & \text { NA } & \text { NA } & 0.00 \\ & & & & & & \end{array}$


C-12. Summary of FACT Lignite-Tree Wood Solid Sulfates 
State Penitentiary Project

DMC 07/26/01

Table C-12. Summary of FACT Lignite-Tree Wood Solid Sulfates

\begin{tabular}{|c|c|c|c|c|c|c|}
\hline Lignite & 100 & 80 & 60 & 40 & 20 & 0 \\
\hline Tree Wood & 0 & 20 & 40 & 60 & 80 & 100 \\
\hline \multicolumn{7}{|c|}{ Temperature, ${ }^{\circ} \mathrm{C} \%$ Solid Sulfates } \\
\hline 1500 & 0.00 & 0.00 & 0.00 & 0.00 & 0.00 & 0.00 \\
\hline 1475 & 0.00 & 0.00 & 0.00 & 0.00 & 0.00 & 0.00 \\
\hline 1450 & 0.00 & 0.00 & 0.00 & 0.00 & 0.00 & 0.00 \\
\hline 1425 & 0.00 & 0.00 & 0.00 & 0.00 & 0.00 & 0.00 \\
\hline 1400 & 0.00 & 0.00 & 0.00 & 0.00 & 0.00 & 0.00 \\
\hline 1375 & 0.00 & 0.00 & 0.00 & 0.00 & 0.00 & 0.00 \\
\hline 1350 & 0.00 & 0.00 & 0.00 & 0.00 & 0.00 & 0.00 \\
\hline 1325 & 0.00 & 0.00 & 0.00 & 0.00 & 0.00 & 0.00 \\
\hline 1300 & 0.00 & 0.00 & 0.00 & 0.00 & 0.00 & 0.00 \\
\hline 1275 & 0.00 & 0.00 & 0.00 & 0.00 & 0.00 & 0.00 \\
\hline 1250 & 0.00 & 0.00 & 0.00 & 0.00 & 0.00 & 0.00 \\
\hline 1225 & 0.00 & 0.00 & 0.00 & 0.00 & 0.00 & 0.00 \\
\hline 1200 & 0.00 & 0.00 & 0.00 & 0.00 & 0.00 & 0.00 \\
\hline 1175 & 0.00 & 0.00 & 0.00 & 0.00 & 0.00 & 0.00 \\
\hline 1150 & 0.00 & 0.00 & 2.07 & 6.81 & 12.54 & 16.81 \\
\hline 1125 & 1.12 & 2.44 & 5.82 & 11.51 & 21.09 & 26.79 \\
\hline 1100 & 2.63 & 5.61 & 9.82 & 17.34 & 29.23 & 34.14 \\
\hline 1075 & 3.92 & 7.51 & 12.55 & 19.75 & 32.87 & 37.96 \\
\hline 1050 & 5.30 & 9.07 & 14.89 & 28.44 & 35.21 & 39.89 \\
\hline 1025 & 8.03 & 13.26 & 18.42 & 31.87 & 37.68 & 40.88 \\
\hline 1000 & 9.68 & 18.15 & 22.95 & 32.21 & 40.16 & 41.40 \\
\hline 975 & 18.92 & 20.02 & 27.37 & 33.08 & 41.29 & 41.67 \\
\hline 950 & 23.96 & 25.98 & 30.28 & 34.76 & 41.79 & 41.80 \\
\hline 925 & 26.36 & 29.10 & 31.56 & 36.55 & 42.01 & 41.87 \\
\hline 900 & 29.59 & 32.67 & 38.01 & 40.78 & 42.10 & 41.91 \\
\hline 875 & 31.38 & 39.66 & 38.79 & 41.65 & 42.13 & 41.92 \\
\hline 850 & 40.85 & 40.73 & 41.28 & 42.00 & 42.14 & 41.93 \\
\hline 825 & 41.15 & 40.88 & 41.44 & 42.13 & 42.15 & 41.92 \\
\hline 800 & NA & 40.94 & 41.50 & 42.19 & 42.17 & 41.90 \\
\hline 775 & NA & 40.96 & 41.53 & 42.20 & 42.18 & 41.86 \\
\hline 750 & NA & 40.97 & 41.54 & 42.21 & 42.19 & 38.22 \\
\hline 725 & 41.34 & 41.02 & 41.97 & 42.21 & 42.20 & 38.12 \\
\hline 700 & 41.35 & 41.02 & 41.89 & 42.21 & 42.20 & 37.99 \\
\hline 675 & 41.35 & 40.99 & 41.75 & 42.21 & 41.89 & 37.18 \\
\hline 650 & 41.35 & 40.99 & 41.75 & 42.21 & 41.84 & 37.14 \\
\hline 625 & 41.35 & NA & NA & 42.21 & 41.79 & 37.11 \\
\hline 600 & NA & NA & NA & 42.21 & 41.10 & NA \\
\hline 575 & NA & NA & NA & 42.21 & 40.86 & NA \\
\hline 550 & NA & 41.59 & NA & 42.21 & 40.47 & NA \\
\hline 525 & NA & 41.59 & NA & 41.14 & 40.70 & NA \\
\hline 500 & NA & NA & NA & 41.12 & 40.02 & NA \\
\hline
\end{tabular}


C-13. Summary of FACT Lignite-Wood Chip Solid Sulfates 
State Penitentiary Project

DMC 07/26/01

Table C-13. Summary of FACT Lignite-Wood Chips Solid Sulfates

$\begin{array}{lr}\text { Lignite } & 100 \\ \text { Wood Chips } & 0 \\ \text { Temperature, }{ }^{\circ} \mathrm{C} & \% \text { Solid Sulfates }\end{array}$

\begin{tabular}{|c|c|c|c|c|c|c|}
\hline 1500 & 0.00 & 0.00 & 0.00 & 0.00 & 0.00 & 0.00 \\
\hline 1475 & 0.00 & 0.00 & 0.00 & 0.00 & 0.00 & 0.00 \\
\hline 1450 & 0.00 & 0.00 & 0.00 & 0.00 & 0.00 & 0.00 \\
\hline 1425 & 0.00 & 0.00 & 0.00 & 0.00 & 0.00 & 0.00 \\
\hline 1400 & 0.00 & 0.00 & 0.00 & 0.00 & 0.00 & 0.00 \\
\hline 1375 & 0.00 & 0.00 & 0.00 & 0.00 & 0.00 & 0.00 \\
\hline 1350 & 0.00 & 0.00 & 0.00 & 0.00 & 0.00 & 0.00 \\
\hline 1325 & 0.00 & 0.00 & 0.00 & 0.00 & 0.00 & 0.00 \\
\hline 1300 & 0.00 & 0.00 & 0.00 & 0.00 & 0.00 & 0.00 \\
\hline 1275 & 0.00 & 0.00 & 0.00 & 0.00 & 0.00 & 0.00 \\
\hline 1250 & 0.00 & 0.00 & 0.00 & 0.00 & 0.00 & 0.00 \\
\hline 1225 & 0.00 & 0.00 & 0.00 & 0.00 & 0.00 & 0.00 \\
\hline 1200 & 0.00 & 0.00 & 0.00 & 0.00 & 0.00 & 0.00 \\
\hline 1175 & 0.00 & 0.00 & 0.00 & 0.00 & 0.00 & 0.00 \\
\hline 1150 & 0.00 & 0.00 & 0.00 & 0.00 & 0.00 & 0.00 \\
\hline 1125 & 1.12 & 0.02 & 0.00 & 0.00 & 0.00 & 0.00 \\
\hline 1100 & 2.63 & 1.78 & 0.40 & 0.00 & 0.00 & 0.00 \\
\hline 1075 & 3.92 & 3.02 & 1.82 & 0.00 & 0.00 & 0.00 \\
\hline 1050 & 5.30 & 4.61 & 3.35 & 0.03 & 0.00 & 0.00 \\
\hline 1025 & 8.03 & 7.43 & 4.66 & 0.09 & 0.00 & 0.00 \\
\hline 1000 & 9.68 & 8.67 & 8.11 & 0.20 & 2.28 & 0.00 \\
\hline 975 & 18.92 & 17.40 & 15.21 & 3.42 & 6.83 & 0.00 \\
\hline 950 & 23.96 & 23.66 & 23.15 & 15.47 & 19.73 & 11.14 \\
\hline 925 & 26.36 & 26.36 & 26.25 & 19.33 & 27.12 & 35.23 \\
\hline 900 & 29.59 & 30.51 & 31.42 & 28.85 & 34.75 & 43.49 \\
\hline 875 & 31.38 & 31.85 & 33.16 & 30.92 & 44.46 & 51.21 \\
\hline 850 & 40.85 & 41.85 & 43.36 & 29.81 & 48.35 & 52.30 \\
\hline 825 & 41.15 & 42.20 & 43.80 & 30.46 & 48.85 & 52.64 \\
\hline 800 & NA & 42.35 & NA & 30.70 & 48.94 & 52.83 \\
\hline 775 & NA & NA & NA & NA & 50.10 & 54.41 \\
\hline 750 & NA & NA & NA & NA & 50.12 & 54.46 \\
\hline 725 & 41.34 & 42.44 & 44.08 & 30.80 & 51.06 & 56.45 \\
\hline 700 & 41.35 & NA & NA & 30.79 & 51.52 & 56.64 \\
\hline 675 & 41.35 & NA & NA & 30.78 & 51.68 & 57.06 \\
\hline 650 & 41.35 & NA & NA & NA & 51.72 & 57.75 \\
\hline 625 & 41.35 & 42.44 & NA & NA & 51.74 & 59.18 \\
\hline 600 & NA & NA & 43.91 & NA & NA & 60.84 \\
\hline 575 & NA & NA & NA & NA & NA & 63.26 \\
\hline 550 & NA & NA & NA & NA & NA & 68.48 \\
\hline 525 & NA & NA & NA & NA & NA & 69.69 \\
\hline 500 & NA & NA & NA & NA & NA & 69.69 \\
\hline
\end{tabular}


C-14. CCSEM Deposit Analysis of 50\% Pallet Wood and Lignite 


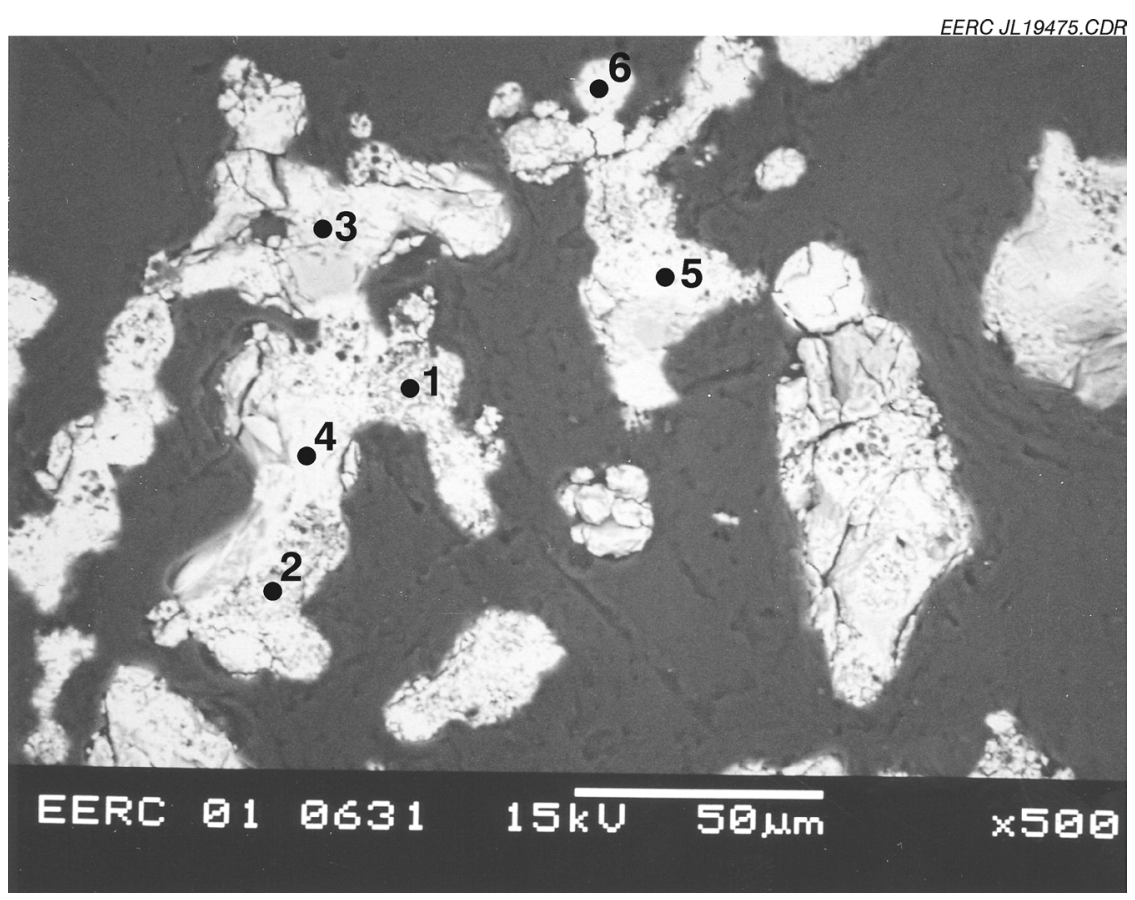

Table C-14. Pallet Wood Blend

\begin{tabular}{llrrrrrrrrr}
\hline Point & Description & $\mathrm{Na}$ & $\mathrm{Mg}$ & \multicolumn{1}{c}{$\mathrm{Al}$} & \multicolumn{1}{c}{$\mathrm{Si}$} & $\mathrm{P}$ & $\mathrm{S}$ & $\mathrm{Ca}$ & \multicolumn{1}{c}{$\mathrm{Fe}$} & $\mathrm{Ti}$ \\
\hline 1 & Matrix & $\mathrm{ND}$ & 12.5 & 18.0 & 1.2 & $\mathrm{ND}$ & 4.7 & 55.2 & 7.0 & $\mathrm{ND}$ \\
2 & Matrix & $\mathrm{ND}$ & 2.6 & 21.4 & 0.5 & $\mathrm{ND}$ & 7.5 & 60.0 & 6.3 & $\mathrm{ND}$ \\
3 & Matrix & 6.1 & 1.4 & 13.3 & 38.2 & $\mathrm{ND}$ & $\mathrm{ND}$ & 34.1 & 5.1 & $\mathrm{ND}$ \\
4 & Matrix & 3.2 & $\mathrm{ND}$ & 1.6 & 35.5 & $\mathrm{ND}$ & $\mathrm{ND}$ & 55.3 & 2.1 & $\mathrm{ND}$ \\
5 & Bright inclusion & $\mathrm{ND}$ & 11.2 & 13.6 & 11.8 & $\mathrm{ND}$ & $\mathrm{ND}$ & 38.4 & 24.2 & $\mathrm{ND}$ \\
6 & Matrix & $\mathrm{ND}$ & 0.5 & 1.6 & 18.9 & 1.2 & $\mathrm{ND}$ & 72 & 4 & 1 \\
\hline ND $=$ Not detected. & & & & & & & & &
\end{tabular}


C-15. CCSEM Deposit Analysis of 50\% Tree Wood and Lignite 


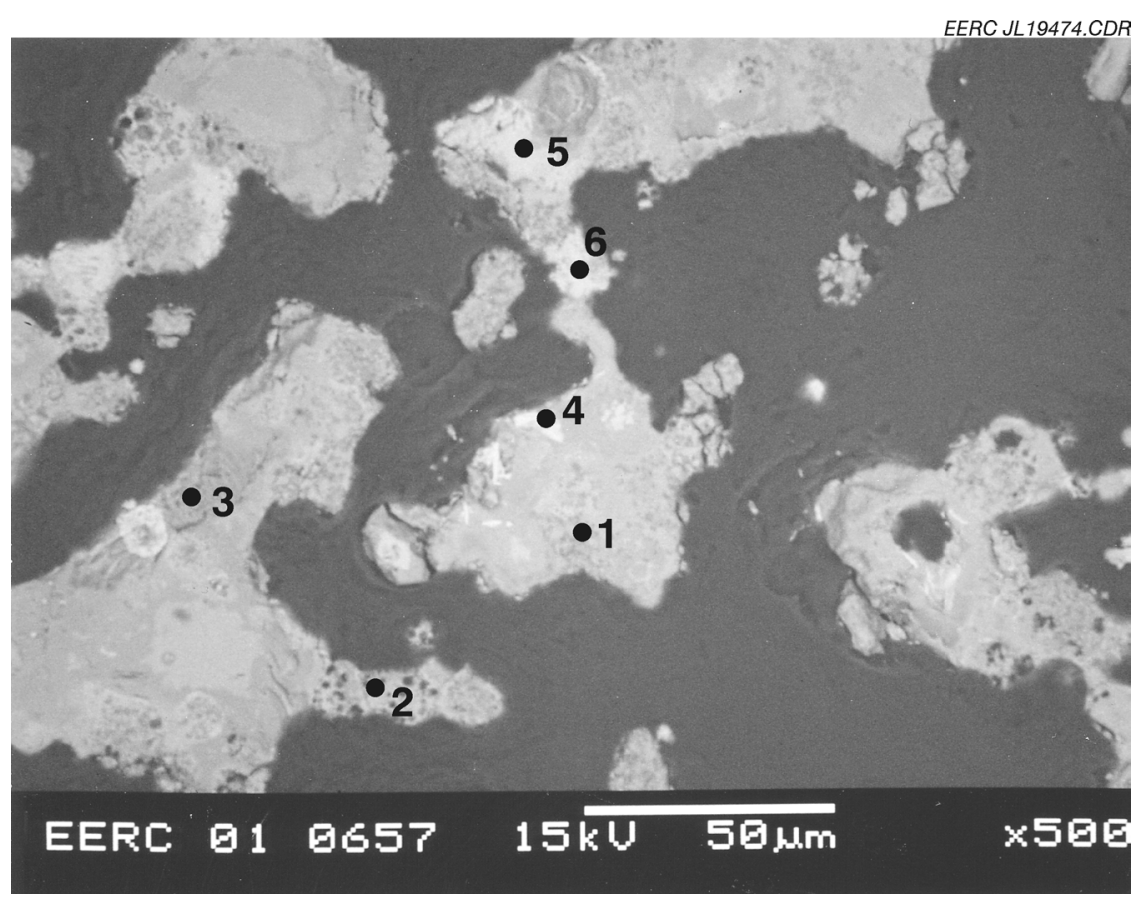

Table C-15. Green Wood Blend

\begin{tabular}{|c|c|c|c|c|c|c|c|c|c|c|c|}
\hline Point & Description & $\mathrm{Na}$ & $\mathrm{Mg}$ & $\mathrm{Al}$ & $\mathrm{Si}$ & $\mathrm{S}$ & $\mathrm{K}$ & $\mathrm{Ca}$ & $\mathrm{Fe}$ & $\mathrm{Ba}$ & $\mathrm{Ti}$ \\
\hline 1 & Matrix & ND & 23.5 & 16.4 & 1.0 & 0.7 & ND & 53.6 & 4.0 & ND & ND \\
\hline 2 & Matrix & 0.7 & 1.3 & 20.9 & 1.4 & 6.9 & 2.0 & 50.2 & 15.3 & ND & 1.1 \\
\hline 3 & Matrix & 6.7 & 1.3 & 20.5 & 33.9 & ND & 16.7 & 13.4 & 5.0 & 2.0 & ND \\
\hline 4 & Brigh & 1.5 & 0.6 & 0.5 & 0.7 & ND & ND & 2.7 & 92.3 & 1.1 & ND \\
\hline 5 & Brig & ND & 6.3 & 4.0 & 1.5 & ND & ND & 28.2 & 59.3 & ND & ND \\
\hline 6 & Bright inclusion & ND & ND & 2.7 & 1.8 & ND & ND & 43.1 & 50.9 & ND & ND \\
\hline
\end{tabular}


C-16. Gas Analysis of Drop-Tube Furnace Runs 
Table C-16. Gas Analysis for Drop-Tube Furnace Runs, averages for all runs

\begin{tabular}{lccccc}
\hline Sample & $\mathrm{O}_{2}, \%$ & $\mathrm{CO}_{2}, \%$ & $\mathrm{CO}, \mathrm{ppm}$ & $\mathrm{SO}_{2}, \mathrm{ppm}$ & $\mathrm{NO}_{x}, \mathrm{ppm}$ \\
\hline 100\% Lignite & 2.0 & 2.3 & 1.9 & 89.7 & 83.5 \\
50/50 Lignite-Green Wood & 2.1 & 1.9 & 2.0 & 59.9 & 65.5 \\
50/50 Lignite-Pallet Wood & 0.6 & 1.1 & 3.3 & 36.0 & 47.0 \\
\hline
\end{tabular}


C-17. Photographs of Lignite Fuel, Grate Combustion, Collected Ash 


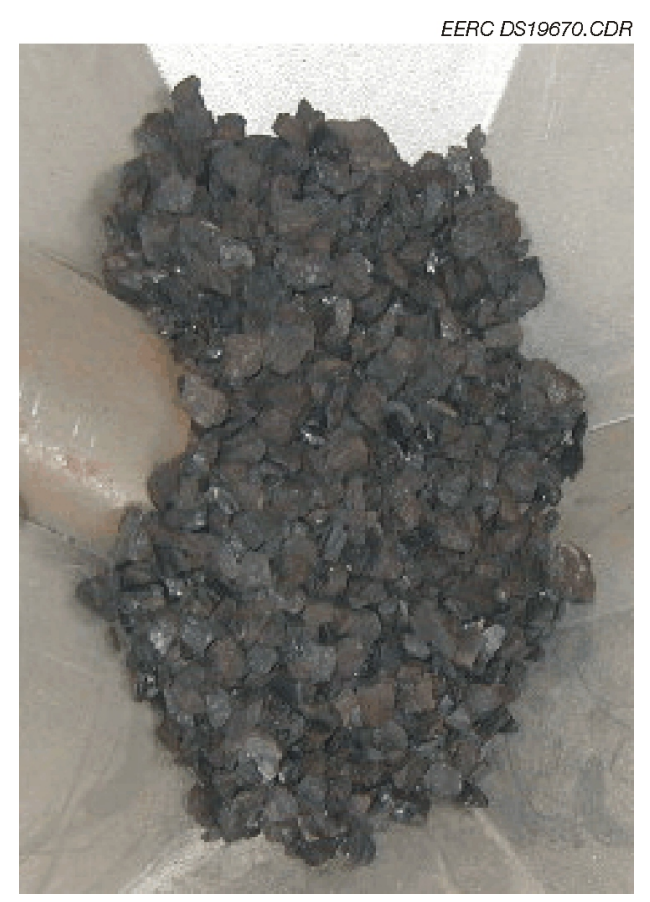

Figure C-17A. Lignite coal.

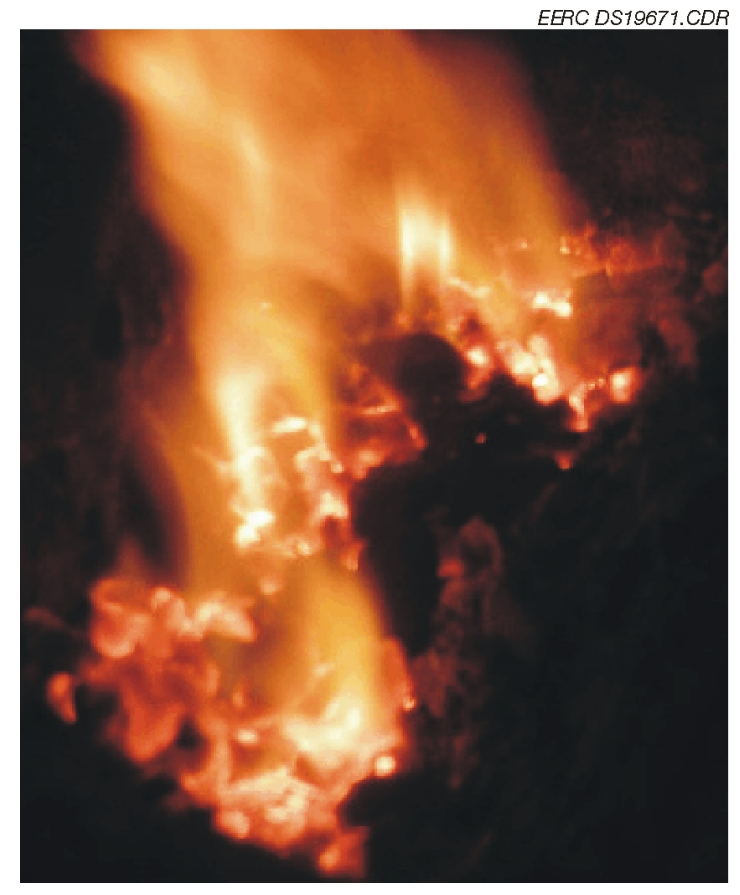

Figure C-17B. Burn on grate. 
EERC DS19672.CDR

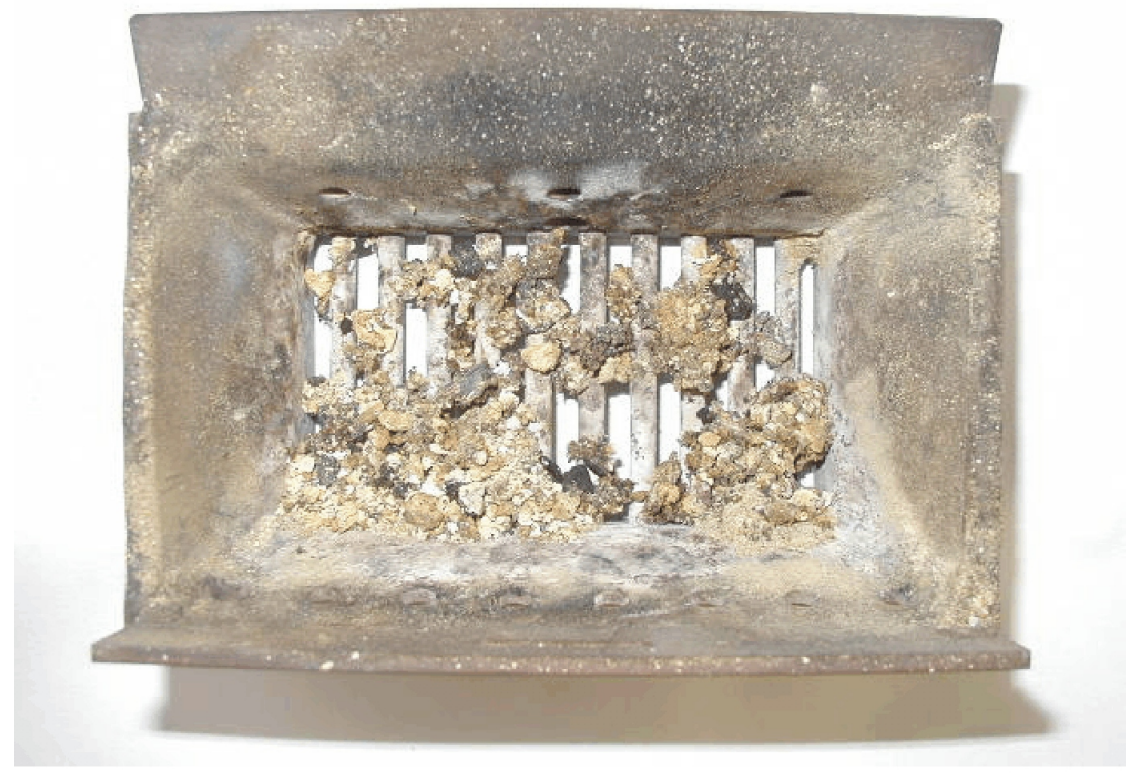

Figure C-17C. Clinkers. 
C-18. Photographs of $75 \%$ Wood Blend, Grate Combustion, Collected Ash 


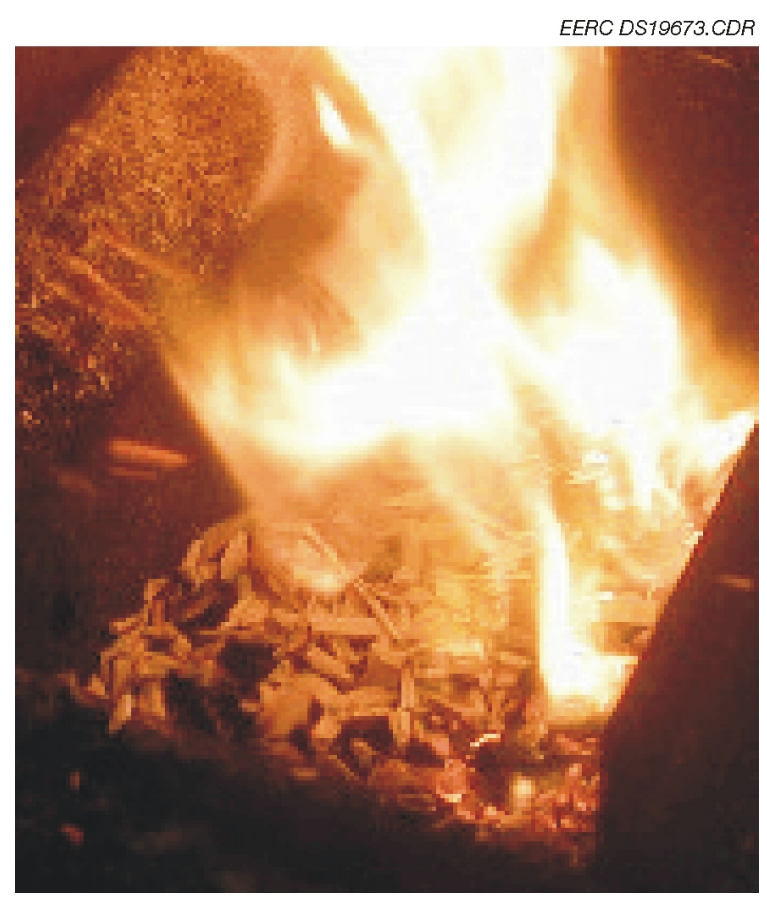

EERC DS19674.CDR

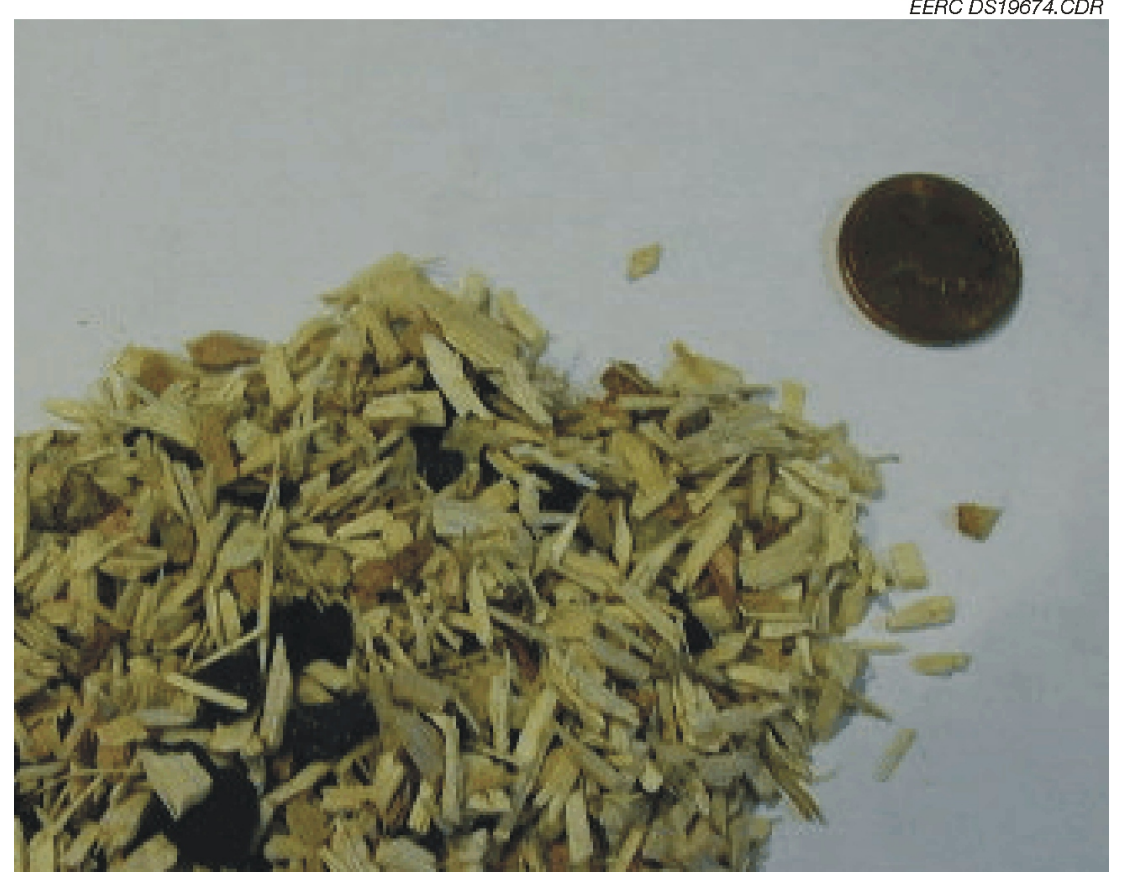


EERC DS19676.CDR

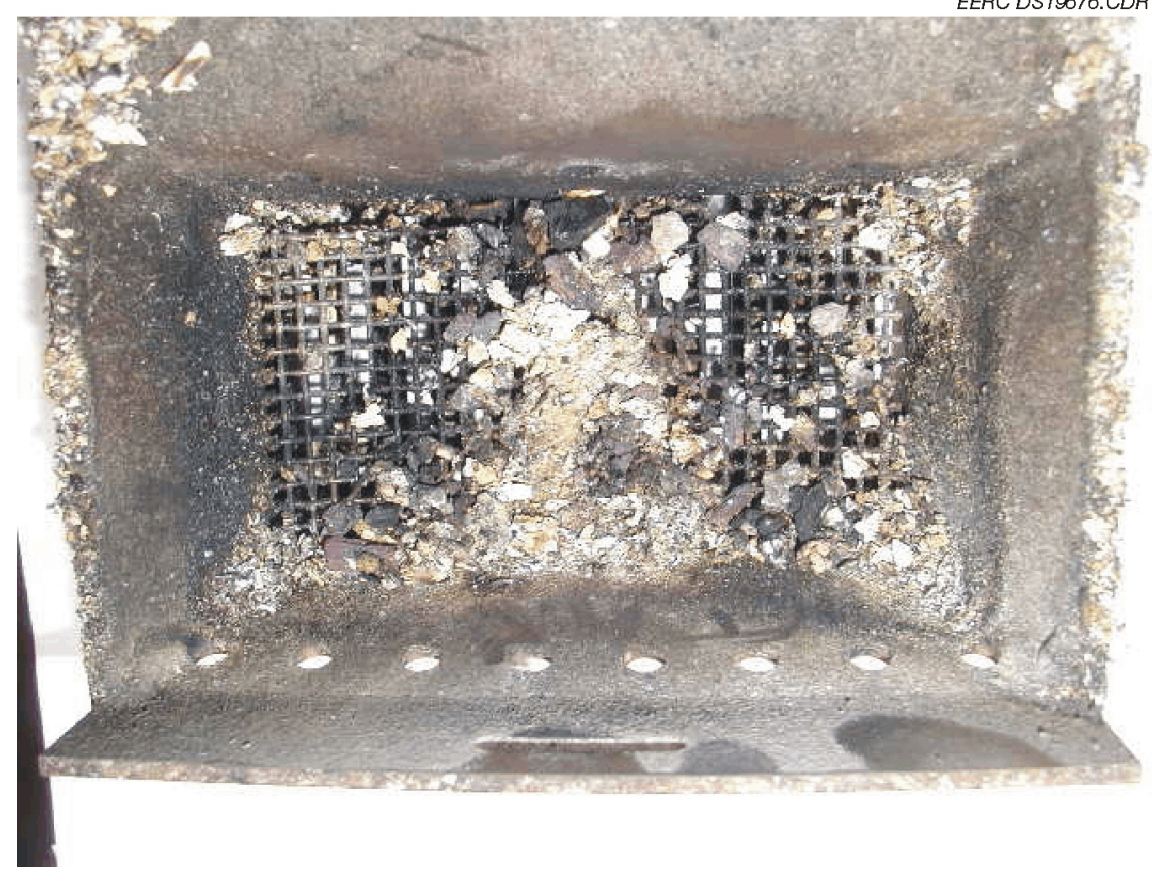


C-19. Cross Sections of Lignite and Lignite Blends 


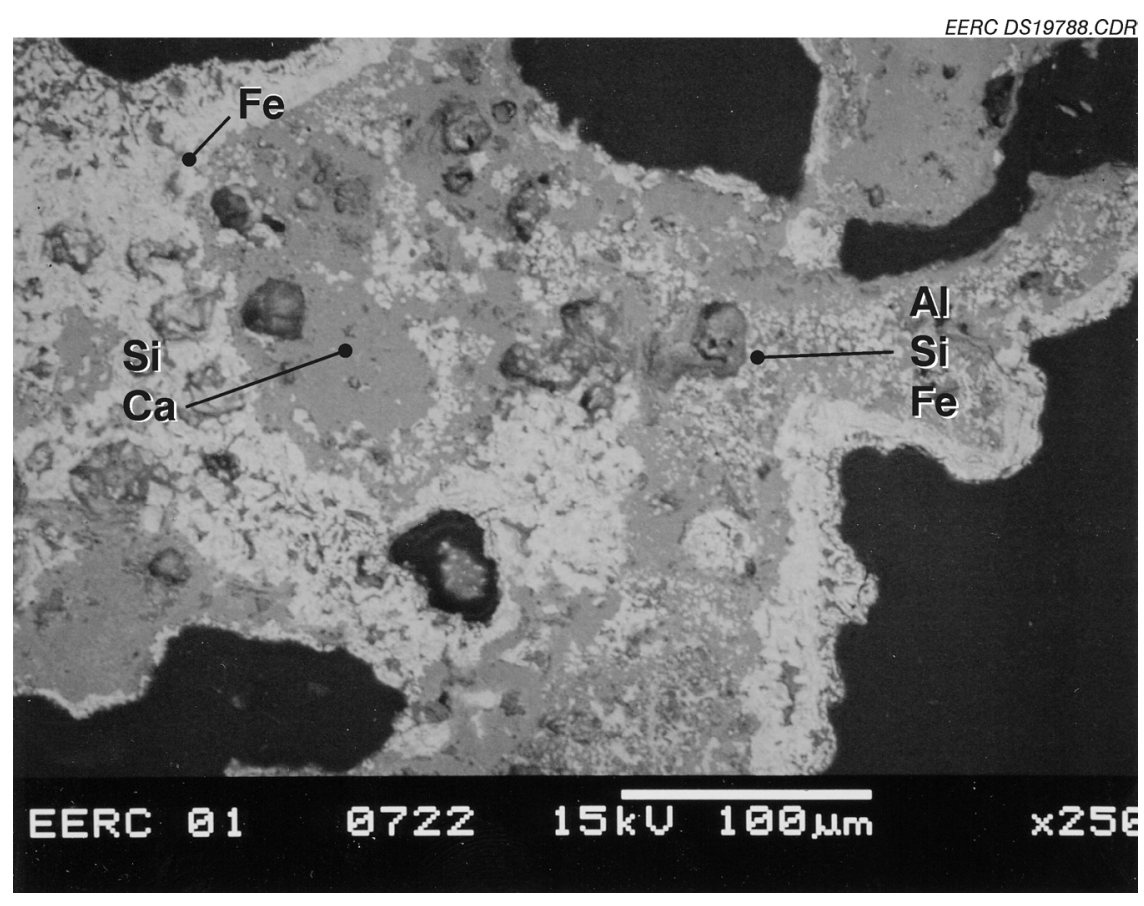

Figure C-19A. SEM image of 100\% lignite.

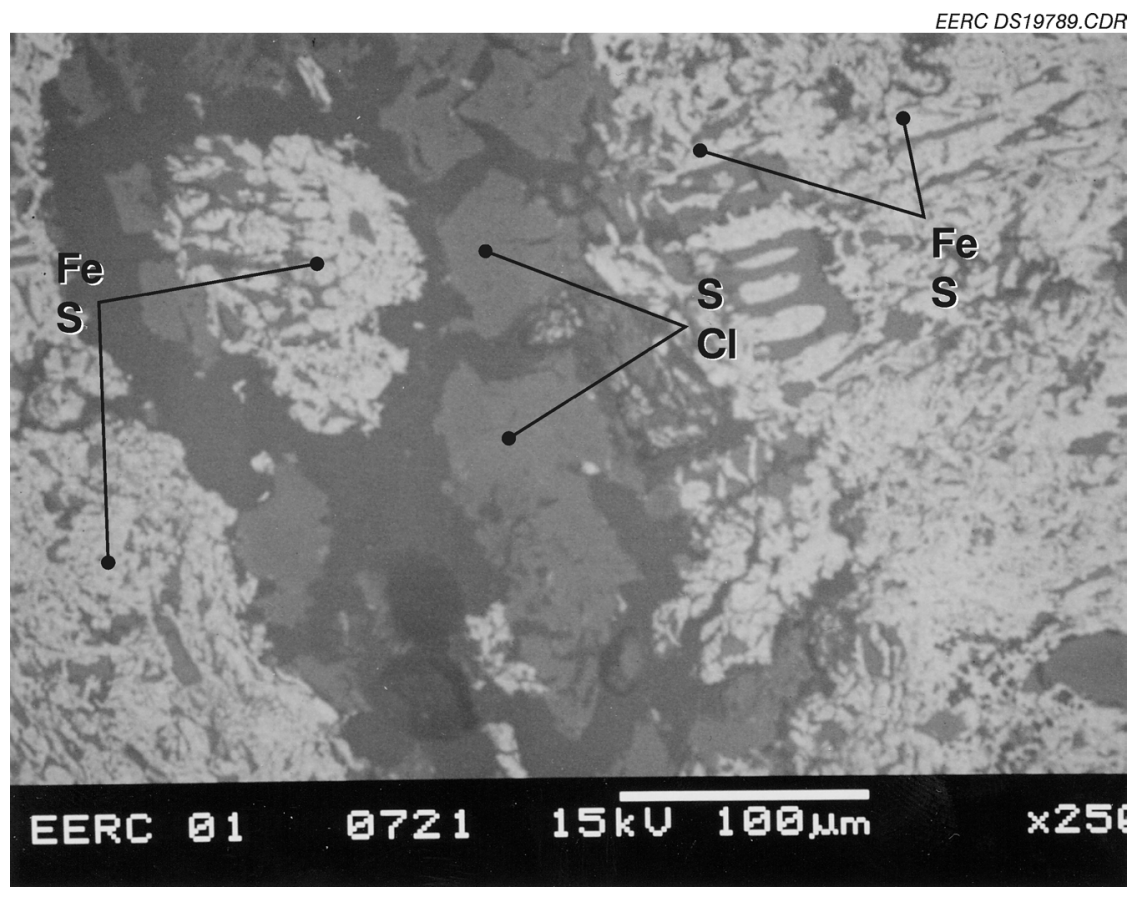

Figure C-19B. SEM image of 25\% lignite- $75 \%$ tree wood blend. 


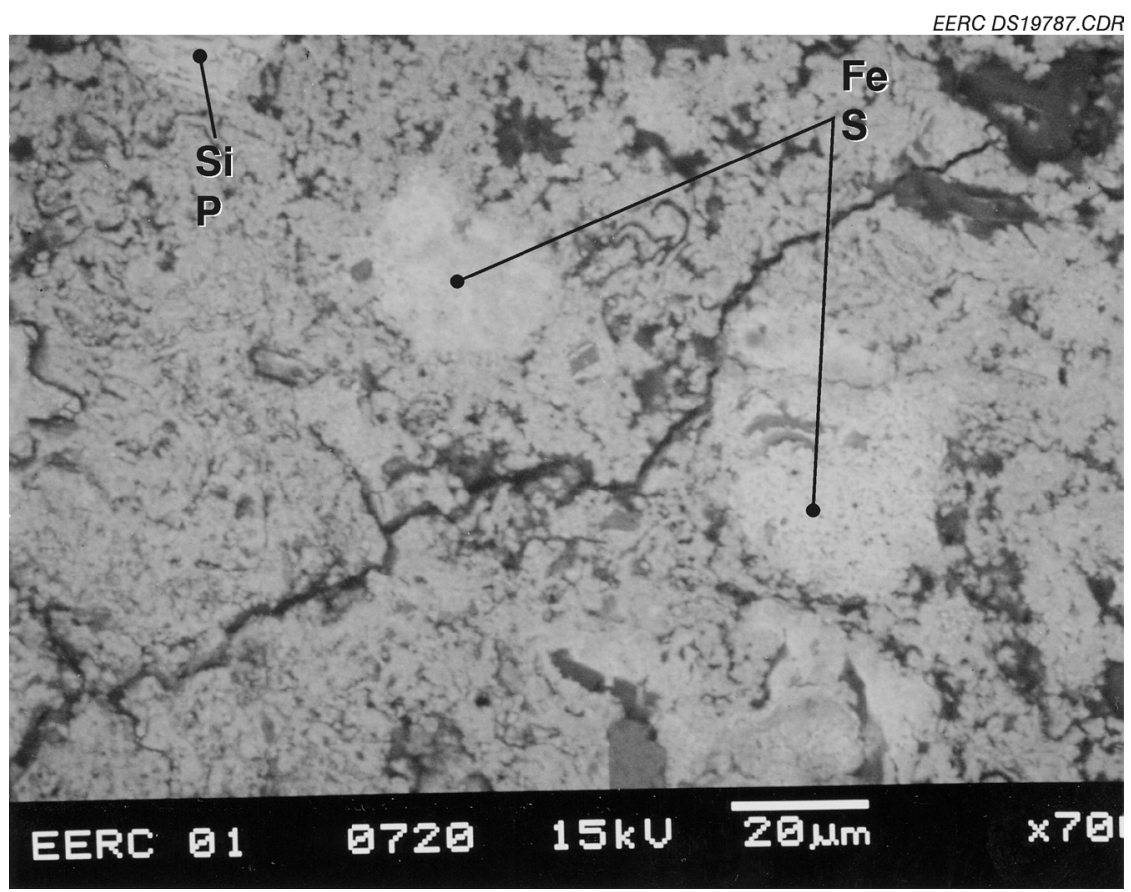

Figure C19-C. SEM image of 25\% lignite-75\% pallet wood blend. 
C-20. Comparison of Predicted and Actual Clinker Composition 
Table C-20. Comparison of Predicted and Actual Clinker Composition DMC 01/04/02

\begin{tabular}{|c|c|c|c|c|c|c|}
\hline $\begin{array}{l}\text { Oxide, } \\
\text { wt \% }\end{array}$ & $\begin{array}{r}\text { Predicted } \\
\text { Lignite }\end{array}$ & $\begin{array}{l}\text { Actual } \\
\text { Lignite } \\
\text { Clinker }\end{array}$ & $\begin{array}{r}\text { Predicted } \\
25 \% \text { Lignite } \\
75 \% \text { Tree Wood }\end{array}$ & $\begin{array}{r}\text { Actual } \\
25 \% \text { Lignite } \\
75 \% \text { Tree Wood }\end{array}$ & $\begin{array}{r}\text { Predicted } \\
25 \% \text { Lignite } \\
75 \% \text { Pallet Wood }\end{array}$ & $\begin{array}{r}\text { Actual } \\
25 \% \text { Lignite } \\
75 \% \text { Pallet Wood }\end{array}$ \\
\hline $\mathrm{SiO} 2$ & 19.8 & 6.6 & 13.7 & 10.0 & 21.7 & 14.1 \\
\hline $\mathrm{Al} 2 \mathrm{O} 3$ & 11.3 & 11.1 & 6.5 & 7.1 & 11.2 & 0.9 \\
\hline Fe2O3 & 10.7 & 33.9 & 6.5 & 18.4 & 10.5 & 23.6 \\
\hline TiO2 & 0.4 & 0.5 & 0.3 & 0.3 & 0.4 & 0.0 \\
\hline P2O5 & 0.1 & 0.1 & 4.0 & 0.0 & 0.4 & 5.7 \\
\hline $\mathrm{CaO}$ & 20.3 & 25.4 & 32.0 & 11.2 & 22.3 & 11.0 \\
\hline $\mathrm{MgO}$ & 5.6 & 1.7 & 6.9 & 1.6 & 5.7 & 1.1 \\
\hline $\mathrm{Na} 2 \mathrm{O}$ & 7.9 & 5.0 & 4.1 & 4.1 & 7.2 & 1.3 \\
\hline K2O & 0.8 & 0.2 & 12.9 & 1.9 & 2.5 & 0.3 \\
\hline $\mathrm{SO} 3$ & 23.2 & 15.4 & 13.3 & 45.4 & 18.2 & 42.0 \\
\hline
\end{tabular}

Sulfur-Free Basis

\begin{tabular}{|c|c|c|c|c|c|c|}
\hline $\mathrm{SiO} 2$ & 25.8 & 7.8 & 15.8 & 18.3 & 26.5 & 24.3 \\
\hline Al2O3 & 14.7 & 13.1 & 7.5 & 13.0 & 13.7 & 1.5 \\
\hline Fe2O3 & 13.9 & 40.1 & 7.5 & 33.8 & 12.9 & 40.7 \\
\hline TiO2 & 0.5 & 0.6 & 0.3 & 0.5 & 0.5 & 0.0 \\
\hline P2O5 & 0.1 & 0.1 & 4.6 & 0.1 & 0.5 & 9.9 \\
\hline $\mathrm{CaO}$ & 26.4 & 30.1 & 36.9 & 20.5 & 27.2 & 19.0 \\
\hline $\mathrm{MgO}$ & 7.3 & 2.0 & 8.0 & 2.9 & 6.9 & 1.8 \\
\hline $\mathrm{Na} 2 \mathrm{O}$ & 10.3 & 5.9 & 4.8 & 7.5 & 8.8 & 2.2 \\
\hline K2O & 1.0 & 0.3 & 14.8 & 3.5 & 3.0 & 0.6 \\
\hline
\end{tabular}


APPENDIX D

\section{ENERGY CALCULATIONS}




\begin{tabular}{|c|c|c|c|c|c|c|c|c|c|c|c|c|}
\hline \multicolumn{13}{|c|}{ Monthly Cases } \\
\hline Case & Stream & From & To & $\begin{array}{l}\text { Temperature } \\
{ }^{\circ} \mathrm{F}\end{array}$ & $\begin{array}{r}\text { Pressure } \\
\text { psia }\end{array}$ & $\begin{array}{l}\text { Flow } \\
\mathrm{lb} / \mathrm{hr}\end{array}$ & $\begin{array}{r}\text { Enthalpy } \\
\text { Btu/lb }\end{array}$ & Quality & \multicolumn{4}{|c|}{ Case Description and Calculation Summary } \\
\hline 1, JAN & S1 & CND1 & PUMP1 & 162 & 5 & 25,003 & 130 & $0 \%$ & \multicolumn{4}{|c|}{ System Performance for January Average Monthly Heat Load (based on billing) } \\
\hline 1, JAN & S13 & SP1 & ST1 & 388 & 215 & 8,348 & 1200 & $100 \%$ & Firing Rate & $37,775 \mathrm{kBtu} / \mathrm{hr}$ & CT Heat Rate & $37.8 \mathrm{lbs} / \mathrm{hr}-\mathrm{kW}$ \\
\hline 1, JAN & S14 & BOIL1 & SP1 & 388 & 215 & 25,003 & 1200 & $100 \%$ & Condensing Turbine Output & $441 \mathrm{~kW}$ & BPT Heat Rate & $190 \mathrm{lbs} / \mathrm{hr}-\mathrm{kW}$ \\
\hline 1, JAN & S15 & ST2 & CND1 & 162 & 5 & 16,655 & 1110 & $98 \%$ & Back Pressure Turbine Output & $44 \mathrm{~kW}$ & Parasitic Loss total & $6 \% \%$ of Output \\
\hline 1, JAN & S2 & SP1 & ST2 & 388 & 215 & 16,655 & 1200 & $100 \%$ & Total Power Output & $485 \mathrm{~kW}$ & & \\
\hline 1 , JAN & S3 & - & BOIL1 & 3018 & 15 & 37,900 & 808 & $0 \%$ & Pumping Requirement & $5.5 \mathrm{~kW}$ & & \\
\hline 1 , JAN & S4 & $\mathrm{HX1}$ & CND1 & 338 & 115 & 8,348 & 566 & $29 \%$ & Other Parasitic Loads & $24 \mathrm{~kW}$ & & \\
\hline 1, JAN & S5 & ST1 & $H X 1$ & 338 & 115 & 8,348 & 1182 & $99 \%$ & Net Power Out & $455 \mathrm{~kW}$ & & \\
\hline 1, JAN & S6 & PUMP1 & BOIL1 & 163 & 215 & 25,003 & 131 & $0 \%$ & Heat Load & $8,779 \mathrm{kBtu} / \mathrm{hr}$ & & \\
\hline 1, JAN & S7 & - & $H X 1$ & 100 & 10 & 5,000 & 68 & $0 \%$ & System Energy Efficiency & $27 \%$ & & \\
\hline 1, JAN & S8 & $H X 1$ & י & 193 & 10 & 5,000 & 1097 & $95 \%$ & & & & \\
\hline 1, JAN & s9 & BOIL1 & - & 485 & 15 & 37,900 & 103 & $0 \%$ & & & & \\
\hline 2, FEB & s1 & CND1 & PUMP1 & 162 & 5 & 25,003 & 130 & $0 \%$ & \multicolumn{4}{|c|}{ System Performance for February Average Monthly Heat Load (based on billing) } \\
\hline 2, FEB & $\mathrm{s} 13$ & SP1 & ST1 & 388 & 215 & 6,588 & 1200 & $100 \%$ & Firing Rate & $37,775 \mathrm{kBtu} / \mathrm{hr}$ & CT Heat Rate & $34.8 \mathrm{lbs} / \mathrm{hr}-\mathrm{kW}$ \\
\hline 2, FEB & S14 & BOIL1 & SP1 & 388 & 215 & 25,003 & 1200 & $100 \%$ & Condensing Turbine Output & $529 \mathrm{~kW}$ & BPT Heat Rate & $190 \mathrm{lbs} / \mathrm{hr}-\mathrm{kW}$ \\
\hline 2, FEB & S15 & ST2 & CND1 & 162 & 5 & 18,415 & 1102 & $97 \%$ & Back Pressure Turbine Output & $35 \mathrm{~kW}$ & Parasitic Loss total & $6 \% \%$ of Output \\
\hline 2, FEB & S2 & SP1 & ST2 & 388 & 215 & 18,415 & 1200 & $100 \%$ & Total Power Output & $564 \mathrm{~kW}$ & & \\
\hline 2 , FEB & s3 & - & BOIL1 & 3018 & 15 & 37,900 & 808 & $0 \%$ & Pumping Requirement & $5.5 \mathrm{~kW}$ & & \\
\hline 2, FEB & S4 & $H X 1$ & CND1 & 338 & 115 & 6,588 & 401 & $10 \%$ & Other Parasitic Loads & $28 \mathrm{~kW}$ & & \\
\hline 2, FEB & S5 & ST1 & $H X 1$ & 338 & 115 & 6,588 & 1182 & $99 \%$ & Net Power Out & $530 \mathrm{~kW}$ & & \\
\hline 2, FEB & s6 & PUMP1 & BOIL1 & 163 & 215 & 25,003 & 131 & $0 \%$ & Heat Load & $6,928 \mathrm{kBtu} / \mathrm{hr}$ & & \\
\hline 2, FEB & S7 & - & $\mathrm{HX} 1$ & 100 & 10 & 5,000 & 68 & $0 \%$ & System Energy Efficiency & $23 \%$ & & \\
\hline 2 , FEB & s8 & $H X 1$ & - & 193 & 10 & 5,000 & 1097 & $95 \%$ & & & & \\
\hline 2, FEB & s9 & BOIL1 & - & 485 & 15 & 37,900 & 103 & $0 \%$ & \multirow{2}{*}{\multicolumn{4}{|c|}{ System Performance for March Average Monthly Heat Load (based on billing) }} \\
\hline 3, MAR & s1 & CND1 & PUMP1 & 162 & 5 & 25,003 & 130 & $0 \%$ & & & & \\
\hline 3, MAR & $\mathrm{s} 13$ & $\mathrm{SP} 1$ & ST1 1 & 388 & 215 & 6,945 & 1200 & $100 \%$ & Firing Rate & $37,775 \mathrm{kBtu} / \mathrm{hr}$ & CT Heat Rate & $34.8 \mathrm{lbs} / \mathrm{hr}-\mathrm{kW}$ \\
\hline 3, MAR & S14 & BOIL1 & SP1 & 388 & 215 & 25,003 & 1200 & $100 \%$ & Condensing Turbine Output & $519 \mathrm{~kW}$ & BPT Heat Rate & $190 \mathrm{lbs} / \mathrm{hr}-\mathrm{kW}$ \\
\hline 3, MAR & $\mathrm{S} 15$ & ST2 & CND1 & 162 & 5 & 18,058 & 1102 & $97 \%$ & Back Pressure Turbine Output & $36 \mathrm{~kW}$ & Parasitic Loss total & $6 \% \%$ of Output \\
\hline 3, MAR & S2 & SP1 & ST2 & 388 & 215 & 18,058 & 1200 & $100 \%$ & Total Power Output & $555 \mathrm{~kW}$ & & \\
\hline 3, MAR & s3 & - & BOIL1 & 3018 & 15 & 37,900 & 808 & $0 \%$ & Pumping Requirement & $5.5 \mathrm{~kW}$ & & \\
\hline 3, MAR & S4 & $H X 1$ & CND1 & 338 & 115 & 6,945 & 441 & $15 \%$ & Other Parasitic Loads & $28 \mathrm{~kW}$ & & \\
\hline 3, MAR & S5 & ST1 & HX1 & 338 & 115 & 6,945 & 1182 & $99 \%$ & Net Power Out & $522 \mathrm{~kW}$ & & \\
\hline 3, MAR & S6 & PUMP1 & BOIL1 & 163 & 215 & 25,003 & 131 & $0 \%$ & Heat Load & $7,304 \mathrm{kBtu} / \mathrm{hr}$ & & \\
\hline 3, MAR & S7 & - & $\mathrm{HX1}$ & 100 & 10 & 5,000 & 68 & $0 \%$ & System Energy Efficiency & $24 \%$ & & \\
\hline 3, MAR & s8 & $H X 1$ & & 193 & 10 & 5,000 & 1097 & $95 \%$ & & & & \\
\hline 3, MAR & s9 & BOIL1 & - & 485 & 15 & 37,900 & 103 & $0 \%$ & & & & \\
\hline 4, APRIL & s1 & CND1 & PUMP1 & 162 & 5 & 25,003 & 130 & $0 \%$ & \multicolumn{4}{|c|}{ System Performance for April Average Monthly Heat Load (based on billing) } \\
\hline 4, APRIL & $\mathrm{S} 13$ & SP1 & ST1 & 388 & 215 & 3,216 & 1200 & $100 \%$ & Firing Rate & $37,775 \mathrm{kBtu} / \mathrm{hr}$ & СT Heat Rate & $33.1 \mathrm{lbs} / \mathrm{hr}-\mathrm{kW}$ \\
\hline 4, APRIL & S14 & BOIL1 & SP1 & 388 & 215 & 25,003 & 1200 & $100 \%$ & Condensing Turbine Output & $659 \mathrm{~kW}$ & BPT Heat Rate & $190 \mathrm{lbs} / \mathrm{hr}-\mathrm{kW}$ \\
\hline 4, APRIL & S15 & ST2 & CND1 & 162 & 5 & 21,787 & 1097 & $97 \%$ & Back Pressure Turbine Output & $17 \mathrm{~kW}$ & Parasitic Loss total & $6 \% \%$ of Output \\
\hline 4, APRIL & S2 & SP1 & ST2 & 388 & 215 & 21,787 & 1200 & $100 \%$ & Total Power Output & $676 \mathrm{~kW}$ & & \\
\hline 4, APRIL & s3 & - & BOIL1 & 3018 & 15 & 37,900 & 808 & $0 \%$ & Pumping Requirement & $5.5 \mathrm{~kW}$ & & \\
\hline 4, APRIL & S4 & $H X 1$ & CND1 & 211 & 115 & 3,216 & 180 & $0 \%$ & Other Parasitic Loads & $34 \mathrm{~kW}$ & & \\
\hline 4, APRIL & S5 & ST1 & $\mathrm{HX1}$ & 338 & 115 & 3,216 & 1182 & $99 \%$ & Net Power Out & $637 \mathrm{~kW}$ & & \\
\hline 4, APRIL & S6 & PUMP1 & BOIL1 & 163 & 215 & 25,003 & 131 & $0 \%$ & Heat Load & $3,382 \mathrm{kBtu} / \mathrm{hr}$ & & \\
\hline 4, APRIL & S7 & - & $\mathrm{HX} 1$ & 100 & 10 & 5,000 & 68 & $0 \%$ & System Energy Efficiency & $15 \%$ & & \\
\hline 4, APRIL & s8 & $H X 1$ & - & 193 & 10 & 5,000 & 713 & $56 \%$ & & & & \\
\hline 4, APRIL & s9 & BOIL1 & - & 485 & 15 & 37,900 & 103 & $0 \%$ & & & & \\
\hline
\end{tabular}




\begin{tabular}{|c|c|c|c|}
\hline 5, MAY & s1 & CND1 & PUMP1 \\
\hline 5, MAY & $\mathrm{S} 13$ & SP1 & $\mathrm{ST} 1$ \\
\hline 5, MAY & $\mathrm{S} 14$ & BOIL1 & SP1 \\
\hline 5, MAY & $\mathrm{S} 15$ & ST2 & CND1 \\
\hline 5, MAY & S2 & SP1 & ST2 \\
\hline 5, MAY & S3 & & BOIL1 \\
\hline 5, MAY & S4 & $\mathrm{HX} 1$ & CND1 \\
\hline 5, MAY & S5 & ST1 & $\mathrm{HX1}$ \\
\hline 5, MAY & S6 & PUMP1 & BOIL1 \\
\hline 5, MAY & S7 & . & $\mathrm{HX} 1$ \\
\hline 5, MAY & S8 & $\mathrm{HX} 1$ & 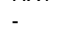 \\
\hline 5, MAY & s9 & BOIL1 & \\
\hline 6 , JUNE & $\mathrm{S} 1$ & CND1 & PUMP1 \\
\hline 6, JUNE & $\mathrm{S} 13$ & SP1 & ST1 \\
\hline 6, JUNE & $\mathrm{S} 14$ & BOIL1 & $\mathrm{SP} 1$ \\
\hline 6, JUNE & $\mathrm{S} 15$ & ST2 & CND1 \\
\hline 6, JUNE & S2 & SP1 & ST2 \\
\hline 6, JUNE & S3 & - & BOIL1 \\
\hline 6, JUNE & S4 & $\mathrm{HX} 1$ & CND1 \\
\hline 6, JUNE & S5 & $\mathrm{ST} 1$ & $\mathrm{HX} 1$ \\
\hline 6, JUNE & S6 & PUMP1 & BOIL1 \\
\hline 6, JUNE & S7 & & $\mathrm{HX} 1$ \\
\hline 6, JUNE & S8 & $\mathrm{HX} 1$ & 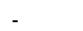 \\
\hline 6, JUNE & S9 & BOIL1 & - \\
\hline 7, JULY & $\mathrm{S} 1$ & CND1 & PUMP1 \\
\hline 7, JULY & $\mathrm{s} 13$ & SP1 & ST1 \\
\hline 7, JULY & $\mathrm{S} 14$ & BOIL1 & SP1 \\
\hline 7, JULY & $\mathrm{S} 15$ & ST2 & CND1 \\
\hline 7, JULY & S2 & SP1 & ST2 \\
\hline 7, JULY & S3 & & BOIL1 \\
\hline 7, JULY & S4 & $\mathrm{HX} 1$ & CND1 \\
\hline 7, JULY & S5 & ST1 & $\mathrm{HX1}$ \\
\hline 7, JULY & S6 & PUMP1 & BOIL1 \\
\hline 7, JULY & S7 & . & $\mathrm{HX} 1$ \\
\hline 7, JULY & S8 & $\mathrm{HX} 1$ & - \\
\hline 7, JULY & S9 & BOIL1 & 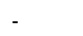 \\
\hline $8, A \cup G$ & $\mathrm{~S} 1$ & CND1 & PUMP1 \\
\hline 8, AUG & $\mathrm{S} 13$ & SP1 & ST1 \\
\hline $8, A \cup G$ & S14 & BOIL1 & SP1 \\
\hline 8, AUG & $\mathrm{S} 15$ & ST2 & CND1 \\
\hline 8, AUG & S2 & SP1 & ST2 \\
\hline 8, AUG & S3 & דו & BOIL1 \\
\hline 8, AUG & S4 & $\mathrm{HX} 1$ & CND1 \\
\hline 8, AUG & S5 & & $\mathrm{HX} 1$ \\
\hline 8, AUG & S6 & PUMP1 & BOIL1 \\
\hline $8, A \cup G$ & S7 & & $\mathrm{HX1}$ \\
\hline $8, \mathrm{AUG}$ & S8 & $\mathrm{HX} 1$ & - \\
\hline 8, AUG & s9 & BOIL1 & - \\
\hline
\end{tabular}

$\begin{array}{rrrrr}162 & 5 & 25,003 & 130 & 0 \% \\ 388 & 215 & 422 & 1200 & 100 \% \\ 388 & 215 & 25,003 & 1200 & 100 \% \\ 162 & 5 & 24,581 & 1092 & 96 \% \\ 388 & 215 & 24,581 & 1200 & 100 \% \\ 3018 & 15 & 37,900 & 808 & 0 \% \\ 211 & 115 & 422 & 180 & 0 \% \\ 338 & 115 & 422 & 1182 & 99 \% \\ 163 & 215 & 25,003 & 131 & 0 \% \\ 100 & 10 & 5,000 & 68 & 0 \% \\ 185 & 10 & 5,000 & 152 & 0 \% \\ 485 & 15 & 37,900 & 103 & 0 \% \\ 162 & 5 & 25,003 & 130 & 0 \% \\ 388 & 215 & 1,958 & 1200 & 100 \% \\ 388 & 215 & 25,003 & 1200 & 100 \% \\ 162 & 5 & 23,045 & 1094 & 96 \% \\ 388 & 215 & 23,045 & 1200 & 100 \% \\ 3018 & 15 & 37,900 & 808 & 0 \% \\ 211 & 115 & 1,958 & 180 & 0 \% \\ 338 & 115 & 1,958 & 1182 & 99 \% \\ 163 & 215 & 25,003 & 131 & 0 \% \\ 100 & 10 & 5,000 & 68 & 0 \% \\ 193 & 10 & 5,000 & 460 & 30 \% \\ 485 & 15 & 37,900 & 103 & 0 \% \\ 162 & 5 & 25,003 & 130 & 0 \% \\ 388 & 215 & 1,396 & 1200 & 100 \% \\ 388 & 215 & 25,003 & 1200 & 100 \% \\ 162 & 5 & 23,607 & 1092 & 96 \% \\ 388 & 215 & 23,607 & 1200 & 100 \% \\ 3018 & 15 & 37,900 & 808 & 0 \% \\ 211 & 115 & 1,396 & 180 & 0 \% \\ 338 & 115 & 1,396 & 1182 & 99 \% \\ 163 & 215 & 25,003 & 131 & 0 \% \\ 100 & 10 & 5,000 & 68 & 0 \% \\ 193 & 10 & 5,000 & 348 & 19 \% \\ 485 & 15 & 37,900 & 103 & 0 \% \\ 162 & 5 & 25,003 & 130 & 0 \% \\ 388 & 215 & 1,150 & 1200 & 100 \% \\ 388 & 215 & 25,003 & 1200 & 100 \% \\ 162 & 5 & 23,853 & 1092 & 96 \% \\ 388 & 215 & 23,853 & 1200 & 100 \% \\ 3018 & 15 & 37,900 & 808 & 0 \% \\ 211 & 115 & 1,150 & 180 & 0 \% \\ 338 & 115 & 1,150 & 1182 & 99 \% \\ 163 & 215 & 25,003 & 131 & 0 \% \\ 100 & 10 & 5,000 & 68 & 0 \% \\ 193 & 10 & 5,000 & 298 & 14 \% \\ 485 & 15 & 37,900 & 103 & 0 \% \\ & & & & \\ & & & \end{array}$

\begin{tabular}{|c|c|c|c|c|}
\hline \multicolumn{5}{|c|}{ System Performance for May Average Month Heat Load (based on billing) } \\
\hline Firing Rate & & $37,775 \mathrm{kBtu} / \mathrm{hr}$ & CT Heat Rate & $31.5 \mathrm{lbs} / \mathrm{hr}-\mathrm{kW}$ \\
\hline Condensing Turbine Output & & 781 kW & BPT Heat Rate & $190 \mathrm{lbs} / \mathrm{hr}-\mathrm{kW}$ \\
\hline Back Pressure Turbine Output & & $2 \mathrm{~kW}$ & Parasitic Loss total & $6 \% \%$ of Output \\
\hline Total Power Output & & $783 \mathrm{~kW}$ & & \\
\hline Pumping Requirement & & $5.5 \mathrm{~kW}$ & & \\
\hline Other Parasitic Loads & $5 \%$ & $39 \mathrm{~kW}$ & & \\
\hline Net Power Out & & $738 \mathrm{~kW}$ & & \\
\hline Heat Load & & $444 \mathrm{kBtu} / \mathrm{hr}$ & & \\
\hline System Energy Efficiency & & $8 \%$ & & \\
\hline \multicolumn{5}{|c|}{ System Performance for June Average Month Heat Load (based on billing) } \\
\hline Firing Rate & & $37,775 \mathrm{kBtu} / \mathrm{hr}$ & CT Heat Rate & $32.2 \mathrm{lbs} / \mathrm{hr}-\mathrm{kW}$ \\
\hline Condensing Turbine Output & & $715 \mathrm{~kW}$ & BPT Heat Rate & $190 \mathrm{lbs} / \mathrm{hr}-\mathrm{kW}$ \\
\hline Back Pressure Turbine Output & & $10 \mathrm{~kW}$ & Parasitic Loss total & $6 \% \%$ of Output \\
\hline Total Power Output & & $725 \mathrm{~kW}$ & & \\
\hline Pumping Requirement & & $5.5 \mathrm{~kW}$ & & \\
\hline Other Parasitic Loads & $5 \%$ & $36 \mathrm{~kW}$ & & \\
\hline Net Power Out & & $683 \mathrm{~kW}$ & & \\
\hline Heat Load & & $2,059 \mathrm{kBtu} / \mathrm{hr}$ & & \\
\hline System Energy Efficiency & & $12 \%$ & & \\
\hline \multicolumn{5}{|c|}{ System Performance for July Average Month Heat Load (based on billing) } \\
\hline Firing Rate & & $37,775 \mathrm{kBtu} / \mathrm{hr}$ & CT Heat Rate & $31.5 \mathrm{lbs} / \mathrm{hr}-\mathrm{kW}$ \\
\hline Condensing Turbine Output & & $750 \mathrm{~kW}$ & BPT Heat Rate & $190 \mathrm{lbs} / \mathrm{hr}-\mathrm{kW}$ \\
\hline Back Pressure Turbine Output & & $7 \mathrm{~kW}$ & Parasitic Loss total & $6 \% \%$ of Output \\
\hline Total Power Output & & $757 \mathrm{~kW}$ & & \\
\hline Pumping Requirement & & $5.5 \mathrm{~kW}$ & & \\
\hline Other Parasitic Loads & $5 \%$ & $38 \mathrm{~kW}$ & & \\
\hline Net Power Out & & $714 \mathrm{~kW}$ & & \\
\hline Heat Load & & $1,468 \mathrm{kBtu} / \mathrm{hr}$ & & \\
\hline System Energy Efficiency & & $10 \%$ & & \\
\hline \multicolumn{5}{|c|}{ System Performance for August Average Month Heat Load (based on billing) } \\
\hline Firing Rate & & $37,775 \mathrm{kBtu} / \mathrm{hr}$ & CT Heat Rate & $31.5 \mathrm{lbs} / \mathrm{hr}-\mathrm{kW}$ \\
\hline Condensing Turbine Output & & $758 \mathrm{~kW}$ & BPT Heat Rate & $190 \mathrm{lbs} / \mathrm{hr}-\mathrm{kW}$ \\
\hline Back Pressure Turbine Output & & $6 \mathrm{~kW}$ & Parasitic Loss total & $6 \% \%$ of Output \\
\hline Total Power Output & & $764 \mathrm{~kW}$ & & \\
\hline Pumping Requirement & & $5.5 \mathrm{~kW}$ & & \\
\hline Other Parasitic Loads & $5 \%$ & $38 \mathrm{~kW}$ & & \\
\hline Net Power Out & & $720 \mathrm{~kW}$ & & \\
\hline Heat Load & & $1,209 \mathrm{kBtu} / \mathrm{hr}$ & & \\
\hline System Energy Efficiency & & $10 \%$ & & \\
\hline
\end{tabular}




\begin{tabular}{|c|c|c|c|}
\hline 9, SEPT & S1 & CND1 & PUMP1 \\
\hline 9, SEPT & $\mathrm{S} 13$ & SP1 & ST1 \\
\hline 9, SEPT & S14 & BOIL1 & SP1 \\
\hline 9, SEPT & S15 & ST2 & CND1 \\
\hline 9, SEPT & S2 & SP1 & ST2 \\
\hline 9, SEPT & S3 & - & BOIL1 \\
\hline 9, SEPT & S4 & HX1 & CND1 \\
\hline 9, SEPT & S5 & ST1 & $\mathrm{HX1}$ \\
\hline 9, SEPT & S6 & PUMP1 & BOIL1 \\
\hline 9, SEPT & S7 & 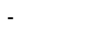 & $\mathrm{HX1}$ \\
\hline 9, SEPT & S8 & $\mathrm{HX1}$ & \\
\hline 9, SEPT & S9 & BOIL1 & \\
\hline 10, OCT & S1 & CND1 & PUMP1 \\
\hline 10, OCT & $\mathrm{S} 13$ & SP1 & ST1 \\
\hline 10, OCT & $\mathrm{S} 14$ & BOIL1 & SP1 \\
\hline 10, OCT & S15 & ST2 & CND1 \\
\hline 10, OCT & S2 & SP1 & ST2 \\
\hline 10, OCT & S3 & 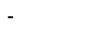 & BOIL1 \\
\hline 10, OCT & S4 & $H X 1$ & CND1 \\
\hline $10, \mathrm{OCT}$ & S5 & ST1 & $\mathrm{HX} 1$ \\
\hline $10, \mathrm{OCT}$ & S6 & PUMP1 & BOIL1 \\
\hline 10, OCT & S7 & 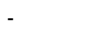 & $\mathrm{HX1}$ \\
\hline 10, OCT & S8 & $H X 1$ & 等 \\
\hline 10, OCT & S9 & BOIL1 & - \\
\hline 11, NOV & $\mathrm{S} 1$ & CND1 & PUMP1 \\
\hline 11, NOV & $\mathrm{S} 13$ & SP1 & ST1 \\
\hline 11, NOV & S14 & BOIL1 & SP1 \\
\hline $11, \mathrm{NOV}$ & S15 & ST2 & CND1 \\
\hline $11, \mathrm{NOV}$ & S2 & SP1 & ST2 \\
\hline 11 , NOV & S3 & se & BOIL1 \\
\hline 11 , NOV & S4 & HX1 & CND1 \\
\hline 11, NOV & S5 & ST1 & $\mathrm{HX1}$ \\
\hline 11 , NOV & S6 & PUMP1 & BOIL1 \\
\hline 11 , NOV & S7 & - & $\mathrm{HX1}$ \\
\hline 11, NOV & S8 & $\mathrm{HX1}$ & \\
\hline 11, NOV & S9 & BOIL1 & - \\
\hline 12, DEC & S1 & CND1 & PUMP1 \\
\hline $12, \mathrm{DEC}$ & $\mathrm{S} 13$ & SP1 & ST1 \\
\hline 12, DEC & $\mathrm{S} 14$ & BOIL1 & SP1 \\
\hline 12, DEC & S15 & ST2 & CND1 \\
\hline $12, \mathrm{DEC}$ & S2 & $\mathrm{SP} 1$ & ST2 \\
\hline $12, \mathrm{DEC}$ & S3 & - & BOIL1 \\
\hline 12, DEC & S4 & $\mathrm{HX1}$ & CND1 \\
\hline 12, DEC & S5 & ST1 & $\mathrm{HX} 1$ \\
\hline $12, \mathrm{DEC}$ & S6 & PUMP1 & BOIL1 \\
\hline 12, DEC & S7 & 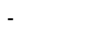 & $\mathrm{HX1}$ \\
\hline $12, \mathrm{DEC}$ & S8 & $\mathrm{HX} 1$ & \\
\hline 12, DEC & S9 & BOIL1 & \\
\hline
\end{tabular}

$\begin{array}{rrrrr}162 & 5 & 25,003 & 130 & 0 \% \\ 388 & 215 & 1,201 & 1200 & 100 \% \\ 388 & 215 & 25,003 & 1200 & 100 \% \\ 162 & 5 & 23,802 & 1092 & 96 \% \\ 388 & 215 & 23,802 & 1200 & 100 \% \\ 3018 & 15 & 37,900 & 808 & 0 \% \\ 211 & 115 & 1,201 & 180 & 0 \% \\ 338 & 115 & 1,201 & 1182 & 99 \% \\ 163 & 215 & 25,003 & 131 & 0 \% \\ 100 & 10 & 5,000 & 68 & 0 \% \\ 193 & 10 & 5,000 & 309 & 15 \% \\ 485 & 15 & 37,900 & 103 & 0 \% \\ 162 & 5 & 25,003 & 130 & 0 \% \\ 388 & 215 & 5,168 & 1200 & 100 \% \\ 388 & 215 & 25,003 & 1200 & 100 \% \\ 162 & 5 & 19,835 & 1097 & 97 \% \\ 388 & 215 & 19,835 & 1200 & 100 \% \\ 3018 & 15 & 37,900 & 808 & 0 \% \\ 218 & 115 & 5,168 & 186 & 0 \% \\ 338 & 115 & 5,168 & 1182 & 99 \% \\ 163 & 215 & 25,003 & 131 & 0 \% \\ 130 & 10 & 5,000 & 68 & 0 \% \\ 193 & 10 & 5,000 & 1097 & 95 \% \\ 485 & 15 & 37,900 & 103 & 0 \% \\ 162 & 5 & 25,003 & 130 & 0 \% \\ 388 & 215 & 8,733 & 1200 & 100 \% \\ 388 & 215 & 25,003 & 1200 & 100 \% \\ 162 & 5 & 16,270 & 1110 & 98 \% \\ 388 & 215 & 16,270 & 1200 & 100 \% \\ 3018 & 15 & 37,900 & 808 & 0 \% \\ 338 & 115 & 8,733 & 593 & 32 \% \\ 338 & 115 & 8,733 & 1182 & 99 \% \\ 163 & 215 & 25,003 & 131 & 0 \% \\ 100 & 10 & 5,000 & 68 & 0 \% \\ 193 & 10 & 5,000 & 1097 & 95 \% \\ 485 & 15 & 37,900 & 103 & 0 \% \\ 162 & 5 & 25,003 & 130 & 0 \% \\ 388 & 215 & 8,654 & 1200 & 100 \% \\ 388 & 215 & 25,003 & 1200 & 100 \% \\ 162 & 5 & 16,349 & 1110 & 98 \% \\ 388 & 215 & 16,349 & 1200 & 100 \% \\ 3018 & 15 & 37,900 & 808 & 0 \% \\ 338 & 115 & 8,654 & 588 & 32 \% \\ 338 & 115 & 8,654 & 1182 & 99 \% \\ 163 & 215 & 25,003 & 131 & 0 \% \\ 100 & 10 & 5,000 & 68 & 0 \% \\ 193 & 10 & 5,000 & 1097 & 95 \% \\ 485 & 15 & 37,900 & 103 & 0 \% \\ & & & & \\ & & & \end{array}$

\begin{tabular}{|c|c|c|c|c|}
\hline \multicolumn{5}{|c|}{ System Performance for September Average Month Heat Load (based on billing) } \\
\hline \multirow{2}{*}{\multicolumn{2}{|c|}{$\begin{array}{l}\text { Firing Rate } \\
\text { Condensing Turbine Output }\end{array}$}} & $37,775 \mathrm{kBtu} / \mathrm{hr}$ & CT Heat Rate & $31.5 \mathrm{lbs} / \mathrm{hr}-\mathrm{kW}$ \\
\hline & & 756 kW & BPT Heat Rate & $190 \mathrm{lbs} / \mathrm{hr}-\mathrm{kW}$ \\
\hline \multicolumn{2}{|l|}{$\begin{array}{l}\text { Condensing Turbine Output } \\
\text { Back Pressure Turbine Output }\end{array}$} & $6 \mathrm{~kW}$ & & \\
\hline \multicolumn{2}{|l|}{ Total Power Output } & $762 \mathrm{~kW}$ & & \\
\hline \multicolumn{2}{|l|}{ Pumping Requirement } & $5.5 \mathrm{~kW}$ & & \\
\hline \multirow{2}{*}{\multicolumn{2}{|c|}{$\begin{array}{l}\text { Other Parasitic Loads } \\
\text { Net Power Out }\end{array}$}} & $38 \mathrm{~kW}$ & & \\
\hline & & $719 \mathrm{~kW}$ & & \\
\hline \multicolumn{2}{|l|}{ Heat Load } & $1,263 \mathrm{kBtu} / \mathrm{hr}$ & & \\
\hline \multicolumn{2}{|l|}{ System Energy Efficiency } & $10 \%$ & & \\
\hline \multicolumn{5}{|c|}{ System Performance for October Average Month Heat Load (based on billing) } \\
\hline \multicolumn{2}{|l|}{$\begin{array}{l}\text { Firing Rate } \\
\text { Condensing Turbine Output }\end{array}$} & $37,775 \mathrm{kBtu} / \mathrm{hr}$ & CT Heat Rate & $33.1 \mathrm{lbs} / \mathrm{hr}-\mathrm{kW}$ \\
\hline \multirow{2}{*}{\multicolumn{2}{|c|}{$\begin{array}{l}\text { Condensing Turbine Output } \\
\text { Back Pressure Turbine Output }\end{array}$}} & $600 \mathrm{~kW}$ & BPT Heat Rate & $190 \mathrm{lbs} / \mathrm{hr}-\mathrm{kW}$ \\
\hline & & $27 \mathrm{~kW}$ & & \\
\hline \multicolumn{2}{|l|}{$\begin{array}{l}\text { Back Pressure Turbine Output } \\
\text { Total Power Output }\end{array}$} & $627 \mathrm{~kW}$ & & \\
\hline \multicolumn{2}{|l|}{ Pumping Requirement } & $5.5 \mathrm{~kW}$ & & \\
\hline \multicolumn{2}{|c|}{ Other Parasitic Loads $\quad 5 \%$} & $31 \mathrm{~kW}$ & & \\
\hline \multirow{2}{*}{\multicolumn{2}{|c|}{$\begin{array}{l}\text { Net Power Out } \\
\text { Heat Load }\end{array}$}} & $590 \mathrm{~kW}$ & & \\
\hline & & $5,435 \mathrm{kBtu} / \mathrm{hr}$ & & \\
\hline \multicolumn{2}{|l|}{ System Energy Efficiency } & $20 \%$ & & \\
\hline \multicolumn{5}{|c|}{ System Performance for November Average Month Heat Load (based on billing) } \\
\hline \multicolumn{2}{|c|}{ Firing Rate } & $37,775 \mathrm{kBtu} / \mathrm{hr}$ & CT Heat Rate & $37.8 \mathrm{lbs} / \mathrm{hr}-\mathrm{kW}$ \\
\hline \multicolumn{2}{|l|}{ Condensing Turbine Output } & $431 \mathrm{~kW}$ & BPT Heat Rate & $190 \mathrm{lbs} / \mathrm{hr}-\mathrm{kW}$ \\
\hline \multicolumn{2}{|l|}{ Back Pressure Turbine Output } & $46 \mathrm{~kW}$ & & \\
\hline \multicolumn{2}{|l|}{ Total Power Output } & $477 \mathrm{~kW}$ & & \\
\hline \multicolumn{2}{|l|}{ Pumping Requirement } & $5.5 \mathrm{~kW}$ & & \\
\hline \multicolumn{2}{|l|}{ Other Parasitic Loads } & $24 \mathrm{~kW}$ & & \\
\hline \multicolumn{2}{|l|}{ Net Power Out } & $447 \mathrm{~kW}$ & & \\
\hline \multirow{2}{*}{\multicolumn{2}{|c|}{$\begin{array}{l}\text { Heat Load } \\
\text { System Energy Efficiency }\end{array}$}} & $9,184 \mathrm{kBtu} / \mathrm{hr}$ & & \\
\hline & & $28 \%$ & & \\
\hline \multicolumn{5}{|c|}{ System Performance for December Average Month Heat Load (based on billing) } \\
\hline Firing Rate & & $37,775 \mathrm{kBtu} / \mathrm{hr}$ & CT Heat Rate & $37.8 \mathrm{lbs} / \mathrm{hr}-\mathrm{kW}$ \\
\hline Condensing Turbine Output & & $433 \mathrm{~kW}$ & BPT Heat Rate & $190 \mathrm{lbs} / \mathrm{hr}-\mathrm{kW}$ \\
\hline Back Pressure Turbine Output & & $45 \mathrm{~kW}$ & & \\
\hline Total Power Output & & $478 \mathrm{~kW}$ & & \\
\hline Pumping Requirement & & $5.5 \mathrm{~kW}$ & & \\
\hline Other Parasitic Loads & $5 \%$ & $24 \mathrm{~kW}$ & & \\
\hline Net Power Out & & $449 \mathrm{~kW}$ & & \\
\hline Heat Load & & $9,101 \mathrm{kBtu} / \mathrm{hr}$ & & \\
\hline System Energy Efficiency & & $28 \%$ & & \\
\hline
\end{tabular}

